Getalde of Bacter:

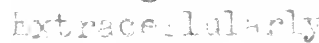

Ticks.

1942

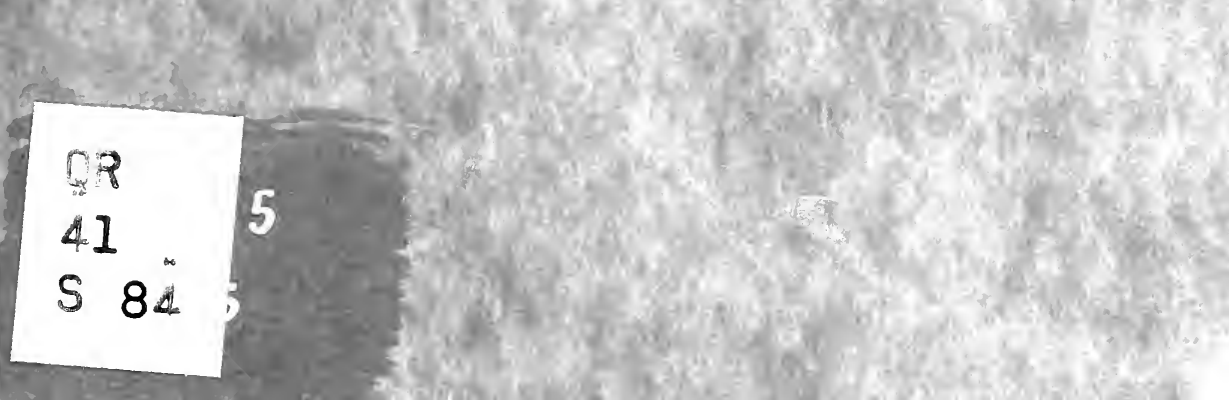


4 is; 5

$7,7,2$

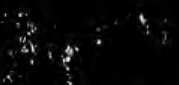

: : :

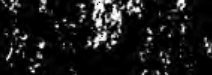

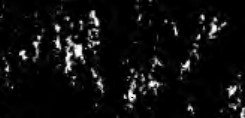

is 7

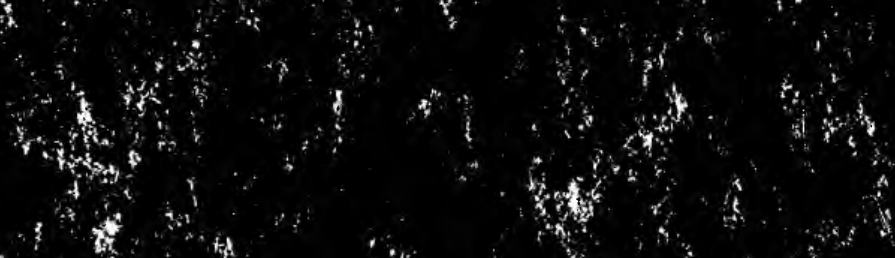

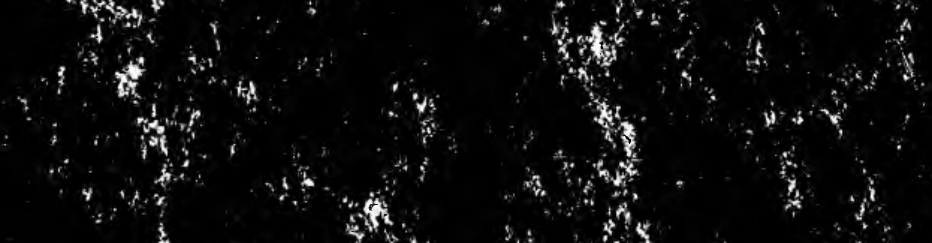

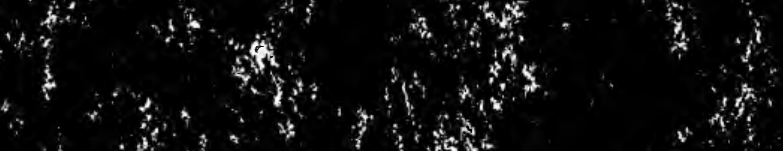

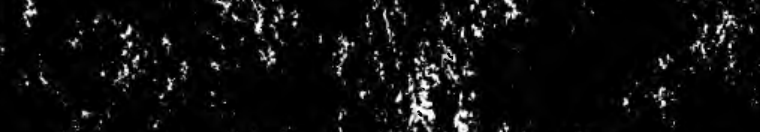

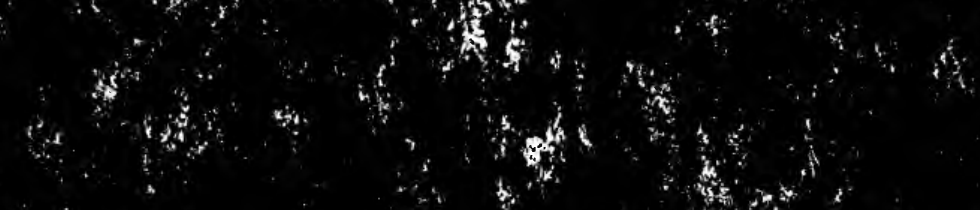

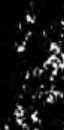

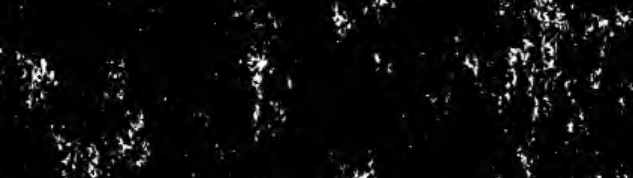

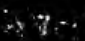

$$
\text { as }
$$

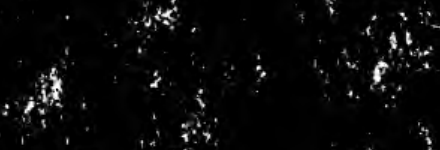

$\$$

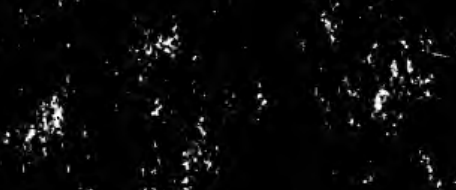




\title{
Catalogue of Bacteria Associated Extracellularly With Insects and Ticks
}

\author{
by
}

\author{
EDWARD A. STEINHAUS, Ph. D. \\ Associate Bacteriologist, U. S. Public Health Service \\ Rocky Mountain Laboratory \\ Hamilton, Montana
}

Copyright 1942 by

Edward A. Steinhaus

BURGESS PUBLISHING CO. 426 SO. SIXTH ST. MINNEAPOLIS, MINN. 



\section{FOREWORD}

This volume represents the first attempt toward bringing together in readily available form the essential data on the microbiology of insects and closely related arthropods. Research workers and others interested in this field have long been hampered not only by the widely scattered literature, much of it not easily accessible, but also by the varied terminology employed.

The phases of microbiology involved include the bacteria, rickettsiae, viruses, fungi and protozoa. The present publication covers only the extracellular bacteria, which is the largest group concerned. It is hoped that the author will be able to cover the intracellular bacteria and the other groups of microorganisms in future publications.

This catalogue will be of value as a reference work for entomologists, bacteriologists, and parasitologists generally and of particular value to research workers and others interested in more specialized fields such as those relating to the bacterial diseases of insects and the bacterial diseases transmissible directly or indirectly by insects and ticks to man, animals, and plants.

\section{R. R. PARKHR}

Director

Rocky Mountain Laboratory

Hamilton, Montana

April, 1942 


\section{TABLE OF CONTENTS}

Introduction

Resume of Pertinent Literature on Certain Relationships between Extracellular Bacteria and Insects and Ticks

External bacterial flora of insects. Bacterial flora of alimentary tract proper. Cecal bacteria. Fate of bacteria during metamorphosis. Transmission of bacteria from generation to generation. Bacteria and insect eggs. Variation of entomophytic bacteria. Bacteria as food for insects.

Bacteria and the physiology of insect digestion. Fermentation chambers. Bacteria as a source of vitamins. Bactericidal principles associated with ticks and insects. Surgical maggots.

Method of Using Catalogue

Class: Schizomycetes

Order: Actinomycetales

Family: Actinomycetaceae.

Genus: Leptotrichia

Family: Mycobacteriaceae

Genus: Corynebacterium

Genus: Mycobacterium

.

Order: Eubacteriales

Family: Bacillaceae

Genus: Bacillus

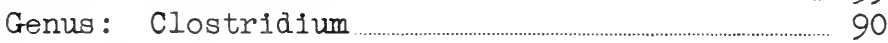

Family: Bacteriaceae ……................................................ 92

Genus: Achromobacter .......................................................... 92

Genus: Bacterium …................................................. 94

Genus: Flavobacterium …………_.......................... 115

Genus: Fusobacterium …….................................. 117

Family: Enterobacteriaceae _......................................

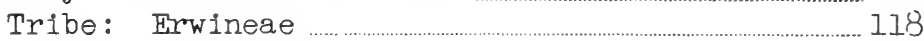

Genus: Erwinea $\quad 118$

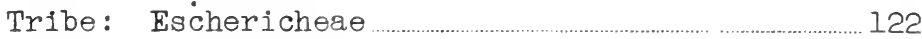

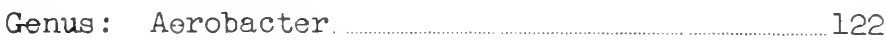

Genus: Escherichia .................................. 124

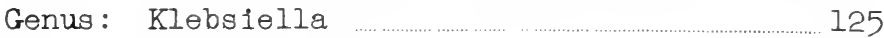

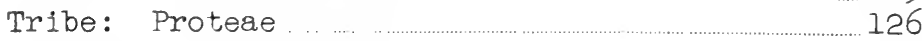

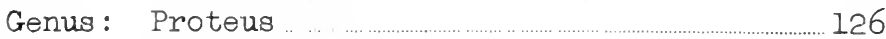

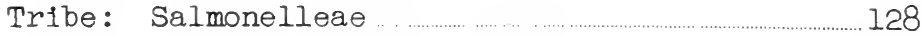

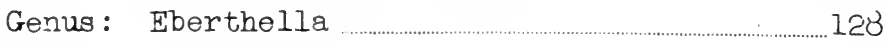

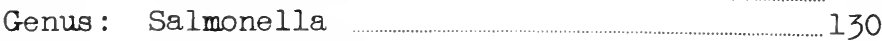

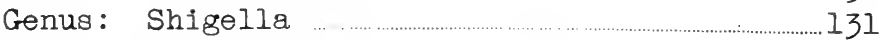

Tribe: Serrateae ..................................................................... 132

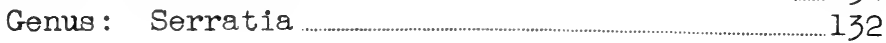


Family: Lactobacteriaceae.

Tribe: Streptococceae............................................................................. 136

Genus: Diplococcus ……................................................. 136

Genus: Streptococcus .......................................................... 138

Family: Micrococcaceae ......................................................................... 144

Genus: Micrococcus ............................................................ 144

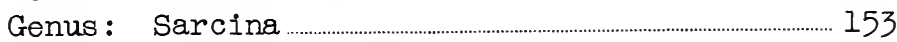

Genus: Staphylococcus ...................................................... 154

Family: Neisseriaceae ................................................................................ 157

Genus: Neisseria ....................................................................... 157

Genus: Veillonella ............................................................ 158

Family: Parvobacteriaceae ...................................................................... 158

Tribe: Brucelleae ....................................................................................... 158

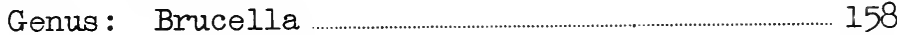

Tribe: Hemophileae …….............................................................. 159

Genus: Hemophilus …………........................................................ 159

Tribe: Pasteurelleae ............................................................................. 159

Genus: Pasteurella ........................................................................ 159

Family: Pseudomonadaceae .......................................................................... 168

Tribe: Pseudomonadeae ....................................................................... 168

Genus: Phytomonas ................................................................ 168

Genus: Pseudomonas ............................................................................ 172

Tribe: Spirilleae ..................................................................................... 174

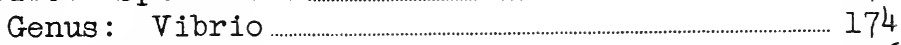

Family: Rhizobiaceae ……............................................................... 176

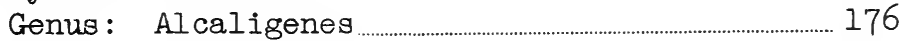

Genus: Chromobacterium ……............................................... 177

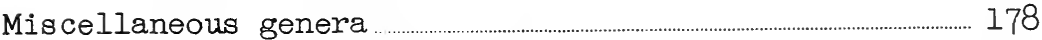

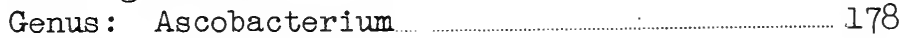

Genus: Coccobacillus ………...................................... 178

Genus: Diplobacillus _ _ _ . 184

Genus: Enterobacilius ............................................. 185

Genus: Enterococcus …….............................................. 185

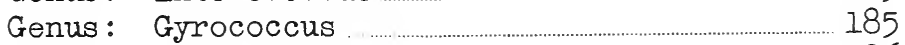

Genus: Leptotrix …................................................................... 186

Index to Authors

Index to Insects and Ticks

Index to Bacteria. 



\section{INTRODUCTION}

There has long been a need for an inventory and a systematic cataloguing of the bacteria associated with insects and ticks. Much of the confusion which today prevents a thorough understanding of the biologic relationships existing between bacteria and these arthropods might be avoided if investigators were furnished with a comprehensive list of the entomophytic bacteria and a statement concerning their arthropod relationships. To do this has been the chief objective of the present monograph.

A survey of the literature on bacteriologic-entomologic relationships indicates that there is an utter lack of conformity between the names given to certain bacteria by bacteriologists and those used by entomologists for the same bacterium. Entomologic literature is filled with names given to bacteria, references to which are not found anywhere in bacteriologic literature. Furthermore, there are numerous examples of the same bacterium being cited with different names by different authors. To add to the confusion, many investigators have not attempted to identify or to classify properly the bacteria they have isolated or found associated with insects. This has resulted in many taxonomic "ghosts" and ambizuities.

It would not be appropriate to discuss here ali systematic inconsistencies which appear in the literature on this subject. On the other hand, it is perhaps advisable to point out a few of the more serious causes of confusion in the hope that by focusing attention upon them now they may be avoided in the future.

One of the principle inconsistencies has been in the choice of the generic names. Although taxonomic procedures were not very definite during the early days of bacteriology, nevertheless, the errors made were out of all proportion to what they excusably might have been. Today, the rules of bacterial nomenclature have been fairly well established and are worthy of the attention of all those about to indulge in the naming of microorganisms. The indiscriminate use of the generic names Bacillus and Bacterium should definitely be discouraged. 
Present-day bacterial nomenclature reserves the genus Bacillus chiefly for the gram-positive, aerobic, sporeforming bacteria. In reviewing entomologic literature in particular, one repeatedly sees gram-negative, nonspore-forming short rods, and occasionally even cocci referred to by the generic name "Bacillus." Similarly, the generic name Bacterium has been used in referring to spore-forming bacilli.

The use of abbreviations, especially by early writers, also has been annoying. In many cases the only reference made to a generic name throughout an entire paper has been a single letter "B." , not indicating whether Bacterium or Bacillus is meant. Similarly, with the abbreviation "Bac." which one finds all too frequently. Equally confusing is the abbreviation "S." for Staphylococcus, Streptococcus, Sarcina, Serratia, Salmonelia, and Spirillum.

Although the use of trinomials is being largely discouraged by modern taxonomists, early workers even went so far as to use quadrinomials. Such names, given to bacteria remain of little taxonomic value except from an historic viewpoint.

It is especially unfortunate that the literature contains the names of so many microorganisms for which no adequate description has been published. In most instances this is due to the neglect, on the part of the discoverers, to make adequate morphologic, cultural and physiologic studies. It is not enough merely to observe that a microorganism is a short rod and then to give it a new specific name in the genus Bacterium. If an organism is worthy of a name it certainly should be worthy of an accurate, fairly complete description. Of course, some of the blame for this no doubt lies in the confusion still remaining in present-day bacteriai taxonomy. As stated by DeBach and Mcomiel: "The investigator sometimes does not know which

${ }^{1}$ DeBach, P. H., and Mcomie, W. A. Ann. Entomol. Soc. Amer., 1939, 32, 137-146.

of the characters studied is the more important. Often a valuable test is not performed because its importance is not realized, while a number of quite insignificant observations are laboriously made." On the other hand, if the investigator adheres to one or another of the more generally accepted methods of bacterial identification and classification, such as Bergey's Manual of Determinative Bacteriology, he is not likely to go far wrong. 
In using this catalogue, the reader will find a large number of strange bacterial names which are not listed in the latest (5th) edition of Bergey's Manual. It is unfortunate that so many undescribed species of bacteria exist. Regardless of the limitations of the available descriptions of the bacteria themselves, the importance of the role of these bacteria in the biologic relationships between them and insects should not be disregarded and overlooked. It is hoped that many of these bacteria will be reisolated and restudied so as to secure for them a place in the accepted list of bacterial species. Perhaps the bringing of these obscure names togethor in one publication along with the names of the well-known specles isolated from insects and ticks, will lead to a uniformity, an enlargement, and an acceleration of study and publication in this field, and will make for a more thorough coverage of the literature of this subject.

Since many of the interesting biologic relationships between arthropods and bacteri" in general could not be handled satisfactorily in catalogue form, they have been briefly discussed in the following section which summarizes the pertinent literature on these relationships. 
RESUME OF PERTINENT LITERATURE ON CERTAIN REIATIONSHIPS BETWEEN EXTRACELLULAR BACTERIA AND INSECTS AND TICKS.

There are approximately 250 known species of bacteria which have been found associated, in one way or another, with insects and ticks. This does not include the intracellular forms such as the rickettsiae and intracellular "symbiotes." A large number of the bacteria associated with these arthropods have never been completely described nor correctly classified. In general, however, the bacteria found in insects are not characteristically different from most bacteria. Limited studies have shown that the bacteria isolated from insects consist roughly of 40 to 50 per cent gram-negative short rods, 15 to 25 per cent gram-positive spore-forming rods, 15 to 25 per cent grampositive cocci, 10 to 12 per cent gram-positive short rods, and lower percentages of spirilla, "coccobacilli," and. other forms. Bacteria isolated from ticks appear to be predominantly cocci (50 per cent or more), with smaller numbers of non-spore-forming and spore-forming rods. Percentages such as the above will probably have to be modified as more complete studies on the flora of insects are made.

External bacterial flora of insects. The bacteria found on the external surface of insects are, for the most part, adventitious. This is especially the case with such insects as the housefly and cockroach which frequent areas of filth and decomposing organic matter. Such insects acquire a great and ever-changing variety of bacteria, many of which are of public health importance.

Due to peculiarities in body structure, such as the housefly with its bristles and sticky pads, many insects carry enormous numbers of microorganisms. Even in these cases many more bacteria are usually found inside than on the outside of the fly. For example, Yao, Yuan and Huie (1929) found an average of 3,683,000 bacteria (externally) per fly from the slum district of Peiping, China, and 1,941,000 per fly from the cleanest district. They found the inside of the flies to harbor from eight to ten times as many bacteria as the outside. Similarly, Torrey (1912) found the bacteria in the intestine of the housefly to be 8.6 times as numerous as those occurring on the external surface of the insect. Other insects, whose external body structure is not so complex, carry relatively few bacteria of any kind on their body' surfaces. It is interesting to note that bees, whose body structures are so well adapted 
for carrying pollen, have relatively few bacteria on their external surface. White (1906) found only three species (Bacillus A, Bacterium cyaneus, and Micrococcus $\underline{\mathrm{C}}$ ) on adult bees from normal apiaries.

Bacterial flora of alimentary tract proper. There is extreme variation in the size and structure of the alimentary tract of the different species of insects. In some species it is merely a tube extending from one end of the body to the other. In other species it is a highly complex structure with various pouches, ceca, and diverticula. In most insects the tract is longer than the body and possesses three chief divisions: the fore-intestine, the mid-intestine, and the hind-intestine. The fcre- and hind-intestine are invaginations of the body wall and their chitinous lining is continuous with the body wall cuticula. The mid-intestine develops from an entodermal tube, the mesenteron.

Although very little comparative work has been done on the bacterial flora of main divisions of the digestive tract of insects, Steinhaus (1941) reported that the milkweed bug, Oncopeltus fasciatus Say, has a different flora in its pylorum and rectum from that in the four stomachs which precede them. The predominant bacterium found in the pylorum and rectum was named Proteus recticolens, while in the four stomachs the flora consisted mainly of Proteus insecticolens. Eberthella insecticola and occasionally Streptococcus faecalis were found throughout the entire tract.

The bacterial flora of the digestive tract may vary quantitatively as well as qualitatively. While the tracts of some insects are packed with organisms others have been found to be sterile. In the honey bee, Hertig (1923) found the greater number of bacteria in the hindintestine, particularly the rectum, while very few both in numbers and variety were found in the ventriculus, except at times of food accumulation. Occasionally, when small sections of the wall and contents were inoculated into media, no growth at all resulted. Hertig explains the low bacterial content of the ventriculus as perhaps due to the fact that solid particles pass rapidly to the hind-intestine, and also to the fact that the contents of the ventriculus are at times rather acid. This might inhibit the multiplication of the bacteria. In the larvae of the olive fly, Dacus oleae, large numbers of bacteria are found in the mid-intestine, few in the hind- 
intestine, and none in the fore-intestine. In Tephritis conura, besides occuring in the intestinal lumen, bacteria are regularly found in the oesophagus as far as the region of the mouth opening and even in the proboscis.

Stammer, in a study of 37 species of trypetids, showed the presence of bacteria in all cases, but their manner of distribution varied with the stage and genus of the host. In the larvae and young adults the bacteria occurred diffusely or in clumps in the intestinal contents. In old adults they were always present in enormous numbers in the lumen of the intestine. In the case of Agriotes mancus, Melampy and MacLeod (1938) found the greatest number of bacteria in the hind-intestine. A similar condition in the petroleum fly, Psjlopa petroli, has been reported by Thorpe (1930).

The digestive tract of some arthropods, such as certain members of the blood-sucking group, is sterile. In other cases this sterility was localized to certain parts of the tract. An example of this regional sterility is found in blow-fly maggots used in the treatment of slow-healing lesions such as those in osteomyelitis. In the larvae of Lucilia sericata, for instance, the bacteria taken in with the food are destroyed in passing through the long, tubular stomach of the maggot. Bacteria may be found abundantly in the fore-stomach and occasionally in the intermediate area and the hind-stomach; none survive as far as the intestine (Robinson and Norwood, 1934).

Duncan (1926) found the gut contents of Cimex lectularius, Argas persicus, and Ornithodoros moubata to be consistently sterile. He quotes Breinl as finding the gut contents of lice to be invariably free of bacteria. Chapman (1924) examined the digestive tract of the confused flour beetle, Tribolium confusum Duv., and found no living organisms. Nuttall (Herms, 1939) found that the anthrax bacillus died in the stomach of the bedbug in 48 to 96 hours at $13^{\circ}$ to $17^{\circ} \mathrm{C}$. and in 24 to 28 hours at $37^{\circ} \mathrm{C}$., although the feces of the bugs contained living bacilli during the first 24 hours after feeding.

During the years following 1906 considerable interest was aroused in regard to the bacterial flora of the housefly (Musca domestica) as well as that of several species of cockroaches (Longfellow, 1913; Barber, 1914). Jackson (1907) found as many as 100,000 human fecal bacteria in a single fly, and recognized the fact that these bacteria 
might easily survive passage through the intestinal canal of the insect. Graham-Smith (1909) examined 148 flies caught in various parts of London and Cambridge, and 35 ( $24 \%$ ) possessed externally or internally, or both, bacteria belonging to the colon sroup. Later (1913), he reported that Serratia marcescens could be cultivated from the contents of the crop and intestine of the housefly in large numbers up tc 4 or 5 days after inoculation and survived in the intestine up to 18 days. Graham-Smith also states that although it seems to have been proven that the spores of Bacillus anthracis may survive after being ingested by fly larvae, most observers agree that such non-sporeforming pathogenic organisms as Eberthella typhosa, Salmonella enteritidis, and Shigella dysenteriae derived from cultures and added to the food of the larvae are not present in the flies which emerge, except under very special and highly artificial conditions. However, as stated elsewhere, Bacot (1911) reported that when the food of newly hatched larvae of Musca domestica was inoculated with a culture of Pseudomonas aeruginosa, viable bacteria remained in the gut during metamorphosis.

Torrey (1912) observed that flies examined up to the latter part of June were free from fecal bacteria of human origin and carried a homogeneous flora of coccal forms. During July and August, periods occurred when the flies examined possessed several mililions of bacteria, alternating with periods in which the number of bacteria was reduced to hundreds. Bacteria of the colon type was first encountered in abundance during the early part of July. Another example of seasonal incidence has been observed in the case of the bacteria producing soft rot of potatoes. In this case the bacieria pass the winter in the digestive tract of the puparia of Hylemyia cilicrura (Leach, 1933). Nicoll (1911), and Cox, Lewis, and $\overline{B l y n n}$ (1912) also studied the numbers and varieties of bacteria associated with the housefly, finding large numbers of the coliform type. (See also Hewitt, 1914).

Cecal Bacteria. In certain insects of the order Hemiptera peculiar sac-like appendages are found opening into the posterior end of the mid-intestine. These structures, called ceca or bacterial crypts, are of various shapes and sizes and always harbor enormous numbers of bacteria morphologically characteristic for the particular species of insect harboring them.

This bacteriologic-entomologic relationship was first studied in 1888 by Forbes (1892) during his investigations 
on contagious diseases of insects. He noted that certain appendages to the alimentary canal in members of the familieș Scutelleridae, Pentatomidae, and in some Lygaeidae and Coreidae contained large numbers of bacteria. In the Coreidae and Lygaeidae the cecal structures are present in one genus and absent in another. While the higher Hemiptera (Pentatomidae, Scutelleridae, etc.) invariably possess them, they are always absent in the lower Hemiptera. According to Forbes, the gastric pouches of grasshoppers, cockroaches, and carabid beetles do not commonly contajn bacteria. Earlier (1857) Leydig had apparently observed microorganisms in these ceca but he was not aware of their true nature.

It was not until 1914 that Glasgow undertook a detailed study of this relationship and brought out many interesting facts concerning it. Among other things, he observed that the bacteria from the different hosts vary a great deal in their morphology though they are constant for each individva.1 species of insect; that they range from minute coccusliks bacilli to hugh spirochete-like forms; and that these bacteria are apparently passed from generation to generation through the egg since they appear early in the alimentary tract of the developing embryo. This is one of the earliest recorded instances of the hereditary transmission of bacteria in insects. To study the constancy of the presence of bacteria in the ceca, Glasgow examined specimens of the harlequin cabbage bug, Murgantia histrionica, secured from widely separated points in the United States. In comparing the flora of these specimens he found that the peculiar large, spirochete-like forms were constantly present in the ceca regardless of whether the specimen examined "was from California or Maryland." FeN of the cecal bacteria could be grown on ordinary culture media, although those from Anasa tristis were cultured in nutrient broth.

The mid-intestine of these ceca-possessing insects is usually free of invading bacteria and protozoa commonly present in many related insects. It appears that the normal ceca-inhabiting bacteria inhibit the development or exclude these foreign organisms altogether. Glasgow believes that this is the chief function performed by the cecal bacteria in the life processes of the host. He assumes that the ceca merely provide a safe place for the multiplication of normal bacteria.

Kuskop (1924) lists 23 insects of the family Pentatomidae, 7 of the family Coreidae, and 4 of the family 
Lygaeidae which, she says, undoubtedly carry bacteria in their cecal appendages. She found the ceca to be as well filled with bacteria after the long period of winter rest as they were during the active summer season. Kuskop believes the bacteria play a symbiotic role in being essential in the physiology of the insect's digestion.

Fate of Bacteria During Metamorphosis. The fate of the bacteria harbored by the larva during the process of metamorphosis to the adult stage has not been studied thoroughly. Such knowledge would be particularly valuable from the standpoint of public health. For example, housefly larvae may become a reservoir for bacteria pathogenic to man. Should these bacteria survive metamorphosis and be disseminated by the adult, the chances of spreading disease are great. Also, in deciding what is the normal flora of an adult insect, one would have to consider adventitious bacteria that have been acquired not only by the imago itself, but by the larva as well.

Bacot (1911) found that pupae and imagines of Musca domestica bred from larvae infected with Pseudomonas aeruginosa under conditions which excluded the charcè of re-infection in the pupal or imaginal period, remained infected with the bacterium. Other authorities, however, are agreed that such non-spore-forming organisms as Eberthella typhosa, Salmonella enteritidis and Shigelia dysenteriae added to the food of fly larvae usually do not survive metamorphosis (Graham-Smith, 1913). Later, Bacot (1914) studied the bacteria of the alimentary canal of the flea during its metamorphosis and found that the alimentary canal of the flea larva may become "infected" with the following bacteria if they are mixed with its food: Pseudomonas aeruginosa, Salmonella enteritidis, Staphylococcus aureus, and $\underline{S}$. albus. These organisms may persist in the larval gut until the resting period of the larva in the cocoon, but there appears to be no satisfactory evidence that they can survive the pupal stage.

An interesting example of the survival of bacteria in an insect during metamorphosis has been shown by the work of Leach $(1931,1933)$ in the case of the bacterium causing potato blackleg, Erwinia carotovora, and the seed corn maggot, Hylemyia cilicrura. The maggots pick up the bacteria from their contaminated egg shells, from the soil, and probably from the surface of contaminated potato seed pieces. After 2 or 3 weeks' 
development in the seed pieces the maggots leave this abode, enter the soil, and pupate. In this manner the bacteria survive the winter in the digestive tract of the puparia. Besides Frwinia carotovora, other bacteria regularly pass uninjured through the intestinal tract of both larvae and flies and over-winter in the puparia and energe with the adult fly. The most common of these are: Pseudomonas fluoresence and Ps. nonliquefaciens. Leach (1933) fornd the bacteria survive in the puparium in three different locations: in the cast-out linings of the hindintestine, and in the lumen of the mid-intestine of the pupa. The bacteria found surviving in the fore- and hindintestines may be of several varieties since they are the ones that happen to be in these organs at the time of pupation. In the mid-intestine, on the other hand, the bacteria appear to be of one species resembling, but not identical to, Pseudomonas fluoresence. These bacteria become reduced to relatively small numbers during metamorphic histolysis but just before the fly emerges from the puparium they appear to increase rapidly. According to Leach, there appears to be a selective action on the bacteria surviving in the mid-intestine that is not operative on those surviving in the cast-off linings of the fore- and hind-intestines.

Relationships similar to those just described exist between Erwinia caratovora and the cabbage maggot, iylemyia brassicae. Phytomonas savastonoi, the cause of olive knot, is also known to survive in the puparium of the olive fly, Dacus oleae (Petri, 1910).

Transmission of Bacteria from Generation to Generation. Along with the discussion of the fate of bacteria during metamorphosis should be mentioned the phenomenon of transmission of bacteria from one generation to the next. Many instances of this process are known to occur with intracellular microorganisms.

An out.standing example of the perpetuation of extracellular bacteria through successive generation has been described by Petri (1909, 1910) in the case of Phytomonas savastonoi, the cause of olive knot, and the non-pathogenic bacterium, Ascobacterium luteum in the olive fly, Dacus oleae. These bacteria occur in the intestinal tract during all stages of the insect's development.

If one were to make a longitudinal section of the ovipositor of the olive fly, he would observe that the 
vagina and the anal tract unite at their posterior end forming a common opening. Peculiar sac-like evaginations, filled with hacteria, occur in the wall of the anal tract near the point of union and open into the lumen. A longitudinal slit in the membrane which separates the anal tract from the oviduct lies immediately opposite the opening of the evaginations. As the eggs pass along the vagina, the surface of each egg is pressed through this slit, against the openings. The bacteria contained within the evaginations are smeared over the surface of each egg from where they find their way through the micropyle into the egg. The bacteria are then incorporated into the embryologic development of the insect.

The larvae which hatch from the eggs possess four spherical ceca near the fore-part of the mid-intestine. These ceca contain the bacteria which may also be found throughout the lumen of the alimentary tract. During the pupal stage a bulb-like diverticulum branches off the esophagus just in front of the brain. (A similar structure has been observed by Dean $(1933,1935)$ in the apple maggot, Rhagoletis pomonella, but its possible relation to bacteria has not been determined.) The bacteria accumulate in this structure from which they later (in the adult fly) spread throughout the alimentary tract, including the anal sac-like evaginations. From this location the bacteria are transmitted to the next generation of eggs and thus they are perpetuated. According to Stammer (1929) and Allen and Riker (1932), similar bacterium-insect relationships exist in other species of Trypetidae. In Tephritis heiseri a similar aperture exists between the vagina and hind-intestine but the latter does not possess the claviform protrusions as does Dacus oleae. Instead, this area of the hind-intestine is differentiated into long drawnout channels which are narrowed in the direction of the opening. These are filled with bacteria which are applied to the eggs during oviposition. The freshly laid egg is covered with a layer of mucus in which the bacteria multiply until they enter the egg through the micropyle.

Among the ticks instances of generation to generation transmission of bacteria are not so well known. One important case in this regard, however, is the generation to generation and stage to stage transmission of Pasteurella tularensis in the Rocky Mountain wood tick, Dermacentor andersoni. This discovery was made by Parker and Spencer (1924). 
Bacteria and Insect Eggs. Atkin and Bacot (1917) and Bacot (1917) found that the greatest stimulus to the hatching of mosquito eggs (Stegomyia faciata) was the introduction into their environment of living yeasts or bacteria. The stimulus produced by killed cultures of bacteria and sterile watery extracts of brewer's yeast was more feeble, many of the eggs failing to hatch. Sterile filtrates of bacteria were less effective than killed cultures. The methods of experimentation were simple. Different species of living bacteria were introduced into tubes of sterile media, such as peptone water, in which the eggs had been lying dormant for 11 to 15, and in some cases, 39 days. Upon inoculation with the bacteria all eggs hatched within 18 hours. Atkin and Bacot explain this phenomenon by supposing that the stimulus is of the nature of a "scent" which penetrates to the larvae lying dormant within the egg shells, causing them to make vigorous movements which result in the uncapping of the egg.

On the other hand, Barber (1928) found "there was no indication that bacteria promoted hatching in either $\underline{\mathrm{C}}$. [Culex] quinquefasciatus or A. [Aedes] aegypti. Eggs hatched out in water or in clear sterile media as promptly as in contaminated cultures. In a few cases bacteria seemed to encourage the hatching of eggs of A. [Aedes] sollicitans, but they were surely not a necessary stimulus." Similarly, Hinman (1930 obtained results which were in direct opposition to those of Atkin and Bacot. Hinman "repeatedly found that eggs of this mosquito [Aedes aegypti] (and also other species) hatched apparently as rapidly in sterile as in contaminated media."

Some of the differences of opinion on this phenomenon were reconciled by Rozeboom (1934), who found that a great deal depends on the age and condition of the egg. Of 240 old, dry eggs (Aedes aegypti) only four hatched in sterile media, whereas $\overline{204}$ hatched within two days following inoculation of the media with bacteria. Of fresh, moist eggs, 35 per cent hatched in distilled water, and 82 per cent in water contaminated with bacteria.

More recently Gjullin, Yates, and Stage (1939) founc that tap-water infusions of dry cottonwood leaves, willow leaves and grass gave consistently larger hatches of Aedes vexans and Aedes aldrichi eggs than either tap or river water alone. They concluded that the amino acids and proteins present in vegetation may be the stimulants which cause the eggs to hatch when flooded in nature. 
In this connection an interesting observation of Hinman's (1932) should be mentioned. This worker found viable bacteria within the eggs of Aedes aegypti and other mosquitoes. By both cultural and microscopic examinations he found cocci, bacilli, and yeast within the mosquito ova. The most common type of bacteria found in sections was the coccus, with bacilli rarely being encountered. As Hinman points out, probably only a relatively small percentage of eggs actually contain microorganisms.

Variation of Entomophytic Bacteria. It is well known that bacterial cells may change in shape, size, and structure. Some of these changes are due to changes in environment and are not inherited. In other cases the changes are more stable and are the result of artificial selection, and in still other instances distinct mutationlike changes occur.

Into which of these categories fall the various instances of variation among entomophytic bacteria is difficult to say. Besides the occurrence of bacterial variation within the insect host itself, this phenomenon has also been observed in artificial cultures isolated from the host and in other insects artificially inoculated with the bacterium concerned.

As in the early history of bacteriology, variation of bacterial species in irsects has caused considerable trouble and controversy among investigators. Typical of this is the case of Bacillus alvei, the cause of European foulbrood of bees. Cheshire and Cheyne (1885) were the first to isolate this organism as the etio'logic agent of this disease. Maassen (1907) believed that either Bacillus alvei or Streptococcus apis was the cause. White (1912, 1920a, 1920b) was unable to produce typical European foulbrood with Bacillus alvei, Streptococcus apis, or Bacterium (Achromobacter) eurydice and concluded that a new species, Bacillus pluton, was the real cause. Burnside (1924) attempted to bring some order out of this confusion by suggesting that Bacillus pluton, Streptococcus apis, and Achromobacter eurydice are variants or stages in the life history of Bacillus alvei. He found that "Bacillus alvei is capable of morphological, cultural, and biological transformation and is also capable of stabilization, at least temporarily, as a sporogenic rod, an asporogenic rod resembling Bacterium eurydice, or as a coccoid form resembling Bacillus pluton. 
Paillot (1933) has found that the majority of coccobacilli isolated from insects change their form more or less according to the insect into which they are inoculated. The bacteria may undergo such minor changes as a slight elongation of the cell or the changes may be of a more striking nature. Such variations have been observed with Bacterium pieris liquefaciens alpha, Bacterium melolonthae Iiquefaciens gamma, and Bacterium lymantricola adiposus. For instance Bacterium pieris liquefaciens alpha is in the form of coccobacilli in the blood of the larvae of the cabbage butterly, Pieris brassicae. In the blood of the larvae of Vanessa urticae, there is no appreciable difference. In the larvae of Vanessa polychloros and Euproctis chrysorrhoea the cells are considerably longer than in the first two species. In the blood of Lymantria dispar, however, the elongation is so great that the bacteria lose all aspects of coccobacilli and are transformed into sinuous filaments which may attain the length of 40 or 50 nicrons. When inoculated back into the general cavity of the Pieris brassicae larvae the cells return to their normal form.

Bacterium melolonthae liquefaciens gamma, which usually appears in the form of a coccobacillus, becomes elongated and thicker when inoculated into the larvae of the gypsy moth, Porthetria dispar. As the infection advances, a certain number of the bacteria show one or two median or polar swellings. According to Paillot, these swellings later become detached from the bacterial elongations and float freely in the blood though they are not actively motile like the bacilli from which they originated. These forms resemble small true cells, possessing a central portion which may be taken for a true nucleus since it takes nuclear stains. When the insect dies these forms gradually disappear.

Similar "growth forms" have been observed in certain strains of Bacterium lymantricola adiposus inoculated into Porthetria dispar. In this case they originate from an enlargement of the central portion of the bacterium. These enlargements continue to elongate and often give rise to secondary elongations, the whole thing resembling a kind of mycelium. In old strains the bacteria and "growth forms" may be seen to possess a large central vacuole which disappears when the elongations re-absorb themselves into new rounded forms which float freely in the blood. Similar forms of this bacterium have been described as developing in the blood of the larvae of Agrotis segetum. 
Such forms of variation have also been observed in the case of Bacterium pieris liquefaciens alpha.

Paillot theorizes that these "growth forms" probably represent a degenerate stage of the bacteria. The incrcased ability of the organisms to give rise to these forms corresponded to a diminution in their original cirulence for the insects. This hypothesis is similar to that which, according to some workers, characterizes the symbiotes of aphids. In the absence of detailed work in this field, one wonders what types of variation might occur by the passage through insects of some of the better known bacteria not usually found in association with insects. One indication of such interesting possibilities is that afforded by the work of Lal, Ghosal, and Mukherji (1939) who found that certain morphologic, metabolic and chemical changes occurred in strains of Vibrio comma passed through house flies (Musca domestica).

Involution forms occurring on artificial media frequently arise in cultures of bacteria isolated from insects. Bacillus liparis is normally a slightly elongated, straight, or slightly bent rod, but when cultivated on carbohydrate media such as levulose agar, huge forms, swollen in clubs at one or both of their extremities, may be observed. These forms resemble very closely certain involution forms cf the diphtheria bacillus.

Bacterium neurotomae, isolated from Neurotoma nemoralis, appears in the blood of various insects in the form of elongated but rarely filamentous rods. However, in young cultures on agar some of the celis swell greatly and become more or less rounded. In the central part of these rounded cells is consolidated the chromatophilic substance and the whole aspect is one of true nucleated cells. According to Paillot, however, they are without vitality and rapidly degenerate.

From the Iyreman cicada, Tibicen Iinnei, Steinhaus (1941) isolated a gram-positive bacterium (Bacterium mutabile) which normally has the form of a short rod. In fluid media, such as tryptophane broth, bizarre, slightly branched forms appear.

\section{The Role of Bacteria in the Nutrition of Insects}

Inasmuch as most insects harbor large numbers of bacteria within their digestive tracts, it is apparent that these microorganisms may exert a profound effect 
upon insect physiology and nutrition. Despite this obvious possibility, very little investigation has been made on the actual function of bacteria and other microorganisms in such processes.

Bacteria as food. Besides the possibility of being related to the food habits of an insect and aiding in its digestive functions, bacteria may serve as food.

Mitchell (1907) was one of the first to express the belief that the "wriggler" of Stegomyia fasciata is preeminently a bacteria-feeder, because the larvae develop rapidly in water contaminated with sewage. In later years her belief was supported by the work of Bacot (1916), Atkin and Bacot (1917), Barber (1928), Rozeboom (1935) and others. In Bacot's report the suggestion that the bacteria served as food for the mosquito larvae was based on the clearing action the latter displayed in water, originally turbid from its enormous bacterial content, in conjunction with the ract that the gut contents of larvae taken from this water showed relatively few bacteria. He attributed the scarcity of bacteria to their being rapidly digested. Barber (1927, 1928) found that algae alone, bacteria alone, or infusoria alone may serve as a sufficient source of food for Anopheles larvae but that a combination of bacteria with infusoria or with algae appeared to afford the best conditions for the growth of Culex quinquefasciatus and of Aedes aegypti.

From the intestinal examination of over 600 mosquito larvae, Hinman (1930) concluded that the larvae ingest any material small enough to be taken in through the mouth. A considerable amount of this material appears to pass unchanged through the alimentary canal. Whereas larvae failed to develop in sterile, synthetic media or in autoclaved water taken from normal breeding places, the addition of certain types of bacteria to such water made it a suitable medium for complete larval development. Hinman (1933) later demonstrated the existence of a factor in bacteria which stimulated the growth of mosquito larvae, but he was unable to extract this vitamin-like substance from the bacteria with any regularity. Filtrates from these cultures failed to stimulate development. In 1935, Rozeboom studied the problem and concluded that bacteria, to a certain extent, can be utilized as food by mosquito larvae though all kinds of bacteria are not equally suitable as food for mosquito larvae. "Environmental bacteria," associated with the natural breeding places of mosquitoes, 
proved to support the best development of the larvae when bacteria were the only source of food. Sarcina lutea was of little value, while Escherichia coli, Bacillus subtilis, Bacillus mycoides, Aerobacter aerogenes, and Pseudomonas fluorescens were of equal value. In media inoculated with Pseudomonas (pyocyaneus) aeruginosa the toxic products of this organism rapidly killed the larvae. Rozeboom's attempts to grow mosquito larvae in the absence of bacteria were unsuccessful. Trager (1935a), b) obtained normal development of the larvae of Aedes aegypti in the absence of living microorganisms. He used a meäium consisting of a standard autoclaved protein-free liver extract with autoclaved yeast. He demonstrated that the lervae require two accessory food substances. One is present in yeast and aqueous yeast extracts, egs white, and wheat. It is heat-and alkali-stable and is not adsorbed by fuller's earth. The other is present in large amounts in purified. liver extracts rich in the anti-pernicious anemia principle. It is heat-stable but cannot withstand the action of alkalis. In a slightly acid solution it is almost comoletely adsorbed by fuller's earth. Interestingly enough, It has been found. (Trager, Miller, and Rhoads, 1938) that a substance, possibly flavine or a flavine compound, occurs in extracts prepared from urine of normal persons or patients with aplastic anemia or leukemia which enhances the growth of larvae of Aedes aegypti.

A relationship similar to that of the mosquito larvae in contaiminated water is suggested by von Wolzogen Kühr (1932) with the larvae of Chironomus plumosus which frequents sandfilters in the summer. This was attributed to the presence in the filters of Pseudomonas fermentans upon which the Iarvae supposealy fed. A similar situation was described by Dyson and Lloya (1933) in sewage beds.

One of the first to advance the idea that bacteria are indispensable to the growth of certain insects was Bogdanow (1906) who found that the larvae of Calliphora vomitoria fail to develop in the absence of microorganisms. Later (1908) he stated that the larvae require a definite and fairly simple bacterial flora. Sterile larvae on sterile food never developed normally, although some of them reached the pupal stage. Weinland (1907), however, showed that the larvae of Calliphora are able to digest meat without the assistance of bacteria. Bogdanow also found that larvae of the house fly, Musca domestica, can be bred on starch paste or gelatin, but only in the presence of molds and bacteria. Wollman (192l) reported that microbe-free cultures of files can be maintained indefinitely, as can 
also similar cultures of the moth Galleria melonella. The work of Glaser (1924) showed that the growing larvae of flies were dependent on certain accessory growth factors which may be obtained from bacteria and yeasts, but that microorganisms and their activities are not absolutely essential to the normal growth, development and longevity of flies. Later (1938) he developed a method whereby house flies could be raised in sterile culture, free from microorganisms. Baumberger (1919) reported that the larvae of the fly Desmometopam-nigrum Zett. are probably dependent on microorganisms and that the larvae of the house fly very probably feed on microorganisms. Trypetidae larvae can develop only when microorganisms are present, according to stammer (1929).

Bacteria and the physiology of insect digestion. Considerable evidence has been advanced that bacteria may play a greater role in the nutrition of insects than merely serving as food. Bacteria are capable of producing proteolytic, lipolytic, saccharolytic, amylitic and other enzymes which no doubt exert considerable influence on the digestive processes of the insect harboring them.

The best known examples of such a relationship are those concerned with the intestinal flagellates which take an active part in the digestion of cellulose in the gut of the termite and in the wood-feeding roach Cryptocercus. However, we shall limit ourselves here to a brief discussion of the bacteria which maintain similar relationships.

Petri (1905) was one of the earliest to assign to the bacteria a definite digestive role. The bacteria constantly present in the ceca of the olive fruit fly (Dacus oleae) were found to produce lipase. It was suggested that the activity of the bacteria in the digestion of fats must be very important for the larva which feeds on the olive, a fruit rich in fats. In a later paper (1910), he asserts that partial digestion of the oil might be possible without the aid of bacteria, since many larvae living on seeds rich in oil do not possess intestinal bacteria. Bogdanow (1906) believed that the formation of ammonia during larval development of Calliphora vomitoria is not a characteristic of protein digestion by the larvae but probably a result of bacterial activity. Weinland (1907), on the other hand, insisted that the ammonia is the result of larval metabolism. Wollman (1911, 1921) indicates that Weinland was mistaken as no ammonia is produced by sterile larvae and its production, therefore, must be due to microorganisms. 
Weinland (1908) observed further that bacteria take no part in the process of fat formation in the larvae. Guyenot (1906, 1907) found that muscid larvae (mostly those ol Lucilia) are unable to produce any digestive ferments which liquely meat. He believed that this is accomplished by bacteria. On the other hand, Wollman (1921) claims that aseptically bred larvae liquefy gelatin, which indicates that they produce some proteolytic ferments.

One may expect to find almost any saccharolytic enzyme in the digestive tracts of insects if one considers the variety which may arise from the bacteria they harbor. The fermentative ability of bacteria isolated from the alimentary tracts of insects and ticks varies from almost none to at least 25 or 30 carbohydrates. It is evident that in the insect the bacteria would not be called upon to produce most of these enzymes unless the appropriate substrates vere inciuded in the arthropod's lood, In the case of the cattle grub, Hypoderna lineatum, Simmons (1939) found the following enzymes to be present: Lactase, maltase, invertase, glycogenase, lipase, trypsin and erepsin. He believed the lactase, maltase, invertase, and renin to be products of bacteria in the intestine of the larva. Brown (1928) believes that most of the enzymes Found in the honeybee are produced by microorganisms. It would seem that in most of the studies on the sacchrolytic enzymes of insects too little attention has been given to the large amounts of these enzymes which bacteria are capable of producing.

Portier (1911) claims that leaf-mining larvae of Nepticula malella and Gracilaria syringella live under sterile conditions and do not harbor any microorganisms in their bodies. On the other hand, the normal leaffeeding larva of the silkworm, Bombyx mori, has its digestive tube populated with bacteria, some of which destroy the wall of the leaf cell, while other bacteria thrive on its contents which is used directly as food. Glaser (1925), however, rearea large numbers of silkworms and rarely found many bacteria in the digestive system of normal worme. Then bacteria became numerically high, the worms ailed and died. Hering (1926) criticizes some of the views of Portier, stating that up to that time no true "symbiont:" were known in leaf-miners. Werner (1926) found the digestive tract of the larva of Potosia cuprea to have a very rich microflora able to cause the fermentation of cellulose. A specific bacterium was isolated 
ind named Bacillus cellulosam fermentans. Schütte (1921) fourd that cellulose is digested by the larva of Hydromyza livens, but apparently without the aid of bacteria.

It should be remembered, when one is considering the role of cellulose-fermenting bacteria in the nutrition of insects, that in most phytophagous insects the food passes through the gut so rapidly that no great amount of fermentation is likely to take place. The breakdown of cellulose by bacteria is usually too slow a process to be initiated and completed in the few hours during which food remains in the gut. On the other hand, cellulose-splitting bacteria are often associated with the food ingested by insects and for this reason cannot be completely ignored. Furthermore, certain insects, such as the Lamellicorn larva, possess "fermentation chambers" which are probably used for such purposes.

In 1919 Roubaud asserted that adult tsetse flies were exclusively hemophagous. The blood ingested by the flies was digested only in the middle section of the intestine where the epithelial cells include symbiotic organisms. According to Roubaud, these organisms play an important part in the digestion of the blood. Wigglesworth (1929) states, however, that there is no evidence that these organisms play any part in the digestion of the blood.

Fermentation chambers. As has already been mentioned, the gut of certain insects, notably Lamellicorn larvae, possess special sacs or chambers containing bacteria which are probably responsible for breaking down the cellulose ingested by the insect. Cuticular areas bearing branched spines occur on the walls of the chamber. The thin cuticle between these areas is pierced by fine canals. It appears that most of the digestion and absorption takes place within this chamber since the tiny particles of cellulose and wood are retained here for long periods of time and are acted upon by the cellulose-fermenting bacteria therein.

According to Werner (1926), larvae of Potosia (Cetonia), which feed on the decaying pine needles found in ant heaps, thrive only at those temperatures optimum for the cellulosefermenting bacteria. Similar fermentation chambers are also possessed by certain Lipulids. Thero are some insects, such as the larvae of Dorcus and Osmoderma, which possess "fermentation chambers" filled with bacteria which apparently do not break down the cellulose they ingest. 
Bacteria as a source of vitamins and growth-accessory substances. Portier (1919) was one of the first to suggest that the source of vitamins for the individual insect is the intracellular organisms it possesses. Wollman (1926) probably overlooked this possibility when he claimed that cockroaches (Blattella germanica) may dispense with vitamins and generalized that perhaps vitamins are not essential to insects. Though others (Frost, Herms, and Hoskins, 1936; Bowers and McCay, 1940) have shown that mosquitoes, cockroaches, and other insects can apparently do without certain vitamins, it has been definitely demonstrated that by and large insects need the essential growth substances as do higher animals. Some writers (Imms, 1937) have speculated that the chief functions of bacteria in insects are to supply growth promoting substances and to liquefy the food.

Hobson (1933) found that the larvae of the blow fly, Lucilia sericata, were unable to develop aseptically on sterile blood owing to the lack of growth factors of the vitamin B type. The presence of bacteria improved growth, and yeast autolysate allowed the larvae to grow at a normal rate. Later (1935), he reported that the natural flora must supply the necessary vitamins and that larvae grow readily on blood inoculated with pure cultures of various bacilli isolated from the intestine and from blown meat. Escherichia coli proved equally effective. in these experiments. Observations of Wigglesworth (1936) on Rhodnius prolixus support the view that symbiotic organisms in exclusively blood-sucking insects provide an endogenous source of vitamins.

At this point we may conclude that insect larvae can be reared on sterile media if they are supplied with all the necessary food factors. As stated by Wigglesworth (1939), "If these are deficient, infection with microorganisms (in the case or Drosophila, particularly the introduction of yeasts) improves the rate of growth. Sterile Lucilia larvae will grow on beef muscle; the fail to grow on guinea pig muscle; but if this is inlected with Bacillus coli or if a yeast extract is added to it, normal growth takes place, ***In these cases there is little doubt that the microorganisms are synthesizing the necessary vitamins of the 'B' group."

In connection with a discussion of growth accessory substances might be mentioned the interesting discovery by Tatum (1939) that certain bacteria synthesize a 
"hormone" which can change the eye color from white to brown in Drosophila flies being reared on tryptophane. Neither the bacteria nor tryptophane separately have any influence on the production of eye pigment. In the presence of both the bacteria and tryptophane, however, eye pigmentation is greatly increased. According to Tatum, this shows that tryptophane is able to modify eye-color only through the intermediation of microorganisms.

Bactericidal principle associated with ticks and insects. Through the work of Hindle and Duncan (1925) and Duncan (1926) it is known that certain arthropods possess a bactericidal principle in their alimentary tracts. These workers found that while Bacillus anthracis, Bacillus subtilis, and streptococcus faecalis were able to survive in the alimentary canal of the fowl tick, Argas persicus, others, such as Staphylococcus aureus died quickly after ingestion by the tick and when tested in vitro the stomach contents were found to be definitely bactericidal to Staphylococcus aureus, Bacillus anthracis, and Bacillus mycoides. The results with Pasteurella pestis and Bacillus subtilis were inconclusive. Eberthella typhosa, Serratia marcescens, Brucella abortus, and Streptococcus faecalis were not affected. The inhibitory principle, the potency of which varied with the individual tick, was not inactivated by exposure to a temperature of $58^{\circ} \mathrm{C}$. for thirty minutes.

Duncan (1926) investigated further the nature of the bactericidal action and its occurrence or non-occurrence in the following arthropods: Stomoxys calcitrans, Musca domestica, Anopheles bifurcatus, Aedes cinereus, Cimex lectularius, Rhodnius prolixus, Argas persicus, and Ornithodoros moubata. He demonstrated a bactericidal principle in the gut contents of all of these, and with the exception of the last two (ticks), in the feces as well. Staphylococci and the spore-forming aerobes were the bacteria most affected by this bactericidal principle. These included Staphylococcus aureus, Staphyloccus albus, Bacillus anthracis, Bacillus subtilis, Bacillus mesentericus, and Bacillus vulgatus. Also inhibited by the gut contents of Argas persicus were Neisseria catarrhalis and Streptococcus hemolyticus. Apparently there is only one active principle in any given species of arthropod but different groups of bacteria possess varying degrees of susceptibility to it. The widest range of action, in Duncan's tests, was exhibited by the gut contents of Argas persicus and Stomoxys calcitrans and the narrowest by those of the bugs. The spore- 
forming bacilli were the most susceptible to the gut contents of $\underline{S}$. calcitrans while the staphylococci were more affected by the material from A. persicus.

As to the properties of the active principle, Duncan states: "***bactericidal action is greater and more rapid a.t $37^{\circ} \mathrm{C}$. than at room temperature. This action is not accompanied by any visible bacteriolysis. The bactericidal principle retains its activity unimpaired for at least six months when kept in the dry state. It is very thernostable, resisting temperatures as high as $120^{\circ} \mathrm{C}$. It is not destroyed by tryptic digestion. It is precipitated from solution with proteins by alcohol or acetone, but is not itself affected by these reagents. It is not soluble in the common fat-solvents, ether, chloroform, alcohol, or acetone. By allowing it to act upon repeated small doses of bacteria, it rapidly becomes exhausted and it can be inactivated, possibly through adsorption, by large doses of killed bacteria; even those species which are not destroyed by it. It may also be adsorbed in small amount by bibulous paper. It exhibits none of the properties of bacteriophage, and it differs from lysozyme.

"Regarding the source of the active principle, there is no doubt that it is formed in the stomach, but whether as a secretion of the gastric cells or as a result of the processes of digestion is not clear. (Nuttall, 1909), showed that the destruction of Spirochaeta duttoni in the gut of the bedbug was definitely related to digestion.)"

Surgical maggots. According to Livingston and Prince (1932), as early as the sixteenth century Paré observed that suppurating wounds in which blow plies had deposited their eggs healed with unusual rapidity. Larrey, the eanous surgeon of Napoleon, observed that during the Syrian campaign the presence of larvae in the soldiers' wounds enhanced the healing processes. Other early ph:sicians noticed the relationship between maggots and the hraling of wounds. The real impetus to the study of this relationship came with the observations of Brer (1929, 1931) who, during the first World War, noticed that men wounded in battle and left unattended on the battlepteld for as long as 7 days before being taken to the dressing stations frequently had their wounds infested with maggots. These men had no fevers and did not develop infections nearly as orten as did those who had received early treatment. He observed that after cleaning their wounds, instead of pus and debris, they were filled with healthy, pinik granulation tissue. Baer concluded: 
"Maggots have been found to be a tremendously useful adjunct to thorough surgical treatment of chronic osteomyelitis. . .

"Maggots, by their digestive action, clear away the minute fragments of bone and tissue sloughs caused by operative trauma in a way not accomplished by any other means. This is a tremendously valuable asset in the healing of a wound.

"Maggots cause wounds to become alkaline and in this way diminish growth of pathogenic bacteria.

"Maggots seem to have other more subtle biochemical effects within the wound itself and perhaps cause also a constitutional reaction inimical to bacterial growth."

Though Baer did not live to fully investigate the "more subtle biochemical effects," subsequent investigation has shed more light on this phenomenon.

The following species of fly larvae were used in the early treatment of osteomyelitis: Lucilia sericata Meig., L. caesar Linn., Phormia regina, and Wohlfahrtia nuba Wièd. Lucilia sericata was used most commonly. After working with this species, Stewart (1934) concluded:

"L. sericata larvae are beneficial in osteomyelitis wounds because they injest, by means of macerating mouth-hooks and excreted tryptase, acid forming and bacterial-growth-supporting necrotic tissue; because, most, if not all, of the bacteria ingested with the necrotic tissue and pus are killed by the acid in the middle portion of the mid-intestine; because they alkalize the wounds by means of excreted ammonia and calcium carbonate, and thereby reduce swelling, consequently increasing drainage and decreasing bone destruction and protect tissue cells from autolysis; because the exuded calcium carbonate stimulates phagocytosis; because the bacterial exotoxin is probably rendered inert by the acid condition of the middle region of the mid-gut; and because they promote the growth of healthy granulation tissue apparently by either raising the $\mathrm{pH}$ of the wound or by the activity of the exuded calcium ions, or both." 
In 1935 Simmons obtained, from the excretions of the maggots, a thermostable bactericidal substance which would kill such bacteria as Staphylococcus aureus, hemolytic streptococci, and Clostridium welchi. In the same year Robinson (1935) isolated allantoin from maggot excretions.

Allantoin occurs naturally in animal and plant tissues as a metabolic product from the break down of cell nuclei. The amount of allantoin in the excretions of maggots is too small and the process of extraction too involved to be practical (Robinson, 1937). Other methods of preparing the chemical were devised and it was soon generally available. Upon hydrolysis, one of the side chains of allantoin is split off and goes to form urea. Though, according to Robinson (1937), it has not been shown that the effect of allantoin is due to this hydrolysis, it was soon found that urea (also present in the excretions of maggots) likewise has definite healing properties. Thus, through the careful observation of maggots in human wounds the healing properties of allantoin and urea were rediscovered. 1

IThe original but forgotten discovery of the healing properties of allantoin was made by Macalister (1912).

\section{$\underline{\text { References }}$}

Allen, T. C. and Riker, A. J. 1932 A rot of apple fruit caused by Phytomonas melophthora, n. sp., following invasion of the apple maggot. Phytopath. 22, 557-571. Atkin, E. E., and Bacot, A. 1917 The relation between the hatching of the eggs and the development of the larvae of Stegomyia fasciata (Aedes calopus), and the presence of bacteria and yeasts. Parasitol., 2, $482-536$. Bacot, A. 1911 On the persistence of bacilli in the gut of an insect during metamorphosis. Trans. Entomol. Soc. London, 497-500.

Bacot, A. 1914 On the survival of bacteria in the alimentary canal of fleas during metamorphosis from larva to adult. J. Hyg. (Plague Supplement III), (Jan. 14) 655-664.

Bacot, A. 1916 Reports on questiors connected with the investigation of nonmalarial fevers in West Africa. Yellow Fever Commission to West Africa. III. 1-19l.

Bacot, A. 1917 The effect of the presence of bacteria or yeasts on the hatching of the eggs of Stegomyia fasciata (the yellow fever mosquito). J. Royal Microscop. Soc., Part I., 173-174. 
Baer, W. S. 1929 The use of a viable antiseptic in the treatment of osteomyelitis. South. Med. J., 르, 582-583. Baer, W. S. 1931 The treatment of chronic osteomyelitis with the maggot (larva of the blow fly). J. Bone \& Joint Surg., 13, 438.

Barber, M. A. 1914 Cockroaches and ants as carriers of the vibrios of Asiatic cholera. Philippine J. Sci., Sec. B. , 2, 1-4.

Barber, M. A. 1927 The food of anopheline larvae. Food organisms in pure culture. U. S. Pub. Health Repts., 42, $1494-1510$.

Barber, M. A. 1928 The food of culicine larvae. Food osganisms in pure culture. U. S. Pub. Health Repts., $43,11-17$.

Baumberger, J. P. 1.919 A nutritional study of insects, with special reference to microorganisms and their substrata. J. Exptl. Zool., 28, 1-81.

Bogdanow, E. A. 1906 Utber das Züchten der Larven der gewohnlichen Fleischfliege (Calliphora vomitoria) in sterlisierten. Nährmitteln. Pflügers Arch. ges. Physiol., 113, 97-105.

Bogdanow, E. A. 1908 thber die Abhangigkeit des Wachstums der Fliegenlarven von Bakterien and Fermenten und Uber Variabilitat und Vererbung bei den Fleischfliegen. Arch. Anat. Physiol. Anat. Abt., 173-200.

Bowers, R. E. and McCay, C. M. 1940 Insect life without vitamin A. Science, 92, 291.

Brown, F. M. 1928 Enzymes and bacteria in the honey-bee. Am. Museum Novitates, No. 304, 5 pp.

Burnside, C. E. 1934 Studies on the bacteria associated with European foulbrood. J. Econ. Entomol., 27, 656-668.

Chapman, R. N. 1924 Nutritional studies on the confused flour beetle, Tribolium confusum Duval. J. Gen. Physiol., $6,565-585$.

Cheshire, F. R. and Cheyne, W. W. 1885 The pathogenic history and the history under cultivation of a new bacillus ( . . alvei), the cause of a disease of the hive bee hitherto known as foul brood. J. Roy. Microscop. Soc., series 2, 5, 581-601.

Cox, G. L., Lewis, F. C., and Glynn, E. E. 1912 The numbers and varieties of bacteria carried by the common house-fly in sanitary and insanitary city areas. J. Hyg., 12, 290-319.

Dean, R. W. 1933 Morphology of the digestive tract of the apple maggot fly, Rhagoletis pomonella Walsh. New York (Geneva) Agri. Exp. Stat. Tech. Bull. 215.

Dean, R. W. 1935 Anatomy and postpupal development of the female reproductive system in the apple maggot fly, Rhagoletis pomonella Walsh. New York (Geneva) Agri. Exp. Stat. Tech. Bull. 229. 
Duncan, J. T. 1926 on a bactericidal principle present in the alimentary canal of insects and Arachnids.

Parasitol. 18, 238.

Dyson, J. E. B. and Lloyd, L. 1933 Remarks on the flies breeding in the bacteria beds at the Knostrop Sewage Works, Leeds. Surveyor, 84, 335-337.

Forbes, S. A. 1892 Bacteria normal to digestive organs of Hemiptera. Bull. Ill. State Lab. Natural Hist, , Art I., V. 4.

Frost, F. M., Herms, W. B., and Hoskins, W. M. 1936 The nutritional requirements of the larva of the mosquito, Theobaldia incidens (Thom.). J. Exp, Zool., 73, $461-479$.

Gjullin, C. M., Yates, W. W., and Stage, H. H. 1939 The effect of certain chemicals on the hatching of mosquito eggs. Science, 89, 539-540,

Glaser, R. W. 1924 The relation of microorganisms to the development and longevity of flies. Am. J. Trop. Med. , 4, 85-107.

Glaser, $\bar{R}$. W. 1925 specificity in bacterial diseases with special reference to silkworms and tent caterpillars, J. Econ. Entomol., 18, 769-771,

Glaser, R. W. 1938 A method for the sterile culture of houseflies. J. Parasitol., 24, 177-179.

Glasgow, H. 1914 The gastric caeca and the caecal bacteria of the Heteroptera. Biol. Bull. Marine Bio. Lab., 26, 101-170.

Graham-Smith, G. S. 1909 Preliminary note on examinations of flies for the presence of colon bacilli.

Gt. Brit. Local Govt. Bd., Rpts. Pub. Health and Med. Subjs. New Series, No. 16, 9-13.

Graham-Smith, G. S. 1913 Flies in relation to disease. Cambridge Univ. Press, London, 292 pp.

Guyénot, E. 1906 Sur le mode de nutrition de quelques larves de mouches. Compt. rend. soc. biol., 61, 634-635. Guyénot, 巴. 1907 L'appareil digestive de quelques larves des mouches. Bull. sci. France Belg., 4l, 353-370. Hering, M. 1926 Die Oekologie der blattminierenden Insektenlarven. Chapt. 10 (pp. 100-144), Berlin. Hertig, M. 1923 The normal and pathological histology of the ventriculus of the honey-bee, with special reference to infection with Nosema apis. J. Parasitul., 9, $109-140$.

Hewitt, C. G. 1914 The house-fly. Cambridge Univ。 Press, London. $382 \mathrm{pp}$.

Hindle, E. and Duncan, J. T. 1925 The viability of bacteria in Argas persicus. Parasitol., 17, $434-446$. 
Hinman, E. H. 1930 A study of the food of mosquito larvae. (Culicidae). Am. J. Hyg., 12, 238-270,

Hinman, E. H. 1932 The presence of bacteria within the eggs of mosquitoes. Science, 76, 106-107.

Hinman, E. H. 1933 The role of bacteria in the nutrition of mosquito larvae. The growth-stimulating factor. Am, J. Hyg., 18, 224-236.

Hobson, R. P. 1933 Growth of blow-fly larvae cn blood serum. I. Response of aseptic larvae to vitamin B. Biochem. J., 27, 1899-1909.

Hobson, R. P. 1935 Growth of blow-fly lervae on blood and serum. II Growth in association with bacteria.

Biochem. J., 29, 1286-1291.

Inms, A. D. 1937 Recent advances in entomology. London, J. \& A. Churchill Ltd. Ind. ed. $431 \mathrm{pp}$.

Jackson, D. D. 1907 Report to committee on poliution of the Merchant's Association of New York, (Cited by Graham-Smith, 1913).

Kuskop, M. 1924 Bakteriensymbiosen bei Wanzen. Arch.

Protistenk., 47, 350-385.

Lal, R. B., Ghosal, S. C., and Mukherji, B. 1939 Investigations on the variation of vibrios in the house fly. Indian J. Med. Res., 26, 597-609.

Leach, J. G. 1931 Further studies on the seed-corn maggot and bacteria with special reference to potato blackleg. Phytopath. 21, 387-406.

Leach, J. G. 1933 Methods of survival of bacteria in puparia of the seed corn maggot (Hylemyia cilicrura Rond.). Z. angew. Entomol., 20, 150-161.

Leydig, F. 1857 Lehrbuch der Histologie des Menschen und der Thiere. Frankfurt a. M., p. 337.

Livington, S. K. and Prince, L. H. 1932 The treatment of chronic osteomyelitis. With special reference to the use of maggot active principle. J. Am. Med. Ass., 98, 1143.

Longfellow, R. C. 1913 The common house roach as a carrier of disease. Am. J. Pub. Health, 3, 58-61,

Maassen, A. 1908 Zur Etiologie der sogenannten Faulbrut der Honiobienen. Arbeiten K. Biol. Anst. Land. $u$. Forstev., 6, 53-70.

Macalister, $\bar{C}$. J. 1912 A new cell proliferant. Its clinical application in the treatment of ulcers. Brit, Med. J., I, 10-12.

Melampy, R. M. and MacLeod, G. F, 1939 Bacteria isolated from the gut of the larval Agriotes mancus (Say). J. Econ. Entomol., 31, 320.

Mitchell, E. 1907 Mosquito life. G. P, Putnam and Sons, New York. $145 \mathrm{pp}$. 
Nicoll, W. 1911 on the varieties of Bacillus coli associated with the house-fly (Musca domestica). J. Hyg., 11, 381-389.

Paillot, A. I933 L'infection chez insectes. Imprimerie de Trevous. $535 \mathrm{pp}$.

Parker, R. R. and Spencer, R. R. 1924 Tularaemia. XI. Tu.Laraemia infection in ticks of the species Dermacentor andersoni Stiles in the Bitterroot Valley, Mont. Pus. Health Rpts., 39, 1057-1073.

Petri, L. 1905 Ulteriori richerche sopra i batteri che si trovano nell' intestino della larva della Mosca olearia. Atti. acad. Lincei, 14, 399-404.

Petri, L. 1909 Ricerche sopra $\bar{i}$ batteri intestinali della Mosca olearia. Memorie R. Staz. Patol. Veg. Roma, 4, 1-130.

Petri, L. 1910 Utersuchungen Uber die Darm-bakterien der Olivenfliege. Zentr. Bakt. Parasitenk., II. Abt., 25, $357-367$.

Portier, P. 1911 Passage de l'asepsie a l'envahissement symbiotique humoral et tissularire par les microorganisms dans la série des larves des insèctes. Compt. rena. soc biol., 70, 914-917.

Portier, P. 1919 Developpement complet des larves de Tenebrio molitor, obtenu au moyen d'une nourriture sterilisée a haute température (1300). Compt. rena. soc. biol., 82, 59-60.

Robinson, W. 1935 Stimulation of healing in norhealing wounds by allantoin occurring in maggot secretions and of wide biological distribution. J. Bone and Joint Surg. , 17, 267-271.

Robinson, $\vec{W} .1937$ The healing properties of allantoin and urea discovered through the use of maggots in human wounds. Smithsonian Rpts., 451-461.

Robinson, W. and Norwood, V. H. 1934 Destruction o? pyogenic bacteria in the alimentary tract of surgical maggots implanted in infected wounds. J. Lab. Clin. Med., 19, 581-586.

Roubaud, E. 1919 Les particularités de la nutrition et la vie symbiotique chez les mouches tsétsés. Ann. inst. Pasteur, 33, 489-536.

Rozeboom, L. E. 1934 The effect of bacteria on the hatching of mosquito eggs. Am. J. Hyg., 20, 496-501. Rozeboom, L. E. 1935 The relation of bacteria and bacterial filtrates to the development of mosquito larvae. Am. J. Hyg., $\frac{21}{4}, 167-179$.

Schütte, L. 1921 Das T⿱艹⿰丿丨nchen der Musciden. Zoo. Anz., 53, 49-51.

simmons, S. W. 1935 A bactericidal principle in excretions of surgical maggots which destroys important etiological agents of pyogenic infections. J. Bact., $30,253-267$. 
Simmons, S. W. 1939 Digestive enzymes of the larva of the cattle grub Hypoderma lineatum (De Villiers). Ann. Entomol. Soc. Am., 32, 621-627.

Stamner, H. J. 1929 Die Bakteriensymbiose der Trypetiden (Diptera). Z., Morphol. Ök̈ol. Tiere (Abt. A. Z. wiss Biol.) 15, 481-523.

Steirhaus, E. A. 1940 The microbiology of insects. Bact. Rev. . 4, 17-57.

Steinhaus, E. A. 1941 A study of the bacteria associated with thirty species of insects. J. Bact., 42, 757-790, Steinhaus, E. A. 1942 The microbial flora of the Rocky Mountain wood tick, Dermacentor andersonl Stiles.

J. Bact., in press.

Steinhaus, E. A. 1942 A bacterium associated with the louse fly, Iipoptena depressa. J. Parasitol., In press. Tatum, E. L. 1939 Development of eye-colors in Drosophila: Bacterial synthesis of $\mathrm{V}^{+}$hormone. Proc. IJatl. Acad. Sci. U. S., 25, 486-490.

Thorpe, W. A. 1930 The biology of the petroleum fly (Psilopa petrolii, Coq.). Trans. Entomol. Soc. London, $78,331-344$.

Torrey, J. C, 1912 Numbers and types of bacteria carried by city flies. J. Infect. Diseases, 10, 166-167.

Trager, W. 1935a The culture of the mosquito larvae

free from living microorganisms. Am. J. Hyg., 22, 18-25. Trager, $W .1935 \mathrm{~b}$ on the nutritional requirements of mosquito larvae (Aedes aegypti). Am. J. Hyg., 2 2?, 475-493.

Trager, W., Miller, D. K., and Rhoads, C. P. 1938 The absence from the urine of pernicious anemia patients of a mosquito growth factor present in normal urine. J. Expt. Med. 67, 469-480.

Weinland, E. 1907 Weitere Beobachtungen an Calliphora. IV. ther chemische Momente bei der Metamorphose (und Entwicklung). Z. Biol., 49, 486-493.

Weinland, E. 1908 Uber die Bildung von Fett aus eiweissartiger Substanz im Brei der Calliphoralarven. Z. Biol., 51, 197-278.

Werner, E. 1926 Die Ernthrung der Larve von Potosia cuprea, Frb. (Cetonia floricola Hbst.) Ein $\overline{\text { Beitrdyg }}$ zum Problem der Celluloseverdaung bei Insectenlarven. Z. Morphol. Okol. Tiere (Abt. A. Z. wiss Biol.) 6 , $150-206$.

White, G. F. 1906 The bacteria of the apiary with special reference to bee diseases. U. S. Dept. Agr., Bur.

Entomol., Tech. Bull., No. 14, 50 pp.

White, G. F. 1912 The cause of European foulbrood. U. S. Dept. Agr. Bur. Ent. Cir. 157, 15 pp. 
White, G. F. 1920a European foulbrood. U. S. Dept. Agr. Bul. 810, $39 \mathrm{pp}$.

White, G. F. 1920b Some observations on European foulbrood. Am. Bee J., 60, 225-227; 266-268.

Wigglesworth, V. B. $1 \overline{929}$ Digestion in the tsetse-fly: a study of structure and function. Parasitol., 2.1 , 288-321.

Wigglesworth, V. B. 1936 Symbiotic bacteria in a bloodsucking insect, Rhodnius prolixus Stal. (Hemiptera, Triatomidae). Parasitol., 28, 284-289.

Wigglesworth, V. B. 1939 The principles of insect physiology. E. P. Dutton and Co., Inc., New York, $434 \mathrm{pp}$.

Wollman, E. 1911 Sur l'élevage des mouches steriles. Contribution a la connaissance du role des microbes dans les voies digestives. Ann. inst. Pasteur, 25, 79-88.

Wollman, E. 1921 La méthode des élevages aseptiques en physiologie. Arch. intern. physiol., 18, 194-199. Wollman, E. 1926 Observations sur une lignée aseptíque de Blattes (Blattella germanica) datant de cinq ans. Compt. rend. soc. biol., 95, 164-165.

Von Wolzogen Kthr, C. A. H. 1931-32 thber eine Garrungsmikrobe in Fllkalien von Mückenlarven. Zentr. Bakt. Parasitenk., II. Abt. 85, 223-250.

Yao, H. Y., Yuan, I. C., and Huie, D. 1929 The relation of flies, beverages and well water to gastro-intestinal diseases in Peiping. Nation. Med. J. China, 15, 410-418. 
The orders, families, tribes, genera, and species of the bacteria here catalogued are listed in alphabetical order as shown by the Table of Contents. More than 300 specific names of the bacteria which have in some way or other been associated with insects or ticks are listed. The system of bacterial classification followed is that used in Bergey's Manual of Determinative Bacteriology (1939, 5th edition).

Under the appropriate order, family, tribe, and genus, the scientific name for each species of bacterium is given as a heading. When known, the specific name is followed by the authority. On the next line, in parenthesis, are given the important synonyms or names of bacteria similar or identical to the species given in the heading. This is followed by the names of the arthropods with which the bacterium in questton is associated. Next is a short abstract or synopsis of the nature of its arthropod relationship. The references cited in the discussion are listed after each cataloguing. Those references which are marked with an asterisk are the references to the papers in which the original description or mention of the bacterium was made. This catalogue should not be considered bibliographic. The references listed are those which will give the reader the most readily available, complete, and pertinent citations on the bacterium in question. The indices should be used to find any particular bacterium or insect. The bacteria are indexed separately from the insects and ticks.

The author has attempted to use the more recent names of the insects and ticks listed, but may not have done so in all cases. For the bacteria we have listed the name of the bacterium as designated in the original reference and its present name, according to Bergey's Manual. Cross references to bacterial synonyms have been kept to a minimum in the text. For the most part these have been shown in the index. 
Class: S C H I Z O M Y C E T E S

Order: ACTINOMYCETALES

Family: ACT INOMYCETACEAE

Genus: Leptotrichia

Leptotrichia buccalis (Robin) Trevisan

(See Leptotrix buccalis)

Family: MYCOBACTER IACEAE

\section{Genus: Corynebacterium}

\section{CORYNEBACTER IUM BLATELLAE Glaser}

Insect concerned: The German roach, Blattella germanica.

In the fat body of the cockroach are found bacteriocytes, the cytoplasms of which are filled with microorganisms. Glaser (1930b) claims to have cultivated these organisms from the German roach on artificial media, and gave the name Corynebacterium blattellae to the diphtheroidal forms he isolated. Earlier (1930a), he reported on a similar organism which he isolated from the American roach, Periplaneta americana (see Corynebacterium periplanetae var. americana). Gier (1936) obtained only negative results in his attempts to cultivate the "bacteroids" from roaches.

For a brief description of this organism see Bergey's Manual (5th ed., page 798).

Gier, H. T. 1936 The morphology and behavior of the intracellular bacteroids of roaches. Biol. Bull., Il, 433-452.

Glaser, R. W. 1930 a on the isolation, cultivation and classification of the so-called intracellular "symbiont" or "rickettsia" of Periplaneta americana. J. Expti. Med., 51, 59-82.

* Glaser, $\bar{R}$. W. $1930 \mathrm{~b}$ Cultivation and classification of "bacteroids," "symbionts," or "rickettsiae" of Blattella germanica. J. Exptl. Med., 51, 903-907.

CORYNEBACTERIUM DIPHTHERIAE (Flügge) Lehman and Neumann

Insects concerned: The bee moth, Galleria mellonella; the house fly, Musca domestica; the roach, Periplaneta orientalis. 
Metalnikov (1920) carried out a number of experiments to determine the susceptibility of the larvae of the bee moth to infection with Corynebacterium diphtheriae, and found them to be completely immune. However, according to Huff (1940), Chorine made a series of experiments and found aiphtheria toxin to be toxic for the caterpillars of Galleria mellonella. He also was able to produce an immunity in the larvae by use of an "anatoxin."

The house fly has been suggested as a possible vector of diphtheria bacilli. Graham-Smith (1910) made a series of experiments which seemed to indicate that Corynebacterium diphtheriae does not remain alive for more than a few hours on the legs and wings of house flies, but may live for 24 hours or longer in the intestinal tract. He states (1913), "There is no evidence that under natural conditions flies are concerned in the spread of this disease. . but, under suitable conditions, it is possible that the disease may be occasionally conveyed by them."

Longfellow (1913) cultivated the Westbrook type of diphtheria bacillus from the feces of roaches.

Graham-Smith, G. S. 1910 Observations on the ways in which artificially infected flies (Musca domestica and Calliphora erythrocephala) carry and distribute pathogenic and other bacteria. Reports to the Local Gov. Bd. Public Health and Medical Subjects, No. 53, 3-148. Graham-Smith, G. W. 1913 Flies in relation to disease. $292 \mathrm{pp}$. University press, Cambridge. (See p. 186.) Huff, Clay G. 1940 Immunity in invertebrates. Physiol. Reviews, 20, 68-88.

Longfellow, $\bar{R}$. C. 1913 The common house roach as a carrier of disease. Am. J. Pub. Health, 3, 58-61. Metalnikov, S. 1920 Immunité de la chenille contre divers microbes. Compt. rend. soc. biol., 83, 119-121.

\section{CORYNEBACTERIUM PAUROMETABOLUM Steinhaus}

Insect concerned: The bedbug, Cimex lectularius.

While attempting to cultivate an intracellular "symbiote" from the ovaries and mycetome of the bedbug, Steinhaus (1941) isolated a diphtheroid which he named Corynebacterium paurometabolum. The cultivated organism appeared very similar to the slender rod-shaped bacterium observed in the tissues of the ingect. At first, efforts to cultivate the organism from the tissue were unsuccessful when routine bacteriologic media were used though it 
did grow in a special semi-solid medium. In subsequent attempts, however, the same organism was isolated directly on glucose agar. Corynebacterium paurometabolum appeared to be constantly associated with the bedbug.

During the same investigation an unidentified diphtheroid was isolated from the alimentary tract of the larvae of the bagworm, Thyridopteryx ephemeraeformis. The two diphtheroids were similar in many respects, differing in a few minor characteristics.

* Steinhaus, E. A. 1941 A study of the bacteria associated with thirty species of insects. J. Bact., 42, 757-790.

CORYNEBACTERIUM PERIPLANETA VAR. AMERICANA GLaser

Insect concerned: The American roach, Periplaneta americana.

From the fat body of the American roach, Periplaneta americana, Glaser (1930a) isolated and cultivated a diphtheroid bacterium which he named Corynebacterium periplanetae var. americana. Soon after this he (1930b) cultivated a similar bacterium, Corynebacterium blattelae, from the German roach Blattella germanica. Gier (1936) has reported negative results in his attempts to cultivate the microorganisms found in the bacteriocytes of the roach fat tissue. Glaser explains the failure of other workers to duplicate his results as probably due to faulty technique (see Steinhaus, 1940, p. 40).

For a brief description of this organism see Bergey's Manual, 5th edition, p. 798.

Gier, H. T. 1936 The morphology and behavior of the intracellular bacteroids of roaches. Biol. Bull., 7l, 433-452.

*Glaser, R. W. 1930a On the isolation, cultivation and classification of the so-called intracellular "symbiont" or "rickettsia" of Periplaneta americana. J. Exptl. Med., 51, 59-82.

Glaser, R. W. $1930 \mathrm{~b}$ Cultivation and classification of "bacteroids," "symbionts," or "rickettsiae" of Blattella germanica. J. Exptl. Med., 51, 903-907.

Steinhaus, E. A. 1940 The microbiology of insects with special reference to the biologic relationships between bacteria and insects. Bact. Revs., 4, 17-57. 
MYCOBACTERIUM LEPRAE (G. A. Hansen) Lehman and Neumann

Insects concerned: Chlorops (Musca) leprae; Chlorops vomitoria; the house fly, Musca domestica; Sarcoptes scabei; Sarcophaga pallinervis, Sarcophaga barbata; Volucella obesa; Lucilia sp.; Stomoxys calcitrans; the mosquito, $\overline{\text { Aedes }}$ aegypti; and probably the bedbug, Cimex lectularius; the mite, Demodex; and the cockroach, Periplaneta americana.

Mycobacterium leprae is the causative organism of leprosy. As early as 1872, Hansen observed small rodshaped bacilli lying within the "lepra cells." The leprosy bacillus has never with certainty been cultivated on artificial media. Furthermore, very little is known concerning the method of its transmission. It is conceivable, however, that in some instances the bacilli may be transferred from one person to another by insects.

Rosenau (1927) writes concerning the role of insects in the transmission of leprosy:

"The evidence is reviewed by Nuttall, who says:

'It appears that Linnaeus and Rolander considered that Chlorops (Musca) leprae was able to cause leprosy by its bite.' Blanchard and Corrodor tell of flles in connection with leprosy. Flies frequently gather in great numbers on the leprous ulcers and then visit and bite other persons. An observation by Boek of the presence of Sarcoptes scabei in a case of cutaneous leprosy led Joly to conclude that these parasites might at times serve as carriers of the infection . . Carrasquillo of Bogota found the bacillus of Hansen in the intestinal contents of flies. The British Leprosy Commission investigated the possible role played by insects with entirely negative results. Wherry - . found that the fly Chlorops vomitoria took up enormous numbers of lepra bacilli from the carcass of a leper rat and deposited them with their feces, but the bacilli apparently do not multiply in flies, as the latter are clear of bacilli in less than 48 hours. Larvae of Chlorops vomitoria hatched out in the carcass of a leper rat become heavily infested with lepra bacilli. If such larvae are removed and fed on uninfected meat they soon rid themselves of most of the lepra bacilli. A fly, Musca domestica, caught on 
the face of a human leper was found to be infected with lepra-like bacilli. . Lepra-like bacilli have been found in bedbugs and these insects have long been associated with the spread of the disease."

Currie (1910), in experiments with mosquitoes, found little reason to believe that they were transmitters of the infection. However, Vedder (Riley and Johannsen, 1938) found acid-fast bacilli in 41 per cent of the mosquitoes (Aedes aegypti) which he fed on lesions of leprosy. Currie also found that Musca domestica, Sarcophaga pallinervis, Sarcophaga barbata, Volencella obesa, and Lucilia sp., may contain leprosy bacilli in the ir intastinal tracts and feces for several days after feeding on leprous fluids. The leprosy bacillus was found by St. John, Simmons, and Rejnolds, (1930) to survive in the gut of Aedes aegypti for at least 24 hours but they could not be demonstrated after an interval of seven or more days. Honeij and Parker (1914) concluded from their experiments that Stomoxy3 calcitrans potentially plays an important role as a carrier of the acid-fast bacilli of leprosy. They also found acid-fast bacilli in Musca domestica.

Macfie (Riley and Johannsen, 1932) found that M. Ieprae passed through the cockroach intestine unharmed.

Many other insects than those discussed above have been thought to be associated with Mycobacterium leprae, but most of the evidence is unconvincing.

For a description of Mycobacterium leprae, see Bergey's Manual (5th ed., page 816).

Currie, D. G. 1910 Mosquitoes in relation to the transmission of leprosy. Flies in relation to the transmission of leprosy. U. S. Pub. Health Rept. Bull. 39, $42 \mathrm{pp}$.

Hansen, G. A. 1872 Norsk. Mag. f. Laegevidensk., 2, I. Honeij. J. A., and Parker, R. R. 1914 Leprosy: Plies in relation to the transmission of the disease. J. Med. Research, 30, 127-130.

Rosenau, M. J. 1927 Preventive medicine and hygiene. 5 th ed., $1458 \mathrm{pp}$. D. Appleton and Company, New York.

(See page 420.)

Riley, W. A. and Johannsen, O. A. 1932 Medical Entomology. lst ed., $476 \mathrm{pp}$. McGraw-Hill Book Co., New York. (See p. 121.)

Riley, W. A., and Johannsen, O. A. 1938 Medical entomology. Ina. ed., 483 pp. McGraw-Hill Book Co., New York.

(See page 260.) 
St. John, J. H., Simmons, J. S., Reynolds, F. H. K. 1930 The survival of various microorganisms within the gastrointestinal tract of Aedes aegypti. Amer. J. Trop. Meā., 10, $237-241$.

MYCOBACTERIUM TUBERCULOSIS Lehmann and Neumann

Insects concerned: The bee moth, Galleria mellonella; the house fly, Musca domestica; Achraca grissella; and the cockroach, Periplaneta americana.

Metalnikov (1914) found that the larvae of Achraca grissella, when kept at room temperature, were susceptible to infection with piscine strains of Mycobacterium tuberculosis. In 1920 he showed also that the larvae of the bee moth were susceptible.

Spielman and Hausha.lter (1887) appear to have been the first to express belief that house flies that have fed on tubercular sputum may serve as carriers. They found Mycobacterium tuberculosis in the intestinal contents and feces of flies fed on tubercular sputum. Others (Hofmann, 1885; Celli, 1888; André, 1908; Graham-Smith, 1913) have made similar observations. Riley and Johannsen (1938) express the opinion that laboratory and epidemiological evidence indicates that house flies play a role in the dissemination of tuberculosis.

Macfie (Riley and Johannsen, 1932) fed cockroaches on tubercular sputum and normal tubercle bacilli were isolated from the feces on the second to fifth day. To prove their virulence, guinea pigs were injected, which subsequently became infected. Tejera (1926) also reported that the tubercle bacillus passes through the cockroach intestine unharmed.

Cellí, A. 1888 Trasmissibilita dei germi patogeni mediante le dejectione delle mosche. Bull. d. Soc. Lancisiana d. ospedali di Roma, 1.1. (Quoted by Nuttall and Jepson, 1909, 27). Graham-Smith, G. S. 1913 Flies in relation to disease, $292 \mathrm{pp}$. University Press, Cambridge. (See pp. 175-179.) Hofmann, E. 1888 Ueber die Verbreitung der Tuberculose durch stubenfliegen. Correspondenzbl. d. arztl. Kreis-u. Bezirksvereine im Konigr. Sachsen, 44, 130-133. Metalnikov, S. 1914 De la tuberculose chez les insectes. Compt. rend. soc. biol., 76, 95-96.

Metalnikov, S. 1920 Sur la digestion des bacilles tuberculeux dans le corps des chenilles des mites des abeilles (Galleria mellonella). Compt. rend. soc. biol., 83, 214-215. 
Riley, W. A. and Johannsen, O. A. 1932 Medical Entomology. lst ed., $476 \mathrm{pp}$. McGraw-Hill Book Co., New York. (See p. 121.)

Riley, W. A. and Johannsen, O. A. 1938 Medical Entomology, 483 pp., McGraw-Hill Book Co., Inc., New York and London. (See p. 336.)

Spielman and Haushalter 1887 Dissémination du bacilli de la tuberculose par la mouche. compt. rend. acaả. sci., $\underline{105}, 352-353$.

Tejera, $\mathrm{E} .1926$ Les blattes envisagées comme agentes de dissemination des germes pathogénes. Compt. rend. soc. biol., 25, 1382-1384.

\section{Order: EUBACTERIALES \\ Family: BACILLACEAE \\ Genus: Bacillus}

BACILLUS A Ledingham

Insect concerned: The house fly, Musca domestica.

A non-lactose fermenting bacillus isolated from the feces of children has been found by Tebbutt (1913) to be normal to the house Ply (Musca domestica). It was present on the ova and in the larvae and adults. When the bacillus was fed to the larvae, it survived through the metamorphosis to the adult fly.

Tebbutt, H. 1913 Jour. Hyg. 12, 516-526. Pierce, W. D. 1921 Sanitary entcmology, 518 pp. Gorham Press, Boston. (See p. 109.)

\section{BACILLUS A White}

Insect concerned: The adult honey bee, Aphis mellifera.

White (1906) isolated Bacillus A from the body of a healthy bee and from the combs. Hé indicates that the organism may be the same as $\underline{B}$. mesentericus, and gives a complete description of the organism.

*White, G. F. 1906 The bacteria of the apiary with special reference to bee diseases. U. S. Dept. Agr., Bur. Entomol., Tech. Bull. No. 14, $50 \mathrm{pp}$. 
BACILLUS AEGYPTIUS Trevisan

(See Bacterium conjunctivitides)

\section{BACILLUS AERIFACIENS Steinhaus}

Insect concerned: The cabbage butterfly, Pieris rapae.

Steinhaus (1941) isolated this bacillus from triturated specimens of the white cabbage butterfly. It probably belongs to the aerobacillus group of the genus Bacillus since the original cultures produced large amounts of gas in glucose, sucrose, and maltose.

* Steinhaus, E. A. 1941 A study of the bacteria associated with thirty species of insects. J. Bact., 42, 757-790.

\section{BACILLUS AGILIS}

Insect concerned: Ephestia kihnielia.

Mattes (1927) described Bacillus agilis as a very motile, short bacillus with pointed ends, resembling Bacillus lanceolatus and causing a mila form of foulbrood in bees. He found it to be pathogenic for Ephestia klthniella under certain conditions. This is probably the same bacillus as Bacillus agilis Hauduroy (see Bergey's Manual, 5 th edition, p. 740 ) since both are found in foulbrood of bees.

Mattes, 0. 1927 Parasitäre Krankheiten der Mehlmottenlarven und Versuche Uber ihre Verwendbarkeit als

biologisches Bekämpfungsmittel. Sitzungsberichte der Gesellschaft zur Bedforderung der gesamten Naturwissenschaften zu Marburg, 62, 381-417.

\section{BACILLUS AGROTIDIS TYPHOIDES POSpEIOV}

\section{Insect concerned: Euxoa (Agrotis) segetum.}

In Russia the larvae of Euxoa segetum were found to be killed by a bacterial disease due to a mixed flora which included this bacillus.

* Pospelor, V. P. 1927 Flacherie (septicaemia) of the larvae of Agrotis segetum, Schiff. [In Russian] Rept. Bur. Appl. Ent., 3, 1-23. (English summary.) 


\section{BACILLUS ALACER}

Insect concerned: The nun moth, Lymantria monacha.

Eckstein (1894) found this organism associated with the eggs of the nun moth.

*Eckstein, K. 1894 Untersuchungen Hber die in Raupen vorkommenden Bakterien. Z. f. Forst-und Jagdwesen, 26, $3-20,228-241,285-298,413-424$.

\section{BACILLUS ALBOLACTIS Migula}

Insect concerned: The American roach, Periplaneta americana.

This organism was first isolated from boiled milk. Hatcher (1939) isolated it from the feces of the American cockroach, Periplaneta americana.

According to Bergey's Manual (5th ed., p. 667) this organism agrees in its morphologic and cultural characteristics with Bacillus cereus and is considered to be a variety of the latter. It differs from Bacillus cereus by the acid fermentation of milk.

Hatcher, E. 1939 The consortes of certain North Carolina blattids. J. Elisha Mitchell Sc. Soc., 55, 329-334.

\section{BACILLUS ALVEI Cheshire and Cheyne}

(See $\frac{\text { Bacillus }}{\text { and } \frac{\text { pluton, }}{\text { Streptococcus apis.) }} \text { Achromobacter eurydice, }}$

Insects concerned: The honey bee, Apis mellifera, and Polia oleracea.

Cheshire and Cheyne (1885) first described Bacillus alvei as the cause of the brood disease now known as European foulbrood. The etiology of this disease, which is of great economic importance, has been the subject of considerable controversy. Maassen (1907) believed that it is caused by either Streptococcus apis or Bacillus alvei. White (1912, 1920a, 1920b) was unable to produce typical European foulbrood with Bacillus alvei, Streptococcus apis or Bacterium (now Achromobacter) eurydice and concluded that a new species, Bacillus pluton, was the real cause. Burnside (1924) attempted to bring some order out of the confusion. He found that "Bacillus alvei is 
capable of morphological, cultural, and biological transformation and is also capable of stabilization, at least temporarily, as a sporogenic rod, an asporogenic rod resembling Bacterium [Achromobacter] eurydice, or as a coccoid form resembling Bacillus pluton." Burnside suggests that Bacillus pluton, Streptococcus apis, and Achromobacter (Bacterium) eurydice are variants, or stages in the life history, of Bacillus alvei. (See also Tarr, 1935; and Clark, 1939).

Serbinow (1912) described a disease somewhat unlike foulbrood which he called "blackbrood in bees." Apparently, however, both diseases are caused by Bacillus alvei. Besides bees, other insects, of which Polia $\overline{\text { oleracea }} \overline{\text { is an }}$ example, have been found susceptible to Bacillus alvei. The pupae of Polia oleracea were found by Zorin and Zorina (1928) to be killed by this bacillus.

A complete description of Bacillus alvei may be found in the 5th edition of Bergey's Manual, pages 661-662.

Burnside, C. E. 1934 Studies on the bacteria associated with European foulbrood. J. Econ. Entomol., 27, 656-668. *Cheshire, F. R. and Cheyne, W. W. 1885 The pathogenic history and history under cultivation of a new bacillus (B. alvei), the cause of a disease of the hive bee hitherto known as foul brood. J. Roy. Microscop. Soc., series 2, 5, 581-601.

Clark, F. E. 1939 Nonmotile variants of Bacillus alvei. J. Bact., 38, $491-497$.

Maassen, A. 1907 Zur atiologie der sogenannten Faurbrut der Honigbienen. Arbeiten K. Biol. Anst. Land u. Forstw. , 6, 53-70.

Serbinow, I. L. 1912 Chernaia cherva. Blackbrood in bees. Vestnik Russkava obstschestva pehelovodstra, No. 11, 426-429.

Tarr, H. L. A. 1935 Studies on European foul brood of bees. I. A. description of strains of Bacillus alvei obtained from different sources, and of $\overline{\text { another species }}$ occurring in larvae affected with this disease. Ann. Applied Biol., 22, 709-718.

White, G. F. 1912 The cause of European foulbrood.

U. S. Dept. Agr. Bur. Ent. Cir. 157, 15 pp. White, G. F. 1920a European foulbrood. U. S. Dept. Agr. Bul. 810, $39 \mathrm{pp}$.

White, G. F. I920b Some observations on European foulbrood. Amer. Bee J., 60, 225-227; 266-268. Zorin, P. V., and Zorina, L. M. 1928 Contributions a la biologie de la Polia oleracea. Defense des Plantes, No. 5-6, 5, $475-486$. 


\section{BACILLUS ALVEOLARIS}

Insect concerned: The honey bee, Apis mellifera.

Ksenjoposky, (1916) states that bees suffer from a disease caused by Bacillus alveolaris.

Ksenjoposky, A. V. 1916 Review of the pests of Volhynia and report of the work of Volhynia Entomological Bureau for 1915 (Translation.) Published by the Zemstvo of Volhynia, Jitomir, 1916, 24 pp.

\section{BACILLUS ANTHRACIS Cohn emend. Koch}

Insects and ticks concerned: The biting stable fly, Stomoxys calcitrans; the horsefly, Tabanus striatus; Tabanus rubidus; the horn fly, Haematobia irritans; Tabanus sp., near nigrovittatus; the mosquitoes, Psorophora (Janthinosoma) sayi and Aedes sylvestris; the bedbug, Cimex lectularius; the blow-fly, Calliphora erythrocephala; the ticks, Argas persicus and Boophilus decoloratus; the hide beetle, Dermestes vulpinus; Attagenus pellio; Anthrenus museorum; and Ptinus sp.

The beginning of modern bacteriology was marked by Robert Koch's demonstration, in 1876, of the causal relationship of Bacillus anthracis to anthrax. Earlier, in 1869, Raimbert had shown experimentally that anthrax could be disseminated by flies. According to Herms (1939), Bollinger (1874) is cited by Nuttall as having captured horseflies on a cow dead from anthrax and as having seen the bacilli in preparations made from the stomachs and intestines of the insects. Two rabbits inoculated with this material died of anthrax.

In 1912 Schuberg and Kuhn found that Stomoxys calcitrans fed on the cadaver of an animal dead from anthrax would transmit the infection. They also found viable anthrax bacilli in the guts and feces of the flies for considerable periods after an infective feeding. Mitzmain (1914), working with Tabanus striatus and Stomoxys calcitrans, showed that anthrax could be mechanically transmitted to guinea pigs by the bites of both species. In 1918, Morris found that the horm fly, Haematobia irritans, the horsefly, Tabanus sp., and the mosquitoes, Peorophora (Janthinosoma) sayi and Aedes sylvestris are capable of transmitting anthrax after biting an infected animal. Nieschulz (1935) has reported experimental transmission of anthrax by the bedbug, Cimex lectularius. Duncan (1926) says the anthrax 
bacillus to be very susceptible to a bactericidal principle in the gut-contents of stomoxys calcitrans.

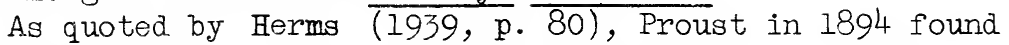
virulent anthrax bacilli in the excrements of the hide beetle, Dermestes vulpinus, taken from goatskins, as well as in the eggs and larvae. Similarly, in 1894, Heim found larvae of Attagenus pellio, Anthrenus museorum, and Ptinus to harbor virulent anthrax spores on their surfaces and in their excreta.

In the case of ticks, Martinaglia (1932) found anthrax bacilli to be still viable 24 hours after ingestion by the blue tick, Boophilus decoloratus, but the bacilli eventually disappeared. Hind and Duncan (1925) found that Bacillus anthracis not only persists in Argas persicus indefinitely but is also passed in the feces at least up to the hundredth day after an infective feeding. An instance of the actual transmission of anthrax to man through the bite of Argas persicus has been recorded (Delpy and Kaweh, 1937).

For descriptions of other experiments on the role of insects in the transmission of anthrax see Graham-Smith (1913) and Nieschulz (1929).

A complete description of Bacillus anthracis may be found in Bergey's Manual (5th ed., page 697).

Delpy, L., and Kaweh, M. 1937 Transmission de Bacillus anthracis a I'home par Argus persicus Oken 1818. Rev. de path. comparée, 37, 1229-1234.

Duncan, J. T. 1926 On a bactericidal principle present in the alimentary canal of insects and arachnids. Parasitol., 18, 238-252.

Graham-Smith, G. S. 1913 Flies in relation to disease. 292 pp. Cambridge University Press, Cambridge.

Herms, W. B. 1939 Medical entomology. 3rd ed., 582 pp. The MacMillan Co., New York.

Hindle, E., and Duncan, J. T. 1925 The viability of bacteria in Argas persicus. Parasitol., 17, $434-446$. Martinaglia, G. 1932 The fate of anthrax bacilli in ticks from an anthrax carcass. J. Amer. Vet. Med. Assoc. , 80, 805-806.

Mitzmain, M. B. 1914 Summary of experiments in the transmission of anthrax by biting flies. Hyg. Lab. Bull. No. 94 , pp. $41-48$.

Morris, H. 1918 Blood-sucking insects as transmitters of anthrax or charbon. Louisiana Agric. Expt. Sta. Bull. No. $163,15 \mathrm{pp}$.

Nieschulz, 0. 1929 Ubber die mechanische thertragung von einigen Bakterienkrankheiten durch blutsaugende Insekten. Arch. Schiffs- u. Tropen- Hyg., 33, 282-287. 
Wieschulz, 0. 1935 Vebertragungsversuche mit Milzbrand und Bettwanzen (Cimex lectularius). Zent. f. Bakt. (Abt. 1.), 135, $228-229$.

Schuberg, A., and Kuhn, P. 1912 Veber die Vebertragung von Krankheiten durch einheimische stechende Insekten. Arb. a. kais. Gesundheitsamte, 40, 209-234.

\section{BACILLUS APISEPTICUS}

Insect concerned: The honey bee, Apis mellifera.

Sweetmar (1936) incluaes Bacillus apisepticus in a partial. list of bacteria known to cause bacterial diseases of insects ari indicates that it is pathogenic to the honey bee.

Sweetman, H. L. 1936 The biological control of insects. $461 \mathrm{pp}$. Comstock Publishing Co., Ithaca, N. Y. (See p. 56.)

\section{BAC LLLUS AUREUS}

Insect concerned: Vanessa polychlorus; Vanessa urticae; Liparis salicis; and Liparis aurifiua.

While studying the infectivity of certain bacteria for various larvae, Eckstein (1894) found that he was able to infect Vanessa polychiorus with Bacillus aureus and that he was mable to infect Vanessa urticae, Liparis salicis, and uparie auriflua.

Two organisms are mentioned by the name Bacillus aureus in Bergey's Manual (5th ed., pp. 629 and 661). Both were described before 1894 so it is difficult to know with which of these, if either, Eckstein worked.

Eckstein, K. 1894 Untersuchungen ther die in Raupen vorkommenden Bakterien. Z. F. forst- und Jagdwesen, 26, $3-20,228-241,285-298,413-424$.

\section{BACILLUS B Hofmann}

(See Bacterium monachae)

Irsect concerned: The nun moth, Lymantria monacha.

This bacillus was isola,ted in 1891 by Hofmann and thought to be the cause of a polyhedral "wilt" disease 
(Wipfelkrankheir) of the nun moth. 'Later experiments have proven the disease is due to a virus. Eckstein ( 1894 ) considered Bacillus $B$ and Bacterium monachae of von Tubeuf (1892a \& b) to be the same.

Eckstein, K. 1894 Untersuchungen ther die in Raupen vorkommenden Bakterien. Z. Forst- u. Jagdwesen, 26, 3-20, 228-241, 285-298, 413-424.

*Hofmann, 0. 1891 Die Schlaffsucht (Flacherie) der Nonne

(Liparis monacha) Nebst einem Anhang. Insektent8tende Pilze mit besonderlr Berucksichtigung der Nonne, 31 pp.

P. Weher, Frankfurt a. M.

v. Tubeuf, C. 1892a. Die Krankheiten der Nonne (Liparis monacha). Forstl. Naturwissensch. Z., I, 34-47, and 62-79.

v. Tubeuf, C. $1892 \mathrm{~b}$ Weitere Beobachtungen thber die Krankheiten der Nonne. Forstl. Naturwissensch. Z., l, 277-279.

\section{BAC ILLUS B White}

Insect concerned: The honey bee, Apis mellifera.

White (1906) found that there occurred very constantly in the pollen and intestines of adult honey bees a species of bacteria he referred to as "Bacillus $\underline{B}$." He gives a full description of the organism.

*White, G. F. 1906 The bacteria of the apiary with special reference to bee diseases. U. S. Dept. Agr., Bur. Entomol., Tech. Bull. No. 14, 50 pp.

\section{BACILLUS BARBITISTES StateloV}

Insect concerned: Isophya (Barbitistes) amplipennis.

This bacillus was isolated from the above tettigonid. An outbreak of an infectious disease due to this organism occurred for the first time in Bulgaria in the spring of 1930. Statelov (1932) has described its cultural characteristics.

* Statelov, N. 1932 Ein pathogenischer Bazillus auf den Larven der Barbitistes amplipennis. Mitt. bulg. ent. Ges., 1, 56-61. 


\section{BACILLUS BOMBYCIS Chatton}

Insects concerned: The silkworm, Bombyx mori; Bothynoderes punctiventris.

Chatton (1913) originally isolated this bacillus from diseased silkworms. It produced a daily mortality of from 5 to 10 in a generation of 2000 silkworms from septicaemia. Paillot (1933) warns that this organism should not be confused with a spore-forming bacillus of the same name isolated by Pasteur. He believes that the "coccobacillus" isoiated from the silkworm by Chatton should be given the name Bacterium bombycis and that the name Bacillus bombycis should be reserved for the spore-forming bacillus studied by Pasteur. Paillot (1928) also refers to a Bacillus bombycis of Macchiate as the cause of dysenteriae of silkworms.

Pospelov (1913) isolated Bacillus bombycis from the larvae of Bothynoderes punctiventris, a pest of sugar beets. The number of larvae suffering from this disease was considerable in the wet summer of 1903 (in Russia).

*Chatton, E. 1913 Septicémies spontanées à coccobacilles chez le Hanneton et le Ver-à-soie. C. R. Acad. Sci., $156,1707-1709$.

Paillot, A. 1928 Les maladies du ver a soie Grasserie et dipenteries, $328 \mathrm{pp}$. Editions du Service Photographique, De I'Université., Lyon. (See p. 215). Paillot, A. 1933 L'infections chez les insectes, 535 p. Imprimerie de Trevoux, Paris. (See p. 125.)

Pospelov, V. P. 1913 Bothynoderes punctiventris, Germ. and methods of fighting it. An Agr. monograph published by Central Board of Land Administration and Agriculture, Dept. of Agr., St. Petersburg. 2nd ed., 116 pp.

\section{BAC ILLUS BOMBYC|S.NON-LIQUEFACIENS Paillot:}

Insect concerned: The gypsy moth, Lymantria dispar.

Paillot (1933) mentions Bacillus bombycis nonliquefaciens and the immunity of the larva of Lymantria dispar to this organism.

Paillot, A. 1933 L'infection chez les insectes, 535 pp. Imprimerie de Trevoux, Paris. (See pp. 288-289.) 
Insect concerned: The silkworm, Bombyx nori.

Sweetman (1936) lists this bacillus as causing a bacterial disease of the silkworm.

Sweetman, H. I. 1936 The biological control of insects. 461 pp. Comstock Publishing Co., Ithaca, N. Y. (See p. 57.)

\section{BPCILLUS BRANDENBURGIENSIS \\ (Bacillus burci and Bacillus larvae)}

Insect concerned: The honey bee, Apis mellifera.

Serbinow (1913) referred to Bacillus brandenburgiensis as the cause of European foulbrood and stated that a large number of experiments proved that it produced the typical form of foulbrood on sealed as well as unsealed brood.

Engelhardt (1914) states that Bacillus brandenburgiensis, when the cause of foulbrood, attacks only the fatty tissues,

White (1920) states that Bacillus larvae, the cause of American foulbrood among bees, has been referred to by Maasen as Bacillus brandenburgiensis and by Cowen as Bacillus burri.

Engelhardt, V. M. 1914 New work on foulbrood. Russian Beekeeping Gazette, Nos. 1-6, Jan.-June, 1914, pp. $12-16,46-49,84-86,126-130,162-165$, and 195-200. Serbinow, I. L. 1913 on the etiology of foulbrood in bees [Economie rurale et forestiere]. Selisk. choz. i. lésovodstvo, 242, 367-382. White, G. F. 1920 American Foulbrood. U. S. Dept. Agri. Bull. 809. Bureau of Entomol., 46 pp.

\section{BACILLUS BURRI}

Insect concerned: The honey bee, Apis mellifera.

White (1920) makes the following statement: "Burri in Switzerland, working on the disease American foulbrood. entirely independently, also recognized the fact that the spores present in such large numbers in the scales represented a new species that was difficult of cultivation. Maasen has referred to the species as Bacillus brandenburgiensis, and Cowan has referred to is as Bacillus 
Burri, R. 1904 Bacteriologische Forschungen ther die Faulbrut. Schweizerische. Bienenzeitung, No. 10, pp. 335-342, Oct., and No. 11, pp. 360-365, Nov. Cowan, T. W. 1911 British bee-keeper's guide book.

20 ed., 8 , $226 \mathrm{pp}$. London.

White, G. $\bar{F} .1920$ American foulbrood. U. S. Dept. Agric., Bur. Entomol. Bull. No. 809, 46 pp.

\section{BAC ILLUS BUTLEROVII SerbinOW}

Insect concerned: The honey bee, Apis mellifera.

Serbinow (1912) was not content to think that the only cause of foulbrood was Bacillus alvei, and in 1911 he isolated Bacillus butlerovii, not only from the diseased brood but also from "contaminated water."

A year later, Serbinow (1913) isolated both B. alvei and $B$ : butlerovii from the digestive tract of the queens of diseased hives, and also from their ovaries and eggs.

* Serbinow, I. I. 1912 A new epizootic of bees in North

European Russia. Věst. Obšč. pčeloved. [Messager de

la Société russe d'apiculture], No. 3, 1912.

Serbinow, I. I. 1913 On the etiology of foulbrood in

bees. Selisk. choz. i. lěsovodstvo, [Economie rurale et forestiere]. 242, 367-382.

\section{BACILLUS BUTSCHLI| Schaudinn}

Insect concerned: The Oriental cockroach, Blatta (Periplaneta) orientalis.

Schaudinn (1902) used this giant bacillus, isolated from the Oriental roach, in making extensive cytologic studies of bacteria.

* Schaudinn, F. 1902 Beitrdge zur Kenntnis der Bakterien und verwandter Organismen. I. Bacillus butschlii n. sp. Arch. Protistenk., I., 306-343.

BACILLUS CACTICIDUS

(See Erwinia cacticida) 
BAC ILLUS CAMPESTRIS Pammel

(See Phytomonas campestris)

\section{BACILLUS CANADENS IS \\ (See Bacterium canadensis)}

Insect concerned: The corn borer, Pyrausta nubilalis.

Paillot (1933) refers to this organism as being a pathogenic spore-former isolated by Chorine from the corn borer, Pyrausta nubilalis. Chorine (1929a, b) and other workers, however, refer to it as "Bacterium canadensis." Paillot gives the size of the spores so it would appear that the generic name Bacillus is preferable.

*Chorine, $V$. 1929a New bacteria pathogenic to the larvae of Pyrausta nubilalis Hb. Internat. Corn Borer Invest.,

Sci. Repts., 2, 39-53.

* Chorine, V. $1 \overline{9} 29 \mathrm{~b}$ Nouveaux microbes pathogenes pour

les chenilles de la Pyrale du Mais. Ann. Instit. Past. 43, 1657-1678.

Paillot, A. 1933 L'infections chez les insectes. Imprimerie de Trevoux., 535 pp. (See page 134.)

\section{BACILLUS CANUS}

Insect concerned: The nun moth, Lymantria monacha.

Eckstein (1894) cultivated this organism from larvae of the nun moth during his studies on the bacteria assoclated with this insect.

Eckstein, K. 1894 Untersuchungen ther die in Raupen vorkommenden Bakterien. Z. f. Forst- und Jagdwesen, 26, 3-20, 228-241, 285-298, 413-424.

BACILLUS CAROTOVORUS

(See Erwinia aarotovora)

$\frac{\text { BAC ILLUS }}{\text { (See CELLULOSAM }} \frac{\text { FERMENTANS }}{\text { Clogtridium werneri Werner })}$ Werner 
BACILLUS CEREUS Frankland and Frankland (See Bacillus ellenbachi)

Insect concerned: Prodenia eridania.

Bacillus cereus was found by Babers (1938) to be the cause of a septicemia in seemingly normal larvae of the southern armyworm. It is described in Bergey's Manual (5th ed., p. 666).

Babers, F. H. 1938 A septicemia of the southern army worm caused by Bacillus cereus. Ann. Entomol. Soc. Amer., 3 I, $371-373$.

\section{BACILLUS CHOLERAE SUIS}

Insect concerned: The honey bee, Apis mellifera.

White (1906) isolated Bacillus cholerae suis from the intestine of the honey bee. The organism is described.

This organism, no doubt, is Salmonella choleraesuis Weldin (Bergey's Manual, 5th ed。, p. 440).

White, G. F. 1906 The bacteria of the apiary with special reference to bee diseases, U. S. Dept. Agr., Bur. Entomol., Tech. Bull. No. 14, 50 pp.

\section{BACILLUS CIRCULANS "Group"}

Insect concerned: The cecropia moth larva, Platysamia cecropia.

Steinhaus (1941) isolated a spore-forming bacillus which probably belongs to the Bacillus circulans group (see Bergey's Manual, 5th ed., page 678) from the caterpillar of the cecropia moth.

Steinhaus, E. A. 1941 A study of the bacteria associated with thirty species of insects. J. Bact., 42, 757-790.

\section{BAC ILLUS CLEON I Picard.}

Insects concerned: Temnorrhinus ( rhynchus mendicus.

While conducting his investigations on "coccobacilli" as insect parasites, Picard (1913) found a bacterium, which he provisionally named Bacillus cleoni, in the diseased. 
arvae of Temnorrhinus mendicus. He was not certain whether it was different from Bacillus (Coccobacillus) cajse (isolated from Arctia caja by Picard and Blanc (1913) or not. A year later Picard (1914) stated that Bacillus cleoni resembled Escherichia coli but that it differed in its power to liquefy gelatin.

* Picara, F. 1913 Le Cleonus mendicus et le Lixus scabricollis charancons nuisibles a la Betterave dans le midi de la France. Bull. Soc. d'Etude et de Vulgarisation zool. Agric., 12, 129-137.

Picard, F. 1914 Les insectes nuisible a la Betterave dang la midi de la France. La Vie Agric. et Rur., 3, $390-391$.

Picard, F. and BIane, G. R. 1913 Sur une septicemie baciliaire des chenilles d'Arctia caja I. Compt. rend. acad. sci.. 156, 1334-1336.

\section{BACILLUS CLOACAE Jordan \\ (See Aerobacter cloacae)}

\section{BACILLUS COERULEUS}

Insect concerned: The nun moth, Lymantria monacha,

Eckstein (IS9L) cultirated this organism from larvae of the nun moth. The 5 th edition of Bergey's Manual (pages 4 and 630) mentions two organisms by this name as members of groups of organisms which have not, received ouícient comparative study to justify delinite classiIcation, Inasmuch as these bacteria were described before 199:, Eckstein could very probably have considereà his organism to be either one of these.

Eckstein, $\tilde{L} .1894$ Untersuchungen ther die in Raupen vorkommender Bakterien. Z. F. Forst- und Jagdwesen, 26, 3-20, 228-241, 285-293, 413-424。

BACILLUS COLI Migula

(See Eischerichia coli)

BACILLUS COLI COMMUN IS Sternberg

(See Escherichia coli) 
BACILLUS CUBONIANUS Cuboni and Garbini

Insect concerned: The silkworm, Bombyx mori.

Cuboni and Garbini (1890) thought this bacillus was the cause of flacherie in silkworms. However, Paillot (1928) points out that it is possible to artificially infect silkworms with the bacillus and that the symptoms characteristic of flacherie are not present.

*Cuboni, C. and Garbini, A. 1890 Sopra una malattia del gelso in rappor,to Colla flaccidezza. $\mathrm{R}$. acad. dei Lincei, 2, Serie 4. Paillot, A. 1928 Les maladies due ver a soie-Grasserie et dysenteries, $328 \mathrm{pp}$. Editions due Service Photographique de I'Université Lyon. (See pp. 170-171.)

\section{BACILLUS CUENOTI Mercier}

Insect concerned: The oriental roach, Periplaneta orientalis.

Mercier (1907) studied in considerable detail the "bacteroids" found in the adipose tissues of the cockroach. He isolated a spore-forming rod which he thought was an intracellular microorganism and named it Bacillus cuenoti. More recent work, however, has shown that this bacillus is probably a contaminant and not identical with the intracellular microorganism found in the fat body of the cockroach. (See Hertig, 1921; Glaser, 1930, and Gier (quoted by steinhaus, 1940)).

Hertig, M. 1921 Attempts to cultivate the bacteroides of the Blattidae. Biol. Bull. Marine Biol. Lab., 4l, $181-187$.

Glaser, R. W. 1930 On the isolation, cultivation, and classification of the so-called intracellular "symbiont" or "Rickettsia" of Periplaneta americana. J. Expt. Med., $51,59-82$.

* Mercier, L. 1907 Recherches sur les bacteroides des Blattides. Arch. Protistenk., 2, 346-358.

Steinhaus, E. A. 1940 The microbiology of insects with special reference to the biologic relationships between bacteria and insects. Bact. Revs., 4, 17-57. 
Insect concerned: Vanessa urticae.

While studying the bacteria associated with the nun moth, Jymantria monacha, Eckstein (1894) found this bacillus in the larva of Vanessa urticae.

Eckstein, K. 1894 Untersuchungen ther die in Raupen vorkommenden Bakterien. Z. F. Forst- und Jagdwesen, 26, $3-20,228-241,285-298,413-424$.

\section{BAC ILLUS DOBELL I Duboscq and Grasse}

Insect concerned: The termite, Glyptotermes iridipennis.

According to Dougherty (1942), Duboscq and Grasse (1927) recorded three bacteria from Calotermes (Glyptotermes) iridipennis: Fusiformis termitidis, Fusiformis hilli and Bacillus (Flexilis) dobelli. Dougherty states that for this last bacterium Duboscq and Grasse "proposed the group name (subgenus?) Flexilis to include certain bacilli characterized by a considerable length (up to 250 microns)."

Dougherty, E. C. 1942 Unpublished manuscript. *Duboscq, 0., and Grasse, P. 1927 Flagelles et schizophytes de Calotermes (Glyptotermes) iridipennis Frogg. Arch. Zool. Exp. Gen., 66, 451-496.

\section{BACILLUS E White}

Insect concerned: The honey bee, Apis mellifera.

White (1906) isolated Bacillus E from the honey bee while studying its intestinal flora. He gives a description of this organism.

*White, G, F. 1906 The bacteria of the apiary with special reference to bee diseases. U. S。 Dept. Agr.,

Bur. Entomol., Tech. Bull. No. 14, 50 pp.

\section{BACILLUS ELLENBACHI}

Insect concerned: The silkworm, Bombyx mori. 
Sawamura (1906) lists this bacillus as one which produced "flacherie by multiplying in the body of the silkworm." Bacillus Ellenbachi is probably a synonym for Bacillus cereus.

Sawamura, S. 1906 Note on bacteria pathogenic to silkworm. Tokyo Imp. Univ. Coll. Agr. Bull., 1, 105.

\section{BACILLUS ENTOMOTOXICON DUggar}

Insects concerned: The squash-bug, Anasa tristis; the chinch-bug, Blissus leucopterus; the box-elder bug, Leptocoris trivittatus; and larvae of the white-lined morning sphinx, Deilephila lineata; Lachnosterna fusca; and a tomato worm (Protoparce).

This bacillus, which Duggar (1896) named Bacillus entomotoxicon, was found by him to be the cause of a disease of the squash-bug, Anasa tristis. Both laboratory and field experiments showed the disease to be easily transmissable to healthy squash-bugs by contact with pure cultures of the organism of the fluids of infected insects, nymphs being more readily infected than adults. Infusions made from the growth of this organism on agar contained an active principle which "kills many insects after a very short period of immersion." While young chinch-bugs (Blissus leucopterus) were also susceptible to the infection, adult chinch-bugs were strongly resistant, as were the grubs and larvae listed above.

Since Duggar describes this bacterium as not producing spores, the generic name Bacillus would be a misnomer according to present day nomenclature.

Dugger, B. M. 1896 On a bacterial disease of the squashbug (Anasa tristis DeG.). Bull. Illinois State Lab. Natural History, ㄴ, 340-379.

\section{BACILLUS EQUIDISTANS NoguchI}

Tick concerned: The wood tick, Dermacentor andersoni.

Noguchi (1926) isolated this bacillus and two others from the spotted fever tick, Dermacentor andersoni. He described its cultural characteristics in detall. The bacterium is not a spore-former, hence, it is unfortunate that Noguchi gave it the generic name "Bacillus." 
*Noguchi, H. 1926 Cultivation of rickettsia-like microorganisms from the Rocky Mountain spotted fever tick, Dermacentor andersoni. J. Exptl. Med., 43, 515-532.

\section{BACILLUS FERRUGENUS}

Insect concerned: The silkworm, Bombyx mori.

Sawamura (1906) lists Bacillus ferrugenus (B. ferrugineus?) as an organism experimentally pathogenic to the silkworm.

Sawamura, S. 1906 Note on bacteria pathogenic to silkworm. Tokyo Imp. Univ. Coll. Agr. Bull., I, 105.

\section{BAC ILLUS FLAVUS}

Insect concerned: Vanessa polychlorus.

While studying the bacteria associated with the nun moth, Lymantria monacha, Eckstein (1894) found Bacillus flavus in dead larvae of Vanessa polychlorus. Apparently this is neither one of the two organisms mentioned in Bergey's Manual (5th ed., 1939, pp. 528 and 648) by the name Bacillus flavus as both of these were described after 1894.

Eckstein, K. 1894 Untersuchungen thber die in Raupen vorkommenden Bakterien. Z. f. Forst- und Jagdwesen, 26, 3-20, 228-241, 285-298, 413-424.

\section{BACILLUS FLEX ILIS DobelI}

Insect concerned: The crane-fly, Tipula sp.

In his examinations of crane-fly larvae for protozoa, Mackinnon (1912) observed large numbers of bacteria. He states: "Chief among them is a large sinuous form resembling Bacillus flexilis Dobell."

Mackinnon, D. L. 1912 Protists parasitic in the larva of the crane-fly, Tipula sp. Parasitol., 5, 175-189. 


\section{BACILLUS FOETIDUS}

Insect concerned: Vanessa urticae.

Eckstein (1894) found this bacillus along with Bacillus lineatus and Bacillus similis, in dead larvae of Vanessa urticae.

According to Lehmann-Neumann-Breed (1931) the name "B. foetidus" must be rejected, and they accept the name Bacillus verrucosus, which is listed in Bergey's Manual, 5th ed., p. 789 .

Eckstein, K. 1894 Untersuchungen ther die in Raupen vorkommenden Bakterien. Z. f. Forst- und Jagdwesen, 26, 3-20, 228-241, 285-298, 413-424.

Lehmann-Neumann-Breed 1931 Determinative Bacteriology, Vol. II, G. E. Stechert and Co., New York, 868 pp.

\section{BACILLUS FUCHSINUS Boekhaut and De Vries}

Insect concerned: The silkworm, Bombyx mori.

Sawamura (1906) lists this organism as one experimentally pathogenic to the silkworm. It is probably synonymous with Serratia fuchsina.

Sawamura, S. 1906 Note on bacteria pathogenic to silkworm. Tokyo Imp. Univ. Coll. Agr. Bull., I, 105.

BACILLUS GASTRICUS Ford (See Bacillus subgastricus)

\section{BACILLUS GAYTON I Cheshire}

Insect concerned: The honey bee, Apis mellifera.

White (1906) refers to Bacillus gaytoni by stating: "It is believed by some bee keepers that Bacillus gaytoni of Cheshire is the cause of bee paralysis, but this is not claimed by Cheshire, and the belief is not grounded on bacteriological findings."

White, G. F. 1906 The bacteria of the Apiary with special reference to bee diseases. U. S. Dept. Agri., -Bur. Entomol., Tech. Bull. No. 14, 50 pp. 
(See Coccobacillus gibsoni)

Insect concerned: The corn borer, Pyrausta nubilalis.

According to Paillot (1933) Chorine isolated this organism from the corn borer in 1929 and found it to be pathogenic. This is apparently the same organism that Chorine isolated in 1929 and called Coccobacillus gibsoni (which see). Paillot says the organism is a spore former but in Chorine's (1929a, b) original articles, he states that the organism is non-sporulated, hence the generic name Bacillus would not be applicable.

*Chorine, V. 1929 New bacteria pathogenic to the larvae of Pyrausta nubilalis Hb. Internat. Corn Borer Invest., Sci. Repts., 2, 39-53.

* Chorine, V. 1929 Nouveaux microbes pathogenes pour

les chenilles de la Pyrale du Mais, Ann. Inst. Pasteur, 43, 1657-1678.

Paillot, A. 1933 L'infections chev les insectes, 535 pp. Imprimerie de Trevoux., Paris. (See page 134.)

\section{BACILLUS GIGAS Goot}

Insect concerned: Adoretus compressus.

According to Goot (1915) Adoretus compressus is attacked both in the larval and adult stages by Bacillus gigas. He found that it destroyed large numbers of the larvae in the insectary.

* Goot, 0. 1915 Ueber einige engerlingensoorten, die in riettuinen voorkomen. Med. Proefatation voor de Java Suikerindustrie, pt. 5, No. 10, 60 pp.

\section{BACILLUS GORTYNAE Paillot}

Insects concerned: Gortyna ochracea; the gypsy moth, Iymantria dispar.

Paillot (1913) discovered this bacillus in the caterpillars of Gortyna ochracea. It had been the cause of an epidemic among them. The insects lost all use of their legs with the exception of the first pair, and the posterior part of the body seemed to have lost all sensation. Microscopic examination of the blood showed a great many 
motile "coccobacilli," often paired in two's, some in the coccus form and others rod-shaped. After the larvae died of a septicemia, the body quickly decomposed.

* Paillot, A. 1913 Coccobacilles parasites d'Insectes. Compt. rend. acad. sci., 157, 608-611.

$$
\text { BACILLUS GRAPHITOSIS }
$$

(See Bacillus tracheitis sive graphitosis)

\section{BACILLUS GRYLLOTALPAE Metalnikov and Meng}

Insect concerned: Gryllotalpa gryllotalpa (vulgaris, Latr.)

This bacillus was one of two bacteria which were found to be the cause of the death of Gryllotalpa gryllotalpa in the laboratory. Bacterium gryllatalpae (which see) was the other organism.

*Metalnikor, S., and Meng, L. Y. 1935 Utilisation des microbes contre les courtillieres. Compt. rend. acad. sci., 201, 367-368.

\section{BACILLUS HOPLOSTERNUS Paillot}

Insects concerned: Nygmia phaeorrhea (Euproctis chrysorrhoea); the cockchafer, Melolontha melolontha; Malacosoma neustria; Arctia (chelonia) caja; Vanessa urticae; P.orthetria (Lymantria) dispar.

Paillot (1919) found Bacillus hoplosternus, which he had isolated from diseased cockchafers, to be very pathogenic for Nygmia phaeorrhea. The insects died within 24 hours after being inoculated. He found the same thing to be true with Malacosoma neutria, Arctia caja, and Vanessa urticae. In the case of the last two insects, Paillot found the blood at death contained few bacteria, and concluded that the bacillus is chiefly pathogenic because of a toxin it secretes. Porthetria dispar showed a decided immunity to the bacillus. Paillot (1933) has discussed in quite some detail the cytology of Bacillus hoplosternus.

* Paillot, A. 1919 Contribution a l'etude les parasites microbiens des insectes. Etude de Bacillus hoplosternus (Paillot). Ann. Inst. Past., 33, 403-419.

Paillot, A. 1933 L'infection chez les insectes, $535 \mathrm{pp}$. Imprimerie de Trevoux, Paris. (See pp. 154-156, and others.) 


\section{BACILLUS IMMOBILIS Steinhaus}

Insect concerned: Ceratomia catalpae.

The rectum of larvae of Ceratomia catalpae. was found by steinhaus (1941) to contain this non-motile spore-forming bacillus.

* Steinhaus, E. A. 1941 A study of the bacteria associated with thirty species of insects. J. Bact., 42 , 757-790.

BACILLUS INSECTORUM Burrell [Burrill]

(See Micrococcus insectorum)

BAC ILLUS LACTIS AEROGENES Sternberg

(See Aerobacter aerogenes)

\section{BACILLUS LANCEOLATUS}

insect concerned: The honey bee, Apis mellifera.

Mattes, (1927) indicated that Bacillus lanceolatus caused a mild foulbrood of bees:

"In seiner Bacillus agilis Gestalt ahnelt er sehr dem Bacillus lanceolatus, der bei der

'Gustartigen Faulbrut der Bienen' neben anderen

Formen auftritt."

He mentioned the fact that this bacillus was similar to Bacilius agilis Mattes and Lehmann-Neumann-Breed (1931) refer to it as being lancet-shaped.

Lehmann-Neumann-Breed 1931 Determinative Bacteriology,

G. E. Stechert and Co., New York, 868 pp.

*Mattes, 0. 1927 Parasiture Krankheiten der Mehlmottenlarven und Versuche liber ihre Verwendbarkeit als biologisches Bekampfungsmittel. Sitzungsberichte der Gesellschaft zur Bedfordemung der gesamten Naturwissenchaften zu Marburg, 62, 381-417.

\section{BACILLUS LARVAE White}

(Bacillus brandenturgionsis and Bacillus burri) 
White (1904) cultured on special media the above organism which he and others had found to be the cause of American foulbrood in bees. Pending more definite information in regard to the bacterium, he temporarily called it Bacillus "X", later (1905, 1906) naming it Bacillus larvae. He states that Bacillus brandenburgiensis and Bacillus burri are other names that have been used for the same species. See White (1920) for a complete description of the organism.

White, G. F. 1904 The further investigation of the diseases affecting the apiaries in the State of New York. New York Dept. Agr. Ilth Ann. Rept. Com. Agr. for 1903, p. 103-114. Jan. 15 .

White, G. F. 1905 The bacterial flora of the apiary with special reference to bee diseases. Thesis. Cornell

University, Ithaca, N. Y.

White, G. F. 1906 The bacteria of the apiary, with special reference to bee diseases. U. S. Dept. Agr., Bur. Entomol., Bull. \#l4, 50 pp.

White, G. F. 1920 Anerican Foulbrood, U. S. Dept. Agri. Bull. $809,46 \mathrm{pp}$.

\section{BACILLUS LASIOCAMPA Brown}

Insect concerned: The tent caterpillar moth, Malacasoma americana.

Brown (1927) found Bacillus lasiocampa throughout the entire female genital system (ovaries and egg tubes) of the tent caterpillar moth and he readily cultivated it from the dissected organs. The females infected with this spore-forming bacillus seemed unable to deposit their eggs, though the organism was not found in the eggs. However, Alcaligines stevensae (which see) was present. A complete description of Bacillus lasiocampa is given by Brown.

* Brown, F. M. 1927 Descriptions of new bacteria found in insects. Amer. Mus. Novitates, No. 251, 11 pp.

BACILLUS LATHYRI Manns and Taubenhaus (Erwinia lathyri)

Insect concerned: Aphis rumicis.

Needham (1937.) isolated from diseased Aphis rumicis an organism culturally resembling Bacillus lathyri. The same bacillus was not found in uninfected aphids. 
Bscillus lathyri was first isolated from diseased sweet peas. According to Bergey's Manual (5th ed., p. 413) it is now called Erwinia lathyri.

Needhan, N. Y. 1927 A bacterial disease of Aphis rumicus Linr. , apparently caused by Bacillus lathyri Manns and Taubenhaus. Ann. Appl. Biol., 24, 144-147.

\section{BACILLUS LENTIMORBUS DutKy}

Insect concerned: The Japanese beetle, Popillia japonica.

Dutky (1940) found Bacillus lentimorbus to be the cause of "type B" milky disease of Japanese beetle larvae, The "type A" disease was caused by an organism he named Bacillus popilliae. Dutky describes both organisms and the diseases they cause. He was unable to artificially culture Bacillus lentimorbus.

*Dutky, S. R. 1940 Two new spore-forming bacteria causing milky diseases of Japanese beetle larvae. J. Agr. Research, 61, 57-68.

\section{BAC ILLUS LEFT INOTARSE White}

Insect concerned: The Colorado potato beetle, Leptinotarsa decemlineata.

White (1928) found this organism to be pathogenic for the larvae of Leptinotarsa decemlineata. The disease is characterized by a septicemia and the bacillus may be found in the larval blood. The infected larvae are found clinging to the potato plant; the dead ones are usually on the ground. In a later report, White (1935) stated that this organism was similar to Bacillus sphingidis and Bacillus noctuarun.

*White, G. F. 1928 Potato beetle septicemia, with the proposal of a new species of bacterium. Proc. Ent. Soc. Wash., 30, 69-70.

White, G. F. 1935 Potato beetle septicemia, J. Agr, Research, 51, 223-234. 
Insects concerned: The nun moth, Lymantria monacha; Vanessa urticae; Porthesia auriflua; and Liparis salicis.

This organism was among those found in larvae of the nun moth by Eckstein (1894). He also isolated this organism from dead Vanessa urticae, Porthesia auriflua, and Liparis salicis.

Eckstein, K. 1894 Untersuchungen thber die in Raupen vorkommenden Bakterien. Z. f. Forst- und Jagdwesen, 26, 3-20, 228-241, 285-298, and 413-424.

\section{BACILLUS LIPARIS Paillot}

Insect concerned: The grpsy moth, Porthetria (Lymantria) dispar.

Paillot (1917) isolated Bacillus liparis from larvae of Porthetria (Lymantria) dispar. He found it to be very pleonorphic and to resemble the diphtheria bacillus in morphology. The bacillus appeared to be of little pathogenic importance.

* Paillot, A. 1917 Microbes nouveaux parasites des chenilles de Lymantria dispar. Compt. rend. hebdom. Séances Acad. Sci., I64, 525-527.

Paillot, A. 1933 L'infection chez les insectes, 535 pp. Imprimerie de Trevoux., Paris. (See page 140.)

\section{BACILLUS LUTZAE Brown}

Insects concerned: The green fly, Lucilia sericata; the house fly, Musca domesticà.

Brown (1927) isolated this spore-forming bacillus from dying and dead green flies (Lucilia sericata) and found it to be pathogenic for the housefly also. Dying individuals and those just dead but showing no sign of decay, yielded pure cultures. Those in decay yielded a mold and two cocci. (See Micrococcus rushmori and Neisseria luciliarum.) This organism is a rather small "coccobacillus" bearing a polar spore. A complete description of the bacillus is given by Brown.

* Brown, F. M. 1927 Descriptions of new bacteria found

in insects. Amer. Mus. Novitates, No. 25l, 11 pp. 
(See Coccobacillus lymantriae)

Insect concerned: The gypsy moth, Porthetria (Lymantria) dispar.

Picard and Blanc (1913) discovered a fatal septicemia occurring in the larva of the gypsy moth to be caused by an organism which they called Coccobacillus lymantria. Paillot (1933), however, refers to "Bacillus (Bacterium) lymantriae Picard and Blanc." Apparently the organisms are the same.

Paillot, A. 1933 L'infections chez les insectes, 525 pp. Imprimerie de Trevoux, Paris. (See page 125.) * Picard, F., and Blanc, G. R. 1913 Les infections a coccobacilles chez les insectes. Compt. rend. hebdom. acad. sci., 157, 79-81.

\section{BACILLUS LYYMANTRIAE BETA Paillot}

Insect concerned: The gypsy moth, Porthetria (Lymantria) dispar.

Paillot (1919) isolated Bacillus lymantriae beta and Bacillus lymantricola adiposus from larvae of Porthetria (Lymantria) dispar infected with a septicemia, He states that one is not to confuse Bacillus lymantriae beta with the Bacillus lymantriae (see above) of Picard and Blanc, which he says, should be called Bacillus lymantriae alpha. Paillot pointed out that the cultural characteristics of the two organisms were different.

* Paillot, A. 1919 La pseudograseerie, maladie nouvelle des chenilles de Lymantria dispar. Compt. rend. acad. sci., 168, 258-260.

\section{BACILLUS LYMANTRICOLA ADIPOSUS Paillot.}

Insects concerned: The gypsy moth, Porthetria (Lymantria) dispar; Vanessa urticae; the brown-tail moth, Euproctis chrysorrhea; and the silkworm, Sericaria mori.

Paillot (1919) isolated Bacillus lymantricola adiposus from the diseased larvae of Porthetria (Lymantria) dispar, which presented the external symptoms of grasserie and 
flacherie. He was able to reproduce the same symptoms experimentally in the gypsy moth, and also in the caterpiliars of Vanessa urticae and Euproctis chrysorrhea. A brief description of the morphology and cultural characteristics of the organism are given by Paillot. He named this bacterium, which he says is a coccobacillus, Bacillus lymantricola adiposus, because of its specific "désorganisation" action on the adipose tissue of Porthetria (Iymantria) dispar. Paillot (1933) goes into quite some detail in discussing the morphological variations of this organism.

* Paillot, A. 1919 La pseudograsserie maladie nouvelle des chenilles de Lynantria dispar. Compt. rend. acad. sci., 168, 258-260.

Paillot, A. 1933 L'infection chez les insectes, 535 pp. Imprimerie de Trevoux, Paris.

\section{BAC ILLUS MEGATHER IUM De Bary}

Insect concerned: Lecanium corni.

Benedek and Specht (1933) found the secondary "symbiont" in diseased Lecaniidae to be Bacillus megatherium, the main "symbiont" being a fungus, Torula lecanii cornii n. sp. Both organisms were found free in the hemolymph of the host. See Bergey's Manual of Determinative Bacteriology, 5th edition, page 665, for a complete description of Bacillus megatherium, which is widely distributed in the air, soil, and putrifying material.

Benedek, T., and Specht, G. 1933 Mykologischbakteriologische Untersuchungen Uber Pilze und Bakterien als Symbionten Derbtieren. Zent. f. Bakt. (I。orig.), 130, 74-90.

\section{BACILLUS MEGATERIUM BOMBYCIS}

Insect concerned: The silkworm, Bombyx mori.

Sawamura (1906) lists this organism as one artificially pathogenic to the silkworm. The name "megaterium" is probably a misspelling of megatherium.

Sawamura, S. 1906 Note on bacteria pathogenic to silkworm. Tokyo Imp. Univ. Coll. Agr. Bull., 1, 105. 


\section{BACILLUS MELOLONTHAE Chatton}

Insects concerned: The cockchafer, Melolontha melolontha; the silkworm, Bombyx mori; the gypsy moth, Porthetria (Lymantria) dispar; and Vanessa urticae.

In experimenting with Coccobacillus acridiorum on cockchafers, Chatton (1913) noted a septicemia independent of Coccobacillus acridiorum which he found due to Bacillus melolonthae. The organism resembles Coccobacillus acridiorium but is different in that it imparts a fluorescence to the medium in 5 to 6 days. This organism behaved the same way in both the silkworm and the cockchafer, being virulent when injected and innocuous when taken into the alimentary tract.

For the action of the organism on Porthetria (Lymantria) dispar and Vanessa urticae see Paillot (1916).

* Chatton, E. 191.3 Septicemies spontanees a coccobacilles chez le. Hanneton et le Ver-a-soie. Compt. rend. acad. sci., 156, 1707, 1709.

Paillot, A. 1916 Les coccobacilles due Hanneton. Action pathogene sur quelques chenilles de macrolépidopteres. Compt. rend. soc. biol., 79, 1102-1103.

\section{BACILLUS MELOLONTHAE LIQUEFACIENS ALPHA Paillot}

Insect concerned: The cockchafer, Melolontha melolontha.

Paillot (1918, 1922) isolated three strains (alpha, beta, and gamma) of Bacillus melolonthae liquefaciens from diseased cockchafers. At various times he isolated 8 other bacteria from the same source, the organism causing the cockchafer infection varying with the locality. The insects die from a septicemia, characterized by noncoagulability of the blood, which also becomes more or less turbid. The three strains of Bacillus melolonthae liquefaciens are all gram negative, and vary greatly in their morphologies. (See Paillot, 1933).

* Paillot, A. 1918 Coccobacillus nouveux parasites du Hanneton. Compt. rend. hebdom. acad. sci., 167, 10461048.

* Paillot, A. 1922 Les maladies bactériennes des insectes. Utilsation en agriculture des bacteries entomophytes.

Ann. Epiphyt., ㅇ, 95-291.

Paillot, A. 1933 L'infection chez les insectes. $535 \mathrm{pp}$.

Imprimerie de Trevoux, Paris. 
BACILLUS MELOLONTHAE LIQUEFACIENS BETA Paillot (See Bacillus melolonthae liquefaciens alpha.)

BAC ILLUS MELOLONTHAE LIQUEFACIENS GAMMA Paillot (See Bacillus melolonthae liquefaciens alpha.)

BAC ILLUS MELOLONTHAE NON-LIQUEFACIENS ALPHA Paillot

Insects concerned: The cockchafer, Melolontha melolontha; the gypsy moth, Porthetria (Lymantria) dispar; and the brown-tail moth, Euproctis chrysorrhoea.

Paillot (1918) isolated this organism, along with the beta, gamma, delta, and epsilon strains, from diseased cockchafers. He (1919) conducted experiments with the gypsy moth and the brown-tail moth using Bacillus melolonthae liquefaciens alpha and found both insects to be immune.

Paillot differentiated between Bacillus melolonthae liquefaciens and strains and Bacillus melolonthae nonliquefaciens and strains by their ability to liquefy gelatin. $\mathrm{He}$ (1933) discusses in considerable detail the pathogenic action and immunity produced by the different strains of Bacillus non-liquefaciens.

* Paillot, A. 1918 Coccobacillus nouveux parasites du Hanneton. Compt. rend. hebdom. acad. sci., 167, 1046-1048.

Paillot, A. 1919 La Karyokynetose, nouvelle reaction d'immunité naturelle observée chez les chenilles de macrolepidopteres. Compt. rend. hebdom. acad. sci., $169,396-398$.

Paillot, A. 1922 Les maladies bacteriennes des insectes. Utilisation en agriculture des bactéries entomophytes. Ann. Epiphyt. , 8, 95-291.

Paillot, A. 1933 L'infection chez les insectes., 535 pp., Imprimerie de Trévoux, Paris. (See pp. 303-304; 249278 , and others.)

BACILLUS MELOLONTHAE NON-LIQUEFACIENS BETA Paillot (See Bacillus melolonthae non-liquefaciens alpha.) 
BAC ILLUS MELOLONTHAE NON-LIQUEFACIENS DELTA Paillot (See Bacillus melolonthae non-liquefaciens alpha.)

BACILLUS MELOLONTHAE NON-LIQUEFACIENS EPSILON Paillot (See Bacillus melolonthae non-liquefaciens alpha.)

BAC ILLUS MESENTERICUS Trevisan

Insects and ticks concerned: The honey bee, Apis mellifera; the bedbug, Cimex lectularius; Stomoxys calcitrans; Rhodnius prolixus; and the ticks, Argas persicus and Ornithodoros moubata.

In attempting to determine the cause of "blackbrood" in bees, Serbinow (1912) isolated Bacillus mesentericus, which is widely distributed in soil and dust.

Duncan (1926) found "B. mesentericus" and "B. vulgatus"l

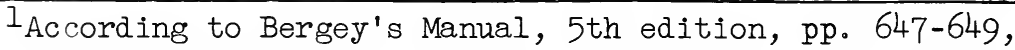
Bacillus vulgatus is considered synonymous with Bacillus mesentericus.

to be susceptible to the bactericidal principle in the gutcontents of Argas persicus, Ornithodoros moubata, Stomoxys calcitrans, Cimex lectularius, and Rhodnius prolixus. For a complete description of this organism see the Bergey Manual, 5th edition, p. 647.

Duncan, J. T. 1926 On a bactericidal principle present

in the alimentary canal of insects and arachnids.

Parasitol., 13, 238-252.

Serbinow, I. L. 1912 Chernaia cherva. Blackbrood in

bees. Vestnik Russkavo obstschestva pchelovodstva,

No. 11, pp. $426-429$.

\section{BAC ILLUS MILLII Howard}

Insect concerned: The honey bee, Apis mellifera.

Howard (1900) reported a new bee disease and called it "New York bee disease" or "black brood." He gave as its cause an organism, which he called Bacillus millii.

White (1906) is of the opinion that "New York bee disease" is really genuine European foulbrood, caused by Bacillus alvei. He states: "In our investigations of 
this diseased condition "New York bee disease", which have covered five years, we have not found an organism corresponding to Bacillus millii in any of the specimens that we have received; but we have found Bacillus alvei . . ."

Howard, Wm. R. 1900 New York bee disease, or Black Brood. Gleaninsis in Bee Culture, Feb. 15.

White, G. F. 1906 The bacteria of the apiary with special reference to bee diseases. U. S. Dept. Agri., Bur.

Entomol., Tech. Bull. No. 14, 50 pp.

\section{BACILLUS MINIMUS}

Insects concerned: The nun moth, Lymantria monacha, and Liparis salicis.

Fckstein (1894) found this bacillus, which he isolated from the larva of the nun moth, to be pathogenic for the larvae of Liparis salicis.

Eckstein, K. 1894 Untersuchungen lber die in Raupen vorkommenden Bakterien. Z. f. Forst- und Jagdwesen, 26, 3-20, 228-241, 285-298, 413-424.

\section{BACILLUS MONACHAE (von Tubeuf) Eckstein}

(See Bacterium monachae and Bacillus $\underline{B}$ )

Insects concerned: The nun moth, Iymantria monacha;

Vanessa urticae; Porthesia auriflua; Trachia piniperda; Pieris brassicae; and the satin moth, Stilpnotia (Liparis) salicis; Hyponomenta evonymella.

Eckstein (1894) believed this spore-forming organism to be identical to Bacterium monachae of von Tubeuf (1892a and $\mathrm{b})$ and Bacillus $\underline{\mathrm{B}}$ of Hofmann (1891). Eckstein isolated Bacillus monachae from sick nun moth larvae. He found it to be pathogenic to the larvae of Vanessa urticae and Porthesia auriflua, and to be occasionally pathogenic for the larvae of Trachea piniperda, Pieris brassicae, and Stilpnotia (Iiparis) salicis. It was not pathogenic for Hyponomenta evonymella.

*Eckstein, K. 1894 Untersuchungen Hber die in Raupen vorkommenden Bakterien. Z. f. Forst- und Jagdwesen, 26, 3-20, 228-241, 285-298, 413-424. 
Hofmann, 0. 1891 Die Schlaffsucht (Flacherie) der Nonne (Liparis monacha) nebst einem Anhang. Insektent8tende Pilze mit besonderer Beruchsichtigung der Nonne. $31 \mathrm{pp}$. P. Weber, Frankfurt a. M.

v. Tubeuf, C. $1892 a$ Die Krankheiten der Nonne (Liparis

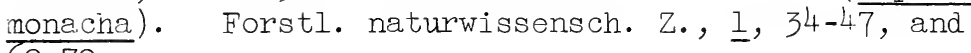
62-79.

v. Tubeuf, C. 1892b Weitere Beobachtungen uber die Krankheiten der Nonne. Forstl. Naturwissensch. Z., I, $277-279$.

\section{BACILLUS MYCOIDES FIHgge}

Insects and ticks concerned: The silkworm, Bombyx mori; the honey bee, Apis mellifera; Orgyia pudibunda; Stomoxys calcitrans; Cimex lectularius; Rhodnius prolixus; and the ticks, Argas persicus and Ornithodoros moubata.

This spore-forming bacillus was originally described by Flugge and is widely distributed in the soil. It was in such an asscciation that it was cultivated by Eckstein (1894) who isolated it from soil containing dead larvae of Oryjia pudibunda which had been stored thus for a period of two years,

White (1906) isolated Bacterium mycoides from the intestine of a healthy honey bee. Since the organism he isolated was a spore-former, it was probably Bacillus mycoides.

Sawamura (1906) lists Bacillus mycoides as artificially pathogenic to the silkworm, Bombyx mori.

After feeding $\underline{B}$. mycoides to Argas persicus, Hindle and Duncan (1925) found that the bacillus neither survived long in the tick nor appeared in its feces. Unlike Bacillus subtilis, $\underline{B}$. mycoides was either not or only slightly effected by the bactericidal gut-contents of Argas persicus, Ornithodoros moubata, Stomoxys calcitrans, Cimex lectularius, and Rhodnius prolixus (Duncan, 1926).

For a description of this organism see Bergey's Manual, 5 th edition, p. 664.

Duncan, J. T. 1926 On a bactericidal principle present in the alimentary canal of insects and arachnids.

Parasitol., 18, 238-252.

Eckstein, K. $\overline{18} 94$ Untersuchungen ther die in Raupen vorkommenden Bakterien. Z. f. Forst- und Jagdwesen, 26, 3-20, 228-241, 285-298, 413-424. Hindle, E., and Duncan, J. T. 1925 The viability of bacteria in Argas persicus. Parasitol., 17, 434-446. 
Sawamura, S. 1906 Note on bacteria pathogenic to silkworm. Tokyo Imp. Univ. Coll. Agr. Bull., 7, 105.

White, G. F. 1906 The bacteria of the apiary with special reference to bee diseases. U. S. Dept. Agri., Bur. Entomol., Tech. Bull., No. 14, 50 pp.

BACILLUS NEUROTOMAE Paillot

(See Bacterium neurotomae)

Insect concerned: Neurotoma nemoralis.

This bacillus was isolated from diseased Neurotoma nemoralis by Paillot (1924). It was not found to be of any practical importance in checking their numbers in nature.

* Paillot, A. 1924 Sur deux Bacteries parasites des larves de Neurotoma nemoralis. Compt. rend. hebdom. acad. sci, $178,246-249$.

BAC ILLUS NOCTUARUM White (See Bacillus sphingidis White)

Insects concerned: Feltia annexa; Feltia ducens; Porosagrotis orthogonia; Prodenia ornithogallis; Euxoa spp. (Noctuidae); Euxoa ochrogaster.

The 5th edition of Bergey's Manual (page 605) states: "An organism causing cutworm septicemia with characters identical with Bacillus sphingidis is Bacillus noctuarum White." In the original reference to the organism White (1923) remarks on the similarities of these two bacteria: "The bacillus closely resembles $\underline{B}$. sphingidis as regards its reaction to environment and the methods and results of inoculation." In all probability these two organisms are enough alike in their characteristics to be considered the same species.

Bacillus noctuarum has also been known by the names Escherichia noctuarii (Bergey's Manual, 3rd ed., 1930, p. 327) and Proteus noctuarum (Bergey's Manual, 4th ed., 1934, p. 363).

This bacillus causes a septicemia in the insect species listed above. King and Atkinson (1928) found a distinct similarity between the regular cutworm septicemia caused by Bacillus noctuarum and a septicemia in the red-backed cutworm, Euxoa ochrogaster. 
Ting, K. M. anc Atkinson, N. J. 1928 The biological control factors of the immature stages of Euxoa ochrogaster, Gn. (Lepidoptera, Phalaenidae) in Saskatchewan, Ann. Entomol. Soc. A er., 2l, 167-188. *White, G. F. 1923 Cutworm septicemia. J. Agri. Research., 26, 487-496.

BACILLUS OBLONGUS

Insect concerned: Hyponomenta evonymella.

Eckstein (1894) found this bacillus present in the larvae of Hyponomenta evonymella.

Eckstein, K. 1894 Untersuchungen ther die in Raupen vorkommenden Bakterien. Z. f. Forst- und Jagdwesen, 26, 3-20, 228-241, 285-298, 413-424.

$\frac{\text { BAC ILLUS OCHRACEUM }}{\text { (See Bacterium Ochraceum. }}$

BACILLUS ONTARION I Chorine

(See Bacterium ontarioni)

Insect concorned: The corn borer, Pyrausta nubilalis.

Chorine (1929) isolated this organism from the corn borer and called it Bacterium ontarioni, but Paillot (1933) calls it Bacillus ontarioni. Since it is a sporeforming bacillus, the correct generic name would be Bacillus.

*Chorine, V. 1929 New bacteria pathogenic to the larvae of Pyrausta nubilalis Hb. Internat. Corn Boror Invest., 2., 39-53.

Paíllot, A. 1933 L'infections chez les insectes, $535 \mathrm{pp}$. Imprimerie de Trevous, Paris. (See page 134.)

\section{BACILLUS ORPHEUS}

Insect concerned: The honey bee, Apis mellifera.

White (1912) found a bacterium, which he named Bacillus orpheus, occasionally associated with European foulbrood. He found it very widely spread in one apiary causing heavy 
losses. McCray (1917) has given a description of the organism.

McCray, A. H. 1917 Spore-forming bacteria of the apiary. U. S. Dept. Agr. Jour. of Agr. Research, 1 , No. 11, p. 399.

White, G. F. 1912 The cause of European Foulbrood. U. S. Dept. Agr. Bur. Entomol., Cir. 157.

\section{BAC ILLUS PARALVEI Burnside}

Insect concerned: The honey bee, Apis mellifera.

Burnside (1932) and Burnside and Foster (1935) found this organism in diseased colonies of bees in Southeastern United States. According to the 5th edition of Bergey's Manual (which see for a complete description of the organism), the disease resembles European foulbrood, but some of the dead larvae and pupae resemble those of American soulbrood. Some of the insects remain dark brown with ropiness. Many infected colonies have been known to recover. Bacillus paralvei resembles the organisms that cause European foulbrood.

Burnside, C. E. 1932 Amer. Bee J., 62, 433. Burnside, C. E., and Foster, R. E. 1935 Studies on the bacteria associated with parafoulbrood. J. Econ. Enitomol., 28, 578-584.

\section{BACILLUS PARATYPHUS ALVEI Bahr} (See Salmonella schbttmulleri var. alvei Hauduroy et al.)

Insect concerned: The honey bee, Apis mellifera.

In the vicinity of Copenhagen an acute enteritis of bees was found to be due to Bacillus paratyphi alvei (Bahr, 1919). The bees usually died in 25 hours to a few days. The organism, however, is not identical with the forms of Salmonella paratyphi found in man and domestic animals. The 5th edition of Bergey's Manual (page 461) lists the organism as Salmonella schbttmulleri var. alvei Hauduroy et al.

*Bahr, L. 1919 Paratyphus nos Honningbien. Skandinavisk Veterinar--Tidskrift, 2, 25-40 and 45-60. Hauduroy et al., Dict. d. Bact. Path., 1937, 469. 
Insect concerned: Pectinophora gossypielia.

In the summer of 1932, White and Noble (1936) encountered a septicemia among pink bollworm larvae, which they found to be caused by Bacillus pectinophorae. The disease was observed only under laboratory conditions and had not been noted in the field.

White and Noble state, "Metalnikov and Metalnikov (1932, 1933) studying diseases of the pink bollworm, report a mortality of 90-99 per cent from natural infection in the field in 1932 and 1933. It is seen from the description of the microorganisms which they encountered that they were not working with pink bollworm septicemia." Bacillus, as a generic name, is not according to present day nomenclature inasmuch as the bacterium is a small: non-sporeforming rod.

Metalnikov, S., and Metalnikov, S. S. 1932 Maladies des vers du caton (Gelechia gossypiella et Prodenia litura). Compt. rend. acad. agr. $, 18,203-207$.

Metalnikov, S., and Metalnikov, S. S. 1933 Utilisation des bactéries dans la eutte contre les insectes nuisibles aux catonniers. Compt. rend. soc. biol., 113, 169-172. *White, C. F., and Noble, L. W. 1936 Notes on pirk bollworm septicemia. J. Econ. Entomol., 29, 122-124.

\section{BACILLUS PEDICULI Arkwright and Bacot}

Insect concerned: Pediculus humanus.

While Arkwright and Bacot (192l) were working on the association of rickettsiae with trench fever, they noted a bacillary infection of the excreta and gut of the human louse. The causative organism, Bacillus pediculi, was found to be a parasite of the copulatory apparatus of $\underline{P}$. humanus.

*Arkwright, J. A., and Bacot, A. 1921 A bacillary infection of the copulatory apparatus of Pediculus humanus. Parasitol., 13, 25-26.

BACILLUS PESTIS (?)

Insect concerned: Lachnosterna (Phytalis) smithi. 
Bourne (1921) found that many larvae of Lachnosterna smithi were killed by an organism which resembled "Bacillus pestis." Just which species this may be is difficult to ascertain. It probably was not the true Pasteurella pestis, the cause of plague.

* Bourne, B. A. 1921 Report of the Assistant Director of Agriculture on the entomological and mycological work carried out during the season under review. Rept. Dept. Agric., 1919-20, 322-323.

\section{BACILLUS PIERIS AGILIS Paillot}

Insect concerned: The white cabbage butterfly, Pieris brassicae.

Paillot (1919) isolated Bacillus pieris fluorescens from infected caterpillars of the white cabbage butterfly. At the same time he isolated 8 other bacteria from the same source. He considered these organisms as secondary invaders in causing the death of the larvae, the parasite Apanteles glomeratus being the predisposing factor to bacterial infection. The other bacteria isolated were, Bacillus pieris liquefaciens alpha and beta, Bacillus nonliquefaciens alpha and beta, Bacillus pieris agilis, Diplococcus pieris, Diplobacillus pieris, and Bacillus proteidis.

* Paillot, A. 1919 Coccobacilles parasites des chenilles de Pieris brassicae. Compt. rend. acad. sci., 168, $476-478$.

BACILLUS PIERIS LIQUEFACIENS ALPHA Paillot Insect concerned: The white cabbage butterfly, Pieris brassicae.

Paillot (1919) isolated Bacillus pieris liquefaciens alpha and beta from diseased white cabbage butterfly larvae. (See Bacillus pieris fluorescens.)

* Paillot, A. 1919 Coccobacilles parasites des chenilles. de Pierıs brassicae. Compt. rend. acad. sci., 168, $476-478$. 
BACILLUS PIEA IS Li QUEFACIENS BETA Paillot (See Bacillus pieris liquefaciens alpha.)

BACILLUS PIERIS NON-LIQUEFACIENS ALPHA Paillot insect concerned: Tho whi e cabbage butterfly, Pieris brasaicae.

Paillot (1919) isolated Bacillus pieris non-liquefaciens alpha and beta from infected white cabbage butterfly larvae. (See Bacillus pieris fluorescens.)

* Paillot, A. 1919 Coccobacilles parasites des chenilles de Pieris brassicae. Compt. rend. acad. sci., 168, $476-478$.

BACILLUS PIERIS NON-LIQUEFACIENS BETA Paillot (See Bacillus pieris non-liquefaciens alpha.)

\section{BACILLUS PIRENEI \\ (See Bacterium pyrenei.)}

Insects concerned: Pieris spp.; the corn borer, Pyrausta nubilalis.

In laboratory and field experiments carried out near Leningrad and in Moldavia, Pospelov (1936) found that cultures of Bacilius pirenei proved to be very virulent to various lepidopterous larvae. When applied in sprays against Pieris spp. on cabbage during sunny weather, the oacilli gave 10-100 per cent mortality and remained effective for 20 days. They also killed 25 per cent of the larvae of Pyrausta nubilalis on maize.

It is quite probabie that this orgarism is the Bacterium pyrenei of Metelnikov, Ermolaev, and Skobaltzyn (1930) which they isolated trom diseased corn borers.

Metalnikov, S., Ermolaev, J., and Skobaltzyn, V. 1930

New bacteria pathogenic to the larvae of Pyrausta nubilalis Ho. Inter. Corn Borer Invest., Sci. Rpts., 3, 28-36.

Tospelov, V. P. 1936 Summary of the scientific research work of the institute of plant protection for the year

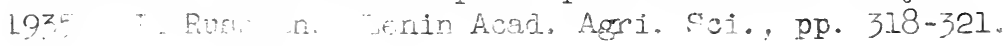




\section{BACILLUS PLUTON Whi.te}

Insect concerned: The honey bee, Apis mellifera.

Bacillus pluton was first described by White (1912) as the cause of European foulbrood and temporarily referred to as Bacillus "Y". He was unable to grow this organism on artificial media although later Wharton (1928) reported success. According to Lochhead (1928) the organism cultured by Wharton appeared to be closely related if not identical with Streptococcus apis Maassen. Burnside (1934) claims that "Bacillus alvei is capable of morphological, cultural and biological transformation and is also capable of stabilization, at least temporarily, as a sporogenic rod, an asporogenic rod resembling Bacterium eurydice, or a coccoid resembling Bacillus pluton." Burnside also suggests that Bacillus pluton, Streptococcus apis, and Bacterium eurydice are variants, or stages in the life history, of Bacillus alvei. Bergey's Manual (5th edition, page 662) apparently accepts this explanation of the relationship of these forms, although Bacterium (now Achromobacter) eurydice is given a separate description (page 517).

Burnside, C. E. 1934 Studies on the bacteria associated with European foulbrood. J. Econ. Entomol., 27, 656668.

Lochhead, A. G. 1928 The etiology of European foulbrood of bees. Science, 67, 159-160.

Wharton, D. R. A. $19 \overline{28}$ Etiology of European foul-brood of bees. Science, 66, 451-452.

* White, G. F. 1912 The cause of European foulbrood.

U. S. Dept. Agr. Bur. Ent. Circ. 157, 15 pp.

\section{BACILLUS PONCEI GIaser}

Insects concerned: Melanoplus femur-rubrum; Encoptolopus sordidus.

In 1918, Glaser made a study of the organisms distributed under the name of Coccobacillus acridiorum d'Herelle. In carrying out these studies, he obtained from Dr. Ponce of Honduras an organism which was not a "coccobacillus" at all, but an organism not heretofore described. Glaser named it Bacillus poncei. The organism was pathogenic to the above-named insects. However, in most cases, attempts to recover the bacillus from the blood, the alimentary tract, or the feces failed. 
*Glaser, R. W. 1918 A systematic study of the organisms distributed under the name of Coccobacillus acridiorum d'Herelle. Ann. Entomol. Soc. Am., 11, 19-42.

\section{BAC ILLUS POPILLIAE Dutky}

(See also Bacillus lentimorbus)

Insects concerned: The Japanese beetle, Popillia japonica; Anomala orientalis, Autoserica castanea, cyclocephala (Ochrosidia) borealis, Phyllophaga anxia, P. bipartita, P. ephilida,$\underline{\mathrm{P}}$. fusca, $\underline{\mathrm{P}}$. rugosa, Strigoderma arboricola Cotinis nitida and Macródacty]us subspinosus.

Dutky (1940) describes two spore-forming bacteria, which he names Bacillus popilliae and Bacillus lentimorbus, as the causative agents, respectively, of types $A$ and $B$ milky disease of the larvae of the Japanese beetle. In describing Bacillus popilliae, Dutky states that this organism "is a nonmotile Gram-positive rod measuring about 0.9 by 5.2 microns. The rods become swollen at sporulation, assuming first a spindle and then a pyriform shape... In the broader pole of the cell is found a refractile body, which is about half the size of the spore and possesses staining reactions similar to those of the spore." Dutky also describes the symptoms and appearance of the disease.

Subsequent to his original findings, Dutky (1941) found the following scarabaeid species to be susceptible to this disease: Anomala orientalis, Autoserica castanea, Cyclocephala (ochrosidia) borealis, Phyllophaga anxia, . bipartita, P. ephilida, $\underline{P}$. fusca, P. rugosa, Strigoderma arboricola, and Strigodermella pygmaea. On the other hand, Cotinis nitida and Macrodactylus subspinosus were not susceptible.

Dutky, S. R. 1940 Two new spore-forming bacteria causing milky diseases of Japanese beetle larvae. J. Agr.

Research, 61, 57-68.

Dutky, S. R. 1941 Susceptibility of certain scarabaeid larvae to infection by Type A milky disease. J. Econ. Entomol., 34, 215-216.

BACILLUS PRODIGIOSUS FIllgge

(See Serratia marcescens) 


\section{BACILLUS PROTEIDIS Paillot}

Insect concerned: The white cabbage butterfly, Pieris brassicae.

Paillot (1919) isolated Bacillus proteidis from larvae of diseased cabbage butterflies. From the same source, he isolated eight other bacteria. (See Bacillus pieris fluorescens. )

Paillot, A. 1919 Coccobacilles parasites des chenilles de Pieris brassicae. Compt. rend. acad. sci., 168, $476-478$.

BACILLUS PROTEUS Trevisan (See Proteus vulgaris.)

\section{BACILLUS PSEUDOXEROSIS NOgUChi}

Tick concerned: The wood tick, Dermacentor andersoni.

Noguchi (1926) isolated Bacillus pseudoxerosis from the wood tick. It was one of three microorganisms he found in this arthropod. These organisms morphologically resembled the rickettsia causing spotted fever. However, they were found to be non-pathogenic for laboratory animals and immunologically they were not related to the spotted fever rickettsia.

Bacillus pseudoxerosis is a non-motile, slender, pleomorphic bacillus. It is apparently non-spore-forming, hence the generic name Bacillus is not acceptable according to rules of nomenclature.

*Noguchi, H. 1926 Cultivation of rickettsia-like microorganisms from the Rocky Mountain Spotted Fever tick,

Dermacentor andersoni. J. Expt1. Med., 43, 515-532.

\section{BACILLUS PUNCTATUS}

Insect concerned: Locusta migratoria.

In experimental infection of Locusta migratoria using a mixture of Bacillus fluorescens liquefaciens, Bacillus punctatus, and Coccobacillus acridiorum, Shul'gina and Kalinicker (1927) found the mixture gave a low mortality. 
Shul'gina, O. G. and Kalinicker, P. A. 1927 Experimental infection of Locusta migratoria with bacterial disease. Rep. Bur. Appl. Ent. 3, No. 1, 99-104. Leningrad. (Summary in English).

\section{BACILLUS PYOCYANEUS Gessard}

Insects concerned: Schistocerca gregaria; the bee moth, Galleria mellonella; the silkworm, Bombyx mori; the house fly, Musca domestica; and Stomoxys calcitrans.

Metalnikov (1920) in a serios of experiments to determine the immunity of the bee moth against certain classes of microorganisms, found the bee moth susceptible to small doses of Bacillus pyocyaneus. Couvreur and Chabovitch (1921) found that the blood and digestive juices of the larvae and pupae of Bombyx mori destroyed the organism. Sawamura (1906) lists this organism as being artificially pathogenic to the silkworm.

Duncan (1926) isolated it from the gut contents of one lot of Stomoxys calcitrans.

During an epidemic which occurred in the laboratory rearing of Schistocerca gregaria, Lepesme (1937) found Bacillus pyocyaneus present in the body fluid. Experimentally, it caused death in one to two days. He (1938) also found it to be a secondary invader to the infestation of the fungus, Aspergillus flavus, in this insect.

Bacot (1911) found that the pupae and imagines of Musca domestica bred from larvae infected with Bacillus pyocyaneus remain infected with the bacillus.

Pseudomonas aeruginosa is the accepted name for Bacillus pyocyaneus. (see Bergey's Manual, 5th ed., p. 126.)

Bacot, A. W. 1911 The persistence of Bacillus pyocyanous in pupae and imagines of Musca domestica raised from larvae experimentally infected with the bacillus. Parasitol. , 4, 68-74.

Couvreur, $\overline{\mathrm{E}}$. and Chahovitch, X. 1921 Com. rend. Acad.

Sci., Paris, 172, 711-713.

Duncan, J. T. 1926 On a bactericidal principle present

in the alimentary canal of insects and arachnids. Parasitol., 18, 238-252.

Lepesme, P. 1937 Action de Bacillus prodigiosus et

Bacillus pyocyaneus sur le criquet pelerin (Schistocerca gregaria, Forsk.). Compt. rend. soc. biol., 125, 492494.

Lepesme, P. 1938 Recherches sur une aspergillose des acridiens. Bull. Soc. Hist. Nat. Afr., N., 29, 372-384. 
Metalnikov, S. 1920 Immunité de la chenille contre divers microbes. Compt. rend. soc. biol., 83, 119-121.

Sawamura, S. 1906 Note on bacteria pathogenic to silkworm. Tokyo Imp. Univ. Coll. Agr. Bull., 7, 105.

\section{BACILLUS PYRAMEIS I Paillot}

Insect concermed: Pyrameis cardui.

Paillot (1913) isolated two different "coccobacilli" from the tissues and blood of caterpillars of Pyrameis cardui. He named these, Bacillus pyrameis I and Bacillus pyrameis II.

* Paillot, A. 1913 Coccobacilles parasites d'insectes. Compt. rend. acad. sci., 157, 608-611.

\section{BACILLUS PYRAMEIS II Paillot \\ (See Bacillus pyrameis I)}

\section{BACILLUS RICKETTSIFORMIS NOgUChI}

Tick concerned: The wood tick, Dermacentor andersoni.

Bacillus rickettsiformis was isolated by Noguchi (1926) from the wood tick. This bacillus and two other microorganisms which Noguchi isolated from the same source, morphologically resembled the rickettsia which causes spotted fever. Bacillus rickettsiformis was more frequently isolated than the other two. They were found to be nonpathogenic for laboratory animals and immonologically not related to the spotted ferer rickettsia.

Bacillus rickettsiformis is moderately motile, and lanceolate, fusiform, or rod-shaped. In old cultures there is considerable pleomorphism. Since the organism is a Gram negative, apparently non-spore-forming rod, the generic name Bacillus is not correct according to accepted nomenclature.

* Noguchi, H. 1926 Cultivation of rickettsia-like micro. organisms from the Rocky Mountain spotted fever tick, Dermacentor andersoni. J. Exptl. Med., 43, 515-532.

\section{BACILLUS ROTANS Roberts}

Insect concerned: Termites in Texas. (Identity not stated in original paper.) 
During an investigation of the intestinal flora of termites of central Texas, Roberts (1935) isolated an organism which seemed to be uniformly present in the ter. mite intestine. He named the organism Bacillus rotans, because of the rotary motility of young colonies.

A complete description of this organism may be found in Bergey's Manual, 5th edition, p. 696.

*Roberts, J. L. 1935 A new species of the genus Bacillus exhibiting mobile colonies on the surface of nutrient agar. J. Bact., 29, 229-238.

\section{BACILLUS RUBEFACIENS Zimmermann}

Insect concerned: The silkworm, Bombyx mori.

This bacterium was Iisted by Sawamura (1906) as pathogenic to silkworm larrae when experimentally infected.

Sawamura, S. 1906 Note on bacteria pathogenic to silkworm. Tokyo Imp. Univ. Coll. Agr. Bull., 1, 105.

\section{BACILLUS SALUTARIUS Metchnikoff}

Insect concerned: Anisoplia austriaci.

Paillot (1933) refers to this bacillus as having been found by Metchnikoff in 1879 while studying the "Green Muscardine" of Anisoplia austriaca. Metchnikoff found this organism in many of the dying larvae.

*Metchnikoff, E. 1879 Maladies des hannetons du ble (Anisoplia austriaca). Odessa [In Russian]. Paillot, A. 1933 L'infection chez les insectes, 535 pp. Imprimerie de Trevoux, Paris. (See page 123.)

\section{BAC ILLUS SEPTICAEMIAE LOPHYRI Shiperovich}

Insect concerned: The sawfly, Diprion sertifer.

In 1925, Shiperovich observed a bacterial disease among the larvae of sawflies due to an organism which he named Bacillus septicaemiae lophyri. Schwerdtfeger (1936) says that it probably caused mass mortality among the larvae of sawflies in nature. 
Schwerdtfeger, F. 1936 Zur Kenntnis der roten Kiefernbuschhornblattwespe, Diprion sertifer Geoffr. (Lophyrus rufus Panz.). Z. pfl. Krankh., 46, 513-534. (See also Rev. Appl, Entomol. A., 25, 54.)

* Shiperovich, V. va. 1925 A sawfly injurious to the pine and its control. [In Russian.] Protect. Plants Ukraine, 1925, 41-46. (See also Rev. Appl. Entomol., A, 14, 209.)

\section{BACILLUS SEPTICUS INSECTORUM Krasilstschik}

Insect concerned: The cockchafer, Melolontha melolontha.

In 1893, Krassilstschik isolated this organism from cockchafers and found it to be the cause of a septicemia among the larvae. The organism seems to gain entrance into the larvae by way of the skin for Krassilstschik (1916)' states: "The larvae are not cannibals in the sense that they devour each other, but they often attack and wound one another and these wounds, however slight, often prove fatal, as they provide means of entry of noxious bacteria."

Northrup (1914) found a gas-producing bacillus associated with Micrococcus nigrofaciens which she thought might be $\underline{B}$. septicus insectorum.

*Krassilstschik, I. M. 1893 La Graphitose et la

Septicemie chez les Insectes. Memoires de la Société Zoclog. de France, 6, 245-285.

Krassilstschik, I. M. 1916 Report on the work of the

Bio-Entomological Station for Bessarabia in 1914-1915. Kishinew, 1916, $96 \mathrm{pp}$.

Northrup, Zoe 1914 A bacterial disease of June beetle larvae, Lachnosterna sp., Mich. Agri. Coll. Expt. Station Tech. Bull. No. 18, $36 \mathrm{pp}$.

\section{BACILLUS SIMILIS}

Insects concerned: The nun moth, Lymantria monachae; the white cabbage butterfly, Pieris brassicae; Porthesia auriflua; and Vanessa urticae.

This spore-forming bacillus was found by Eckstein (1894) to be pathogenic for the larvae of the above-listed insects which had been experimentally infected. Eckstein asserts that this organism is similar to the well-known Bacillus megatherium. 
Wckin, K. 1894 Untersuchungen Uber die in Raupen vorkommenden Bakterien. Z. f. Forst- und Jagdwesen, 26, $3-20,228-241,285-298,413-424$.

\section{BACILLUS SOLANACEARUM Smith (See Phytomonas Bolanacearum.)}

\section{BACILLUS SOTTO Ischivata}

Insects concerned: The silkworm, Bombyx mori; the corn borer, Pyrausta nubilalis.

Bacillus sotto and Bacterium sotto are probably the same organism. Paillot (1928) refers to it as the "Bacillus sotto of Ischivata" while Metalnikov and Chorine (1928) refer to it as "Ischivata's Bacterium sotto." The organism is a spore-former and rightly should be called Bacillus.

According to Aoki and Chigasaki (1915), Ischivata stated that it was the cause of a severe epidemic of flacherie in 1902 among silkworms of Japan and they also found it to be pathogenic to the silkworm. However, Paillot (1928) states that Bacillus sotto has been "erroneously considered the cause of flacherie" by the Japanese authors.

Paillot (1928) carried out experiments using Bacillus sotto against larvae of Pyrausta nubilalis. He found the organism was not very effective against the insect, as only three out of the ten corn borers infected showed signs of disease at the end of three days, while the others were still healthy. Metalnikov and Choriile (1928) were not able to infect the corn borer by mouth with Bacillus sotto

Aoki, K. and Chigasaki, I. 1915 Über das Toxin von sog. Sotto Bacillen. Mitteil der Med. Fakult. der Kaiser Univer. zu. Tokyo. Bd. 14, heft 1, 1915.

Metalnikov, S. and Chorine, V. 1928 The infectious diseases of Pyrausta nubilalis Ho. Inter. Corn Borer Invest., Sc1. Repts., 1, 41-69.

Paillot, A. 1928 On the natural equilibrium of Pyrausta nubilalis $\mathrm{Hb}$. Inter. Corn Borer Invest., Sci. Rpts., I, 77-106. 


\section{BACILLUS SPERMATOZOIDES}

Insect concerned: Hyponomenta evonymella.

While studying the bacteria associated with the nun moth, Lymantria monacha, Eckstein (1894) cultivated this bacillus from dead Hyponomenta evonymella.

Eckstein, K. 1894 Untersuchungen tber die in Raupen vorkomenden Bakterien. Z. f. Forst- und Jagdwesen, 26, 3-20, 228-241, 285-298, 413-424.

\section{BACILLUS SPHINGIDIS White (See also Bacilius noctuarum White.)}

Insects concerned: The tomato-worm, Protoparce (Phlegothontius) quinquemaculata; the tobacco-worm, Protoparce (Phlegothontius) sexta; the catalpa moth caterpillar, Ceratomia catalpae; and the silkworm, Bombyx mori. (See also those insects listed under Bacillus noctuarum.)

As indicated on page 605 of the 5th edition of Bergey's Manual, Bacillus sphingidis is very similar, if not identical, to Bacillus noctuarum. These two organisms seem to have enough characteristics in common to be considered the same species. Bacillus sphingidis has also been known by the names: Escherichia sphingidis (Bergey's Manual, $3 \alpha$ ed., 1930, p. 327) and Proteus sphingidis (Bergey's Manual, 4 th ed., 1934, p. 366).

Bacillus sphtngidis is a Gram-negative, non-spore-forming, short rod. Inasmuch as the genus Bacillus is reserved for spore-forming rods only, it can be seen that Bacillus sphingidis does not bear the proper generic name.

According to White (1923) caterpillars, feeding on tobacco and tomato leave's, have been found to develop disease caused by Paclllus sphtngidis. This bacterium is also pathogenic for the larvae of Ceratomia catalpae and the silkworm, Bombyx mori.

*White, G. F. 1923 Hornworm septicemia. J. Agric. Research, 26, $477-486$.

BACILLUS SUBGASTRICUS

Irsect concerned: The honsy bee, Apis mellifera. 
White (1906) isolated Bacillus subgastricus from the intestine of a healthy honey bee. He gives a complete description of it. This organism may be a variant of Baclilus gastricus Ford (see Bergey's Manual, 5th ed., p. 603) though the two differ in oxygen requirements, indol production, and nitrate reduction.

*White, G. F. 1906 The bacteria of the apiary with speclal reference to bee diseases. U. S. Dept. Agr., Bur. Entomol., Tech. Bull. No. 15, $50 \mathrm{pp}$.

\section{BACILLUS SUBTILIS Cohn}

Insects and ticks: The wood-digesting roach, Crytocercus punctulatus; the bee moth, Galleria mellonella; the cecropia moth, Platysamia cecropia; Ceratomia catalpae; Sinea diadema; Lygus pratensis; Conocephalus fasciatus, var. fasciatus; and a species each in the families Chrysomilidae and Curculionidae; Grylloblatta campodeiformis campodeiformis; Stomoxys calcitrans; Cimex lectularius; Rhodnius prolixus; and the ticks Argas persicus and Ormithodoros moubata.

Bacillus subtilus, the common "hay bacillus," is widely distributed in nature in the air, soil, and decomposing organic materials. For this reason it is perhaps not surprising that this bacillus should be found associated with insects. It seems very probable that some of the early named organisms described as being associated with insects may have been Bacillus subtilus or closely related sporeformers. (See Bergey's Manual, 5th ed., p. 646, for a complete description of Bacillus subtilis.

Metalnikov (1920) found Galleria mellonella to be very susceptible to infection with Bacillus subtilis, the insects dying from extremely small doses. Hatcher (1939) found Bacillus subtilus in the colon of the roach, Cryptocercus punctulatus. Steinhaus (1941) found bacilli of this group in the alimentary canals of normal larva of Platysamia cecropia, Ceratomia catalpae, in normal adults of Lyous pratensis, conocephalus fasciatus, and in normal nymphs of Sinea diadema. Burroughs (1941) found several straina of Bacillus subtilis in the alimentary tract of a grylloblattid.

Hindle and Duncan (1925) found Bacillus subtilis to survive "in the stomach of Argas persicus for a time, and is passed in the faeces, thus behaving similarly to $\underline{B}$. anthracis." Duncan (1926) found the gut-contents of Argas persicus, as well as Ornithodoros moubata, Stomoxys calcitrans, C1mex lectularius, and Rhodnius prolixus, to be bactericidal to B. subtilis. 
Burroughs, A. L. 1941 Bacterial flora of the alimentary tract of Grylloblatta campodeiformis campodeiformis Walker. Montana State College Master's Thesis, $47 \mathrm{pp}$. Duncan, J. T. 1926 On a bactericidal principle present in the alimentary canal of insects and arachnids. Parasitol., 18, 238-252.

Hatcher, E. $1 \overline{939}$ The consortes of certain North Carolina blattids. J. Elisha Mitchell Sci. Soc., 55, 329-334. Hindle, E., and Duncan, J. T. 1925 The viability of bacteria in Argas persicus. Parasitol., 17, 434-446. Metalnikov, S. 1920 Compt, rend. sci. biol., 83, 119. Steinhaus, E. A. 1941 A study of the bacterta associated with thirty species of insects. J. Bact., 42, 757-790.

\section{BACILLUS TENAX}

Insect concerned: The nun inoth, Lymantria monacha.

Eckstein (1894) isolated this spore-forming bacillus from the larva of the nun moth.

Eckstein, K. 1894 Untersuchungen ther die in Raupen Vorkomenden Bakterien. Z. f. Forst- und Jagdwesen, 26, 3-20, 228-241, 285-298, 413-424.

\section{BACILLUS THUPINGIENSIS Berl.iner}

Insects concerned: The merl moth; Ephestia klhnielle; the corn borer, Pyrausta nub1lalis; the cabbage butterfly, Pieris brasgicas; Echnocerus cornv.tus; Por thetria dispar; Vanessa urticae.

In 1915, Berliner isolated Bacillus thuringiensis from the larvae of the meal moth, Ephestia klhniella. Experiments showed that the infection occurred through ingestion and developed in the intestinal tract. Mattes (1927) found that the larra could be earily infected by mouth with Bacillus thuringiensig, the spores multiplying internally and causing death. Sheperd (1924) states that the organism has been used for control of Echnocerus cormutus. White (1927) reported he had encountered the infection among Ephestia kuhniella larvae in the Washington Laboratory.

Bacillus thuringiensis ranks among the most pathogenic of bacteria to the corn borer. Infection of corn borers through the mouth gives almost 100 per cent fatality. Hugz (1927) was the first to infect com borers. Under 
experimental conditions, he was able to kill borers in one and one-half days by infection with the bacillus and its spores. The organism has been used quite effectively in combating the corn borer. (Husz, 1929, 1930).

In some literature, (Chorine, 1929; Metalnikov and Chorine 1929; Metalnikor and Chorine 1929a; Ellinger and Chorine 1930a) Bacillus thuringiensis has been referred to as Bacterium thuringiensis. However, Ellinger and Chorine (1930b) state "two strains of bacteria that were isolated from Ephestia klhniella Zell. by Metalnikov and Chorine and utilized by them against Pyrausta nubilalis $\mathrm{Hb}$. and were referred to as Bacterium thuringlensis numbers 1 and 2. . are identical with Bacillus thuringiensis isolated by Berliner and subsequently studied by Husz." Berliner named the organism correctly since it is a sporeformer.

Chorine (1929) has given a complete description of this organism.

*Berliner, t. 1915 uber die Schlaffrucht der Mehlmottenraupe (Ephostia klthiella, Zell) und ehren Erreger, Bacillus thuringiensis, n. sp. Zeitschr. 1 . Angew. Entom., Berlin, i. No. 1, Apri1, 29-56.

Chorine, V. 1929 New bacteria pathogenic to the larvae of Pyrausta nubilalis $\mathrm{Hb}$. Internat. Corn Borer Invest., Sci. Repts., 2, 39-53.

Ellinger, T. and Chorine, V. 1930 a Note on the bacteria isolated from Eohestia kuhniella Zell. Internat. Corn Borer Invest. Sci. Repts., 3, 37-38.

Ellinger, T. and Chorine, $V$. 1930b Sur les microbes d'I Phestia kthniella Zell. Compt. rend. soc. biol., $103,401-402$.

Husz, B. 1927 Bacillus thuringiensis Berl., A bacterium pathogenic to corn borer larrae. Internat. Corn Borer Invest., Sci. Repts., 1, 191-193.

Husz, B. 1929 The ure of Bacillus thuringiensis in the

fight against the corn borer. Internat. Corn Borer

Invest., Sc1. Repts., 2, 99-110.

Husz, B. 1930 Field experiments on the application of

Bacillus thuringiensis againat the corn borer. Internat.

Corn Borer Invest., Sc1. Repts., 3, 91-98.

Mattes, 0. 1927 Parasitsire Krankheiten der Mehlmottenlarven und Versuche uber ihre Verwendbarkeit als

biologische Bekdmplungsmittel. Sitz Ber. Ges. Beflyderung Naturw. Marburg, 62, 381-417.

Metalnikov, S. and Chorine, V. 1929 Experiments on the use of bacteria to destroy the corn borer. Internat. Corn Borer Invest.: Sci. Repts., 2, 54-59. 
Irlkov, S. and Chorine, V. I929a on the infection of the Gyps $;$ moth and certain other insects with Bacterium thuringiensis. Internat. Corn Borer Invest., Sci. Repts., 2, 60-61.

Sheperd, D. 1924 Life history and biology of Echocerus cornutus (Fab.). J. Econ. Entomol., 17, 572-577. White, G. F. 1927 A protozoan and a bacterial disease of Eohestia klhniella Zell. Proc. Bntomol. Soc. Wash., 29, $147-148$.

\section{BACILLUS IINGENS}

Insectis concerned: Orgyia pudibunda; the nun moth, Iytrantria monacha.

Eckstsin (1894) fow Bacillus tingens in the dead larvae of Orgyia pudibunda, and was experimentally infective for the man moth.

Fckstein, Ko 1894 Unterguchungen uber die in Raupen vorkomenden Bakterier. Z. f. Forst- und Jagdwesen, 26, 3-20, 228-241, 285-298, 413-424.

BACILLUS TRACHEIPHILUS

(See Erwinia tracheiphila.)

BACILLUS TRACHEITIS SIVE GRAPHIJOS IS KraSgilstschik

Insect concerned: The cockchafer, Melolontha melolontha.

Krassilstschik (1893) working on the diseases of the larvae of the cockchafer, isolated a spore-forming motile bacillus to which he gave the cumbersome name Bacillus tracheitis sive graphitosis. The disease, "graphytose", was characterized by a lead color of the body at the time of the insect's death.

* Krassilstschik, J. M. 1893 La graphitose et la septicéme chez les insectes. Memoires de la Société Zoolog. de France, 6, 245-285.

BAC ILLUS VERRUCOSUS Lehmann and Sussman (See Bacillus foetidus.) 


\section{BACILLUS VIOLACEUS \\ (See Chromobacterium violaceum.)}

$\frac{\text { BACILLUS }}{\text { (See Bacillus mesentericus.) }}$

\section{BACILLUS VIRIDANS}

Insect concerned: The silkworm, Bombyx mori.

This organism was listed by Sawamura (1906) as pathogenic to silkworm larvae when artificially infected.

Sawamura, S. 1906 Note on bacteria pathogenic to silkworm. Tokyo Imp. Univ. Coll. Agr. Bull., 1, 105.

\section{BAC ILLUS X White \\ (See Bacillus larvae.) \\ BACILLUS Y White \\ (See Bacilius pluton.)}

Insects concerned: The honey bee, Apis mellifera; and the house fly, Musca domestica.

During his studies on the bacterial diseases of bees, White (1912) temporarily referred to Bacillus pluton as Bacillus "Y." Tebbutt. (1913) also refers to a "Bac. Y" in a paper on the bacteria of the house fly.

Tebbutt, H. 1913 On the influence of the metamorphosis

of Musca domestica upon bacteria administered in the

larval stage. J. Hyg., 12, 516-526.

White, G. F. 1912 The cause of European foulbrood. U. S.

Dept. Agr. Bur. Ent. Circ. 157, 15 pp.

Genus: Clostridium

\section{CLOSTRIDIUM BOTULINUM TYPE C Bengtson}

Insects concerned: The blue-bottle fly, Lucilia caesar; the water beetle, Enochrus hamiltoni. 
Bengtson (1922) 1solated an anaerobic spore-forming organism from the larvae of Lucilia caesar which caused limberneck in chickens. She did not give a name to the organism but in Bergey's Manual (3d ed., 1930) the organism is referred to as Clostridium Iuciliae Bengtson. However, in the 5th edition (1939, p. 755), the organism is called Clostridium botulinum Type C. Bengtson.

Gunderson (1935) reported finding Clostridium botulinum type $\mathrm{C}$ in both larvae and cocoons of the water-beetle, Enochmus hamiltoni, and attributed an epizootic amons sandpipers to be due to the presence of this organism in the larvae, the sandpiper feeding upon them.

*Bengtson, Ida. 1922 Toxin producing anaerobe. U. S.

Pub. Health Rep., 37, 164-170 and 2252-2253. Gunderson, M. F. 1935 Insects as carriers of Clostridium botulinum. J. Bact., 30, 333.

CLOSTRIDIUM LUCILIAE Bengtgon (See Clostridium botulinum Type C.)

\section{CLOSTRIDIUM TETANI (Nicolaier) Holland}

Insect concerned: The bee moth, Galleria mellonella.

Metalnikov (1920) made a number of experiments to determine the immunity of the larvae of the bee moth against various classes of microorganisms. He found the larvae to be completely immune to infection with clostridium tetani.

Metalnikov, S. 1920 Immunité de la chenille contre divers microbes. Compt. rend. soc. biol., 83, 119-121.

\section{CLOSTRIDIUM WERNERI Bergey et al.}

Insect concerned: The rose-leaf beetle, Potosia cuprea.

Werner (1926) isolated a bacillus from the digestive tract of the larva of Potosia cuprea which fermented cellulose. He called the organism Bacillus cellulosam fermentans and it was designated as such in the 4 th edition of Bergey's Manual. However in the 5th edition, 1939 ( 785), the name was changed to Clostridium werneri.

Werner was unable to decide whether the larva uses the products of fermentation of cellulose directly for meta- 
Olic purposes, or whether the fermentation only destroys the cell walls and mokes the contents of the cell available as food for the larva.

*Werner, E. 1926 Die Ernahrung der Larve von Potosia cuprea, Farb. Ein Beitrag zur Problem der Cellulosenverdauung bei Insektenlarven. Zeitschr. Morph. Okol. Tiere, 6, 150-206.

Werner, E. 1926 Bacillus cellulosam fermentans. Cent. f. Bakt., II abt., 67, 297 .

Family: BACTER IACEAE

Genus: Achromobacter

ACHROMOBACTER DELICATULUM (Jordan) Bergey et al. (See also Achromobacter hyalinum.)

Insect concerned: The Colorado potato beetle, Leptinotarsa decemlineata.

Steinhaus (1941) isolated this bacterium from the alimentary tract of the Colorado potato beetle. See Bergey's Manual (5th ed., p. 505) for a complete description.

Steinhaus, E. A. 1941 A study of the bacteria associated with thirty species of insects. J. Bact., 42, 757-790.

\section{ACHBOMOBACTER EURYDICE (White) Bergey et al. (See also Bacillus alvei and Bacillus pluton.)}

Insect concerned: The honey bee, Apis mellifera.

White (1912) named this orsanism Bacterium eurydice. Bergey et al. (see Bergey's Manual, 2d ed., 1935, p. 170; sec also 5th ed., 1939, p. 517), renamed it Achromobacter eurydice.

White was unable to produce European foulbrood in bees with Bacterium eurydice, although it is apparently a secondary invader in the disease. Burnside, (1934) found that Bacillus alvei, the recognized causative agent of European foulbrood, is capable of morphclogic, cultural, and biologic transformation, and he further states that Bacillue alvei"ls also capable of stabilization, at least temporarily, as a sporogenic rod, an asporogenic rod resembling Bacterium eurydice, or a. coccoid resembling 
Bacillus pluton." Burnside suggests that Bacillus pluton, Streptococcus apis, and Achromobacter (Bacterium) eurydice are varlants, or stages in the life history, of Bacillus alvei. Bergey's Manual (5th ed., 1936, page 517), gives a separate description for Achromobacter eurydice.

Burnside, C. E. 1934 Studies on the bacteria associated with European foulbrood. J. Econ. Entomol., 27, 656-668. *White, G. F. 1912 The cause of European foulbrood.

U. S. Dept. Agr. Bur. Ent. Cir. 157, 15 pp.

\section{ACHROMOBACTER HYALINUM Bergey et al.}

Insect concerned: The American cockroach, Periplaneta americana.

Hatcher (1939) states that "Acromobacter hyalinum (Jordon)" was one of the species of bacteria she isolated from the fecal matter of Periplaneta. The generic name of this organism was probably misspelled and no doubt was meant to be Achromobacter. According to the 5th edition of Bergey's Manual, 1939, page 505, Bacillus hyalinus Jordon (Achromobacter hyalinum Bergey et al. ) is possibly a synonym for Achromobacter delicatulum (Jordon) Bergey et al. In the first edition of Bergey's Manual, 1923, page 138, the name Bacillus hyalinus Jordon, the chief habitat of which is water, was renamed Achromobacter hyalinum by Bergey et al. Apparently it is this organism which Hatcher found in the roach, Periplaneta americana.

Hatcher, E. 1939 The consortes of certain North Carolina blattids. J. Elisha Mitchell Sci. Soc., 55, 329-334.

ACHROMOBACTER LARVAE (Stutzer and Wsorow) Bergey et al.

Insect concerned: Euxoa segetum.

This organism, isolated by Stutzer and Wsorow (1927) from the intestinal tract of normal caterpillars of Euxoa segetum, was named by its discoverers Entero-bacillus larvae, and was so designated in the 3 d edition of Bergey's Manual, 1930, page 227. However, in the 5th edition of Bergey's Manual, 1939, page 517, it is described under the name Achromobacter larvae. Besides this species, several other species of bacteria were found in the intestineil tracts of the normal caterpillars. 
*Stutzer, M. J.", and Wsorow. W. J. 1927 Veber Infectionen der Raupen der Wintersaateule (Euxoa segetum Schiff). Cent. T. Bakt. v. Parasit., 11, 113-129.

\section{ACHROMOBACTER SUPERFICIALE (JOrdon) Bergey et al.}

Insect concerned: Urographus fasciata.

In the larvae of Urographus faciata, Steinhaus (1941) found a bacterium which corresponded fairly well to the incomplete description given in Bergey's Manual (1939, 5th ed., page 511) for Achromobacter superficiale. However, the growth on agar of the organism isolated was more abundant than that of Achromobacter superficiale, which is described as being "limited."

Steinhaus, E. A. 1941 A study of the bacteria associated with thirty species of insects. J. Bact., 42, 757-790.

Genus: Bacterium

BACTERIUM SP. De Bach and McOmie

Insect concerned: The termite, Zootermopsis augusticollis.

DeBach and Mcomie (1939, found their laboratory stock of the termite, Zootermopsis augusticollis, to be afflicted with two bacterial diseases. One of these diseases was caused by Serratia marcescens (which see), while the other was caused by a bacterium which they designated as Bacterium sp. The disease caused by the latter organism was less common than that caused by Serratia marcescens.

DeBach and McOmie found Bacterium sp. to be similar to Bacterium neopolitanum according to the classification system of Kluyver and van Niel (1936).

* De Bach, P. H., and McOmie, W. A. 1939 New diseases of termites caused by bacteria. Ann. Entomol Soc. Amer., 22, $137-146$.

Kluyver, A. J., and van Niel, C. B. 1936 Prospects for a rational system of bacterial classification. Cent. T. Bakt., Abt. II., 24, 369. 


\section{BACTERIUM ACIDIFORMANS Sternberg}

Insect concerned: The honey bee, Apis mellifera.

White (1906) isolated Bacterium acidiformans from the scrapings of propalis and wax from honey frames and hives of healthy colonies of honey bees. He has given a complete description of the organism.

White, G. F. 1906 The bacteria of the apiary with special reference to bee diseases. U. S. Dept. Agr., Bur. Entomol., Bull. \#14, 50 pp.

\section{BACTERIUM BOMBYCIS (See Bacillus $\overline{\text { bombycis. }) ~}$}

BACTERIUM BOMBYCIVORUM (See Aerobacter bombycis.)

\section{BACTERIUM CANADENSIS ChOrine}

Insects concerned: The corn borer, Pyrausta nubilalis; Galleria mellonella; Ephestia Kllhnielia.

Chorine (1929) isolated this organism from diseased Canadian corn borer larvae and found it to be very pathogenic to the larvae of the above-listed insects, all being easily infected by mouth. In its genaral characteristics, it resembles Bacillus megatherium and Bacillus thuringiensis. A complete description of the organism has been given by Chorine (1929).

Since the organism is a spore-former, it would seem that the generic name Bacillus is preferable to that of Bacterium.

* Chorine, V. 1929 New bacteria pathogenic to the larvae of Pyrausta nubilalis Hb. Internat. Corn Bor ər Sci. Invest., , $39-53$.

BACTERIUM CAZAUBON Metalnikov et al.

Insects concerned: The corn-borer, Pyrausta nubilalis; Porthetria dispar; Vanessa urticae; Ephestia kthniella; Stilpnotia salicis; Aporia crataegi. 
Metalnikov (1930) states that Bacterium cazaubon is pathogenic for all of the above insects, being one of the most virulent bacteria known for the corn borer, killing the larvae in 10 to 15 hours after infection through the mouth. The infected larvae usually become black in color. It is quite likely that Bacterium cazaubon, Bacterium cazaubon No. I, and Bacterium cazaubon No. II (Metalnikov,

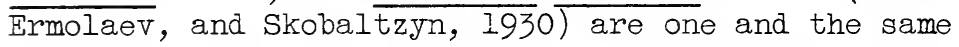
organism. Since the organism or organisms are spore formers, it seems that the preferable generic name would be Bacillus.

Complete descriptions of Bacterium cazaubon No. I and Bacterium cazaubon No. II have been given by Metalnikov, Ermolaev, and Skobaltzyn (1930).

Metalnikov, S. 1930 Utilisation des microbes dans la lutte contre Lymantria et autres insectes nuisbles.

Compt. rend. soc. biol., 105, 535-537.

*Metalnikov, S., Ermolaev, J., and Skobaltzyn, V. 1930

New bacteria yathogenic to the larvae of Pyrausta nubilalis $\mathrm{Hb}$. , Internat. Corn Borer Invest., Sci. Repts., $\underline{\overline{3}}, 28-36$. $\frac{\text { BACTERIUM }}{\text { (See Bacterium cazaubon.) }}$ 슬

BACTERIUM CAZAUBON No. 11 Metalnikov et al. (See Bacterium cazaubon.)

\section{BACTERIUM CELLULOSUM}

Insect concerned: Cetonia floricola.

According to Jepson (1937), Werner thinks that Bacterium cellulosum plays an essential role in the nutrition of the inquiline larva of Cetonia floricola.

Jepson, W. F. 1937 Observations on the morphology and bionomies of Serica brunnea L. with notes on allied chafer pests. Part $\bar{I}$. The morphology of the larva of Serica brunnea L. Bull. Entomol. Research, 28, 149165. 
Chorine (1929) isolated this organism from Canadian larvae of Pyrausta nubilalis. The organism, in its biological characteristics, resembles Bacterium ontarioni, though not in its morphological characters and in the development of the colonies. The organism is a sporeformer, so it should have been placed under the genus Bacillus.

*Chorine, V. 1929 New bacteria pathogenic to the larvae of Pyrausta nubilalis Hb. Internat. Corn Borer Invest., Sci. Repts., 2., 39-53.

\section{BACTERIUM COL! Lehmann and Neumann \\ (See Escherichia coli.)}

\section{BACTERIUM COLI APIUM SerbinOW}

Insect concerned: The honey bee, Apis mellifera.

Serbinow (1915.) states that Bacterium coli apium and Proteus alveicola were the cause of an infectious diarrhoea among honey bees during the spring of the year. The organisms were found to be infectious to mice by peritoneal inoculation.

Serbinow, I. L. 1915 J. Microbial. Petrograd. 2, 19.

\section{BACTERIUM CONJUNCTIVITIDIS (Kruse) Migula}

Insect concerned: The house fly, Musca domestica.

According to Patton (1931), Wollman, working in Tunis, placed houseflies in tubes containing cultures of Baclllus aegyptius (Bacterium conjunctivitidis) and the MoraxAxenfeld bacillus (see Hemophilus duplex) of subacute conjunctivitis, and observed that while they became infective immediately afterwards, they were not infective after an interval of three and a half hours.

Patton, W. S. 1931 Insects, ticks, mites, and venomous animals of medical and veterinary importance. Part II. Public Health. 740 pp. H. R. Grubb, Itd., Croydon. 
Insect concerned: The honey bee, Apis mellifera.

White (1906) isolated Bacterium cyaneus from pollen and the bodies of healthy honey bees. He has given a complete description of the organism.

White, G. F. 1906 The bacteria of the apiary with special reference to bee diseases. U. S. Dept. Agr., Bur. Entomol., Bull. \#14, $50 \mathrm{pp}$.

\section{BACTERIUM D White}

Insect concerned: The honey bee, Apis mellifera.

White (1906) frequently found Bacterium $\underline{D}$ present in the integtines of normal honey bees. Since the body temperature of the honey bee and that of warm-blooded animals is about the same, he found that the bacterial flora of the honey bee intestine was very similar to man and animals.

He has given a complete description of the organism which is an anaerobe.

White, G. F. 1906 The bacteria of the apiary with special reference to bee diseases. U. S. Dept. Agr., Birreau Entomol., Tech. Bull., No. 15, 50 pp.

BACTERIUM DELENDAE-MUSCAE Roubaud and Descazeaux

Insects concerned: The stable fly, Stomoxys calcitrans; the house fly, Musca domestica; blow flies and flesh flies.

In 1923, Roubaud and Descazeaux discovered a bacterial disease of fly larvae caused by Bacterium delendae-muscae. They state that it is the first microorganism described in literature that causes a specific bacterial infection of house and other flies. The disease is primarily a larval infection, the larvae becoming infected by ingesting the bacteria with their food and die in from 2 to 30 days. Flesh flies die at the commencement of the pupae stage, house flies at the end of that stage and Stomoxys after emergence.

*Roubaud, E. and Descazeaux 1923 Sur un agent bacterien pathogene pour les mouches communes: Bacterium delendaemuscae n. sp. Compt. rend. hebdom. acad. sci., 177, 716- 


\section{BACTERIUM ELBVIBRIONEN}

Insect concerned: The meal worm, Tenebrio molitor.

Bacterium elbvibrionen, a phosphorescent bacterium, was found to be pathogenic for the mealworm by Pfeiffer and Stammer (1930).

Pfeiffer, H. and Stammer, H. J. 1930 Pathogenes Leuchten bei Insekteri., Z. f. Morph. und Okal der Tiere, 20, $136-171$.

BACTERIUM $\frac{\text { EPHESTIAE }}{\text { See Bacillus }} \frac{1}{\text { thuringiensis. })}$

Insects concerned: The corn borer, Pyrausta nubilalis; flour moth, Ephestia klhniella; Pectinophora gossyciella.

This organism, along with Bacterium ephestiae №. 2, was isolated by Metalnikov and Chorine (Chorine, 1929) from Ephestia klihniella and used to combat corn borers. These organisms are identical with Bacillus thuringiensis as shown by Ellinger and Chorine (1930).

(See Bacillus thuringiensis for a more complete discussion.)

*Chorine, V. 1929 Nouveaux microbes pathogenes pour les chenills de la pyrale du mais Pyrausta nubilalis, $\mathrm{Hb}$. An. Inst. Pasteur, 43, 1657-1678.

Ellinger, T. and Chorine, V. 1930 Sur les microbes

d'Ephestia kuhniella Zell. Compt. rend. soc. biol., $103,401-402$.

* Metalnikov, S. and Chorine, V. 1929 L'utilisation des microbes dans la lutte contre la pyrale du mais Pyrausta nubilalis $\mathrm{Hb}$. Ann. Inst. Pasteur, 43, 1391-1395.

\section{BACTERIUM EPHESTIAE No. 2 Metalnikov and Chorine (See Bacterium ephestiae No. 1.)}

\section{BACTERIUM GALLERIAE MetalnikOV}

Insects concermed: The bee moth, Galleria mellonella; the flour moth, Ephestia klhniella; the corn borer, Pyrausta nubilalis. 
Metalnikov (1922) isolated Bacterium galleriae from bee moths. Later Kitajima and Metalnikov (1923) isolated it during an epidemic from the same insects.

This organism is described as being an elongated, rodshaped, spore-forming organism, so the preferable generic name would be Bacillus.

Kitajima and Metalnikov, S. 1923 Une maladie mortelle chez les chenilles de Galleria mellonella. Compt. rend. soc. biol., 88, 476-477.

* Metalnikov, S. 1922 Une epizootie chez les chenilles de Galleria mellonella. Compt. rend. hebdom. Acad. Sci., $175,68-70$.

\section{BACTERIUM GALLERIAE No $\underline{2}$ Metalnikov and Chorine}

Insect concerned: The corn borer, Pyrausta nubilalis; the bee moth, Galleria mellonella.

Metalnikov and Chorine (1928) used this organism quite effectively in combating the corn borer. The insects turn black a few hours after death. Old cultures are as virulent as fresh cultures.

The writer has not been able to determine whether Bacterium galleriae No. $\cong$ and Bacterium galleriae are the same, though in all probability they are.

Bacterium galleriae No. 들 is a spore-former so it seems that Bacillus would be the more suitable generic name.

Metalnikov, S. and Chorine, V. 1928 The infectious diseases of Pyrausta nubilalis $\mathrm{Hb}$. Internat. Corn Borer Invest., Sci. Repts. 1 , 41-69.

BACTERIUM GELECHIAE NO 11 Metalnikov and Metalnikov

Insects concerned: The corn borer, Pyrausta nubilalis; Platyedra (Gelechia) gossypiella; Prodenia litura.

Metalnikov and Metalnikov (1932) isolated from dead or dying larvae of Platyedra (Gelechia) gossypiella, Saund, two forms of Bacterium gelechiae which they called Nos. I and 2. Both organisms produced death within 24 to 48 hours.

* Metalnikov, S. and Metalnikov, Jr., S. 1932 Maladies des vers du caton (Gelechia gossypiella et Prodenia litura). Compt. rend. acad. agr. Fr., 18, 203-207. 
BACTERIUM GELECHIAE No. 2 Metalnikov and Metalnikov (See Bacterium gelechiae No. 1.)

BACTERIUM GELECHIAE NO. 5 Metalnikov and Metalnikov Insect concerned: Platyedra gossypiella.

Metalnikov and Metalnikov (1933) isolated this organism from dead larvae of Platyedra gossypiella.

* Metalnikov, S. and Metalnikov, Jr., S. S. 1933 Utilisation des bacteries dans la lutte contre les insectes nuisbles aux contonniers. Compt. rend. soc. biol., $108,169-172$.

\section{BACTERIUM GRYLLOTALPAE Metalnikor and Meng}

Insect concerned: Gryllotalpa gryllotalpa (vulgaris, Latr. ).

This bacterium was one of two organisms isolated by Metalnikov and Meng (1935) from the diseased larvae of Gryllotalpa gryllotalpa during an outbreak in the laboratory. Bacillus gryllotalpae was the other organism.

Metalnikov, S. and Meng, L. Y. $1935^{\circ}$ Utilisation des microbes contre les courtillieres. Compt. rend. acad. sci., 201, 367-368.

\section{BACTERIUM HEBETISICCUS Steinhaus}

Insect concerned: The walking stick, Diapheromera femorata.

Steinhaus (1941) isolated this bacterium while studying the normal bacterial flora of the walking stick.

* Steinhaus, E. A. 1941 A study of the bacteria ssociated with thirty species of insects. J. Bact., 42, 757-790.

BACTERIUM HEMOPHOSPHOREUM Pfeiffer and Stammen

Insects concerned: Mamestra oleracea; the mealworm, Tenebrio molitor; the cabbage butterfly, Pieris rapae; and Agrotis sp. 
Pfeiffer and Stammer (1930) isolated this phosphorescent oryanism from the larvae of Mamestra oleracea. The organism is not identical with any of the known light producing bacterial strains pathogenic for invertebrates. Laboratory infection was possible only when the bacterial masses from the hemolymph were inoculated. Attempts to infect by mouth were not successful. The organism was found to be pathogenic for other insects also. Pfeiffer and Stammer have given a complete description of the organism.

* Pfeiffer, H. and Stammer, H. F. 1930 Pathogenes Leuchten bei Insekteri. Z. fllr Morph. und Okol der Tiere, 20, $136-171$.

\section{BACTERIUM IMPERIALE Steinhaus}

Insect concerned: The imperial moth, Eacles imperialis.

Steinhaus (1941) isolated this bacterium from the alimentary tract of Eacles imperialis. It is a gram positive short rod.

* Steinhaus, E. A. 1941 A study of the bacteria associated with thirty species of insects. J. Bact., 42, 757-790.

\section{BACTERIUM INTRINSECTUM Steinhaus}

Insect concerned: An unidentified leaf beetle (Chrysomelidae).

From the alimentary tract of an unidentified leaf beetle, Steinhaus (1941) isolated this bacterium.

* Steinhaus, E. A. 1941 A study of the bacteria associated with thirty species of insects. J. Bact., 42, 757-790.

\section{BACTERIUM ITALICUM NO. 2 Metalnikov et al.}

Insect concerned: The corn borer, Pyrausta nubilalis.

This organism was isolated from the larvae of the corn borer by Metalnikov, Ermolaev, and Skoboltzyn (1930). It is a very virulent organism killing corn borer larvae in 20 to 24 hours.

Bacterium italicum has been fully described by the above authors. Since it is a large, spore-forming rod, a more suitable generic name would be that of Bacillus. 
*Metalnikov, S., Ermolaev, J., and Skobaltzyn, V. 1930 New bacteria pathogenic to the larvae of Pyrausta nubilalis $\mathrm{Hb}$. Internat. Corn Borer Invest., Sci. Repts., 3, 28-36.

\section{BACTERIUM INCERTUM Steinhaus}

Insect concerned: The lyreman cicada, Tibicen linnei.

While studying the natural flora of the lyreman cicada, Steinhaus (1941) isolated from the ovaries of this insect, a bacterium which closely resembled those of genus Listeria (Listerella). The pathogenic characteristics were not the same as those of Listeria monocytogenes, however, so the bacterium was tentatively placed in the genus Bacterium and given the specific name incertum.

* Steinhaus, E. A. 1941 A study of the bacteria associated with thirty species of insects. J. Bact., 42, 757-790.

\section{BACTERIUM INSECT IPHILIUM Steinhaus}

Insect concerned: The bagworm, Thyridopteryx ephemeraeformis.

This bacterium was described by Steinhaus (1941) as being isolated from the body wall of the bagworm. It is a gram-positive non-spore-forming rod which hydrolyzes starch.

* Steinhaus, E. A. 1941 A study of the bacteria associatea with thirty species of insects. J. Bact., 42, 757-790.

\section{BACTERIUM KN IPOW ITCHII}

Insect concerned: The mealworm, Tenebrio molitor.

Bacterium knipowitchii, a phosphorescent bacterium, was found to be pathogenic for the mealworm by Pfeiffer and Stammer (1930).

Pfeiffer, H. and Stammer, H. J. 1930 Pathogenes Leuchten

bei Insekteri. Z. fllr. morph. und $8 k o l$ der Tiere, 20, $136-171$. 


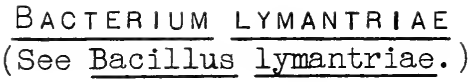

\section{BACTERIUM LYMANTRICOLA ADIPOSUS Paillot}

Insects concerned: Agrotis segetum; the gypsy moth, Porthetria dispar; the silkworm, Bombyx mori.

Paillot isolated Bacterium lymantricola adiposus in 1917 from Porthetria dispar. He (1933) studied the involution forms of the organism in the blood of Lymantria dispar; Bombyx mori, and Agrotis segetum.

Paillot, A. 1933 L'infection chez fes insects, 535 pp. Imprimerie de Trevoux, Paris. (See pp. 138-145.)

BACTERIUM MELOLONTHAE LIQUEFACIENS Paillot

Insects concerned: Melolontha vulgaris; Vanessa urticae; the cockchafer, Melolontha melolontha.

Paillot (1916) isolated Bacterium melolonthae liquefaciens from the cockchafer.

* Paillot, A. 1916 Les coccobacillus du Hanneton. Action pathogene sur quelques chenilles de macrolepidopteres. compt. rend. soc. biol., 79, 1102-1103.

BACTERIUM MELOLONTHAE LIQUEFACIENS GAMMA Paillot

Insects concerned: The gypsy moth, Porthetria (Lymantria) dispar; Euproctis chrysorrhoea; Agrotis segetum; and the cockchafer, Melolontha melolontha.

Paillot (1933) speaks of the involution forms of this organism in the blood of $\mathrm{E}$. chrysorrhoea, Porthetria (Lymantria) dispar, Agratis segetum, and Melolontha melolontha.

Bacterium melolonthae liquefaciens gamma is probably a variant of Bacterium melolonthae liquefaciens. If there is a beta strain of this organism, a reference could not be found.

Paillot, A. 1933 L'infection chez les insected, $535 \mathrm{pp}$. Imprimerie De Trevoux, Paris. (See pp. 137-138; 142143.) 


\section{BACTERIUM MINUT I FERULA Steinhaus}

Insect concerned: The mud-dauber wasp, Sceliphron cementarium.

Steinhaus (1941) isolated this bacterium from a triturated specimen of the mud-dauber wasp.

* Steinhaus, E. A. 1941 A study of the bacteria associated with thirty species of insects. J. Bact., 42 $757-790$.

\section{(See $\frac{\text { BACTERIUM MacilluS }}{\underline{B}} \frac{\text { MONACHAE }}{\text { and Bacillus monachae. }}$ )}

Insect concerned: The nun moth, Lymantria monacha.

Von Tubeuf (1892a and b) isolated this organism from the intestinal tract of the nun moth, considering it to be the causative agent of the "wilt" disease (Wipfelkrankheit). Later von Tubeuf (1911) reversed his opinion on the specific cause of the disease and concluded that it was due to a variety of intestinal bacteria becoming dominant. Since, Wahl (1909 to 1912) has shown that the disease is due to a virus.

Eckstein (1894) considered Bacterium monachae, Bacillus E. of Hofmann (1891), and Bacillus monachae to be identical organisms.

Eckstein, K. 1894 Untersuchungen ther die in Raupen vonkommenden Bakterien Z. f. Forst- und Jagdwesen, 26, 3-20; 328-241; 285-298; 413-424.

Hofmann, 0. 1891 Die Schlaffsucht (Flacherie) der nonne

(Liparis monacha) nebst einem Anhang. Inslktentotende

Pilze mit besonderer Beruchsichtigung der Nonne, 31 pp.

P. Weber, Frankfurt A. M.

*von Tubeuf, C. $1892 a$ Die Krankhe1ten der Nonne (Liparis monacha). Forstl. Naturwissensch. Z. 1, 34-47, and 62-79.

*von Tubeuf, C. 1892b Weitere Beobachtungen uber die Krankheiten der Nonne. Forstl. Naturwissensch. Z., I, 277-279.

von 'Tubeuf, C. 1911 Zur Geschichte der Nonnenkrankheit,

Naturwissensch. Z. Forst- u. Landwissensch, 2, 357. Wahl, B. 1909 tber die Polyderkrankheit der Nonne

(Lymantria monacha L.). Cent. ges. Forstwesen, 35, 164,212 . 
Wahl, B. 1910 Ibid, 36, 193, 377.

Wahl, B. 1911 Ibid, 37, 247.

Wahl, B. 1912 Ibid, $38,355$.

BACTERIUM MUTAB ILE Steinhaus

Insect concerned: The Iyreman cicada, Tibicen linnei.

This pleomorphic bacterium was isolated by steinhaus (1941) from the alimentary tract of the cicada while studying the natural flora of this insect.

* Steinhaus, E. A. 1941 A study of the bacteria associated with thirty species of Insects. J. Bact., 42, 757-790.

\section{BACTERIUM MYCOIDES}

Insect concerned: The honey bee, Apis mellifera.

White (1906) isolated Bacterium mycoides from the intestine of the honey bee. It is probably not the same as Bacterium mycoides Migula given in Bergey's Manual, since White's strain produced spores and did not produce a red pigment. It is probably the same as Bacillus mycoides.

White, G. F. 1906 The bacteria of the apiary with special reference to bee diseases. U. S. Dept. Agr., Bur. Ent., Tech. Bull. No. 14, 50 pp.

\section{BACTERIUM NEOPOLITANUM DeBach and McOmie}

Insect concerned: The termite, Zootermopsis angusticollis.

This organism caused a disease among laboratory termites, which was characterized by lethargy, cessation of feeding, etc. The insects turned black 12 to 36 hours after death, the blackness being localized in the head and appendages.

According to DeBach and McOmie (1939) the bacterium was named Bacterium neopolitanum only as a matter of convenience since it is closely related to the intestinal group according to Kluyver and van Neil nomenclature. In fact, DeBach and McOmie say that it might be called one 
of the coli-intermediates. A complete description of the organism has been given by these investigators.

* DeBach, P. H. and McOmie, W. A. 1939 New diseases of termites caused by bacteria. Annals Entomol. Soc. Am., 32, $137-146$.

\section{BACTERIUM NEUROTOMAE Paillot}

Insect concerned: Neurotoma nemoralis.

This organism was isolated in 1922 by Pailiot (1933) from the larvae of Neurotomae nemoralis. The organism is very pleomorphic, often presenting elongated forms but rarely filamented forms. Paillot states that "on gelatin a certain number of the organisms swell abnormally and transform themselves into masses more or less rounded of which the 'chromomatophize' is generally condensed in the central part. The masses present what appear to be veritable nucleated cells, but they are deprived of their vitality and rapidly degenerate."

This organism is probably the same as Bacillus neurotomae isolated by Paillot (1924).

* Paillot, A. 1924 Sur deux Bacteries parasites des

larves de Neurotoma nemoralis. Compt. rend. hebdom.

Acad. Sci., 178, 246-249.

Paillot, A. $1 \overline{933}$ L'Infection chez les insectes, $535 \mathrm{pp}$.

Imprimerie De Trevoux, Paris. (See pp. 146 and 156.)

BACTERIUM NOCTUARUM White

(See Bacillus noctuarum and Bacillus sphingidis.)

Insect concerned: The honey bee, Apis mellifera.

Metalnikov and Chorine (1928) refer to Bacterium noctuarum White saying that it resembles Coccobacillus ellingeri. It is undoubtedly Bacillus noctuarum White.

Metalnikov, S. and Chorine, V. 1928 The infectious diseases of Pyrausta nubilalis $\mathrm{Hb}$. Internat. Corn Borer .Invest., Sci. Repts., I, 41-69. 
Stutzer and Wsorow (1927) isolated Bacterium ochraceum from the intestine of healthy larvae of Euxoa segetum.

Bacterium ochraceum is probably the same as Flavobacterium ochraceum (Zimmermann) Bergey et al. found in water. Zimmermann, the original isolator of the bacterium, called it Bacillus ochraceum. (See Bergey's Manual, 5th ed., $1939, \frac{\text { p. 537.) }}{\text {. }}$

Stutzer, M. J. and Wsorow, W. J. 1927 Über Infectionen der Raupen der Winter-saatenle (Euxoa segetum Schiff.) Centr. f. Bakt. u. Parasit., 71, $113-129$.

\section{BACTERIUM ONTARIONI ChOrine}

Insect concerned: The corn borer, Pyrausta nubilalis; Ephestia klhniella; Galleria mellonella.

This organism was isolated from Canadian corn borers by Chorine (1929a, b), and experimentally, it has been shown to be very pathogenic to larvae of Ephestia kuhniella and Galleria mellonella: as well as to the corn borer larvae. This organism is a spore-former, so the correct generic name would be Bacillus. (See Bacillus ontarioni.) A complete description of the organism has been given by Chorine (1929a, b).

*Chorine, V. 1929a New bacteria pathogenic to the larvae of Pyrausta nubilalis Hb. Internat. Corn Borer Invest., Sci. Repts., $2,39-53$.

* Chorine, V. 1929b Nouveaux microbes pathogenes pour les chenilles de la'Pyrale du Mais. Ann. Inst. Pasteur, 43, $1657-1678$.

\section{BACTERIUM PARACOLI}

Insect concerned: Euxoa segetum.

Stutzer and Wsorow (1927) isolated Bacterium paracoli from the intestines of healthy larvae of Euxoa segetum.

Stutzer, M. J. and Wsorow, W. J. 1927 thber Infectionen der Raupen der Wintersaateule (Euxoa segetum Schiff).

Centr. f. Bakt. u. Parasit., 71, 113-129. 


\section{BACTERIUM "PARATYPHI Kayser}

Insect concerned: Euxoa segetum.

Bacterium paratyphi was isolated from the intestine of healthy larvae of Euxoa segetum by Stutzer and Wsorow (1927).

Salmonella paratyphi (Kayser) Bergey et al. is the accepted name for Bacterium paratyphi (Berge $\bar{y}$ 's Manual, 5th ed., 1939, p. 454.)

Etutzer, M. J. and Wsorow, W. J. 1927 ther Infectionen der Raupen der Wintersaateule (Euxoa segetum Schiff.)

Centr. f. Bakt. u. Parasitenk., 71, 113-129.

BACTERIUM PIERIS LIQUEFACIENS ALPHA PailIOt

Insects concerned: Pieris brassicae; Vanessa urticae; Vanessa polyschloros; Euproctis chrysorrhoea; Porthetria dispar.

Paillot (1933) found Bacterium pieris liquefaciens alpha to be very pleomorphic, its shape depending upon the insect it parasitized. In the blood of the larvae of Pieris brassicae, from which it was isolated, the "bacterial elements are in the form of coccobacilit;. . In the larvae of Vanessa polyschioros $I$., the longer elements are considers.bly longer" than in the above larvae. In the larvae of Iymantria dispar I. the organism lost all aspects of a coccobacilius and was transformed into veritable filaments, some as long as 40 microns. These morphological changes did not affect the vital and biochemical properties of the organism.

Pailiot, A. 1933 I'Infection chez les Insectes, 535 pp. Imprimerie De Trevoux, G. Patissier. (See pp. 135-137; $145-147.)^{\circ}$

\section{BACTERIUM PITYOCAMPAE DufrenOy}

Insect concerned: The processionary caterpillars of pines, Cnethocampa pityocampa.

Dufrenoy (1919) isolated three pathogenic organisms from the above insect: Bacterium pityocampae, Streptococcus pityocampae alpha, and streptococcus pityocampae beta. Bacterium pityocampae according to Paillot (1933), is a Gram negative, encapsulated organism. 
*Dufrenoy, J. 1919 Les formes de dégénérescence des chenilles de Cnethocampa pityocampa parasitées., Compt. rend. soc. biol., 82, 288-289.

Paillot, A. 1933 L'Infection chez les insectes, 535 pp. Imprimerie de Trevoux, Paris. (See pp. 125-126.)

BACTERIUM PRODENIAE Metalnikov and Metalnikov

Insect concerned: Prodenia litura.

Metalnikov and Metalnikov (1932) isolated this organism from larvae of Prodenia litura while studying diseases of this insect and those of Gelechia gossypiella.

* Metalnikov, S. and Metalnikov, Jr., S. 1932 Maladies des vers du Coton (Gelechia gossypiella et Prodenia litura.) Compt. rend. acad. agri. Fr., 18, 203-207.

BACTERIUM PRODIGIOSUM Lehman and Neumann (See Serratia marcescens.)

BACTERIUM PRODIGIOSUS (See Serratia marcescens.)

$\frac{\text { BACTER IUM }}{\text { (See }} \frac{\text { PSEUDOTSUGAE Hansen and Smith }}{\text { Phytomonas pseudotsugae.) }}$

BACTERIUM PYRAUSTAE NOS. 1-7 Metalnikov and Chorine

Insect concerned: Corn borer, Pvrausta nubilalis $\mathrm{Hb}$.

Metalnikov and Chorine (1928) isolated seven pathogenic bacteria from diseased corn borers which had been collected from mugwort plants around Paris. The authors considered them to be of little importance because they were not able to infect corn borers by mouth, so the organisms were merely numbered. No. 1 was found to be very virulent for corn borer larvae when injected. The workers have briefly described the biological characteristics of each of these in tabular form. 
* Metalnikor, S. and Chorine, V. 1928 The infectious diseases of Pyrausta nubilalis Hb. Internat. Corn Borer Invest., Sci. Repts., 1, 41-69.

\section{BACTER IUM PYRENEI Metalnikov et al. (See Bacterium pyrenei No. 1.)}

Insects concerned: The corn borer, Pyrausta nubilalis Hb., Pieris brassicae; Porthetria dispar L.; Vanessa urticae L.; Stilpnotia salicis L.; Ephestia kthniella Zell.; and Aporia crataegi L.

Metalnikov (1930) found Bacterium pyrenei to be virufor the larvae of the above insects.

Metalnikov, S. 1930 Utilisation des microbes dans la lutte contre Lymantria et autres insectes nuisbles.

Com. rend. soc. biol. 105, 535-537.

Sweetman, H. I. 1936 Biological Control of Insects, $461 \mathrm{pp}$. Comstock Publishing Co., Inc., Ithaca, N. Y. (See pp. 56-57).

\section{BACTERIUM PYRENEI No. 1 Metalnikov et al.}

Insect concerned: Corn borer, Pyrausta nubilalis Hb.

This organism was isolated by Metalnikov, Ermolaev, and Skobaltzyn (1930) from dead, black larvae of corn borers that had been received from the Pyrenees. Two other organisms, Bacterium pyrenei No. 2 and Bacterium pyrenei No. 3 were isolated from the same larvae. The authors, pending complete analysis, gave the bacteria provisional names. All three strains were very pathogenic for the corn borer larvae and for other lepidoptera larvae, which often died in 10 to 15 hours when infected by mouth with a virulent strain. The present author was unable to find subsequent reference to these organisms other than Metalnikov (1930) and Sweetman (1936) who refer only to a Bacterium pyrenei.

The three strains are all spore-forming, so the generic name should be Bacillus.

*Metalnikov, S., Ermolaev, J., and Skobaltzyn, V. 1930

New bacteria pathogenic to the larvae of Pyrausta nubilalis Hb., Internat. Corn Borer Invest., Sci. Repts., 3, 28-36. 
Metalnikov, S. 1930 Utilisation des microbes dans la lutte contre Lymantria et autres insectes nuisbles. Compt. rend. soc. biol., 105, 535-537.

Sweetman, H. L. 1936 Biological Control of Insects, $461 \mathrm{pp}$. Comstock Publishing Co., Inc., Ithaca, N. Y. (pp. 45-60.)

BACTERIUM PYRENEI No. 2 Metalnikov et al. (See Bacterium pyrenei No. 1:) $\frac{\text { BACTER IUM }}{\text { (See }} \frac{\text { PYRENEI Noterium }}{\text { pyrenei No. 1.) }} \frac{3}{\text { Metalnikov et al. }}$

\section{BACTERIUM QUALIS Steinhaus}

Insect concerned: The tarnished plant bug, Lygus pratensis.

Steinhaus (1941) found this bacterium in the alimentary tract of the tarnished plant bug.

* Steinhaus, E. A. 1941 A study of the bacteria associated with thirty species of insects. J. Bact., 42, 757-790.

\section{BACTERIUM RUBRUM}

Insect concerned: Platyedra (Gelechia) gossypiella.

Metalnikov and Metalnikov (1932) isolated this organism from the larvae of Platyedra (Gelechia) gossypiella, Saund.

Schneider isolated an organism from swamp water in 1894 which he called Bacterium rubrum (see Bergey's Manual, 5th ed., 1939, p. 636). The writer was unable to determine whether these two organisms were the same or not.

Metalnikov, S. and Metalnikov, Jr., S. 1932 Maladies des vers du Caton (Gelechia gossypiella et Prodenia litura). Compt. rend. acad. agric. Fr., 18, 203-207.

(See Phytomonas savastanoi.) 


\section{BACTERIUM SPHINGIDIS White}

(See Bacillus sphingidis)

Metalnikov and Chorine (1928) state that this organism resembles Coccobacillus ellingeri. It is undoubtedly Bacillus sphingidis White.

Metalnikov, S. and Chorine, V. 1928 The infectious diseases of Pyrausta nubilalis $\mathrm{Hb}$. Internat. Corn Borer Invest., Sci. Repts. 1, 41-69.

\section{BACTERIUM TEGUMENT ICOLA Steinhaus}

Insect concerned: The bedbug, Cimex lectularius.

The integument of several specimens of Cimex lectularius was found to harbor this bacterium which has been described by Steinhaus (1941).

*Steinhaus, E. A. 1941 A study of the bacteria associated with thirty species of insects. J. Bact., 42, 757-790.

\section{BACTERIUM TERMO Gillette}

Insects concerned: Grasshoppers, Melanoplus bivittatus and M. femur-rubrum.

Gillette (1896) isolated this organism from grasshoppers in Colorado. According to Smith (1933) the hoppers generally died on the ground, their bodies turning black and their vital organs disintegrating. According to Jordan and Burrows (1941) Bacterium termo is synonymous with Proteus vulgaris.

*Gillette, G. P. 1896 The grasshopper disease in Colorado. U. S. Bur. Ento., Bul. 6, 89-93. Jordan, E. O. and Burrows, W. 1941 Textbook of Bacteriology, l3th edition, 731 pp. W. B. Saunders Co., Philadelphia. (See p. 415)

Smith, R. C. 1933 Fungous and bacterial diseases in the control of grasshoppers and chinch bugs. 28th biennial Rept. Kan. St. Bd. Agr., 44-58. 


\title{
BACTERIUM THURINGIENSIS Berliner
}

(See Bacillus thuringiensis)

Insects concerned: The corn borer, Pyrausta nubilalis; Ephestia kthniella; Stilpnotia salicis; Aporia crataegi; Vanessa urticae L.

Metalnikov and Chorine (1929a, b) state that Bacterium thuringiensis Berliner is pathogenic for the corn borer and the gypsy moth. They are referring to Bacillus thuringiensis. (See Bacterium thuringiensis No. 1.)

Metalnikov, S. and Chorine, V. 1929a Experiments on the use of bacteria to destroy corn borer. Internat. Corn Borer Invest., Sci. Repts., ?, 54-59. Metalnikov, S. and Chorine, V. $1929 \mathrm{~b}$ on the infection of the gypsy moth and certain other insects with Bacterium thuringiensis. Ibid, 60-61.

BACTERIUM THURINGIENS IS No. i Metalnikov and Chorine (See Bacillus thuringiensis.)

Insects concerned: The corn borer, Pyrausta nubilalis; and the gypsy moth, Ephestia kllhniella.

Ellinger and Chorine (1930) state: "Two strains of bacteria that were isolated from Ephestia klhniella Zel.l. by Metalnikov and Chorine and utilized by them against Pyrausta nubilalis $\mathrm{Hb}$. and were referred to as Bacterium thuringiensis Nos. 1 and 2. . are identical with Bacillus thuringiensis isolated by Berliner . . ."

Ellinger, T. and Chorine, V. 1930 Sur les Microbes d'Ephestia kllhniella Zell. Compt. rend. soc. biol., $10 \overline{3}, 401-40 \overline{2}$.

BACTERIUM THURINGIENSIS No. 2 Metalnikov and Chorine (See Bacterium thuringiensis No. 1.)

\author{
BACTERIUM TULARENSE \\ (See $\overline{\text { Pasteurella tularensis. ) }}$
}




\section{BACTERIUM TUMEFACIENS Smith and TOwnsend (See Phytomonas tumefaciens.)}

Insect concerned: Galleria mellonella.

This organism was found in the larvae of Galleria mellonella by Metalnikov et al. (1924). It is most likely the same as Phytomonas tumefaciens (see Bergey's Manual, 1939, 5th ed., page 208).

Metalnikov, S., Kostritsky, L., and Toumanoff, H. 1924 Bacterium tumefaciens chez les chenilles de Galleria mellonella. Compt. rend. Acad. Sci., 179, 225-227.

\section{BACTERIUM VISCOSUM NON-LIQUEFACIENS}

\section{Insect concerned: Euxoa segetum.}

Stutzer and Wsorow (1927) isolated Bacterium viscosum non-liquefaciens from the normal pupae of the Euxoa segetum.

Stutzer, M. J. and Wsorow, W. J. 1927 Über Infectionen der Raupen der Wintersaateule (Euxoa segetum Schiff.) Centr. f. Bakt. u. Parasit., 71, 113-129.

\section{Genus: Flavobacterium}

\section{FLAVOBACTERIUM ACIDIFICUM Steinhaus}

Insects concerned: The grasshopper, Conocephalus fasciatus var. fasciatus; the Colorado potato beetle, Leptinotarsa decemlineata; the cabbage butterfly, Pieris rapae; and an unidentified lady beetle larvae.

Steinhaus (1941) isolated Flavobacterium acidificum from the above insects while studying their normal bacterial flora.

* Steinhaus, E. A. 1941 A study of the bacteria associated with thirty species of insects. J. Bact., 42, 757-790. 


\section{FLAVOBACTER IUM CHLORUM Steinhaus}

Insect concerned: The nine-spotted lady beetle, Coccinella novemnotata.

This bacterium was isolated from the alimentary tract of the nine-spotted lady beetle by Steinhaus (1941).

* Steinhaus, E. A. 1941 A study of the bacteria associated with thirty species of insects. J. Bact., 42 , 757-790.

\section{FLAVOBACTERIUM DEVORANS (Zimmermann) Bergey et al.}

Insect concerned: Coccinella novemnotata.

Steinhaus (1941) found a species of bacteria very similar to Flavobacterium devorans in the alimentary tract of Coccinella novemnotata collected in nature. A description of this organism may be found in Bergey's Manual (1939, 5th ed., page 528).

Steinhaus, E. A. 1941 A study of the bacteria associated with thirty species of insects. J. Bact., 42, 757-790.

\section{FLAVOBACTERIUM $\frac{\text { FERMENTANS }}{\text { Bergey et al. }}$ (von Wolzogen Kthrr)}

Insect concerned: The midge, Chironomus plumosus.

This organism, isolated from the larvae of the midge, Chironomus plumosus, called Pseudomonas fermentans by von Wolzogen Kthr (1932) and is so designated in the 5 th edition of Bergey's Manual, 1939, page 612. However, in 4 th edition of Bergey's Manual, 1934, 155, the organism was named Flavobacterium fermentans. A complete description of this organism may be found in either of these two editions of Bergey's Manual.

von Wolzogen Kthrr, C. A. H. 1932 Über eine GḦrungsmikrobe in Flakalien von Muckenlarven. Cent. f. Bakt. u. Parasitenk., II Abt., 85, 223-250. 
Insect concerned: The Calpha sphinx, Ceratomia catalpae.

From the mid-intestine of the larva of Ceratomia catalpae, Steinhaus (1941) isolated a gram positive bacterium which in many of its characteristics was similar to Flavobacterium maris. The two organisms may not be identical (they differed in a few of their physiologic reactions) but until this group is better defined Steinhaus considered the organisms to be similar. A description of Flavobacterium maris may be found in Bergey's Manual (1939, 5th ed., page $\overline{552 .}$ )

Steinhaus, E. A. 1941 A study of the bacteria associated with thirty species of insects. J. Bact., 42, 757-790.

\section{FLAVOBACTERIUM RHEN I}

Insect concerned: The walking stick, Diapheromera femorata Say.

Steinhaus (1941) isolated an organism similar to Flavobacterium rheni from eggs about to be laid of the walking stick. A description of the organism may be found in Bergey's Manual.

Steinhaus, E. A. 1941 A study of the bacteria associated with thirty species of insects. J. Bact., 42, 757-790.

\section{FLAVOBACTERIUM OCHRACEUM (Zimmermann) Bergey et al. \\ (See Bacterium ochraceum.)}

Genus: Fusobacterium

(Fusiformis Próvot)

\section{FUSIFORMIS TERMITIDIS HOelling}

Insect concerned: Termites, including Calotermes (Glyptotermes) iridipennis.

According to Dougherty (1942), Hoelling (1910) described a fusiform bacterium, which he called Fusiformis termitidis, 
from smears of the intestinal tracts of termites. Dubosca and Grasse (1927) found this microorganism in Calotermes (Glyptotermes) iridipennis.

Dougherty, E. C. 1942 Unpublished manuscript. Duboscq, 0., and Grasse, P. 1927 Flagelles et schizophytes de Calotermes (Glyptotermes) iridipennis Frogg. Arch. Zool. Exp. Gen., 66, 451-496.

* Hoelling, B. A. 1910 Die Kernverhaltnisse von Fusiformis termitidis. Arch. Protistenk. 19, 239.

FUSIFORMIS HILLI Duboscq and Grasse

Insect concerned: The termite, Calotermes (Gyptotermes) iridipennis.

Duboscq and Grasse (1927) isolated an organism, which they named Fusiformis hilli, from the termite Glyptotermes iridipennis.

*Duboscq, 0., and Grasse, P. 1927 Flagelles et schizophytes de Calotermes (Glyptotermes) iridipennis Frogg. Arch. Zool. Exp. Gen., 66, 451-496.

Family: ENTEROBACTER I ACEAE

Tribe: ERW INEAE

Genus: Erwinia

ERW INIA AM LOVORA (Burrill) Winslow et al.

Insects concerned: Adelphocoris rapidus; Campyloma verbasci; Lygus pratensis; Orthotylus flavosparsus; Plagiognathus politus, Poecilo cytus basalis; Empoasca mali; Aphis avenae; Aphis pomi ; Hoppodamia convergens; Diabrotica soror; Orsodacne atra; Attagenus piceus; Anthrenus sp.; Glischrochielus fasciatus; Melanotus oregonensis; Scolytus rugulosus; Carpocapsa pomonella;

Bibio albipennis; Drosophila funebris; Hylemyia antiqua; Hylemyia lipsia; Pegomyia calyptrata; Cynomyia cadaverina; Musca domestica; Muscina assimilis; Muscina stabulans;

Formica fusca var. subsericea; Formica pallidefulva subsp. schaufussi var. incerta; Lasius niger var americanus; Prenolepis imparis; Polistes sp.; Vespula sp.; Drosophila malanogaster; Lucilia seriata. 
Fire blight has a very interesting history. Burrill (1881) was the first to prove that bacteria can be the cause of a plant disease and it was he (1882) who isolated the causative organism of fire blight, Micrococcus amylovorus. For a description of the disease see Elliott (1930) and Leach (1940). Waite (1891) was one of the first who advanced experimental proof that insects were important vectors of plant diseases when he showed that bees and wasps were transmitters of fire blight.

According to Leach (1940), fire blight is principally a disease of pears and apples although other orchard fruits as well as many ornamental plants are often affected. More than 90 species of plants, mostly in the family Rosaceae, are hosts to the disease.

The literature on this disease is contradictory as well as voluminous. Concerning this state of affairs Leach (1940) states: "It is somewhat ironical that the first association between insect and plant disease to be established should, after 50 years, remain in such an uncertain and unsatisfactory state." Many theories of insect transmission have been advanced and many insects have been incriminated, in some cases without adequate proof.

of the recent work on the association of this disease with insects, that of Ark and Thomas (1936) seems quite important. These workers have shown that Erwinia amylovora may live for several days in the intestinal tract of Drosophila melanogaster, Lucilia seriata, and Musca domesiica. The eggs of Musca domestica, which had been laid by contaminated females, were found to harbor externally the pathogen. Furthermore, bacteria fed to the larvae of Drosophila melanogaster and Musca domestica persisted through the puparia and could be found associated with the emerging adult.

For descriptions of Erwinia amylovora see Elliott (1930) and Bergey's Manual (1939, 5th ed., pages 405-406).

Ark, P. A., and Thomas, H. E. 1936 Persistence of Erwinia amylovora in certain insects. Phytopath., 18, 459.

Burrill, T. J. 1881 Anthrax of fruit trees; or the socalled fire-blight of pear and twig blight of apple trees. Proc. Amer. Assoc. Adv. Sci., 29, 583-597.

*Burrill, T. J. 1882 The bacteria; An account of their nature and effects together with a systematic description of the species. Rept. Illinois Industr. Univ., ll, $126,134$.

Elliott, C. 1930 Manual of bacterial plant pathogens. 349 pp. Williams and Wilkins Company, Baltimore. 
Leach, J. G. 1940 Insect transmission of plant diseases.

615 pp. McGraw-Hill Book Company, New York.

Waite, M. B. 1891 Results from recent investigations in pear blight. Bot. Gas., 16, 259.

\section{ERWINIA CACTICIDA (Johnson and Hitchcock)}

Hauduroy et al.

Insects concerned: Molitara prodenialis; Olyca junctoliniella; Mimorista flavidissimalis; Moneilema spp.; and several members of the Drosophilidae.

Johnston and Hitchcock (1923) described and named a bacterium (Bacillus cacticidus) which causes a disease of prickly pear (Opuntia spp.). This bacterial strain has since been called Erwinia cacticida, although Bergey's Manual (1939, 5th ed.. page 412) states that this organism is regarded as being the same as Erwinia aroideae (Townsend) Holland.

According to Leach (1940) it has been shown that the larvae of the above-named insects may transmit the disease. Not only do the insects transmit the disease from plant to plant but from one segment to another of the same plant as well.

Johnston, T. H., and Hitchcock, L. 1923 A bacteriosis of prickly pear plants (Opuntia spp.). Trans. and Proc. Roy. Soc. South Australia, 47, 162-164. Leach, J. G. 1940 Insect transmission of plant diseases.

615 pp. McGraw-Hill Book Company, New York.

\section{ERW INIA CAROTOVORA (Jones) Holland}

Insects concerned: Hylemyia cilicrura; Hylemyia trichodactyla; Hylemyia brassicae; Elachiptera costata; scaptomyza graminum, Phorbia fusiceps.

Erwinia carotovora causes a soft rot in carrot, celery, eggplant, cabbage, cucumber, iris, muskmelon, hyacinth, turnip, tomato, potato, onion, radish, parsnip, pepper, and other plants. The three principle types of disease caused by this bacterium are potato blackleg, soft rot of crucifers, and heart rot of celery. Jones first isolated the causative organism in 1901 and named it Bacillus carotovorus.

The work of Leach (1925, 1926, 1927, $\overline{1930), \text { Bonde (1930a, }}$ 1930b, 1939), and Johnson (1930) have shed a great deal of 
light on Erwinia carotovora and its relationship with insects. For descriptions of the organism and the disease see Bergey's Manual (1939, 5th ed., pages 409-410), Leach (1940), and Bacillus carotovorus in Elliott (1930).

Bonde, R. 1930a The cabbage maggot as a disseminating agent of bacterial rots in the Cruciferae. Phytopath., $\underline{20}, 128$.

Bonde, R. $1930 \mathrm{~b}$ some conditions determining potato-seedpiece decay and blackleg induced by maggots. Phytopath., $\underline{20}, 128$.

Bonde, R. 1939 The role of insects in the dissemination of potato blackleg and seed-piece decay. J. Agr. Research, 59, 889-917.

Elliott, C. 1930 Manual of bacterial plant pathogens, $349 \mathrm{pp}$. Williams and Wilkins Company, Baltimore. (See pages $39-45$. )

Johnson, D. E. 1930 The relation of the cabbage maggot and other insects to the spread and development of soft rot of Cruciferae. Phytopath., 20, 857-872. * Jones, I. R. 1901 Bacillus carotovorus n. sp. die Ursache einer weichen Faulnis der Mohre. Centr. Bakt., I, $12-21,61-68$.

Leach, J. G. 1925 The seed-corn maggot and potato blackleg. Science, 61, 120.

Leach, J. G. 1926 The relation of the seed-corn maggot

(Phorbia fusciceps Zett.) to the spread and development of potato blackleg in Minnesota. Phytopath., 16, 149176.

Leach, J. G. 1927 The relation of insects and weather to the development of heart rot of celery. Phytopath., 17, 663-667.

Leach, J. G. 1930 The identity of the potato blackleg pathogen. Phytopath., 20, 743-751.

Leach, J. G. 1940 Insect transmission of plant diseases, 165 pp. McGraw-Hill Book Company, New York.

(See $\frac{\text { ERW INIA LATHYR L L }}{\text { Latilus }}$

ERW INIA TRACHEIPHILA (Smith) HOlland

Insects concerned: The twelve-spotted cucumber beetle, Diabrotica duodecimpunctata, and the striped cucumber beetle, Diabrotica vittata. 
Erwin F. Smith first described cucurbit wilt in 1893. Somewhat later Smith suggested that insects might be responsible for the dissemination of the disease. It was not until 1915, however, when Rand advanced experimental proof incriminating the two cucumber beetles listed above. Rand and Cash (1920) have shown that the adult beetle of Diabrotica vittata may harbor the bacteria in its body over winter.

See Bergey's Manual (1939, 5th ed., page 417) for a description of this bacterium.

Rand, F. V. 1915 Dissemination of bacterial wilt of cucurbits. J. Agr. Research, 5, 257-260.

Rand, F. V., and Cash, L. C. 1920 Some insect relations of Bacillus tracheiphilus. Phytopath., 10, 133-140. * Smith, E. F. 1893 Two new and destructive diseases of cucurbits. Bot. Gaz., 18, 339.

\section{Tribe: ESCHERICHEAE}

Genus: Aerobacter

\section{AEROBACTER AEROGENES (Kruse) Beijerinck}

Iracts concerned: Euxoa segetum; the cabbage butterfly, Pieris rapae; Pentatomidae (probably Loxa variegata); the potato beetle, Leptinotarsa decemlineata; the meadow grasshopper, Conocephalus fasciatus, var. fasciatus; the cricket, Neombius fasciatus var. fasciatus; and Urographus fasciata.

Stutzer and Wsorow (1927) found Bacillus lactis aerogenes [Aerobacter aerogenes] to be part of the normal flora of the intestines of healthy caterpillars of Euxoa segetum. Steinhaus (1941) isolated it from the intestinal tracts of the above listed insects (Euxoa segetum excepted).

A complete description of the Aerobacter aerogenes may be found in Bergey Manual ( 5 th edition, p. 396).

Steinhaus, E. A. 1941 A study of the bacteria associated with thirty species of insects. J. Bact., 42, 757-790. Stutzer, M. J. and Wsorow, W. J. 1927 Veber Infectionen der Raupen der Wintersaatenle (Euxoa segetum Schiff.) Centr. f. Bakt. u. Parasit., 71, 113-129. 
AEROBACTER BOMBYCIS Bergey et al.

(See Proteus bombycis.)

Insect concerned: The silkworm, Bombyx mori.

Glaser (1924) isolated and described this organism from diseased silkworms but he did not name it. Bergey et al. named it Aerobacter bombycis in both the $3 \mathrm{~d}$ and 4 th editions of the Manual (3d ed., 1930, p. 334; 4th ed., 1934, p. 365). In the edition (see p. 436) the organism has been called Proteus bombycis Bergey et al. Lehmann (1931) named the organism Bacterium bombycivorum.

Glaser, R. W. 1924 A bacterial disease of silkworms. J. Bact., 2, 339-352.

Lehmann-Nevunann-Breed, 1931 Determinative Bacteriology,

G. E. Stechert and Co., New York, $868 \mathrm{pp}$.

\section{AEROBACTER CLOACEA (Jordan) Bergey et al.}

Insects concerned: The German roach, Blattella germanica; the honey bee, Apis mellifera; the cabbage butterfly, Pieris rapae; the blister beetles, Epicauta pennsylvanica. and Epicauta cinerea, var. marginata.

White (1906) isolated Bacillus cloacae (Aerobacter loacae) from the intestine of the healthy honey bee.

During a survey of the natural bacterial flora of 30 species of insects, Steinhaus (1941) found coliform bacteria of the Aerobacter cloacae type in the alimentary tracts of the German roach, cabbage butterfly, and two species of blister beetles.

See Bergey's Manual (1939, 5th ed., page 398) for a complete description of this bacterium.

Steinhaus, E. A. 1941 A.study of the bacteria associated with thirty species of insects. J. Bact., 42, 757-790. White, G. F. 1906 The bacteria of the apiary with special reference to bee diseases. U. S. Dept. Agr., Bur. Entomol., Tech. Bull. No. 14, $50 \mathrm{pp}$.

Genus: Escherichia 
Genus: Escherichia

ESCHERICHIA COLI (Migula) Castellani and Chalmers (See also Bacterium coli and Bacillus coli communis.)

Insects concernes: The silkworm, Bombyx mori; the honey bee, Apis mellifera; the cockroach, probably Periplaneta orientalis; the fly, Chrysomyia megacephala; the German roach, Blattella germanica; the cecropia moth larva, Platysamia cecropia; Paria canella, var. gilvipes; the lady beetle, Coccinella novemnotata; the cricket, Neombius fasciatus var. fasciatus.

Sawamura (1906) lists Bacillus coli (Escherichia coli) as one of the organisms capable of experimentally producing flacherie in silkworms. White (1906) isolated Bacillus coli communis (E. coli) from the intestinal tract of the honey bee. Longfellow (1913) found that the cockroach carried Bacillus coli communis on its legs. Over 80 percent of the Chrysomyia megacephala caught in Peiping were found by Chow (1940) to be infected with "Bact. coli." In a survey of the natural bacterial flora of thirty species of insects, Steinhaus (1941) isolated Escherichia coli from the alimentary tracts of the German roach, the Cecropia moth larva, the Paria canella var. gilvipes, the leky beetle, and the cricket.

A complete description of Escherichia coli may be found in Bergey's Manual (1939, 5th ed., page 389).

Chow, C. Y. 1940 The common blue-bottle fly, Chrysomyia megacephala, as a carrier of pathogenic bacteria in Peiping, China. Chinese M. J., 57, 145-153. Longfellow, R. C. 1913 The common house roach as a carrier of disease. Am. J. Public Health, 3, 58-61. Sawamura, S. 1906 Note on bacteria pathogenic to silkworm. Tokyo Imp. Univ. Coll. Agri. Bull., I, 105. Steinhaus, E. A. 1941 A study of the bacteria associated with thirty species of insects. J. Bact. 42, 757-790. White, G. F. 1906 The bacteria of the apiary with special reference to bee diseases. U. S. Dept. Agr., Bur. Entomol., Tech. Bull. No. 14, 50 pp. 
ESCHERICHIA FREUNDII (Braak) Bergey et al.

Insects concerned: The cecropia moth caterpillar, Platysamia cecropia; Paria canella, var. gilvipes.

Coliform bacteria similar to Escherichia freundii were isolated from the alimentary tracts of the above-listed normal insects by Steinhaus (1941).

For a complete description of this bacterium see Bergey's Manual (1939, 5th ed., page 394).

Steinhaus, E. A. 1941 A study of the bacteria associated with thirty species of insects. J. Bact., 42, 757-790.

ESCHERICHIA NOCTUARII Bergey et al.

(See Bacillus nocturarum and Bacillus sphingidis.)

ESCHERICHIA SPHINGIDIS Bergey et al. (See Bacillus sphingidis.)

Genus: Klebsiella

KLEBSIELLA CAPSULATA (Sternberg) Bergey et al.

Insect concerned: The army worm, Barathra configurata.

Munro (1936) studied an epidemic of septicemia among Bertha army worms in North Dakota in collaboration with Nelson, who isolated an organism which he identified as Klebsiella capsulata.

Munro, J. A. 1936 Disease checks Bertha army worms. J. Econ. Ent., 29, 218.

KLEBSIELLA PARALYTICA Cahn, Wallace and Thomas

Tick concerned: The tick Dermacentor albipictus.

In 1932, Thomas and Cahn described a disease among a species of moose (Alces americana americana) in northeastern Minnesota and the adjacent region of Ontario, Canada. The moose in this area were heavily infested by the tick Dermacentor albipictus, the final stage of the 
tick appearing in the spring coincident with the appearance of the disease. Ticks taken from moose dying of the disease transmitted it to guinea pigs and rabbits in the laboratory. A bacterium, which Cahn, Wallace, and Thomas (1932) named Klebsiella paralytica, was isolated from these ticks taken from diseased moose. When this bacterium was injected into animals, symptoms were produced similar to those in the tick-infested laboratory animals and in the diseased mose. Sumarizing their experiments, Wallace, Cahn, and Thomas (1933) state, "while we have not proved that Klebsiella paralytica is the cause of moose disease, we have presented a series of observations which strongly indicate that it may be the cause."

See Bergey's Manual, 5th ed., p. 402, for a description of this organism.

*Cahn, A. R., Wallace, G. I., and Thomas, L. J. 1932 A new disease of moose. III. A new bacterium. Science, 76 , 1974.

Thomas, L. J., and Cahn, A. R. 1932 A new disease of moose. I. Preliminary report. J. Parasitol., 18, 219231.

Wallace, G. I., Cahn, A. R., and Thomas, L. J. 1933 Klebsiella paralytica a new pathogenic bacterium from "moose disease." J. Infectious Diseases, 53, 386-414.

\section{Tribe: PROTEAE}

Genus: Proteus

\section{PROTEUS ALVEICOLA SerbinOW}

Insect concerned: The honey bee, Apis mellifera.

Serbinow (1915) attributed the cause of infectious diarrhoea of silkworms to be due to Proteus alvelcola and Bacterium coli apium. Both organisms were infectious for mice by peritoneal inoculation.

Serbinow, I. L. 1915 J. Microbiol. Petrograd, 2, 19.

$$
\frac{\text { PROTEUS }}{\text { (See AOMBYCIS Bergey et al. }}
$$

Called Aerobacter bombycis in third and fourth editions of the Bergey Manual, though the fifth edition, 1939, p. 436, uses the name Proteus bombycis. 


\section{PROTEUS INSECTICOLENS StEInhaus}

Insect concerned: The milkweed bug, Oncopeltus fasclatus.

Steinhaus (1941) isolated this species from the four stomachs of the milkweed bug.

* Steinhaus, E. A. 1941 A study of the bacterla associated with thirty species of insects. J. Bact., 42, 757-790.

PROTEUS NOCTUARUM Bergey ot al. (See Bacillus noctuarum and Bacillus sphingidis.)

\section{PROTEUS PHOTURIS BrOWn}

Insect concerned: The firefly, Photuris pennsylvanicus.

Brown (1927) isolated this organism from the luminous organ of firefiles. He states that the organism appears to be a normal symbiotic inhabitant of that organ. A complete description of the organism has been given by Brown.

*Brown, F. M. 1927 Description of new species of bacteria found in insects. Am. Mus. Novit., No. 251, 11 pp.

\section{PROTEUS RECTICOLENS Steinhaus}

Insect concerned: The milkweed bug, Oncopeltus fasciatus.

The pylorus and rectum of the milkweed bug were found by Steinhaus (1941) to contain large numbers of this bacterium as part of its normal flora.

* Steinhaus, E. A. 1941 A study of the bacteria associated with thirty species of insects. J. Bact., 42, 757-790.

$\frac{\text { PROTEUS }}{\text { SPHINGIDIS Bergey et al. }}$

PROTEUS VULGARIS Hauser

Insect concerned: The cockroach, probably Periplaneta orientalis; the bee moth, Galleria mellonella. 
Longfellow (1913) found that cockroaches carried Proteus vulgaris on their legs.

Metalnikov (1920) in carrying out a series of experiments to determine the immunity of the nun-moth to certain organisms, found that the insect larva offered no resistance at all to even small doses of Bacillus proteus (Proteus vulgaris.) However, Metalnikov and Gaschen (1921) found they could produce immunity by injection of a vaccine, which carried over into the adult stage.

A description of Proteus vulgaris may be found in Bergey's Manual (5th ed., p. 431).

Longfellow, R. C. 1913 The common house roach as a carrier of disease. Am. J. Public Health, 3, 58-61. Metalnikov, S. 1920 Immunité de la chenille contre divers microbes. Compt. rend. soc. biol., 83, 119-121. Metalnikov, S. and Gaschen, H. 1921 Compt. rend. soc. biol., 85, 224 .

\section{Tribe: SALMONELLEAE}

Genus: Eberthella

\section{EBERTHELLA INSECT ICOLA Steinhaus}

Insects concerned: The meadow grasshopper, Conocephalus fasciatus var. fasciatus; the milkweed bug, Oncopeltus fasciatus; and the stink bug, probably Loxa variegata.

Steinhaus (1941) isolated Eberthella insecticola from the alimentary tracts of the above insects. Relatively large inocula of some of the strains were pathogenic to mice.

* Steinhaus, E. A. 1941 A study of the bacteria associated with thirty species of insects. J. Bact., 42, 757-790.

\section{EBERTHELLA PYOGENES (Migula) Bergey et al.}

Insect concerned: The cricket, Neombius fasciatus, var. fasciatus.

An organism similar to Eberthella pyogenes was isolated by Steinhaus (1941) from the alimentary tract of specimens of the above cricket that had been collected in nature. Eberthella pyogenes is described in Bergey's Manual (5th ed., p. 466). 
Steinhaus, E. A. 1941 A study of bacteria associated with thirty species of insects. J. Bact., 42, 757-790.

\section{EBERTHELLA TYPHOSA (ZOpf) Weldin}

Insects concerned: The house fly, Musca domestica; the blue-bottle fly, Chrysomyia megacephala; the cockroach, Periplaneta americana; the mosquito, Aedes aegypti; and ants.

A great deal has been written concerning the transmission of Euerthella typhosa by insects. The most often incriminated insect is the common house fly, Musca domestica. The typhoid bacilli may contaminate the body and appendages of the fiy or they may occur in the contents of the intestinal tract or in the feces of the insect, thereby contaminating food and drink.

One of the earliest definite reports incriminating the house fly in this regard was made by the Army Commission appointed to investigate the cause of epidemics of enteric fever in the Army camps of the Southern United States during the Spanish-American War. This commission attributed about 15 per cent of the cases of typhoid fever to transmission by flies. Hamilton (1903) isolated typhoid bacilli from flies caught in houses in which were patients ill with typhoid fever. Ficker (1903) allowed flies to feed on pure cultures of Eberthella typhosa and was able to culture the bacilli from crushed flies 5 to 23 days afterwards. Faichnie (1909a, 1909b) concluded from his experiments that typhoid bacilli are not as readily transmitted via the legs of flies as by the excrement of flies. These examples represent the earlier work which incriminated the fly as a carrier of Eberthella typhosa. (See also Howard, 1911; and Graham-Smith, 1913). Since these investigations, the evidence that flies, particularly Musca domestica, nay transmit the typhoid bacillus has been fairly well completed.

Experimentally, Chow (1940) found Eberthella typhosa as well as Shigella dysenteriae to survive for 5 or 6 days in or outside the body of Chrysomyia megacephala. However, he did not find E. typhosa associated with flies of this species which he caught in Peiping.

Morischila and Tsuchimochi (Riley and Johannsen, 1932) found that $\underline{E}$. typhosa passed through the cockroach intestine apparently unharmed. In 1922 Macfie (Riley and Johannsen, 1932) got negative results.

Darling (Wheeler, 1914) performed a series of experiments to determine whether ants carmy $\underline{E}$. typhosa on the 
surfaces of their bodies or in their intestinal tract with negative results. He concluded that the formation of formic acids killed and inhibited the bacteria. Wheeler (1914) thinks this was an erroneous conclusion, and that it is very likely that ants, because of their habits, do spread pathogenic bacteria.

The possible germicidal action of the gastro-intestinal secretions of the yellow fever mosquito (Aedes aegypti) on E. typhosa and Serratia marcescens was found to be negative by St. John, Simmons, and Reynolds (1930).

A complete description of Eberthella typhosa may be found in Bergey's Manual (1939, 5th ed., page 463).

Chow, C. Y. 1940 The common blue-bottle fly, Chrysomyia megacephala, as a carrier of pathogenic bacteria in Peiping, China. Chinese M. J., 57, 143-153. Faichnie, N. 1.909a Fly-borne enteric fever; the source of infection. J. Roy. . Army Med. Corps, 13, 580-584. Faichnie, N. 1909b Bacillus typhosus in flies. J. Roy. Army Med. Corps, 13, 672.

Ficker, M. 1903 Typhus und Fliegen. Arch. f. Hyg., 46, $274-283$.

Graham-Smith, G. S. 1913 Flies in relation to disease. 292 pp. Cambridge University Press, Cambridge.

Hamilton, A. 1903 The fly as a carrier of typhoid; an inquiry into the part played by the common house fly in the recent epidemic of typhoid fever in Chicago. J. Amer. Med. Assoc., 40, 576-583.

Howard, L. 0. 1911 The house fly; disease carrier. 2d ed., 312 pp. Frederick A. Stokes Company, New York.

Riley, W. A. and Johannsen, O. A. 1932 Medical Entomology. Ist Ed., 476 pp. McGraw-Hill Book Co., New York. (See p. 121.)

St. John, J. H., Simmons, J. S., Reynolds, F. H. K. 1930 The survival of various microorganisms within the gastro-intestinal tract of Aedes aegypti. Amer. J. Trop. Med., 10, 237-241.

Wheeler, $\bar{W}$. M. 1914 Ants and bees as carriers of pathogenic organisms. Am. J. Trop. Med. and Prev. Med., ㅌ, 160 .

Genus: Salmonella

SALMONELLA CHOLERAESUIS WeIdin

(See Bacillus cholerae suis.)

Insect concorned: The honey bee, Apis mellifera. 
In 1906 White isolated Bacillus cholerae suis from the intestine of the honey bee. Very probably this is the same organism which is now known by the name Salmonella choleraesuis (Bergey's Manual, 1939, 5th ed., p. 440.)

White, G. F. 1906 The bacteria of the apiary with special reference to bee diseases. U. S. Dept. Agr., Bur. Entomol., Tech. Bull. No. 14, 50 pp.

\section{SALMONELLA ENTERITIDIS (Gaertner) Castellani and Chalmers \\ (See also Danysz bacillus.)}

Insect concerned: Louse.

Huang, Chang, and Lieu (1937), during their studies on 17 cases of systemic infection of Salmonella enteritidis not associated with food poisoning, found that finely ground lice from their patients gave a growth of Salmonella enteritidis when cultured on nutrient media.

Huang, C. H., Chang, H. C., and Lieu, V. T. 1937 Salmonella infection. A study of 17 cases of $\underline{\text { S. enteritidis }}$ septicemia. Chinese Med. J., 52, 345-366.

SALMONELLA PARATYPHI (Kayser) Bergey et al.

(See Bacterium paratyphi.)

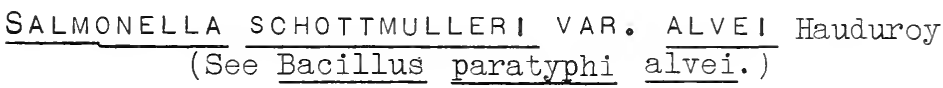

Genus: Shigella

SHIGELLA DYSENTERIAE (Shiga) Castellani and Chalmers

Insect concerned: The blue-bottle fly, Chrysomyia megacephala.

Chow (1940) found that 8 per cent of the blue bottle flies (Chrysomyia megacephala) caught by him in Peiping harbored Shigella dysenteriae. Experimentally both Shigella dysenteriae and Eberthella typhosa survived in or outside the fly's body for 5 to 6 days. 
Chow, C. Y. 1940 The common blue-bottle fly, Chrysomyia megacephala, as a carrier of pathogenic bacteria in Peiping, China. Chinese M. J., 57, 143-153.

\section{Tribe: SERRATEAE}

Genus: Serratia

\section{SERRATIA FUCHSINA (Boekhaus and DeVries) Bergey et al. \\ (See Bacillus fuchsinus.)}

\section{SERRATIA MARCESCENS Bizio (See Bacillus prodigiosus.)}

Insects concerned: The silkworm, Bombyx mori; Pseudococcus citri; the bee moth, Galleria mellonella; the corn borer, Pyrausta nubilalis; the gypsy moth, Porthetria (Lymantria) dispar; Schistocerca gregaria; Tenebrio molitor; the roach, probably Periplaneta orientalis; the termite, Zootermopsis angusticollis; the mosquito, Aedes aegypti; the milkweed bug, Oncopeltus fasciatus; the house fly, Musca domestica; the stable-fly, Stomoxys calcitrans; and the Rocky Mountain wood tick, Dermacentor andersoni.

The history of the associations between insects and Serratia marcescens is very interesting. In stating it briefly we quote from DeBach and Mcomie (1939):

"Masera (1936a) in a comprehensive treatment of the subject states that as early as 1817 Rozier noticed a red coloration forming in the dead bodies of silkworms. This was again noticed by Pollini and Vasco in 1819, Re and Ascolese in 1837, etc. However, the credit for the actual isolation in 1886 of Bacillus prodigiosus from a silkworm larvae is due to Perroncito. Bandelli about the same time isolated Bacillus prodigiosus from the exterior of silkworms (Bombyx mori) and later stated that the red pigment did not appear until after the death of the larvae.

"Metalnikov (1930) isolated a red-pigment former like Bacillus prodigiosus from the larvae of the gypsy moth, Lymantria dispar (L.) which was very virulent. [Earlier (1920) this worker found the bee moth, Galleria mellonella, to offer no resistance to this bacterium, dying from very small doses.] 
"Zernhoff (1931) has reported that this bacillus is very virulent to the larvae of the wax moth, Galleria mellonella (L.), by inoculation but not by ingestion, whereas both methods result in infection in the larvae of the European corn borer, Pyrausta nubilalis (Hon.).

"Masera has recently (1934a and b, 1936a, b, and c) published an extensive series of papers dealing with experimental studies of the pathogenicity of Bacillus prodigiosus. He found it to be fatal to $\overline{\text { Pyrausta }}$ nubilalis by inoculation and by ingestion; while to Bombyx mori fatal when inoculated but not necessarily fatal when ingested, depending particularly on the age of the larvae. In the case of Galleria mellonella he found it to be fatal only by inoculation, never by ingestion, and finally he found it to be nonpathogenic to the larvae of Tenebrio molitor L. [According to Masera, the immunity of the insects may be due to their food which normally contains microorganisms.]

"Lepseme (1937a, 1937b) has reported the occurrence of an epizootic in laboratory-bred Schistocerca gregaria Forsk. caused by Bacillus prodigiosus and has shown that inoculation produces death in one or two days with the usual red coloration occurring (in this case mainly in the abdomen) while ingestion produces death only occasionally." [This worker (1938) also found it to be a secondary invader to the infestation of the fungus Aspergillus flavus in Schistocerca gregaria.]

De Bach and McOmie (1939) found their laboratory stock of the termite, Zootermopsis angusticollis, to be suffering from two bacterial diseases. One of these diseases was due to Bacterium sp. (which see); the other to Serratia mareescens. The latter organism causes the head and appendages of the dead termites to turn red.

Longfellow (1913) was able to cultivate Bacillus prodigiosus from the feces of the common houseroach. Duncan (1926) found "B. prodigiosus" several times in the gut contents of the stomoxys calcitrans. Pospelov (1936) isolated Bacterium prodigiosum from Pseudococcus citri and found it to be virulent for several species of the Pseudococcus.

In 1927, Dr. Breed (1940) received 32 cultures of Serratia marcescens from Professor E. Hiratsuka, Japan, which had been isolated from silkworm larvae and cocoons. Metalnikov and Chorine (1928) found that an organism which 
Tateiwa had isolated from silkworms with "flacherie" and had called Bacterium prodigiosus (probably prodigiosum)

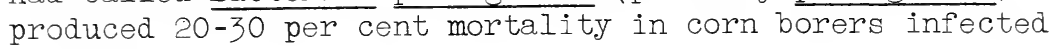
by mouth.

The writer (Steinhaus, 1939) attempted to establish Serratia marcescens as part of the bacterial flora in the gut of the milkweed bug, oncopeltus fasciatus, by experimental feedings but was unsuccessful. Later (1941), he used this bacterium to demonstrate that the tick, Dermacentor andersoni, could acquire bacteria from the skins of experimental animals and pass these bacteria from larvae to adults.

The possible germicidal action of the gastrointestinal secretions of the yellow-fever mosquito, Aedes aegypti, on Serratia marcescens was found to be negative by St. John, Simmons, and Reynolds (1930). It was further found that this bacterium, as well as others, survived for at least 24 hours in the gut of the mosquito but that it could not be demonstrated after an interval of seven or more days.

For a complete description of Serratia marcescens, see Bergey Manual ( 5 th ed., p. 422).

Breed, R. S. 1940 Personal communication.

DeBach, P. H., and Mcomie, W. A. 1939 New diseases of termites caused by bacteria. Ann. Entomol. Soc. Amer., 32, $137-146$.

incan, J. T. 1926 On a bactericidal principle present in the alimentary canal of insects and arachnids.

Parasitol., 18, 238-252.

Lepseme, P. $1 \overline{93} 7 \mathrm{a}$ Sur la présence du Bacillus prodigiosus chez le criquet pélerin (Schistocerca gregaria Forsk.) Bul1. Soc. Hist. Afr. N., 28, 406-411.

Lepseme, P. $1937 \mathrm{~b}$ Action de Bacillus prodigiosus et

Bacillus pyocyaneus sur le Criquet pélerin (Schistocerca gregaria Forsk.). Compt. rend. soc. biol., $125,492-494$. Lepseme, P. 1938 Recherches sur une aspergillose des acridiens. Bull. Soc. Hist. Nat. Afr. N., 29, 372-334. Longfellow, R. C. 1913 The common house roach as a

carrier of disease. Am. J. Public Health. 3, 58-61. Masera, E. 1934 a II Bacterium prodigiosum L. et $N$. nella patologia del baco da seta. R. Staz. Bacologia Sper.

ai Padova. Ann., 47, 90-98. Masera, E. 1934 b' II Bacillus prodigiosus nella patologia del baco da seta. R. Staz. Bacologica Sper. di Padova. Ann., $47,99-102$.

Masera, E. 1936 a Il Bacillus prodigiosus Flligge nella patologia del baco da seta e degli insetti. R. Staz. Bacologia Sper. di Padova. Ann., 48, 409-416. 
Masera, E. $1936 b$ Compartemente del Bombyx mori L. alla infezione sperimentale del Bacterium prodigiosum et. N. R. Staz. Bacologica Sper. di Padova. Ann., 48, $417-422$.

Masera, E. 1936c Fenomeni de antagonismo et antibiosi fra Bacillus prodigiosus Fllgge e Beauveria bassiana Vuill. R. Staz. Bacologica Sper. di Padova. Ann., 48, $423-458$.

Metalnikov, S. 1920 Immunité de la chenille contre divers microbes. Compt. rend. soc. biol., 83, 119-121.

Metalnikov, S. and Chorine, V. 1928 The infectious diseases of Pyrausta nubilalis Hb. Internat. Corn Borer Invest., Sci. Repts. 1 , 46-49.

Pospelov, V. P. 1936 summary of the scientilic research work of the institute of plant protection for the year 1935. 'In Russian. Roy. 8 vol., 596 pp. Ienin Acad. Agri. Sci., pp. 318-321.

Steinhaus, E. A. 1939 and 1941. In press.

St. John, J. H., Simons, .J. S., and Reynolds, F. H. K. 1930 The survival of various microorganisms within the gastrointestinal tract of Aedes aegroti. Am. J. Trop. Med., 10, 237-241.

Zernoff, $\bar{V}$. 1931 Microbes virulents pour les chenilles (Galleria mellonella et Pyrausta nubilalis). Compt. rend. soc. biol., 106, 54 $45-546$.

\section{SERRATIA PLYMOUTHENSIS (Migula) Bergey et al.}

Insect concerned: The cricket, Neombius fasciatus, var. fasciatus.

The growth of Serratia plymouthensis is characterized by a bright red pigment similar to Serratia marcescens, but is a visible gas producing type. (See Bergey's Manual, 1939, 5th ed., page 425, for a description of Serratia plymouthensis.)

This bacterium was found by Steinhaus (1941) to occur in the alimentary canal of nearly every specimen of the above-named cricket which he examined. The crickets were collected in nature in a meadow near Columbus, Ohio.

Steinhaus, E. A. 1941 A study of bacteria associated with thirty species of insects. J. Bact., 42, 757-790. 
Family: LACTOBACTER I ACEAE

Tribe: StREPTOCOCCEAE

Genus: Diplococcus

\section{DIPLOCOCCUS BOMBYCIS Paillot}

Insects concerned: The silkworm, Bombyx mori; Euproctis chrysorrhoea; the gypsy moth, Porthetria (Lymantria) dispar; Eriogaster lanestris; and Vanessa urticae.

Paillot isolated a coccobacillus, which he called Diplococcus bombycis, from the silkworm. He states (1933) that in this coccobacillus there are constantly present transverse, double bands of "chromatophiles." Both the larvae of Porthetria dispar and Euproctis chrysorrhoea were found to be very resistant to infection with the organism, while the larvae of $\underline{\mathrm{E}}$. lanestris and Vanessa urticae were easily infected.

Paillot, A. 1933 L'infection chez les insectes, 535 pp. Imprimerie de Trevoux, Paris. (See pp. 158, 182, and 303.)

\section{DIPLOCOCCUS LIPARIS Paillot}

Insect concerned: The gypsy moth, Porthetria (Iymantria) dispar.

Diplococcus liparis was isolated by Paillot (1917) from larvae of the gypsy moth. This organism appeared to be of little pathogenic importance.

* Paillot, A. 1917 Microbes nouveaux parasites des

chenilles de Lymantria dispar. Compt. rend. hebdom.

Séances acad. sci., 164, 525-527.

paillot, A. 1933 L'infection chez les insectes. 535 pp.,

Imprimerie de Trevoux, Paris. (See 299-300.)

DIPLOCOCCUS LYMANTRIAE Paillot

(See Bacillus lymantriae and Coccobaicillus lymantriae.)

Insect concerned: The gypsy moth, Porthetria (Iymantria) dispar. 
Due to the confusion in the literature, it has been rather difficult to determine whether Diplococcus lymantriae, Bacillus lymantriae, and Coccobacillus lymantriae are the same organism. It appears likely, however, that Diplococcus lymantriae is distinct since Paillot (1917) states: "The microbes parasitic in the larvae of Porthetria (Lymantria) dispar here described are a coccobacillus provisionally identified as Bacillus lymantria, Diplococcus lymantria, sp. n., which is only slightly pathogenic to the caterpillars, and Bacillus liparis sp. n." One might assume that perhaps Coccobacillus lymantriae and Bacillus lymantriae are the same, Picard and Blanc using the generic name Coccobacillus, and Paillot, the generic name Bacillus. Paillot (1933) also refers to a "Bacillus (Bacterium) iymantriae."

* Paillot, A. 1917 Microbes nouveaux parasites des chenilles de Lymantria dispar. Compt. rend. hebdom. acad. sci., $164,525-527$.

Paillot, A. $1 \overline{933}$ L'infection chez les insectes. 535 pp. Imprimerie de Trevoux, Paris. (See p. 131.)

\section{DIPLOCOCCUS MELOLONTHAE Paillot}

Insects concerned: The cockchafer, Melolontha melolontha; Vanessa urticae; the gypsy moth, Porthetria (Iymantria) dispar.

Paillot (1917) found that a coccobacillus and Diplococcus melolonthae killed cockchafers in 24 hours, while the diplococcus alone was only slightly pathogenic. Paillot (1933) mentions Diplococcus melolonthae as an example of bacterial variation.

* Paillot, A. 1917 Microbes nouveaux, Parasites du Hanneton. Action pathogene sur Chenilles de Vanessa urticae, Lymantria dispar, et sur Vers a Goie. Compt. rend. soc.

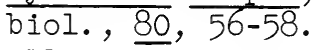

Paillot, $\bar{A} .1933$ L'infection chez les insectes. 535 pp. Imprimerie de Trevoux, Paris. (See p. 139.)

\section{DIPLOCOCCUS PEMPHIGOCONTAGIOSUS}

Inșect concerned: Lice.

Wardle (1939) refers to the transmission of Diplococcus pemphigocontagiosus by lice. (See also MacGregor, 1917.) 
MacGregor, M. E. 1917 A summary of our knowledge of insect vectors of disease. Bull. Entomol. Res., $\underline{8}$, $155-163$.

Wardle, R. A. 1929 The problems of applied entomology, 588 pp. Manchester University Press, England. (See p. 106.)

\section{DIPLOCOCCUS PIERIS Paillot}

Insect concerned: The cabbage butterfly, Pieris brassicae.

Paillot (1919) isolated Diplococcus pieris from larvae of diseased white cabbage butterflies. From the same source, he isolated 8 other bacteria. (See Bacillus pieris fluorescens.) He considered these bacteria to be secondary invaders, the primary invader, Apanteles glomeratus, a parasitic wasp, being the predisposing factor in the bacterial infection of the white cabbage butterfly.

Paillot, A. 1919 Coccobacilles parasites des chenilles de Pieris brassicae. Compt. rend. acad. sci., 168, $476-478$.

Paillot, A. 1924 Sur une nouvelle maladie des chenilles de Pieris brassicae et sur les maladies du noyau chez les insectes. Compt. rend. acad. sci., 179, 1353.

\section{$\frac{\text { DIPLOCOCCUS }}{\text { (See Bacillus pluton.) }}$ Bet}

Insect concerned: Honey bee, Apis mellifera.

In the second edition of Bergey's Manual (1925, p. 45) the name Diplococcus pluton was used for Bacillus pluton (which see).

Genus: Streptococcus

STREPTOCOCCUS AGALACTIAE Lehmann and Neumann

Insects concerned: The house fly, Musca domestica; and Hippelates flies.

Saunders (1940a, b) concludes that the house fly and Hippelates flies serve as vectors of bovine mastitis. 
Since this worker failed to definitely state name of the microorganism concerned in his experiments, it is assumed he refers chiefly to Streptococcus agalactiae.

Saunders, D. A. 1940a Musca domestica, a vector of bovine mastitis (preliminary report). J. Amer. Vet. Med. Assoc., 97, 120-123.

Saunders, D. A. $1940 \mathrm{~b}$ Hippelates flies as vectors of bovine mastitis (preliminary report). J. Amer. Vet. Med. Assoc., 97, 306-308.

\section{STREPTOCOCCUS APIS MaASSEn}

(See also Bacillus alvei, Bacillus pluton, and Bacterium eurydice, and Streptococcus liquefaciens.)

Insect concerned: The honey bee, Apis mellifera.

Maassen (1908) believed that the etiology of European foulbrood is not uniform but that the disease is caused chiefly by Streptococcus apis and Bacillus alvei. Maassen (1908, 1913) stated that the disease could not be experimentally produced by pure cultures of these organisms.

When bees were fed on triturated sick or dead larvae mixed with honey, they became sick with a mild form of foulbrood from which they ultimately recovered. Numerous attempts by other workers to produce European foulbrood by inoculation with pure cultures of Streptococcus apis have been largely unsuccessful.

Concerning this organism, Burnside (1934) states: "There seems to be insufficient reason for assuming that the lancet-shaped bacterial cell, B. pluton, found in late stages of infection in European foulbrood, is of different genus and species from the similar form Streptococcus apis, which is readily obtained in culture from sick larvae.

"The identity of Streptococcus apis and Bacillus pluton is suggested by morphological similarity . . ." Burnside goes on to suggest that Bacillus pluton and Streptococcus apis are variants, or stages in the life history of Bacillus alvei.

Bergey's Manual (1939, 5th ed., page 339) lists Streptococcus apis as a synonym for Streptococcus liquefaciens. This is done on the basis of the work of Hucker (1932) who found these two gelatin-liquefying streptococci to be culturally similar. 
Burnside, C. E. 1934 Studies on the bacteria associated with European foulbrood. J. Econ. Entomol., 27, 656668.

Hucker, G. J. 1932 Studies on the Coccaceae. XVII. Agglutination as a means of differentiating the species of Streptococcus and Leuconastoc. N. Y. State Agric. Expt. Station, Tech. Bull. No. 190, page 17.

* Maassen, A. 1908 Zur Atiologie der sogenannten Faulbrut der Honigbienen. Arbeiten K. Biol. Anst. Land u. Forstev., 6, 53-70.

Maassen, $\bar{A}$. 1913 Weitere Mitteilungen Uber die seuchenhaften Brutkrank heiten der Bienen insbesondere ther die Faulbrut. Mitt. aus der Kaiserl. Biolog. Anstalt fflr Land--u. Forstev. 8th Ann. Rept. Pt. 14, pp. 48-58.

\section{STREPTOCOCCUS BOMBYCIS Sirtirana and Paccanaro} (See also streptococcus pastorianus.)

Insect concerned: The silkworm, Bombyx mori.

Silkworms are susceptible to infection by several pathogenic bacteria. One of the worst of these plagues of sericulture is caused by Streptococcus bombycis (Sartirana and Paccanaro, 1906), ann is frequently known as "flacherie of the silkworm." This Eram-positive coccus forms chains from 5 to 12 microns long, and is a facultative anaeroje.

According to Wardle (1929), Paillot states that the term "flacherie" represents a group of three distinct maladies, one of which appears to be associated with Streptococcus bombycis. These are:

(1) A disorder associated with an abnormal abundance, in the intestine of the silkworm, of a sporulating bacillus morphologically identical with that described by Pasteur (see Bacillus bombycis.)

(2) An acute form of "flacherie" or "flacherie typique" associated apparently 'with a filterable virus.

(3) A chronic type of "flacherie," the "gattine" of French workers, and "macilenze" of Italian workers, probably associated with Streptococcus bombycis.

In the last-mentioned disease, there is generally a swelling of the anterior body wall, which becomes more or less translucent. An organism, apparently Streptococcus bombycis, was isolated from the intestinal contents. (See Paillot, 1926.) 
According to Paillot (1928) Streptococcus pastorianus (which see) is synonymous with streptococcus bombycis.

Paillot (1928) gives a complete description of Streptococcus bombycis and Bergey's Manual lists it. (5th ed., p. 353.)

Paillot, A. 1926 Sur l'étiologie et l'épidémiologie de la gattine du Ver a soie ou "maladie des tetes claires." Compt. rend. acad. sci., 183, 251. Paillot, A. 1928 Les maladies du Ver a Soie, Grasserie et dysenteries. $328 \mathrm{pp}$. Editions du Service Photographique, de I'Université, Lyon. (See pages 171-172; 195-198. )

* Sartirana, S., and Paccanaro, A. 1906 Cent. f. Bakt., I abt., Orig., 40, 331.

Wardle, R. A. $19 \overline{29}$ The problems of applied entomology 587 pp. Manchester Univ. Press, England. (See page 101.

\section{STREPTOCOCCUS DISPARIS Glaser}

Insects concerned: The Japanese race of the gypsy moth, Porthetria (Lymantria) dispar; the silkworm, Bombyx mori; and the army worm, Cirphis unipuncta.

In 1918, Glaser described an infectious disease of caterpillars of the Japanese race of the gypsy moth which spread to cultures of the American race. It is clinically, pathologically, and etiologically distinct from wilt (a filterable vimus disease). A streptococcus, which Glaser named Streptococcus disparis, was found to be the cause of the disease.

The streptococcus is ingested with contaminated food. During the latter stages of the disease and after death it invades practically all the tissues. The symptoms are diarrhoea, loss of appetite and of muscular cobrdination. The skin of the dead insect does not rupture as in the case of wilt, though the larva hangs in a faccid condition by its prolegs, and does have the appearance of a caterpillar dead from wilt.

Streptococcus disparis is a gram positive, non-motile, encapsulated organism with a diameter of less than one micron.

Successful field experiments were conducted with Streptococcus disparis in sections of the gypsy mothinfected territory in the United States. In two places severe epizootics were produced. The organism is not pathogenic to silkworms (Bombyx mori) nor to the army worm 
(Cirphis unipuncta). It is not pathogenic to human beings, guinea pigs, or rabbits. The organism is listed in Bergey's Manual (5th ed., p. 354 ).

Glaser, R. W. 1918 A new disease of gypsy-moth caterpillars. J. Agric. Research, 13, 515-522.

\section{STREPTOCOCCUS FAECALIS Andrews and Horder}

Insects concerned: The German roach, Blattella germanica; and the web-worm, Hyhantria cunea, the milkweed bug, Oncopeltus fasciatus; the bagworm, Thyridopteryx ephemeraeformis; the cicada, Tibicen linnei.

This streptococcus was isolated by Steinhaus (1941) from the alimentary tracts of the German roach, web-worm, and the milkweed bug. In this last insect the strain was somewhat atypical. See Bergey's Manual, 5th ed., p. 337 , for a complete description. (See also the work of Duncan, 1926.)

Duncan, J. T. 1926 On a bactericidal principle present in the alimentary canal of insects and arachnids. Parasitol., 18, 238-252.

Steinhaus, E. A. 1941 A study of the bacteria associated with thirty species of insects. J. Bact., 42, 757-790.

STREPTOCOCCUS HAEMOLYTICUS ROIIY

(See Streptococcus pyogenes.)

STREPTOCOCCUS LIQUEFACIENS (Sternberg) Orla-Jensen (See Streptococcus apis.)

Insect concerned: The honey bee, Apis mellifera.

Bergey's Manual (1939, 5th ed., page 339) lists Streptococcus apis as a synonym for streptococcus liquefaciens. Hucker (1932) found these two gelatinliquefying streptococci to be culturally almost identical.

Streptococcus apis has been associated with European foulbrood of bees.

Hucker, G. J. 1932 Studies on the coccaceae. XVII. - Agglutination as a means of differentiating the species of Streptococcus and Leuconontoc. N. Y. State Agric. Expt. Station, Tech. Bull. No. 190, p. 17. 


\section{STREPTOCOCCUS DASTORIANUS KrassilstschiK}

(See Streptococcus bombycis.)

Insect concerned: The silkworm, Bombyx mori.

This organism was isolated in 1896 by Krassilstschik. Pailiot (1923) susfests that streptococcus pastorianus maj De the same as Streptococcus bombycis. Bergey's Manual (5th ed., p. 357) lists both of these organisms.

* Krassilstschik, I. IO96 Compt. rend. acad. Sc..., 427. Paillot, A. 1928 Les malidies au Ver a Soie, Grasserie

et dysenteries. $328 \mathrm{pp}$. Editions du Service Photographique de I'Université, Lyon. (See pases 171-172.)

\section{STREPTOCOCCUS PITYOCAMPAE ALPHA DUTPENOY}

Insect concerned: The processionary moth caterpillar, Cnethocampa pityocampa.

Dufrenoy (1919) found that three organisms attacked the processionary moth caterpillar: Bacterium oityocampae, Streptococcus pityocampae alpha, and Streptococcus pityocampae beta. When the caterpillars are inoculated with Stroptococcus pityocampae alpha, they die in two to four deys, the muscles being infiltrated with the coccus and the Iibers degenerating and losing their striation.

Paillot (1933) states that he is surprised that the beta strain of this organism was given the same generic name as the alpha strain since the beta strain is gram negative. Furthermore, Paillot indicates that the alpha type is ill-placed in the Streptococcus genus because the alpha strain is motile.

* Dufrenoy, J. 1919 Les formes de dégénérescence des chenilles de Cnethocampa pityocampa parasitees. Compt. rend. soc. biol., $82,288-289$.

Paillot, A. 1933 I'Infection chez des insectes. 535 pp.

Imprimerie de Trevoux, Paris. (See pp. 125-126.)

STREPTOCOCCUS PITYOCAMPAE BETA Dufrenoy (See Streptococcus pityocampae alpha.)

\section{STREPTOCOCCUS PYOGENES ROsenbach}

Ticks concerned: Argas persicus; Ornithodoros moubata. 
Duncan (1926) found Streptococcus haemolyticus (now known as Streptocozcus pyogenes) to be inhibited by the bactericidal principle of the gut contents of Argas persicus but not by that of ornithodoros moubata.

Duncan, J. T. 1926 on a bactericidal principle present in the alimentary canal of insects and arachnids. Parasitol., 18, 238-252.

Family: MICROCOCCACEAE

Genus: Micrococcus

$\frac{\text { MICROCOCCUS }}{\text { (See Staphylococcus acridicida.) }}$

$\frac{\text { MICROCOCCUS }}{\text { (See EMWinia }} \frac{\text { AmYLOVORUS }}{\text { amylova.) }}$

MICROCOCCUS C. White

Insect concerned: The honey bee, Apis mellifera.

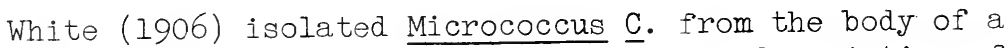
healthy honey bee. He has given a complete description of this organism.

White, G. F. 1906 The bacteria of the apiary with special reference to bee diseases. U. S. Dept. Agr., Bur. Entomol., Tech. Bull., No. 14, 50 pp.

\section{MICROCOCCUS CATARRHALIS Frosch and Kolle \\ (See Neisseria catarrhalis.)}

\section{MICROCOCCUS CHERSONESIA COrbet}

Insect concerned: An unidentified long-horned grasshopper of the family Tettigonidae.

During studies on the bacterial flora of normal insects, Steinhaus (1941) isolated a gram-positive coccus from a long-horned grasshopper. The coccus at times appeared almost as a very short rod. This characteristic is shared by an organism which Bergey's Manual (1939, 5th ed., page 258) describes under the name Micrococcus chersonesia, 
isolated from the latex of a rubber tree. The growth of this organism is described as being "dull" whereas that of the coccus isolated from the grasshopper is glistening. otherwise the physiologic, morphologic and cultural characteristics of the two organisms agree fairly well.

Steinhaus, E. A. 1941 The study of the bacteria associated with thirty species of insects. J. Bact., 느, 757-790.

\section{MICROCOCCUS CONGLOMERATUS Migula}

Insect concerned: The bedbug, Cimex lectularius L.

An organism similar to Micrococcus conglomeratus was isolated from the bedbug by Steinhaus (1941).

Steinhaus, E. A. 1941 A study of the bacteria associated with thirty species of insects. J. Bact., 42, 757-790.

\section{MICROCOCCUS CURTISSI Chorine}

Insects concerned: The corn borer, Pyrausta nubilalis; the flour moth, Ephestia klhniella; the bee moth, Galleria mellonella.

In July, 1928, Chorine (1929) observed a very high mortality among the young corn borer larvae due to an organism which he called Micrococcus curtissi. The organism also proved to be very virulent towards full grown borers when injected, and to a less extent by mouth. By injection it was virulent toward the larvae of Ephestia klthniella, though the larvae of Galleria mellonella proved to be more resistant.

A complete description of the organism has been given by Chorine (1929).

*Chorine, V. 1929 New bacteria pathogenic to the larvae of Pyrausta nubilalis $\mathrm{Hb}$. Internat. Corn Borer Invest., Sci. Rpts., 2 , 39-53.

\section{MICROCOCCUS EPHESTRIAE}

Insect concerned: The flour moth, Ephestia klthniella. 
According to Mattes (1927), Micrococcus ephestriae is apparently a nonpathogenic irhabitant of the intestinal tract of the flour moth larvae. It is an encapsulated organism.

* Mattes, 0. 1927 Parasitare Krankheiten der Mehlmattenlarven und Versuche Hber ibre Verivendbarkeit als biologisches Bekämpfrengsmittel. Sitzungsberichte der Gesellschaft zur Beflrderung der gesamten Naturuvissenschaften zu Marburg, 62, 381-417.

\section{MICROCOCCUS EPIDERMIDIS (Kligler) Hucker}

Insect concerned: Grylloblatta campodeiformis campodeiformis.

Burroughs (1941) isolated 3 strains of this coccus from the alimentary tract of the above grylloblattid. (See Bergey's Manual, 5th edition, p. 255, for complete description of this coccus.)

Burroughs, A. L. 1941 Bacterial flora of the alimentary tract of Grylloblatta campodeiformis campodeiformis Walker. Montana State College, Master's Thesis. $47 \mathrm{pp}$.

\section{$\frac{\text { MICROCOCCUS }}{\text { (See also Gyrococcus flaccidifex. }} \frac{\text { FLCCIDIFEX }}{\text { DANA I Brown }}$}

Insect concerned: The monarch butterfly, Danais archippus.

Brown (1927) considered this organism to be the cause of "wilt" disease in monarch butterfly larvae. Smears showed the body fluid teaming with "motile cocci." Brown states, "One cannot be certain from the meager cultural details given by Glaser and Chapman (1912) of (Gyrococcus) flaccidifex whether the present organism is specifically distinct. On account of its pathological effect it seems to be closely related to flaccidifex and $I$ am naming it as a new subspecies. I failed to find any undue gyrating of the cocci in the hanging drop upon which they erect their genus Gyrococcus."

A complete description of the organism has been given by Brown (1927).

* Brown, F. M. 1927 Descriptions of new bacteria found in insects. Am. Mus. Novitates, Number 251, 11 pp. 
Glaser, R. W. and Chapman, J. W. 1912 Studies on the wilt disease or "flacherie" of the gypsy moth. Science, $\underline{36}, 219-224$.

\section{MICROCOCCUS FLAVUS Lehmann and Neumann}

Insect concerned: The housefly, Musca domestica.

Micrococcus flavus, an air and milk organism, was isolated by Torrey (1912) from the intestinal content, as well as the body surface, of flies.

Bergey's Manual, 5th edition, 1939, p. 247, gives a complete description of the organism.

Torrey, J. C. 1912 Jour. Infect. Diseases, 10, 169-176.

\section{MICROCOCCUS FREUDENREICHII Guillebeau}

Insect concerned: The bag-worm; Thyridopteryx ephemeraeformis; Grylloblatta campodeiformis campodeiformis Walker.

Steinhaus (1941) found Micrococcus freudenreichii to be part of the bacterial flora of the alimentary canal of the larva of the bag worm moth. Burroughs (1941) isolated a etrain of this micrococcus from the alimentary tract of a grylloblattid. A description of this organism may be found in Bergey's Manual (1939, 5th ed., page 253).

Burroughs, A. I. 1941 Bacterial flors of the alimentary tract of Grylloblatta campodeiformis campodeiformis Walker. Montana State College Master's Thesis, $47 \mathrm{pp}$. Steinhaus, E. A. 1941 A study of the bacteria associated with thirty species of insects. J. Bact., 42, 757-790.

\section{MICROCOCCUS INSECTORUM Burrill (See Bacilius insectorum.)}

Insect concerned: Chinch bug, Blissus leucopterus.

Forbes (1882) found a micrococcus in the chinch bug which occurred primarily in the cecal organs. He concluded they were normal to these organs, being exceedingly abundant in all those examined Burrill (1883) subsequently made a technical study of this organism and gave the organism the name Micrococcus insectorum. 
Smith (1933, p. 54) refers to "Bacillus insectorum Burrell [Burrill] (Forbes, 1895)" as a cause of a bacterial disease of the chinch bug. Later (p. 59) he refers to Micrococcus insectorum Burrill as being similar to organisms that cause the silk-worm diseases. He probably means the same organism.

Burrill, T. J. 1883 New species of micrococcus. Am. Nat., $17,319$.

* Forbes, S. A. 1882 Bacterium a parasite of the chinch bug. Am. Nat., 16, 824-825.

Smith, R. C. 1933 Fungus and bacterial diseases in the control of grasshoppers and chinch bugs. 28th biennial Rpt. Kan. St. Bd. Agri., 44-58.

\section{MICROCOCCUS LARDARIUS Krassilstschik}

Insect concerned: Silkworm, Bombyx mori.

Krassilstschik (1896) found this organism in the intestine and body cavity of silkworms and thought it to be the cause of grasserie. He showed that the organism was distinctly different from Streptococcus bombycis.

Krassilstschik, M. J. 1896 Sur les parasites des Vers a sole sains et malades. Contribution a l'etude de la flacherie, de la grasserie et de la pebrine. (Communication preliminaire). Memoires soc. zoo. de France., 2, 513-522.

\section{MICROCOCCUS MAJOR}

Insects concermed: Nun moth, Lymantria monacha; and Hyponomenta sp.

Eckstein (1894) in working with bacteria associated with nun moth larvae, isolated Micrococcus major. He found it pathogenic also for Hyponomenta species.

Eckstein, K. 1894 Untersuchungen ther die in Raupen vonkommenden Bakterien. Z. F. Forst- und Jagdwesen, 26, 3-20, 228-241, 285-298, 413-424. 
In 1922, Paillot (1924) isolated this bacterium from diseased Neurotoma nemoralis larvae, but he did not find it of any great help in checking the insect in nature. $\mathrm{He}$ (1933) mentions the pathogenicity of the organism to Agrotis segetum and Agrotis pronubana.

If the organism is gram-negative, as Paillot suggests, it should be placed in the genus Neisseria.

* Paillot, A. 1924 Sur deux bacteries parasites des

larvae de Neurotoma nemoralis. Compt. rend. hebdom. acad. sci., 178, 246-249.

Paillot, A. $1 \overline{933}$ L'infection chez les insects. 535 pp.

Imprimerie De Trevoux, Paris. (See p. 310).

\section{MICROCOCCUS NIGROFACIENS Northrup}

Insects concerned: Phyllophaga (Lachnosterna) spp.;

Allorrhina spp.; American cockroach, Periplaneta americana; green June beetle, Allorrhina (Cotinis) nitida; Malacosoma americana; cockchafer, Melolontha melolontha; the rhinoceros beetle, Strategus utanus; May-beetle, Phyllophaga (Lachnosterna) vandinei.

In 1914, Northrup (1914a) described a bacterial disease of June beetle larvae, Lachnosterna spp., caused by Micrococcus nigrofaciens. She found that this micrococcus was always accompanied by a putrefactive organism, which she regarded as probably being Baclllus septicus insectorum Krassilstschik. Northrup concluded from her observations that the organisms exist in the soil and that the diseased larvae become infected through surface injury since experiments on the infection of soils showed that excessive moisture in the soil greatly favored the spread of the micrococcus. The common cockroach, Periplaneta americana, was also found to be attacked by the micrococcus, but the infection apparently limited itself to the legs. She gave morphological and cultural characteristics of the organism (1914, b).

Smyth (1917, 1920) reported a high mortality among the grubs of May-beetles and of the rhinoceros beetles in experimental boxes due to Micrococcus nigrofaciens. Du Porte (1915) reported it pathogenic for Malacosoma americana, and Davis and Luginbill (1921), for the green June beetle.

Davis, J. J. and Luginbill, P. 1921 The green June beetle or Fig-eater. North Carolina Agr. Expt. St. Bull. 242,

$35 \mathrm{pp}$. 
Du Porte, E. M. 1915 Two bacterial diseases of injurious insect larvae. 7th Ann. Rept. Quebec Soc. Prot. Plants from Insects and Fung. dis. (1914-1915). Quebec, 81-85. Northrup, Zae. 1914a A bacterial disease of the June beetles, Lachnosterna. Centr. f. Bakt. Parasit. u. Infekt., 41, 321-339.

* Northrup, Zae 1914b A bacterial disease of June beetle larvae, Lactinosterna spp. Tech. Bull. Mich. Agri. Exp. Sta., No. 18, 37 pp.

Smyth, E. G. 1917 The white grubs injuring sugar cane in Porto Rico. 1. Life Histories of May-beetle. JI. Dept. Agr., Porto Rico, 1, No. 3, 141-169.

Smyth, E. G. 1920 The white grubs injuring sugar cane in Porto Rico. II. The rhinoceros beetles. Jl. Dept. Agr., Porto Rico, 4, No. 2, 3-29.

\section{MICROCOCCUS NITRIFICANS Bergey et al.}

Insect concerned: Lyreman cicada, Tibicen linnei.

Steinhaus (1941) isolated an organism similar to Micrococcus nitrificans from the Lyreman cicada. See Bergey's Manual for a description of this or yanism (5th ed., p. 257).

Steinhaus, E. A. 1941 A study of the bacteria associated with thirty species of insects. J. Bact., 42, 757-790.

\section{MICROCOCCUS NONFERMENTANS SteinhaUS}

Insects concerned: The lyreman cicada, Tibicen linnei; and an unidentified damsel fly (Coenagrionidae).

Micrococcus nonfermentans was isolated by Steinhaus (1941) from the alimentary tracts of the above insects.

* Steinhaus, E. A. 1941 A study of the bacteria associated with thirty species of insects. J. Bact., 42, 757-790.

\section{MICROCOCCUS OCHRACEUS ROsenthal}

Insects concerned: The imperial moth, Eacles imperialis; the nine-spotted lady-bug, Coccinella novemnotata. 
A description of the organisms may be found in Bergey's Manual (5th ed., page 242).

Steinhaus, E. A. 1941 A study of the bacteria associated with thirty species of insects. J. Bact., 42, 757-790.

\section{MICROCOCCUS OVATUS}

Insect concerned: Silkworm, Bombyx mori.

According to Northrup (1914), Pebrine, now known to be caused by a protozoan, was at one time supposed to be due to Micrococcus ovatus [Lebert, 1858].

Lebert, H. 1858 Berliner Entomologische Zeitschr. (From Northrup, 1914.)

Northrup, Z. 1914 A bacterial disease of the June beetles, Lachnosterna. Cent. f. Bakt. Parasit. u. Infekt., 4l, 321-339.

\section{MICROCOCCUS PARVULUS Bergey et al.}

Insect concerned: The American roach, Periplaneta americana.

Hatcher (1939) isolated Micrococcus parvulus from the feces of the American roach. Veillon and Zuber originally isolated this bacterium from human appendices, buccol cavities, and lungs, and named it Staphylococcus parvulus. In the third edition of Bergey's Manual, 1930, p. 92, this bacterium was called Micrococcus parvulus. In the 5 th edition, p. 285, the name has been changed to Veillonella parvula. A complete description may be found in Bergey's Manual.

Hatcher, E. 1939 The consortes of certain North Carolina Blattids. J. Elisha Mitchell Sci. Soc., 55, 329.

\section{MICROCOCCUS PIERIDIS Burrill}

Insect concerned: The cabbage butterfly, Pieris rapae.

Chittenden (1926) states, "In some seasons the larvae are destroyed in large numbers by a contagious bacterial diseased, caused by Micrococcus pieridis." However, as a rule the larvae are not very susceptible. 
Chittenden, F. H. 1926 The common cabbage worm and its control. U. S. Dept. Agr. Farmers' Bull., 1461, 13 pp., 1926.

\section{MICROCOCCUS PYOGENES AUREUS Migula \\ (See Staphylococcus aureus.)}

\section{MICROCOCCUS RUSHMORI BrOWn}

Insect concerned: Lucilia sericata.

Brown (1927) found Micrococcus rushmori to be a secondary invader in a disease of flies primarily caused by Bacillus lutzae. A complete description of the organism has been given by Brown.

Brown, F. M. 1927 Description of new bacteria found in insects. Am. Mus. Novitates, No. 251, 11 pp.

\section{MICROCOCCUS SUBFLAVUS Bumm}

Insect concerned: Grylloblatta campodeiformis campodeiformis.

Micrococcus subflavus was the identification given by Burroughs (1941) to a micrococcus he isolated from the alimentary tract of a grylloblattid. (A complete description of this micrococcus is given in Bergey's Manual, 5th ed., p. 248.)

Burroughs, A. L. 1941 Bacterial flora of the alimentary tract of Grylloblatta campodeiformis campodeiformis Walker. Montana State College Master's Thesis, $47 \mathrm{pp}$.

\section{MICROCOCCUS VULGARIS}

Insects concerned: Nun-moth, Lymantria monacha; Vanessa urticae; Pieris brassicae; and Liparis salicis.

Eckstein (1894) isolated this organism from sick nunmoths and from experimentally dead larvae of Vanessa urticae, Pieris brassicae, and Liparis salicis.

Eckstein, K. 1894 Untersuchungen ther die in Raupen vonkommenden Bakterien, Z. F. Forst- und Jagdwesen, 26, $3-20,228-298,413-424$. 
Genus: Sarcina

\section{SARCINA AURANTIACA Flügge}

Insect concerned: The honey bee, Apis mellifera.

Serbinow (1912) found this organism together with Sarcina lutea and Bacillus mesentericus in the dead larvae of honey bees. A complete description of Sarcina aurantiaca may be found in Bergey's Manual, 5th ed., p. 273.

Serbinow, I. L. 1912 Chernaia cherva. ("Black brood" in bees.) Vestnik Russkavo Obstschestva pchelovodstva, No. 11, Nov. 1912, 426-429.

\section{SARCINA FLAVA DeBary}

Insect concerned: Euxoa segetum; and the bedbug, Cimex lectularius.

Stutzer and Wsorow (1927) Lsolated Sarcina flava from the normal pupae of the Euxoa segetum. Steinhaus (1941) on one occasion found this organism as a fortuitous associate of the bedbug. A complete description may be found in the Bergey Manual, 5th ed., p. 272.

Steinhaus, E. A. 1941 A study of the bacteria associated with thirty species of insects. J. Bact., 42, 757-790. Stutzer, M. J. and Wsorow, W. J. 1927 Über Infectionen der Raupen der Wintersaateule (Euxoa segetum, Schiff.) Centr. f. Bakt. u. Parasit. 11, 113-129.

\section{SARCINA LOTEA Schroeter}

Insect concerned: The honey bee, Apis mellifera.

Serbinow (1912) in trying to determine the cause of "Blackbrood" among bees isolated Sarcina lutea from the dead larvae. A complete description may be found in the Bergey Manual (5th ed., p. 272.)

Serbinow, I. L. 1912 Chernaia Cherva. ("Black brood" in bees.) Vestnik Russkavo Obstschestva pchelovodstva, No. 11, Nov. 1912, 426-429. 


\section{STAPHYLOCOCCUS ACRIDICIDA Kuffernath}

Associated insects: Locusts, Pieris rapae and Locusta viridissima.

In 1913, Kuffernath (1921) received locusts from Greece which had been part of a disastrous invasion. He found the locusts infected with an organism which he isolated and named Staphylococcus acridicida, finding it to be closely allied to Staphylococcus pyogenes (Staphylococcus aureus). He described the organism in his paper.

In the title of his paper (see below) he refers to the organism as Micrococcus (Staphylococcus) acridicida.

* Kuffernath, H. Microbe pathogene pour les Sauterelles et d'autres insectes, Micrococcus (Staphylococcus) acridicida, Kuff. Nov. spec.--Ann. Gembloux, Brussels, 27, 253-257.

\section{STAPHYLOCOCCUS ALBUS ROsenbach}

Insects and ticks concerned: The oriental roach, Blatta oriontalis; the croton bug, Blattella germanica; the stable fiy, Stomoxys calcitrans; the bedbug, Cimex lectularius; the house fly, Musca domestica; the mosquitoes, Aedes cinereus and Anopheles bifurcatus; Rhodnius prolixus; and the ticks, Argas persicus and Ornithodoros moubata.

Tauber (1940) found in the hemolymph of the oriental roach, two organisms which were pathogenic for the insect. One was an unidentified rod, and the other was Staphylococcus albus. Just how the bacteria made their entrance into the hemolymph of normal roaches was not clear. He suggested, however, that after the insect molts, the exoskeleton is very soft and is easily injured. Then the uninfected roaches come in contact with the infected ones, and the bacteria penetrate the delicate newly exposed exoskeleton, or pass through breaks in the surfaces and so into the hemolymph.

According to Herms (1939) Staphylococcus albus has been isolated from the legs of the croton bug, Blattella germanica.

Duncan (1926) found the gut-contents of Argas persicus, Ornithodoros moubata, and stomoxys calcitrans but not 
Cimex lectularius, Rhodnius prolixus, Musca domestica, Aedes cinereus, and Anopheles bifurcatus to be bactericidal to staphylococcus albus.

Staphylococcus $\overline{\text { albus }}$ is described in the 5 th edition of Bergey's Manual, p. 261.

Duncan, J. T. 1926 On a bactericidal principle present in the alimentary canal of insects and arachnids. Parasitol., 18, 238-252.

Herms, W. B. 1939 Medical Entomology, 3d ed., 582 pp. (see p. 75). MacMillan Co., New York.

Tauber, O. E. 1940 Mitotic response of roach hemocytes to certain pathogenes in the hemolymph. Ann. Entomol. Soc. Am., 83, 113-119.

\section{STAPHYLOCOCCUS AUREUS ROsenbach}

Insects and ticks concerned: The silkworm, Bombyx mori; the roaches Blattella germanica, and Periplaneta orientalis; the stable fly, Stomoxys calcitrans; the bedbug, Cimex lectularius; the house fly, Musca domestica; the mosquitoes, Aedes cinereus, Aedes aegypti, and Anopheles bifurcatus; Rhodnius prolixus; and the ticks, Argas persicus, Argas reflexus; and Ornithodoros moubata.

Sawamura (1906) lists Micrococcus pyogenes aureus [Scaphylococcus aureus] as being experimentally pathogenic to the silkworm. Galli-Valerio (1907) refers to staphylococcus pyogenes aureus as having been spread by the tick, Argas reflexus. probably Periplaneta orientalis, carried Staphylococcus aureus on their legs. According to Herms (1939) this coccus also has been isolated from the antennae of the croton bug (Blattella germanica).

Hindle and Duncan (1925) found Staphylococcus aureus to die out quickly after ingestion by the tick, Argas persicus. Duncan (1926) supported these results by the observation that this coccus was greatly inhibited by the sui-contents of the tick. The same bactericidal effect against this organism was found by Duncan to be characteristic of the gut-contents of Ornithodoros moubata and Stomoxys calcitrans but not by Cimex lectularius, Rhodnius prolixus, Musca domestica, Aedes cinereus, and Anopheles bifurcatus.

St. John, Simmons, and Reynolds (1930) found StaphyIococcus aureus to survive for at least 24 hours in the gut of the mosquito, Aedes aegypti, though it could not be demonstrated after an interval of seven or more days. 
A complete description of Staphylococcus aureus may be found in Bergey's Manual, 5th edition, p. 262.

Duncan, J. T. 1926 On a bactericidal principle present in the alimentary canal of insects and arachnids. Parasitol., 18, 238-252.

Galli-Valerio, B. 1907 Les insects comme propagateurs, des maladies: Le role des arthropodes dans la dissemination des maladies. Ber. U. d. XIV Internat. Kongr. f. Hygiene u. Demogr., Berlin, 189-194.

Herme, W. B. 1939 Medical Entomology. 3rd ed., 582 pp. MacMillan Co., New York.

Hindle, E., and Duncan, J. T. 1925 The viability of

bacteria in Argas persicus. Parasitol., 17, 434-446. Longfellow, R. C. 1913 The common house roach as a carrier of disease. Am. J. Pub. Health, 3, 58-61. Sawamura, S. 1906 Note on bacteria pathogenic to silkworm. Tokyo Imp. Univ. Coll. Agr. Bull., l, 105. St. John, J. H., Simmons, J. S., and Reynolds, F. H. K. 1930 The survival of various microorganisms within the gastro-intestinal tract of Aedes aegypti. Amer. J. Trop. Med., 10, 237-24l.

\section{STAPHYLOCOCCUS CITREUS (Migula) Bergey et al.}

Insect concerned: The cockroach, Periplaneta orientalis.

Longfellow (1913) found that cockroaches carried Staphylococcus citreus on their legs.

Longfellow, R. C. 1913 The common house roach as a carrier of disease. Am. J. Pub. Health, 3, 58-61.

\section{STAPHYLOCOCCUS INSECTORUM Krassilstschik}

Insect concerned: The silkworm, Bombyx mori.

Krassilstschik isolated and named Staphylococcus insectorum, and thought it was found normally in the intestinal tract of the silkworm. (See Paillot, 1928).

Paillot, A. 1928 Les maladies du ver a soie Grasserie et dysenteries. $328 \mathrm{pp}$. Editions du Service Photographique d L'Universite Lyon. (See p. 171-172. 


\section{STAPHYLOCOCCUS MUSCAE Glaser}

Insect concerned: The house fly, Musca domestica.

Glaser (1924) isolated and named Staphylococcus muscae. He found it to be the cause of a fatal infection in the house fly. The disease is rather sporadic and never assumes the form of an epidemic, only about 50 per cent of adult flies contracting the infection when experimentally infected. Males were more susceptible than females.

A complete description of the organism may be found in Bergey's Manual, 5th ed., p. 264.

*Glaser, R. W. 1924 A bacterial disease of adult house

flies. Am. J. Hyg., 4, 411-415.

$\frac{\text { STAPHYLOCOCCUS }}{\text { PARVULUS Veillon and Zuber }}$

$\frac{\text { STAPHYLOCOCCUS }}{\text { PYOGENES }} \frac{\text { AUREUS }}{\text { Staphylococcus aureus.) }}$

Family: NEISSER IACEAE

Genus: Neisseria

NEISSERIA CATARRHALIS (Frosch and Kolle) Holland

Tick concerned: Argas persicus.

Duncan (1926) found the gut-contents of Argas persicus possessed a bactericidal principle active against Micrococcus catarrhalis (Neisseria catarrhalis)and other bacteria. (For complete description see Bergey's Manual, 5th edition, p. 280.)

Duncan, J. T. 1926 on a bactericidal principle present in the alimentary canal of insects and arachnids. Parasitol., 18, 238-252.

NEISSERIA LUCILIARUM BrOWN

Insect concerned: The green fly, Lucilia sericata. 
Brown (1927) isolated this gram-negative, motile, coccus from dead Iucilia sericata which has been killed by Bacillus lutzae (which see). Taxonomically, according to Brown, this organism should be placed near Neisseria perflava Bergey et al. (See Bergey's Manual, $\overline{1939,5 \text { th }}$ ed., p. 281.)

* Brown, F. M. 1927 Descriptions of new bacteria found in insects. Amer. Mus. Novitates, No. 25l, 11 pp.

Genus: Veillonella

VEILLONELLA PARVULA Bergey et al. (See Micrococcus parvulus.)

Family: PARVOBACTER I ACEAE

Tribe: BRUCELLEAE

Genus: Brucella

BRUCELLA ABORTUS (Schmidt and Weis) Meyer and Shaw

insects concerned: The cockroach, Periplaneta americana; and the flies, Musca domestica, Muscina stabulans, Stomoxys calcitrans, Caliphora sp., and Lucilia sp.

Ruhland and Huddleson (1941) in attempting to account for the appearance of brucellosis in non-infected herds kept under ideal conditions fed the above insects for two hours on a virulent strain of Brucella abortus after which the insects were examined bacteriologically. In the 110 cockroaches tested the bacterium did not remain alive in their intestinal tract for more than 24 hours. "Data obtained from the flies indicate that the amount of growth obtained by culturing the droplets was heavier and more free from contamination 48 hours after exposure than at earlier periods. Although no flies were cultured later than 96 hours after exposure, it is possible that they carry the organism for a considerable period of time."

According to Patton (1931) Wollman found that flies kept in contact with Brucella abortus for 48 hours, and then placed in a tube containing culture medium, remained infective for 24 hours but not later. 
Patton, W. S. 1931 Insects, ticks, mites, and venomous animals of medical and veterinary importance. Part II. - Public Health. 740 pp., H. R. Grubb, Ltd., Croydon. Ruhland, H. H., and Huddleson, I. F. 1941 The role of one species of cockroach and several species of flies in the dissemination of Brucella. Amer. J. Vet. Res., 2, $371-372$.

Tribe: HEMOPHILEAE

Genus: Hemophilus

HEMOPHILUS DUPLEX (Lehman and Neuman) comb. nov.

Insect concerned: The house fly, Musca domestica.

According to Patton.(1931), Wollman placed house flies in tubes containing cultures of Bacillus aegyptius and the Morax-Axenfeld bacillus (Hemophilus duplex) of 'subacute conjunctivitis and observed that they became infective immediately afterwards, though they were not infective after three and one half hours.

Patton, W. S. 1931 Insects, ticks, mites, and venomous animals of medical and veterinary importance. Part II. Public Health. 740 pp. H. R. Grubb, Ltd., Croydon.

\section{Tribe: Pasteurelleae}

Genus: Pasteurella

PASTEURELLA CUNICULICIDA (FIllgge) Trevisan

Insect concerned: The house fly, Musca domestica.

Scott (1917) has reported the isolation of Bacillus (now Pasteurella) cuniculicida from the house fly.

Scott, J. R. 1917 Studies upon the common house-fly (Musca domestica Linn.) II. Isolation of $\underline{B}$. cunicuIicida, a hitherto unreported isolation. 37, $121-124$. 


\section{PASTEURELLA PEST IS (Lehmann and Neumann) \\ Bergey et al.}

Insects concerned: Plague bacilli have been cited as associated with an extensive number of arthropods. The species listed below are perhaps the most important and representative ones from the standpoint of plague transmission.

Fleas: Xenopsylla cheopis; Xenopsylla astia; Xenopsylla brasiliensis; Diamanus montanus (Ceratophyllus acutus); $\overline{\text { Nosopsyllus fasciatus }}$ ( Ceratophyl $\overline{\text { lus fasciatus }}$; Monopsyllus anisus (Ceratophyllus anisus); Oropsylla silantiewi; Ceratophyllus tesquorum; Dinopsyllus lypusus; Leptcpsylla musculi; Ctenophthalmus agyrtes; Pulex irritans; Ctenophthalmus agyrtes; Pulex irritans; Ctenocephalides canis; Ctenocephalides felis; Ceratophyllus gallinae.

The reader is referred to the work of Eskey and Haas (1940) for a list of other species of fleas which are potential vectors of plague, especially among rodents.

Lice: Haematopinus columbianus; Linognathoides citelli.

The implications against many of the following have been mainly of an incidental nature and are concerned largely with experimental findings:

Ticks: Ixodes autumnalis; Rhipicephalus schulzei; Argas persicus; Hyalomma volgense; Dermacentor silvarum.

Flies: Musca domestica; Stomoxys calcitrans.

Beetles: Necrophorus dauricus and others.

Mosquitoes: Culex pipiens, Ä̈des aegypti.

Ants, roaches, and mites have also been suspected of carrying plague bacilli.

The plague bacillus was discovered in 1894 independently by Kitasato and by Yersin.

Three years later Ogata (1897) and soon thereafter Simond (1898) pointed out, on epidemiologic and experimental ground, the role of the flea in the transmission of plague bacilli. However, it was the English Plague Research Commission that clarified and established the essential part that fleas play in the spread of plague, especially among rodents.

Although the number of fleas known to transmit the plague bacillus is large and ever-increasing, the principal vector is the rat-flea Xenopsylla cheopis. It is present on wild rats in many parts of the world and is the predominant species in India, Java, Egypt, and most parts of China. Besides its widespread occurrence, there are other factors which make this species an efficient vector. As stated by Eskey (1938); "When compared with all other 
species studied, Xenopsylla cheopis are considered the most efficient transmitting agents because they are more readily infected when fed on septicemic blood, and they transmitted the disease to many more guinea pigs. They also tend to become blocked earlier and to remian infectious for a longer time than other fleas. Blocked cheopis are very persistent in their efforts to obtain blood . . "

According to Lien-teh, Chun, Pollitzer, and Wu (1936), Xenopsylla astia is not as important as $x$. cheopis in the transmission of plague though it may be the responsible vector in certain circumscribed and isolated outbreaks. $\underline{X}$. brasiliensis is the predominant rat-flea of Uganda, $\bar{K}$ enya and Nigeria, and has been known to transmit plague from rat to rat and from rat to man. Nosopsyllus fasciatus, the so-called European rat-flea, attacks man less readily than $\underline{X}$. cheopis and does not predominate on rats in plague areas. Leptopsylla musculi likewise does not readily bite man and is of minor importance in the spread of the disease.

In some parts of the world plague is harbored in animals other than the rat. In such cases the ectoparasites of these animals are of importance in maintaining the disease. Chief of these are Diamanus montanus, found on the ground squirrels of California; Oropsylia silantiewi; found on the tarbagan of Mongolia; Ceratophyllus tesquorum, carried by the suslik or marmot of Southeastern Russia; and Dinopsyllus lypusus found on the gerbille of Africa.

As indicated in the list of arthropods above, besides fleas, other insects including flies, ants, beetles, mosquitoes, and roaches have also been suspected of carrying plague bacilli.

Data concerning the possible role of ticks in the transmission of plague is very meager. Skorodumoff, in 1928, (quoted by Lien-teh, et al., 1936) was among the first to obtain positive experimental results. He infected a wild mouse and a guinea pig from crushed suspension of ixodid ticks. In 1929, Tikhomirova and Nikanoroff (Lien-teh, et al., 1936) found three ticks (Ixodes autumnalis) upon the carcass of an experimentally infected tarabagan. The tissues of these ticks yielded positive cultures of the plague bacillus and was infective to guinea pigs. Faddeeva (1932) fed Argas persicus on infected guinea pigs when the bacteremia was most marked. Both the inoculation and the culture experiments gave positive results. Borzenkov and Donskov (1933) reported the finding of plague bacilli in Ixodes autumnalis and Rhipicephalus schulzei taken from animals infected with plague (see also Gaisky (1931)). These workers also found that Hyalomma volgense, from 
larval to adult stages, can be infected with plague by feeding on infected animals. These authors also state that "by the direct bites the plague infected adults may cause an infection and death in healthy animals." Sassuchin and Tichomirova (1936) have reported studies on the survival of plague bacilli in the larvae and nymphae of Dermacentor silvarum. Over 60 per cent of both nympahe and larvae died during the experiments, suggesting that Pasteurella pestis was pathogenic to them.

For a bacteriologic description of Pasteurella pestis see Bergey's Manual (5th ed., page 294).

Borzenkov, A., Donskov, G. 1933 The experimental infection of the tick Hyalomma volgense P. Schulze et E. Schlottke, 1929, with plage. Rev. Microbiol. Epidermiol. et Parasitol. , 12, 30.

Eskey, C. R. $193 \overline{8}$ Fleas as vectors of plague. Am. J. Publ. Health, 28, 1305-1310.

Eskey, C. R., and Haas, V. H. 1940 Plague in the western part of the United States. U. S. Public Health Bul. No. 254, $83 \mathrm{pp}$.

Faddeeva, T. 1932 The role of ticks in the transmission and preservation of plague virus. Rev. Microbiol. Epidemiol. et Parasitol., 12, 279.

*Kitasato, S. 1894 Preliminary note on the bacillus bubonic plague. Lancet, $\underline{2}, 428$.

Lien-teh, W., Chun, J. W., Pollitzer, R., and Wu, C. Y. 1936 Plague. A manual for medical and public health workers. $547 \mathrm{pp}$. The Mercury Press, Shanghai.

Ogata, M. 1897 Ueber der Pestepidemie in Formosa. Zbl. Bakt., 21, 744 .

Sassuchin, D., and Tichomirova, M. 1936 De la conservation des Pasteurella pestis dans les larves et les nymphes des tiques Dermacentor silvarum Olen. Rev. Microbiol., Peidemiol. et Parasitol., 15, 362. Simond, P. L. 1898 La propagation de la peste. Ann. Inst. Pasteur, 12, 625.

*Yersin, A. 1894 La peste bubonique a Hong Kong. Ann. Inst. Pasteur, $\underline{8}, 662$.

\section{PASTEURELLA TULARENSIS}

(McCoy and Chapin) Bergey et al. ${ }^{1}$

$l_{\text {Explanatory note: Considerable disagreement persists as }}$ to the correct classification and naming of this bacterium. Serologically it is allied to the members of the genus Brucella and hence is called Brucella tularensis by English writers. However, the importance of this as a 
taxonomic criterion would mean little if the findings of Mallman (1930) concerning the common antigenicity of Brucella, Pasteurella, and Pfeifferella are correct. Although originally named Bacterium tularense by McCoy and Chapin, more recent classifications have placed the organism in the genus Pasteurella because of its similarities with other members of the genus, especially Pasteurella pestis. These organisms agree to a large extent in pathogenicity, pathologic manifestations, morphology, fermentation reactions, selective affinity for rodent and human hosts, and in insect transmission. The tularaemia organism differs from other members of the genus in the difficulty in growing it on ordinary bacteriologic media. Inasmuch as we have arbitrarily followed the systematics of the Bergey Manual, we have used the name Pasteurella tularensis for the sake of consistency.

Insects concerned: The squirrel flea, Ceratophyllus acutus; the deer fly, Chrysops discalis; the rabbit louse, Haemodipsus ventricosus; the mouse louse, Polyplax serratus; the bedbug, Cimex lectularius; the fleas, Ctenophthal-

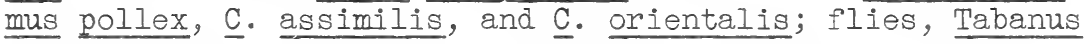
autumnalis; $\bar{T}$. agrestis, $\underline{T}$. bromius, T. erberi, T. flavoguttatus, T. solstitialis, T. peculiaris, $\underline{T}$. karybenthinus, T. turkestanus, T. septentrionalis, T. rupestris, Chrysops

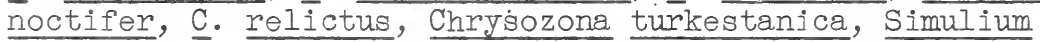
decorum katmai, Neohaematopinus laeviusculus, Stomoxys calcitrans, Spilopsyllus cuniculi, Cediopsylla simplex; mites of the family Gamasidae; the ticks, Dermacentor andersoni, D. albipictus, D. occidentalis, D. variabilis, D. parumapertus (marginatus), D. silvarum, Haemaphysalis Ieporis-palustris; Ixodes ricinus californicus; Ornithodoros turicata, $\underline{0}$ parkeri, $\underline{0}$. hermsi, $\underline{0}$ lahorensis, Rhipicephalus sanguineus; Ambilyomma americanum; mosquitoes

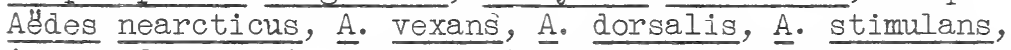
A. canadensis, $\underline{A}$. aegypti, A. caspius, Theobaldia incidens,

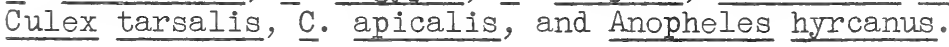

In 1911 McCoy described a plague-like disease of ground squirrels (Citellus beecheyi) of California. The following year McCoy and Chapin (1912) described "Bacterium tularense" as the causative agent. The disease was later named "tularemia" by Francis. During his original investigations McCoy (1911) found it possible to reproduce the infection in guinea pigs by the subcutaneous inoculation of crushed squirrel fleas (Ceratophyllus acutus) which had been removed from recently dead rodents. Ten years later, Francis and Mayne (1921) reported experimental transmission 
of tularemia by the blood-sucking deer fly, Chrysops discalis. This was followed by similar reports by Francis and Lake (1921, 1922a, 1922b) involving the rabbit louse, Haemodipsus ventricosus, the bedbug, Cimex lectularius, and the mouse louse, Polyplax serratus.

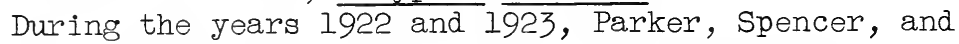
Francis (1924) made observations which indicated the spontaneous occurrence of the tularemia organism in the tick Dermacentor andersoni. They also demonstrated stageto-stage transmission of the bacterium from larva to adult tick. Later, Parker and Spencer (1926) proved the hereditary transmission of Pasteurella tularensis (Bacterium tularense) in Dermacentor andersoni. This appears to have been the first recorded instance of the hereditary transmission of a known pathogenic bacterium by an arthropod.

Parker and his associates (Davis, Philip, and Jellison) have made numerous other studies regarding the association of arthropods and the tularemia bacterium. As to their findings, we quote. from Parker (1933):

"(a) The demonstration of the survival of Bact. tularense from the larvae through to the adults of both $\underline{H}$. leporis-palustris and D. variabilis, its transmission by the successive stages involved, and generation-to-generation transmission from infected females to their progeny.

(b) Larval to adult survival in, and transmission by, the successive stages of the brown dog tick, $\underline{R}$. sanguineus, and the lone-star tick, A. americanum, within a single generation.

(c) Survival in, and later transmission by adult rabbit dermacentor, D. parumapertus marginatus, and the Pacific Coast tick, D. occidentalis, that had previously ingested virus.

(d) Mechanical transmission to guinea pigs by Tabanus septentrionalis, by another species of horsefly tentatively identified as T. rupestris, and by Chrysops noctifer, and the survival of viable

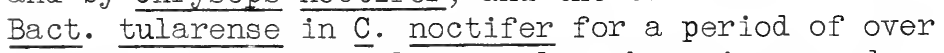
a month. Survival only was also shown in an undetermined species of Ceratopogonidae. [Philip, unpublished experiments.]

(e) Failure to transmit infection by species of fleas occurring in the native Montana fauna.

(f) Mechanical transmission by immediate interrupted feeding by the black fly, Simulium decorum katmai. [Philip, unpublished experiments.]

(g) Transmission by the sucking louse, Neohaematopinus laeviusculus, of the Columbian ground squirrel. 
(h) The repeated recovery of Bact. tularense from specimens of H. leporis-palustris collected from rabbits and grouse in Morrison County, Minnesota, in 1931 and 1932. (These tests were made in conjunction with Dr. R. G. Green of the University of Minnesota Medical School.)"

According to other reports, Pasteurella tularensis has been found spontaneously in Dermacentor occidentalis (Parker, Brooks, and Marsh, 1929), Ixodes ricinus californicus (Davis and Kohls, 1937), and Dermacentor variabilis (Green, 1931). Kamil and Bilal (1938) have reported the transmission by Ornithodoros lahorensis. Zasukhin (1936) mentions that in 1934 Golov showed that Dermacentor silvarum can be infected with Pasteurella tularensis and that it does not lose the infection from one stage to the next. Davis (1940) has found that the tularemia bacterium may survive in the tissues of Ornithodoros turicata and Ornithodoros parkeri, "but is not transmitted by the ticks during feeding.

Volfrz, Kolpakova, and Flegontoff (1934) have reported the survival of Pasteurella tularensis in mites of the family Gamasidae and in the fleas, Ctenophthalmus pollex and possibly Ctenophthalmus orientalis. Green and Evans (1938) isolated the bacterium of tularemia from fleas (Spilopsyllus cuniculi) removed from snowshoe hares and from cottontail rabbits. Waller (i940) recovered Pasteurella tularensis from Cediopsylla simplex collected from a sick cottontail rabit. Philip, Davis, and Parker (1932) using Agdes nearcticus, A. vexans, A. dorsalis, A. stimulans, A. aegypti, A. canädensis, Théobaldia incidens, and Culex tarsalis, showed experimentally that the mosquito could be a significant factor in the epidemiology of tularemia by infecting persons mechanically (1) biting, (2) being crushed on the skin, and (3) by depositing excrement on the skin. Bozhenko (1936) demonstrated that Pasteurella tularensis may survive in Culex apicalis and in the feces of this insect. This worker (1935) has also found that transmission of tularemia by the bites of infected bedbugs was successful 15 hours after an infective feeding and that organisms remain virulent in the bugs for as long as 136 days after feeding.

In recent years Olsufiev and Golov, 1939; and Olsufiev, 1939a, b, c; 1940a, b, have gathered considerable data on the transmission of tularemia implicating horse flies, the stable fly, the rain fly, mosquitoes, and other insects.

For a description of Pasteurella tularensis see Bergey's Manual ( 5 th ed.). 
Bozhenko, V. P. 1935 The role of bed bugs (Cimex lectularius L.) in transmission and preservation of tularaemia virus. (In Russian.) Rev. Microbiol., 14, 436-440.

Bozhenko, V. P. 1936 on the role of the mosquitoes, Culex apicalis Ad., as carriers and transmitters of tularaemia. (In Russian.) Rev. Microbiol., 15, 445-449. Davis, G. E. 1940 Bacterium tularense: Its persistence in the tissues of the argasid ticks Ornithodoros turicata and $\underline{0}$. parkeri. Pub. Health Rep., 55, 676-680. Davis, G. E., and Kohls, G. M. 1937 Ixodes ricinus californicus (Banks) as a possible vector of Bacterium tularense. Pub. Health Rep., 52, 281-282.

Francis, E., and Lake, G. C. 1921 Experimental transmission of tularaemia in rabbits by the rabbit louse, Haemodipsus ventricosus (Denny). Pub. Health Rep., 36, $1747-1753$.

Francis, E., and Lake, G. C. $1922 a$ Transmission of tularaemia by the bedbug, Cimex lectularius. Pub. Health Rep., 37, 83-95.

Francis E., and Lake, G. C. 1922b Transmission of tularaemia by the mouse louse Polyplax serratus (Burm.). Pub. Health Rep., 37, 96-101.

Francis E., and Mayne, B. 1921 Experimental transmission of tularaemia by flies of the species Chrysops discalis. Pub. Health Rep., 36, 1738-1746.

Green, R. G., and Evans, C. A. 1938 Role of fleas in the natural transmission of tularaemia. Minn. Wildlife Dis., Invest., April, 1938; pp. 25-28.

Kamil, S., and Bilal, S. 1938 Experimental research on the etiology of tularaemia in Turkey. Ann. de Parasit., $16,530-542$.

Mallman, W. L. 1930 J. Am. Vet. Med. Assoc., 77, 636. McCoy, G. W. 1911 A plague-like disease of rodents.

Pub. Health Bul. No. 43, pp. 53-71.

*McCoy, G. W., and Chapin, C. W. 1912 Bacterium tularense, the cause of a plaguelike disease of rodents. Bul. No. 53, Hyg. Lab., U.S.P.H.S. (January). (See also J. Infectious Diseases, 1912, 10, 61.)

Olsufiev, N. G., and Golov, D. A. 1936 Horse flies as transmitters and conservators of tularemia. Animaux pathogenes, 2, 187-226. (In Russian with English summary.)

Olsufiev, N. G. 1939a The role of Stomoxys calcitrans L. in the transmission and preservation of tularemia infection. Arkhiv. biologicheskikh nauk., 58, 25-31. (In Russian with English summary.) 
Olsufiev, N. G. 1939b The role of mosquitoes in the transmission and retention of tularemia. Problems of regional parasitology, 3, 213-246. (In Russian with English summary.)

Olsufiev, N. G. 1939c The specific composition and seasonal dynamics of the blood-sucking diptera numbers in the delta of the Volga and their possible role in the epidemiology of tularemia. Zoologichesku zhurnal, 18, 786-798. (In Russian with English summary.)

olsufiev, N. G. 1940a Nouvelles données expérimentales sur la transmission de l'infection tularémique par les taons (Tabanus). Meditsinskaia parasitologiia i parazitariye bolezni, 2, 260-270. (In Russian with French summary. )

Olsufiev, N. G. 1940b Results of studies of transmitters of tularemia in U.S.S.R. Proc. of the All-Union Congress of Microb., Epidemiol., and Infectionists, 1939; Moscow, 1940, pp. 247-253.

Parker, R. R. 1933 Recent studies of tick-borne diseases made at the United States Public Health Service Laboratory at Hamilton, Montana. Proc. 5th Pacific Sci. Congress, 6, 3367-33.74.

Parker, R. R., Brooks, C. S., and Marsh, H. 1929 The occurrence of Bacterium tularense in the wood tick, Dermacentor occidentalis in California. Pub. Health Rep., 44, 1299-1300.

Parker, R. R., and Spencer, R. R. 1926 Hereditary transmission of tularaemia infection by the wood tick, Dermacentor andersoni Stiles. Pub. Health Rep., 4l, 1403-1407.

Parker, R. R., Spencer, R. R., and Francis, E. 1924 Tularaemia infection in ticks of the species Dermacentor andersoni Stiles in the Bitterroot Valley, Mont. Pub. Health Rep. , 39, 1057-1073.

Philip, C. B., Davis, G. E., and Parker, R. R. 1932 Experimental transmission of tularaemia by mosquitoes. Pub. Health Rep., 47, 2077-2088.

Volferz, A. A., Kolpakov, S. A., and Flegontoff, A. A. 1934 The role of ectoparasites in the tularaemic epizootic of the ground squirrels. Rev. Microbiol. Epidemiol. et Parasitol., 13, 103-116.

Waller, E. F. 1940 Tularemia in Iowa cottontail rabbits (Sylvilagus floridanus mearnsi) and in a dog. Vet. student, ?, pp. 54, 55, 73 .

Zasulthin, D. N. 1936 The ticks (Ixodidae) and their role in epizootology and epidemiology of tularaemia in the south-east of the U.S.S.R. (In Russian.) Rev. Microbiol., 15, 461-470. 


\title{
Family: PSEUDOMONADACEAE
}

\author{
Tribe: PSEUDOMONADEAE
}

Genus: Phytomonas

\section{PHYTOMONAS CAMPESTRIS (Pammel) Bergey et al.}

Insect concerned: Plusia brassicae; Agriolimax agrestis L.

Pammel (1895) first isolated Bacillus (Phytomonas) campestris from diseased rutabagas. Two years later Smith (1897) showed experimentally that this organisn, which causes black rot of crucifers, could be transmitted by slugs, Agriolimax agrestis L., and the cabbage worm, Plusia brassicae. No actual proof of the insect transmission of this disease in the field has, as yet, been forthcoming.

For a description of this organism see Bergey's Manual (5th ed., page 148).

* Pammel, L. H. 1895 Bacteriosis of rutabaga (Bacillus campestris, n. sp.). Iowa Agr. Exp. Sta. Bul. 27, $130-134$.

Smith, E. F. 1897 Pseudomonas campestris (Pammel), the cause of a brown rot in cruciferous plants. Zent. Bakt. II., 3, 284-291, 408-415, 478-486.

\section{PHYTOMONAS MEDICAGINIS VAR. PHASEOLICOLA (Burkholder)}

Insect concerned: The thrip, Heliothrips femoralis.

This bacterium was isolated from leaves, pods, and stems of beans afflicted with halo blight. Buchanan (1932) showed that this bacterial disease of beans was transmitted by the thrip Heliothrips femoralis. The bacterial lesions on the plants are always associated with the feeding wounds of the insect. According to Leach (1940), the transmission appears to be incidental and entirely mechanical and under field conditions the insect is probably of little importance as a vector of the disease.

For a description of this organism see Bergey's Manual (5th ed., page 194). 
Leach, J. G. 1940 Insect transmission of plant diseases. 615 pp. McGraw-Hill Book Company, New York.

\section{PHYTOMONAS MELOPHTHORA Allen and Riker}

Insect concerned: The apple maggot, Rhagoletis pomonella.

This bacterium is pathogenic for apples and is found associated with the apple maggot, Rhagoletis pomonella.

Allen and Riker (1932) studied the decay of apples which frequently follows infestation by the apple maggot. They associated the decay with a bacterium which they named Phytomonas melophthora. Besides being associated with the larvae, this bacterium has been found both in and on male and female flies.

For a description of this organism see Bergey's Manual (5th ed., page 199).

*Allen, T. C., and Riker, A. J. 1932 A rot of apple fruit caused by Phytomonas melophthora, n. sp., following invasion by the apple maggot. Phytopath., 22, 557571.

\section{PHYTOMONAS PSEUDOTSUGAE (Hansen and Smith)}

Insect concerned: Chermes cooleyi.

Phytomonas pseudotsugae was isolated from galls on Douglas fir (Pseudotsuga taxifolia) in California. Hansen and Smith (1937) designated the causative agent Bacterium pseudotsugae, which has since been placed in the genus Phytomonas. The infection depends on deep wounds which suggests transmission by an insect vector. Strong circumstantial evidence incriminates Chermes cooleyi, a sucking insect.

See Bergey's Manual (5th ed., page 209) for a description of this organism.

*Hansen, H. N., and Smith, R. E. 1927 A bacterial gall

disease of Douglas fir, Pseudotsuga taxifolia. Hilgardia, $\underline{10}, 569-577$. 


\section{PHYTOMONAS SALICIPERDA (Lindeijer) Magrou}

Insect concerned: The willow borer, Cryptorrhynchus lapathi.

Lindeijer (1932) described a bacterial disease of willows (Salix spp.), caused by Pseudomonas saliciperda, and since placed in genus Phytomonas.

According to Leach $(194 \overline{0})$, the disease causes a wilt of the branches followed by early defoliation and death of the affected limbs. Natural infections most frequently originate at the sight of wounds made by the willow borer, which, after having been contaminated with the bacteria, infects the tree. The disease has been experimentally produced by allowing infected insects to feed on willow twigs.

For a description of this organism see Bergey's Manual (5th ed., p. 204).

Leach, J. G. 1940 Insect transmission of plant diseases. 615 pp. McGraw-Hill Book Company, New York. *Lindeijer, E. J. 1932 De bacterie-ziekte van den wilg veroorzakt door Pseudomonas saliciperda n. sp. Thesis Univ. of Amsterdam, Baarn, pp. 1-82.

\section{PHYTOMONAS SAVASTANOI (Smith) Bergey et al.}

Insect concerned: The olive fly, Dacus oleae.

Phytomonas savastanoi gives rise to a disease of olive tree on which "knots" or galls result from the infection. The disease is prevalent in Italy and other southern European countries, although Smith isolated cultures from olive galls collected in California where the disease has been known since 1898.

In Italy there appears to be a close association between the olive fly, Dacus oleae, and the spread of the disease. Petri (1909, 1910) studied the relationships between this insect and bacteria found in the intestinal tract of the insect. Ascobacterium luteum (which see) is one of the nonpathogenic bacteria which Petri found occurring as a "symbiote" in the olive fly and from the four blind appendages of the middle stomach of the larvae of Dacus oleae, he (1910) isolated Bacterium savastanoi (Phytomonas savastanoi). According to Buchner (1930) the latter organism is the real "symbiont" associated with the olive fly. The bacteria are transmitted through the egg and persist in 
the puparium. Petri suggested that the physiological role of the bacteria in the digestive tract is probably connected with the feeding habit of the larva, which bores in olives, a food which is rich in fats. The larva has to ingest very large quantities of oil in order to extract onough nitrogenous substances necessary for its development. The bacteria in the digestive tract may be useful in breaking down the fats and releasing the nitrogen.

For a description of this organism see Bergey's Manual (5th ed., page 207), and Bacterium savastanoi in Elliott (1930).

Buchner, P. 1930 Tier und Pflanze in Symbiose. 900 pp. Borntraeger, Berlin. (See page 312.)

Elliott, C. 1930 Manual of bacterial plant pathogens. 349 pp. Williams and Wilkins Company, Baltimore. (See page 198).

Petri, L. 1909 Ricerche sapra i batteri intestinali della Mosca olearia: Memorie R. Staz. Patol. Veg. Roma, 4, 1.-130.

Petri, L. 1910 Untersuchungen uber die Darmbakterien der Olivenflige. Zentrabl. Bakt. II, 26, 357-367.

\section{PHYTOMONAS SOLANACEARUM (Smith) Bergey et al.}

Insect concerned: The potato beetle, Leptinotarsa decimIineata.

In warm, moist climates this bacterium attacks potatoes, tobacco, tomatoes, peppers, and other related plants. According to Leach (1940), the bacteria are found first in the vascular bundles but eventually they enter the parenchyma cells of the cortex and pith. After spreading through the vascular bundles of the stolons they reach the tubers where they decay the storage tissues.

Smith (1896) incriminated the Colorado potato beetle as a disseminator of the disease on the basis of greenhouse experiments. He named the bacterium Bacillus solanacearum though it is now placed in the genus Phytomonas. For a description of this organism see Bergey's Manual (5th ed., page 203).

Leach, J. G. 1940 Insect transmission of plant diseases. $615 \mathrm{pp}$. McGraw-Hill Book Company, New York. 'Smith, E. F. 1896 A bacterial disease of the tomato, eggplant, and Irish potato (Bacillus solanacearum n. sp.). U. S. Dept. Agr. Div. Physiol. and Path. Bul. 12. 
Insects concerned: Phyllophaga sp.; Chaetocnema denticulata; Chaetocnema pulicaria; Diabrotica duodecimpunctata; Diabrotica longicornis.

Phytomonas stewarti is a bacterium which gives rise to a wilt in corn (Zea mays). Sweet corn seems to be the most susceptible, although, according to Leach (1940), teosinti (Euchlaena mexicana), and Tripsacum dactyloides are known to be susceptible. The organism is essentially a vascular pathogen although other tissues are frequently affected.

Rand (1923) was the first to prove that insects could disseminate the disease. He demonstrated that the brassy flea beetle, Chaetocnema pulicaria was responsible for the secondary spread of wilt in midsummer.

For a description of this bacterium see Bergey's Manual (1939) 5th ed., page, 214).

Leach, J. G. 1940 Insect transmission of plant diseases. 615 pp. McGraw-Hill Book Company, New York.

Rand, F. V. 1923 Bàcterial wilt or Stewart's disease of corn. The Canner, 56, 164-165.

PHYTOMONAS TUMEFACIENS (Smith and TOWnsend) Bergey et al.

(See Bacterium tumefaciens.)

Genus: Pseudomonas

PSEUDOMONAS AERUGINOSA (Schroster) Migula (See Bacillus pyocyaneus. )

PSEUDOMONAS FERMENTANS VOn Wolzogen Kuhr (See Flavobacterium fermentans.)

PSEUDOMONAS FLUORESCENS MigULa (See Pseudomonas fluorescens liquefaciens.) 


\section{PSEUDOMONAS FLUORESCENS LIQUEFACIENS}

Insect concerned: The honey bee, Apis mellifera.

White (1906) isolated Pseudomonas fluorescens liquefaciens from the intestine of the normal honey bee.

This organism is most likely Pseudomonas fluorescens. (See Bergey Manual, 5th ed., p. 129.)

White, G. F. 1906 The bacteria of the apiary, with special reference to bee diseases. U. S. Dept. Agri. Bull. No. 14, Bur. Entomol., $50 \mathrm{pp}$.

\section{PSEUDOMONAS OVALIS Chester}

Insect concerned: The Colorado potato beetle, Leptinotarsa decemlineata.

Steinhaus (1940) found this bacterium in the alimentary canal of the larvae of the Colorado potato beetle. This organism is frequently. found in the soil and hence may easily become associated with this insect. A description of Pseudomonas ovalis may be found in Bergey's Manual ( 5 th ed., page 133).

Steinhaus, E. A. 1941 A study of the bacteria associated with thirty species of insects. J. Bact., 42, 757-790.

\section{PSEUDOMONAS SALICIPERDA LINdeijer (See Phytomonas saliciperda.)}

\section{PSEUDOMONAS SEPTICA Bergey et al.}

Insects concerned: Euxoa segetum Schiff.; the firefly, Photinus pyralis; and in the potato beetle, Leptinotarsa decemlineata.

Stutzer and Wsorow (1927) isolated from Euxoa segetum an organism which they named Bacillus fluorescens septicus. They thought it was one of two agents that caused a "spring disease" among the caterpillars in 1925. Experimentally they were able to produce the disease by infecting the insects through the damaged integument. Thus, it was thought that the infection was brought about in a similar manner when the caterpillars were in the earth. 
Steinhaus (1941) found an organism similar to Pseudomonas septica in normal fireflies and potato beetles. It was the only organism he cultured from both the alimentary tract and ground-up specimens of the firefly. It also occurred in the alimentary tract of the potato beetle.

See Bergey's Manual, 5th ed., p. 130, for a complete description.

Steinhaus, E. A. 1941 A study of the bacteria associated with thirty species of insects. J. Bact., 42, 757-790. Stutzer, W. J. and Wsorow, M. J. 1927 Cent. f. Bakt., II Abt., 71, 113

\section{Tribe: SPIRILLEAE}

Genus: Vibrio

\section{VIBRIO COMMA (Schroeter) Bergey et al.}

Insects concerned: The house fly, Musca domestica; the blue bottle fly, Calliphora vomitoria; the sewer fly, Eristalis tenax; and cockroaches.

The specific relationship of Vibrio comma to cholera was discovered by Robert Koch in 1883, when he isolated the organism from the intestinal contents of cholera patients. Two years later Maddox (1885) claimed to have found the cholera organisms in the feces of Eristalis tenax and Calliphora vomitoria after having fed the flies on cultures of the vibrios. During the following 25 years several investigators conducted similar experiments and in nearly every case they found the bacteria to be taken up by flies (including Musca domestica). Graham-Smith (1910) found that flies fed on old laboratory cultures passed infected feces for 30 hours. However, the bacteria soon died on the legs and wings and that after 48 hours cultures made from the intestines of the flies were negative. For a discussion of other early experiments on flies as vectors of cholera see Howard (1911) and GrahamSmith (1913).

necording to Herms (1939), Gill and Lal in 1931, found evidence that posibibly one phase of the life cycle of the cholera vibrio is passed in the body of the house fly. According to these workers, the bacteria disappear from the body of the fly after approximately 24 hours but reappear about the fifth day when the fly is capable of contaminating 
food with its feces. This work, however, has not been definitely confirmed by other workers.

Barber (1914) and Toda (1923) have shown that cockroaches may be a factor in the spread of cholera.

A description of Vibrio comma may be found in Bergey's Manual (1939, 5th ed., page $\overline{105)}$.

Barber, M. A. 1914 Cockroaches and ants as carriers of the vibrio of Asiatic cholera. Philippine J. Sci., Sec. B., 9, 1-4.

Graham-Smith, G. S. 1910 Observations on ways in which artificially infected flies (Musca domestica) carry and distribute pathogenic and other bacteria. Repts. to the Local Govern. Board on Pub. Health and Med. Subjects, New Series, No. 40, 1-40.

Graham-Smith, G. S. 1913 Flies in relation to disease. 292 pp., Cambridge University Press, Cambridge.

Herms, W. B. 1939 Medical entomology. 3d ed., 582 pp. MacMillan Company, New York.

Howard, L. O. 1911 The house fly; disease carrier. 3d ed., 312 pp. Frederick A. Stockes Co., New York.

Maddox, R. L. 1885 Experiments on feeding some insects with the curved or "comma" bacillus, and also with another bacillus (subtilis?). J. Roy. Microsc. Soc., Ser. 2, 5, 602-607, 941-952.

Toda, T. 1923 Cholera and the ship cockroach. J. Hyg., 21, 359-361.

\section{VIBRIO LEONARDI Metalnikov and Chorine}

Insects concerned: The bee moth, Galleria mellonella; the corn borer, Pyrausta nubilalis.

Metalnikov and Chorine (1927, 1928) isolated Vibrio leonardi from diseased corn borer larvae, and found it to be very pathogenic to both corn borer larvae and bee moth larvae. They found the insects very susceptible to infection by mouth, dying within 24 hours.

These workers have given a description of the organism (1927), and one may also be found in Bergey's. Manual, 5th ed., 1929, p. 111 .

* Metalnikor, S. and Chorine, V. 1927 The infectious diseases of Pyrausta nubilalis $\mathrm{Hb}$. Internat. Corn Borer Invest., Sci. Rpts., I, 41-69.

* Metalnikov, S. and Chorine, $\overline{\mathrm{V}}$. 1928 Maladies bactériennes chenilles de la pyrale du mais. (Pyrausta nubilalis Hb.). Compt. rend. acad. sci. Fr. 186, 546-549. 


\section{$\underline{V I B R I O}$ PIERIS}

Insect concerned: Pieris brassicae.

Paillot (1933) refers to this organism as having been frequently encountered in the caterpillars of Pieris brassicae which had been parasitized by larvae of Apanteles glomeratus.

Paillot, A. 1933 L'infection chez les insects, 535 pp. Imprimerie de Trevoux, Paris. (See p. 134.)

\section{Family: RHIZOB IACEAE}

Genus: Alcaligenes

\section{ALCALIGENES AMMON IAGENES Castellani and Chalmers}

Associated insects: The imperial moth, Eacles imperialis; the blister beetle, Epicauta pennsylvanica; and Urographus fasciata.

Bacteria very similar to Alcaligenes ammoniagenes were found in the above-listed insects by Steinhaus (1941). For a description of the organism see Bergey's Manual (1939, 5th ed., page 99).

Steinhaus, E. A. 1941 A study of the bacteria associated with thirty species of insects. J. Bact., 42, 757-790.

\section{ALCALIGINES STEVENSAE BrOWn}

Insect concerned: Malacasoma americana.

Brown (1927) isolated this organism from crushed egg masses of the moth, Malacosoma americana F. According to Brown, the organism is probably allied to Alcaligines bronchisepticus. He has given a complete description of the organism.

* Brown, F. M. 1927 Description of new bacteria in insects. Am. Mus. Novit., No. 251, 11 pp. 
Genus: Chromobacterium

CHROMOBACTERIUM VIOLACEUM (Sciroeter) Bergonzini

Insect concerned: The roach, Periplaneta orientalis.

Longfellow (1913) was able to cultivate Bacillus violaceus $[$ Chromobacterium violaceum $]$ from the feces of the Longfellow, R. C. 1913 The common house roach as a carrier of disease. Am. J. Public Health, 3, 58-61. 


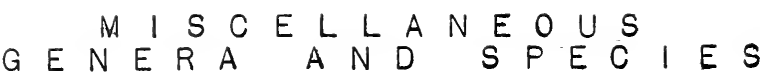

\section{ASCOBACTERIUM LUTEUM Babes}

Insect concerned: The olive fly, Dacus oleae.

Petri (1910) found Ascobacterium lutem in the intestinal tract of the larva of the olive fly. He suggested that the presence of the bacteria might be quite favorable for the digestion of the olive oil since Dacus oleae larvae bore into olives and necessarily ingest very large quantities of oil. This may be especially true of Ascobacterium lutem which is found in large numbers of larvae living on ripe and therefore oily fruit.

Just what organism Petri refers to would be hard to judge. There is a Bacteridium luteum which was described about 1872, and is commonly found in air and water (see Bergey's Manual, 5th ed., 1939, p. 240) and is now known as Micrococcus luteus. Also there is a Bacterium lutem which Adametz described in 1885, and isolated from the stomach contents of sheep and from water. (See Bergey's Manual, 5th ed., 1939, p. 633). Apparently, however, these have no relation to the organism which Petri isolated.

Petri, I. 1910 Untersuchungen Hber die Darmbakterien der Oliven feiege. Centralbl. Bakt., Par. Inf., II, 26, $357-376$.

\section{COCCOBACILLUS ACRIDIORUM d'Herelle}

Insects concerned: Schistocerca americana; Schistocerca peregrina; Schistocerca paranensis; Melanoplus femurrubrum; Melanoplus bivittatus; Melanoplus atlantis; Tmetis muricatus; Oedalens nigrofaciatus; Arcyptera flavicosta; Pachytylus (Locusta) migratoroides; Atta sexdens; Dociostaurus maroccanus, Pezomachus botrana; stauronotus maroccanus; Solenopsis gemminata; Bombyx mori; Zonocerus elegans; Caloptenus sp.; Tropidacris dux.

Coccobacillus acridiorum was first isolated by d'Herelle (1911) in Yucatan, Mexico, from a species of locust, Schistocerca americana Drury. While in Mexico, d'Herelle noticed a heavy mortality occurring in the destructive South American migratory locust which had arrived from the borders of Guatemala. From 1909 to 1911 the epizootic 
occurred so extensively that by 1912 it had reduced the number of locusts to such an extent that no invasion into Mexico occurred. D'Herelle succeeded in isolating the bacterium responsible for the epizootic from the intestinal contents of dead locusts, the same organism not occurring in healthy specimens. D'Herelle found further that locusts artificially inoculated with this organism died with the characteristic symptoms. However, Mereshkovsky (1925), Pospolov (1926) and others have expressed the belief that Coccobacillus acridiorum is a normal "symbiont" of the blood of locusts, which can, under certain conditions of temperature and humidity, become a dangerous parasite.

Coccobacillus acridiorum is a pleomorphic bacillus with coccoid forms ( 0.4 to $0.6 \mathrm{microns})$ and bacillary forms ( 0.9 to 1.5 microns) appearing in the same culture. In young cultures and in the intestinal contents of the locust the coccoid forms are the most abundant. Many cultures have been considered to be Coccobacillus acridiorum when in reality they were, not. This has been brought out by Glaser (1918) in a systematic study of the organisms placed under the name of Coccobacillus acridiorum d'Herelle.

Since d'Herelle's early successes some investigators have been able to confirm his results while others have not. For one thing, there seems to be a difference in susceptibility of different locusts to the disease. The bacteria appear to be more effective against locusts belonging to the genus Schistocerca than against other genera of the Locustidae. Species of the genus Caloptenus in Argentina and Stauronotus maroccanus in Algeria have been found to be experimentally susceptible. D'Herelle apparently was successful in combating plagues of Schistocerca paranensis in Argentina. In 1915 d'Herelle controlled an outbreak of Schistocerca peregrina in Tunisia by a combination of mechanical methods and the use of his organism. Experimentally the organism was found to be pathogenic for Schistocerca paranensis and Tropidacris dux in Trinidad (Rorer, 1915). Glaser (1918) found that a certain strain of Coccobacillus acridiorum ("Souche cham") was pathogenic to Melanoplus atlantis, and to Melanoplus bivittatus and Melanoplus femurrubrum to a lesser degree. Another strain ("Souche Sidi") was less pathogenic to Melanoplus atlantis and Melanoplus bivittatus than the "Souche Cham" strain.

Among the insects which were slightly or not at all susceptible to wholesale destruction by Coccobacillus acridiorum are: Pachytylus (Locusta) migratoroides (Mackie, 1913), Zonocerus elegans (Lounsbury, 1913), and 0edalens nigrofasciatus (Barber and Jones, 1913). 
Among other insects susceptible to this bacterium are several species of ants and crickets. Fowls, guinea pigs, rabbits, cows, sheep, and man are refractory to infection, but the sewer rat dies in 3-4 days after a subcutaneous inoculation with Coccobacillus acridiorum.

Barber, M. A., and Jones, O. R. 1913 A test of Coccobacillus acridiorum d'Herelle on locusts in the Philippines. Phil. Is. Sc., 10, Ser. B.

Glaser, R. W. 1918 A systematic study of the organisms distributed under the name of Coccobacillus acridiorum

d'Herelle. Ann. Entomol. Soc. Amer., 11, 19-42. *d'Herelle, F. 1911 Sur une epizootie de Nature Bacterienne sevissant sur les Sauterelles an Mexique.

Compt. rend. acad. sci., 152, 1413.

d'Herelle, F. 1915 Sur le procédé biologique de destruction des Sauterelles. Compt. rend. acad. sci., 161, 503.

Lounsbury, C. P. 1913 Locust bacterial disease. Agr. J. Un. S. Africa, 5, 607-611.

Mackie, D. B. 1913 Philipp. Agric. Rev., 6, 538. Mereshkovsky, S. 1925 Ann. State Inst. Exp. Agron., Leningr., 3,7 .

Pospelov, V. P. 1926 The influence of temperature on

the maturation and general health of Locusta migratoria,

L. Bull. Entomol. Research, 16, 363-367.

Rorer, J. B. 1915 Report on the inoculation of Locusts

with Coccobacillus acridiorum. Bull Dept. Agric.,

Trinidad and Tobago, Port of Spain, 14, No. 6, 197-198.

\section{COCCOBACILLUS CAJAE Picard and Blanc}

Insects concerned: Arctia caja; Poecilus koyi; Epacromia strepens; the oriental roach, Periplaneta orientalis; Eurydema ornata; Cleonus mendicus; Chrysomela sanguinolenta; Anoxia australis; Melolontha vulgaris; Opartum sabulosum; Cretonia aurata; Porthesia chrysorrhoea; the silkworm, Bombyx mori; Acridium aegyptium Hydrophilus; Dystiscus; Cybister; Notonecta; Nepa; Ranatra.

The caterpillars of Arctia caja L., which were extremely abundant in the vineyards of Southern France, were almost completely wiped out by two diseases. One disease was caused by the fungus, Empusa aulicae, the other by a bacterium, Coccobacillus cajae. The organism, which is apparently allied to coccobacillus acridiorum d'Herelle, was obtained by Picard and Blanc (1913a) from the blood of diseased caterpillars and the disease was experimentally reproduced. 
Coccobacillus cajae is motile, gram-negative, and shows bi-polar staining. Unlike Coccobacillus acridiorum, it is a parasite of the blood of the caterpillar and not of the digestive tube. When caterpillars are given by ingestion a few drops of a culture by means of a pipette introduced into the pharynx, they die after a few hours from a septicemia.

Besides the larvae of Arctia caja, Picard and Blanc (1913b) found Coccobacillus cajae to be pathogenic to the following insects: Coleoptera: Poecilus koyi, Opatrum sabulosum, Cetonia aurata, Melolontha vulgaris, Anoxis australis, Chrysomela sanguinolenta, Cleonus mendicus; Hemiptera: Eurydema ornata; Orthoptera: Periplaneta orientalis, Epacromia strepens, Acridium aegyptium; Lepidoptera: Porthesia chrysorrhoea, and Bombyx mori. According to Picard and Blanc, this list could probably be extended indefinitely since it is probable that the majority of insects are killed by Coccobacillus cajae. It is interesting to note, 'however, that the aquatic beetles are among those which are immune: Coleoptera: Hydrophilus, Dystiscus, Cybister; Hemiptera: Notonecta, Nepa, and Ranatra. While the white rat is immune, the tree frog, Hyla arborea, dies of septicemia in about two days, its blood containing numerous Coccobacilli.

Various workers have referred to this bacterium as "Bacillus cajae" (Marchal, 1914; Picard, 1914; Paillot, 1933).

Marchall, P. 1914 Rapport phytopathologique pour I'annie 1913. Rev. Phytopath. App., Nos. 18-19, pp. 9-13. Paillot, A. 1933 L'infectious chez les paris insectes, 533 pp. Imprimerie de Trevoux., (see page 125). * Picard, F., and Blanc, G. R. I9l3a Sur une septicemie bacillaire des chenilles d'Arctia caja, L. Compt. rend. acad. sci., 156, 1334-1336.

Picard, F., and Blanc, G. R. 1913b Les infections a coccobacilles chez les insectes. Compt. rend. hebd. acad. sci., 157, 79-81.

Picard, F., and Blanc, G. R. 1914 Les Chelonies on Chenilles baurrues. progrếs Agric. Vitic., 31, 261-266.

COCCOBACILLUS ELLINGERI MetalnikOV and Chorine (See also Escherichia ellingeri.)

Insects concerned: The European corn borer, Pyrausta nubilalis; the bee moth, Galleria mellonella; and Ceratitis capitata. 
This organism was first isolated in November, 1927 by Metalnikov and Chorine (1928) who found it repeatedly in diseased corn borers. Larvae of Pyrausta nubilalis and Galleria mellonella, inoculated with a "tiny dose" of Coccobacillus ellingeri died in the course of 2 to 12 hours. Corn borer larvae were very susceptible to infection through the intestinal tract, the bacteria passing through the wall of the intestine into the blood where they were found in great numbers. The bacterium has no pathogenic effect on guinea pigs or rabbits.

According to its discoverers, "Coccobacillus ellingeri somewhat resembles Bacterium sphingidis White, Bacterium noctuarum White, and Bacterium melolonthae liquefaciens alpha Paillot. It differs, however, from these three species by being non-motile. There are also other minor differences."

Citrus fruits infested by Ceratitis capitata in Sicily were found by Ciferri (1934) to be "infected" by a bacterium, apparently Escherichia (Coccobacillus) ellingeri. It appeared to be a "symbiont" but could become pathogenic to the larva under certain conditions.

In the 3d edition of Bergey's Manual (1930, p. 330) this organism is referred to as Escherichia ellingeri Bergey et al. However, in the $5 \overline{\text { th edition }}(1939$, p. 606) it was designated by its original name, Coccobacillus ellingeri.

Ciferri, R. 1934 Associazione tra larve della Mosca delle frutta (Ceratitis capitata) en un coccobacillo (Escherichia ellingeri). Lav. R. Ist. bot. Palermo., $4,168-200$.

* Metalnikor, S., and Chorine, V. 1928 The infectious diseases of Pyrausta nubilalis $\mathrm{Hb}$. Inter. Corn Borer Invest., Sci. Repts. $\frac{1}{1,41-69}$.

\section{COCCOBACILLUS GIBSONI Chorine (See also Bacillus gibsoni.)}

Insect concerned: The corn borer, Pyrausta nubilalis.

Chorine (1929a and b) isolated this bacterium from sick corn borer larvae which he had received from Canada. He described this organism as being very polymorphous, motile, non-spore-forming, gram-negative bacterium. The organism was extremely virulent for the corn borer larvae. The borers could be infected by injection and per os. Chorine (1929a) gave a complete description of the organism. 
*Chorine, V. 1929a New bacteria pathogenic to the larvae of Pyrausta nubilalis. Internat. Corn Borer Invest., Sci. Repts., 2, 39-53. * Chorine, V. 1929b Nouveaux microbes pathogenes pour les chenilles de la Pyrale du Mais. Ann. Inst. Pasteur, 43, 1657-1678.

\section{COCCOBAC!LLUS INSECTORUM VAR. MALACOSOMAE} Hollande and Vernier

Insects concerned: Malacosoma castrensis; Malacosoma neustria and Vanessa urticae.

Hollande and Vernier (1920) found the blood of 50 per cent of the caterpillars of Malacosoma castrensis examined to be infected with a new organism which they named Coccobacillus insectorum var. malacosomae.

*Hollande, A. C., and Vernier, P. 1920 Coccobacillus insectorum, n. sp., variété malacosomae, bacille pathogene, du Sang. de la Chenille Malacosoma castrensis, L. Compt. rend. hebdom. acad. sci., 171, 206-208.

\section{COCCOBACILLUS LYMANTRIAE Picard and Blanc} (See also Bacillus lymantriae and Diplococcus lymantriae.)

Insect concerned: The gypsy moth, Lymantria dispar.

Picard and Blanc (1913) discovered, in the caterpillars of the gypsy moth, a fatal septicemia due to an organism they named Coccobacillus lymantriae. It is difficult to determine whether Bacillus (Bacterium) Iymantriae, as mentioned by Paillot (1917, 1933), is a synonym for Coccobacillus lymantriae, but it is probable that they are the same. The latter is not a spore-former, hence the generic name Bacillus would not be appropriate according to present-day nomenclature.

Paillot, A. 1917 Microbes nouveaux parasites des chenilles de Lymantria dispar. Compt. rend. hebdom. acad. sci., $1 \frac{164}{933} 525-527$.

Paillot, A. $1 \overline{933}$ L'infections chez les insectes. $535 \mathrm{pp}$. Imprimerie de Trevoux, Paris. (See page 125.) *Picard, F., and Blanc, G. R. 1913 Les infections á coccobacilles chez les insectes. Compt. rend. hebdom. acad. sci., 157, 79-81. 
Insects concerned: The cockchafer, Melolontha melolontha; the gypsy moth, Porthetria (Lymantria) dispar; Vanessa urticae.

Diplobacillus melolonthae was isolated by Paillot (1917) from the larvae of the cockchafers.

* Paillot, A. 1917 Microbes nouveaux, parasites du Hanneton. Action pathogene sur chenilles de Vanessa urticae, Lymantria dispar et sur Vers a soie. C. R. Soc. biol., Paris, $80,56$.

Paillot, $\bar{A} .1933$ L'infection chez les insectes. $535 \mathrm{pp}$. Imprimerie de Trevoux, Paris. (See p. 299.)

\section{DIPLOBACILLUS PIERIS Paillot}

Insect concerned: The cabbage white butterfly, Pieris brassicae.

Paillot (1919) isolated Diplobacillus pieris from the larvae of diseased white cabbage butterflies. From the same source, he isolated 8 other bacteria. (See Bacillus pieris fluorescens.) He considered these bacteria to be secondary invaders, the parasite, Apantelles glomeratus, being the predisposing factor in the bacterial infection of the white cabbage butterfly.

*Paillot, A. 1919 Compt. rend. Acad. Sci., 168, 476.

\section{DANYSZ BACILLUS}

Insect concerned: The bee moth, Galleria mellonella.

Huff (1940) refers to the work of Zernoff in which he used heated Danysz bacilli to produce an immunity in the bee moth.

This organism is the same as Salmonella enteritidis.

Huff, Clay G. 1940 Immunity in Invertebrates. Physio. Rev., 20, 68-88. (See p. 73.) 
ENTEROBAC ILLUS LARVAE Stutzer and Wsorow (See Achromobacter larvae.)

Insect concerned: Euxoa segetum.

Stutzer and Wsorow (1927) isolated Enterobacillus larvae from the intestinal tract of normal larvae.

Achromobacter larvae (Stutzer and Wsorow) Bergey et al. is the now accepted name for Enterobacillus larvae. Tsee Bergey's Manual, 1939, 5th ed., p. 517.)

Stutzer, M. J. and Wsorow, W. J. 1927 Uber Infectionen der Raupen der Wintersaateule (Euxoa segetum Schiff.) Cent. f. Bakt. U. Parasitenk., $\overline{11}, 11 \overline{3-129 .}$

\section{ENTEROCOCCUS CITREUS Stutzer and Wsorow}

Insect concerned: Eluxoa segetum.

Stutzer and Wsorow (1927) isolated this organism from normal pupae of Euxoa segetum.

*Stutzer, M. J., and Wsorow, W. J. 1927 Uber Infectionen der Raupen der Wintersaateule (uxxoa segetum Schiff.)

Centr. f. Bakt. U. Parasit., 71, 113-129.

\section{GYROCOCCUS FLACCIDIFEX Glaser and Chapman}

Insect concerned: The gypsy moth, Lymantria dispar.

Glaser and Chapman (1912) isolated this organism from caterpillars of the gyasy moth during their studies on the cause and nature of the wilt disease occurring in this insect. These investigators originally believed that this organism was the cause of the wilt disease. It was later discovered, however, that nearly all of the insects used for experimentation had become "accidentally infected" with this bacterium. In 1913, Glaser and Chapman (see Glaser, 1928) corrected their mistake and showed it to be caused by a filterable virus.

Gyrococcus flaccidifex was described as a small (0.50.85 microns), gram-negative, encapsulated organism, resembling the pneumococcus more than any other form except that it was motile, progressing in a "gyrating" manner. It was from this latter characteristic that the generic name was derived. 
Glaser, R. 1928 In Rivers, T. M. "Filterable Viruses," $427 \mathrm{pp}$. Williams and Wilkins Co., Baltimore. Chapt. VIII. Virus diseases of insects, pp. $301-333$ (see page $308)$.

*Glaser, R. W., and Chapman, J. W. 1912 Studies on the wilt disease, or "flacheria" of the gypsy moth. Science, 36, 219-224.

\section{LEPTOTRIX BUCCALIS}

Insect concerned: The mosquito, Anopheles maculipennis.

According to Keilin (1921), who quoted Howard, Dyar and Knab (1912), Perroncito, in 1899, discovered a bacterial parasite of Anopheles maculipennis resembling "Leptotrix buccalis." "The parasite infests the larva, passes into the pupa, and destroys the imago soon after it emerges" (Keilin). From the information given, it is difficult to ascertain whether this organism is the same as the one now known as Leptotrichia buccalis.

Howard, L. O., Dyar, H. G., and Knab, F. 1912 The mosquitoes of North and Central America and the West Indies, I. Carnegie Institution, Washington. (Quoted by Keilin, 1921.)

Keilin, D. 1921 on a new type of fungus: Coleomomyces stegomyiae n. g., n. sp., parasitic in the body cavity of the larva of Stegomyia scutellaris Walker (Siptera, Nematocera, Culicidae). Parasitol., 13, 226-234.

Perroncito, E. 1899 Sopra una speciale forma di micosi delle Zanzare. Bolletino della R. Acad. di med. di Torino. (Not seen; taken from Keilin, 192l.)

\section{PNEUMOCOCCO}

Insect concerned: The flea, Pulex irritans.

Pinto (1930) lists this organism as being cultivated from the digestive tract of Pulex irritans by da Silva (1916). Presumably the pneumococcus (Diplococcus pneumoniae) is meant but since the original article was not available, this could not be ascertained.

Pinto, C. 1930 Arthropodes parasitos e transmissores de doencas. Vol. 1, $395 \mathrm{pp}$. (See page 367.)

Silva, Pereira da. 1916 Exper. sur la trans. de la leishmaniose infantile par les puces (Pulex irritans). In Arq. do Inst. Camara Pestana. 4, 26-27. (Not seen.) 
INDEX TO AUTHORS

Allen, 11, 25, 169

Andre, 38

Aoki, 84

Ark, 119

Arkwright, 74

Ascolese, 132

Atkin, 12, 16, 25

Atkinson, 71, 72

Babers, 51

Bacot, A., 7, 9, 12, 16, 25, 74,80

Baer, 23, 24, 26

Bahr, 73

Bandelli, 132

Barber, 6, 12, 16, 26, 175,

179,180

Baumberger, 18, 26

Benedek, 65

Bengtson, 91

Berliner, 87, 88

Bilal, 165, 166

Blanc, 52, 64, 137, 180, 181,183

Blynn, 7

Bogdanow, 17, 18, 26

Bollinger, 43

Bonde, 120, 121

Borzenkov, 161, 162

Bourne, 75

Bowers, 21, 26

Bozhenko, 165, 166

Breed, 57, 60, 123, 133,

134

Brooks, 165, 167

Brown, 19, 26, 61, 63, 127,

$146,152,158,176$

Buchanan, 168

Buchner, 170, 171

Burnside, 13, 26, 41, 42,

$73,77,92,93,139,140$

Burri, 48, 49

Burrill, 119, 147, 148

Burroughs, 86, 87, 146, 147, 152

Burrows, 113
Cahn, 125, 126

Cash, 122

Celli, 38

Chahovitch, 80

Chang, 131

Chapin, 163, 166

Chapman, 6, 2.6, 47, 66, $146,147,185,186$

Chatton, 66

Cheshire, 13, 26, 41, 42

Cheyne, 13, 26, 41, 42

Chigasaki, 84

Chittenden, 151, 152

Chorine, 50, 58, 72, 84, $88,95,97,99,100$,

107, 108, 110, 111,

$113,114,133,135$,

$145,175,182,183$

Chow, 124, 129, 130, 131, 132

Chun, 161, 162

Ciferri, 182

Clark, 42

Couvreur, 80

Cowan, 49

Cox, 7, 26

Cuboni, 53

Currie, 37

Darling, 129

Davis, 149, 164, 165, 166

Dean, 11, 26

DeBach, 2, 94, 106, 107, $132,133,134$

Delpy, 44

Descazeaux, 98

Donskov, 161, 162

Dougherty, 54, 117, 118

Duboscq, 54, 118

Dufrenoy, 109, 110, 143

Duggar , 55

Duncan, 6, 22, 23, 27,

$43,44,68,70,80$,

$86,87,133,134,142$,

$144,154,155,156$,

157 
DuPorte, 149, 150

Dutky, 62, 78

Dyar, 186

Dyson, 17, 27

Eckstein, 41, 45, 46, 50, $52,54,56,57,63,69$, $70,72,83,84,85,87$, $89,105,148,152$

Ellinger, 88, 99, 114

Elliott, 119, 121, 171

Engelhardt, 48

Ermolaev, 76, 96, 102, 103, 111

Eskey, 160, 162

Evans, 165, 166

Faddeeva, 161, 162

Faichnie, 129, 130

Ficker, 129, 130

Flegontoff, 165, 167

Forbes, 7, 27, 147, 148

Foster, R. E., 73

Francis, 163, 164, 166,

167

Frost, 21, 27

Gaisky, 161

Galli-Valerio, 155, 156

Garbini, 53

Gaschen, 128

Ghosal, 15, 28

Gier, 33, 35, 53

Gillette, 113

Gjullin, 12, 27

Glaser, 18, 19, 27, 33, .

$35,53,77,78,123$,

$141,142,146,147$,

$157,179,180,185,186$

Glasgow, 8, 27

Glynn, 26

Golov, 165,166

van der Goot, 58

Graham-Smith, 7, 27, 34, $38,44,129,130,174$,

175

Grasse, 54, 118

Green, 165, 166

Gunderson, 91
Guyenot, 27

Haas, 160,162

Hamilton, 129, 130

Hansen, G. A., 36

Hansen, H. N., 169

Hatcher, 41, 86, 87, 93, 151

Hauduroy, 73

Haushalter, 38，39

Heim, 44

d'Herelle, 178, 179, 180

Hering, 19, 27

Herms, 6, 21, 27, 43, 44, $154,155,156,174,175$

Hertig, 5, 27, 53

Hewitt, 7,27

Hindle, 22, 27, 44, 70, $86,87,155,156$

Hinman, 12, 13, 16, 28

Hitchcock, 120

Hobson, 21, 28

Hoelling, 117, 118

Hofmann, 38, 45, 46, 69,

70,105

Hollande, 183

Honei $j, 37$

Hoskins, 21, 27

Howard, L. 0., 129, 130, 186

Howard, W. R., 68, 69,

174,175

Huang, 131

Hucker, 139, 140, 142

Huddles on, 158, 159

Huff, 34, 184

Huie, 4

Husz, 87, 89

Imms, 21, 28

Ischivata, 84

Jackson, 6, 28

Jellison, 164

Jepson, 96

Johannsen, 37, 38, 39,

129,130

Johnson, D. E., 120,

121 
Johnston, 120

Jones, L. R., 120, 121

Jones, O. R., 179, 180

Jordan, 113

Kalinicker, 79, 80

Kamil, 165, 166

Kaweh, 44

Kelin, 186

King, 71,72

Kitajima, 100

Kitasato, 160, 162

Kluyver, 94, 106

Knab, 186

Koch, 43, 174

Kohls, 165, 166

Kolpakova, 165, 167

Kostritsky, 115

Krassilstschik, 83, 89,.143, 148

Ksenjoposky, 43

Kuffernath, 154

Kuhn, 43, 45

Kuskop，8，9，28

Lake, 164, 166

Lal, 15, 28

Larrey, 23

Leach, 7, 9, 10, 28, 119, $120,121,168,169,170$,

171,172

Lebert, 151

Lehmann, 57, 60, 1.23

Lepesme, 80, 133, 134

Lewis, 7,26

Leydig, 8, 28

Lien-teh, 161, 162

Lieu, 131

Lindeijer, 170

Livingston, 23, 28

Lloyd, 17, 27

Lochhead, 77

Longfellow, 6, 28, 34, 124, $128,133,134,155,156$,

177

Lounsbury, 179, 180

tuginbill, 149

Maassen, 13, 28, 41, 42, 139,140
Macalister, 25, 28

Macchiate, 47

Macfie, 37, 38, 129

MacGregor, 138

Mackie, 179, 180

Mackimmon, 56

MacLeod, 6

Maddox, 174, 175

Mallman, 163, 166

Marchal, 181

Marsh, 165, 167

Martinaglia, 44

Masera, 132, 133, 134, 135

Mattes, $40,60,87,88$, 146

Mayne, 163, 166

McCay, 21, 26

McCoy, 163, 166

McCray, 73

Mcomie, 2, 93, 106, 107, $132,133,134$

Melampy, 6, 28

Meng, 59, 101

Mercier, 53

Mereshkovsky, 179, 180

Metalnikov, S., 34, 38, 59,

$74,80,81,84,86,87$,

$91,96,99,100,101$,

$102,103,107,110,111$,

$112,113,114,115,128$,

$132,133,135,175,182$

Metalnikov, Jr., S., 34 , $38,59,74,76,100,101$, 110,112

Metchnikoff, 82

Miller, 17

Mitchell, 16, 28

Mitzmain, 43, 44

Morischila, 129

Morris, 43, 44

Mukherji, 15, 28

Munro, 125

Needham, N. Y., 61, 62

Nelson, 125

Neumann, 57, 60, 123

Nicoll, 7, 29

van Niel, 94, 106

Nieschulz, 43, 44, 45

Noble, 74 
Noguchi, 55, 79, 81

Northrup, 83, 149, 150, 151 Norwood, 6

Nuttall, 6, 23, 43

Ogata, 160, 162

Olsufiev, 165, 166, 167

Paccanaro, 140, 141

Paillot, 14, 29, 47, 50,

$53,58,59,63,64,65$,

$66,67,71,72,75,76$,

$79,81,82,84,104$,

$107,109,110,136,137$,

$138,140,141,143,149$,

$156,176,181,183,184$

Pammel, 168

Pari, 23

Parker, 11, 29, 37, 1.64, 165,167

Pasteur, 47

Patton, 97, 158, 159

Perroncito, 186

Petri, 10, 18, 29, 170,

171,178

Pfeiffer, 99, 102, 103

Philip, 164, 165, 167

Picard, 51, 52, 64, 137, $180,181,183$

Pierce, 39

Pinto, 186

Pollini, 132

Pollitzer, 161, 162

Ponce, 77

Portier, 19, 21, 29

Pospelov, 40, 47, 76, 133,

$135,179,180$

Prince, 23, 28

Proust, 44

Raimbert, 43

Rand, 122, 172

$\mathrm{Re}, 132$

Reynolds, 37, 38, 130, 134, 135, 155, 156

Rhoads, 17

Riker, 11, 25, 169

Riley, 37, 38, 39, 129, 130

Roberts, 82
Robinson, 6, 25, 29

Rorer, 179, 180

Rosenau, 36

Roubaud, 20, 29, 98

Rozebloom, 12, 16, 29

Rozier, 132

Ruhland, 158, 159

Sartirana, 140, 141

Sassuch in, 162

Saunders, 138, 139

Sawamura, 55, 56, 57, 65, $70,71,80,81,82,89$, $124,155,156$

Schaudinn, 49

Scheverdtfeger, 82, 83

Schuberg, 43, 45

Schutte, 20, 29

Scott, 159

Sheperd, 87, 89

Serbinow, 42, 48, 49, 68, 97, 126, 153

Shiperovich, 82,83

Shul'gina, 79, 80

Silva, 186

Simmons, J. S., 37, 38, $130,134,135,155,156$

Simmons, S. W., 19, 25, 29, 30

Simond, 160, 162

Skobaltzyn, 76, 96, 102, 103, 111

Smith; E. F., 122, 168, 171

Smith, R. C., 113, 148

Smith, R. E., 169

Smyth, E. G., 149, 150

Specht, 65

Spencer, 11, 29, 164, 167

Spielman, 38, 39

St. John, 37, 38, 130, $134,135,155,156$

Stage, 12, 27

Stammer, 6, 11, 18, 30, $99,102,103$

Statelov, 46

Steinhaus, 5, 15, 30, 34, $35,40,51,53,60,86$, 
$87,92,94,101,102,103$, $105,106,112,113,115$, $116,117,122,123,124$, $125,127,128,129,134$, $135,142,144,145,147$, $150,151,153,173,174$, 176

Stewart, 24

Stutzer, 93, 94, 108, 109, 115, 122, 153, 173, 174, 185

Sweetman, 45, 48, 111,112

Tarr, 42

Tatum, 21, 22, 30

Tauber, 154, 155

Tebbutt, 39, 90

Te jera, 38, 39

Thomas, 119, 125, 126

Thorpe, 6, 30

Tichomirova, 162

Toda, 175

Torrey, 7, 30, 147

Toumanoff, 115

Trager, 17, 30

Tsuchimochi, 129

von Tubeuf, 46, 69, 70, 105

Vasco, 132

Vedder, 37

Vernier, 183

Volferz, 165, 167

Wahl, 105, 106

Waite, 119, 120
Wallace, 126

Waller, 165, 167

Wardle, 137, 138, 140, 141

Weinland, 17, 18, 19, 30

Werner, 19, 20, 30, 91, 92

Wharton, 77

Wheeler, 129, 130

White, 5, 13, 30, 31, 39, $41,42,46,48,49,51$,

$54,57,61,62,68,69$,

$70,71,72,73,74,77$,

$85,86,87,89,90,92$,

93, 95, 98, 106, 123, $124,131,144,173$

Wigglesworth, 20, 21, 31

Wollman, 17, 18, 19, 31

von Wolzogen Kuhr, 17, 31, 116

Wsorow, 93, 94, 108, 109, $115,122,153,173,174$, 185

Wu, 161, 162

Yao, 4, 31

Yates, 12, 27

Yersin, 160, 161

Yuan, 4

Zasukhin, 165, 167

Zernhoff, 133, 135

Zorin, 42

Zorina, 42 
acutus (Ceratophyllus) 160, 161,163

aegypti (Aedes) [Stegomia] fasciata 12, 13, 16, 17, $25,30,36,37,38,129$, $130,132,134,135,155$, $156,160,163,165$ aegyptium (Acridium) 180, 181 agrestis (Agriolimax) 168 agrestis (Tabanus) 163 Agrotis sp. 101 agyrtes (Ctenophthalmus) 160 albipennis (Bibio) 118 albipictus (Dermacentor) 125, 163

aldrichi (Aedes) 12 Allorrhina spp., 149 americana (Malacosoma) 61, 149,176 americana (Periplaneta) 33, 35, 36, 38, 41, 93, 129, $149,151,158$ americana (Schistocerca) 178 americanum (Amblyomma) 163, 164 amplipennis (Isophya [Barbitistes]) 46 andersoni (Dermacentor) 11, 29, 30, 55, 79, 81, 132, $134,163,164,167$ angusticollis (Zootermopsis) 94, 106, 132, 133 anisus (Monophyllus [Ceratophyllus]) 160

annexa (Feltia) 71 Anthrenus sp. 118 antiqua (Hylemyia) 118 Ants, 129, 130 anxia (Phyllophaga) 78 apicalis (Culex) 163, 165,

166

arboricola (Strigoderma) 78 archippus (Danais) 146 assimilis (Ctenophthalmus)

163

assimilis (Muscina) 118 astia (Xenopsylla) 160, 161 atlantis (Melanoplus) 178, 179

atra (Orsodacne) 118 aurata (Cretonia) 180, 181 auriflua (Liparis) 45 auriflua (Porthesia) 63,

69,83

australis (Anoxia) 180, 181 austriaca (Anisoplia) 82 autumnalis (Ixodes) 160, 161 autumnalis (Tabanus) 163 avenae (Aphis) 118

barbata (Sarcophage) 36, 37 bifurcatus (Anopheles) 22 , 154, 155

bipartita (Phyllophaga) 78 bivittatus (Melanoplus) 113, 178,179

borealis (Cyclocephala) 78 botrana (Pezomachus) 178 brasiliensis (Xenopsylla) 160,161

brassicae (Hylemyia) 10, 120

brassicae (Pieris) 14, 69, $75,76,79,83,87,109$, $111,138,152,176,184$ brassicae (Plusia) 168 bromius (Tabanus) 163 brunnea (Serica) 96

cadaverina (Cynomyia) 118 caesar (Lucilia) 24, 90, 91 caja (Arctia [Chelonia]) 52,

59, 180, 181 calcitrans (Stomoxys) 22,

$23,36,37,43,44,68$, $70,80,86,98,132,133$, $154,155,158,160,163$, 166

calicrura (Hylemyia) 28 californicus, ricinus

(Ixodes) 163, 165, 166 Caloptenus sp., 178, 179 calopus (Aldes) 25 
calyptrata (Pegomyia) 118 campodeiformis campodeiformis (Grylloblata) 86, 87, 146, 147,152

canadensis (Ä̈des) 163, 165 canella var. gilvipes (Paria) 124,125

canis (Ctenocephalides) 160 capitata (Ceratitis) 181, 182 cardui (Pyrameis) 81 caspius (Al̈des) 163 castanea (Autoserica) 78 castrensis (Malacosoma) 183 catalpae (Ceratomia) 60, 85, 86, 117 cecropia (Platysamia) 51,

$86,124,125$ cementarium (Sceliphron) 105 Chalifora sp. 158

cheopis (Xenopsylla) 160, 161 Chrysomelidae sp., 86, 102 chrysorrhoea (Euproctis) 14,

$59,64,65,67,104,109$, 136

chrysorrhoea (Porthesia)

180,181

cilicrura (Hylemyia) 7, 9, 120

cinerea var. marginata

(Epicauta) 123

cinereus (Ä̈des) 22, 154, 155 citelli (Linognathoides) 160 citri (Pseudococcus) 132, 133 Coccinellidae sp. 115 Coenagrionidae sp., 150 columbianus (Haematopinus) 160 compressus (Adoretus) 58 configurata (Barathra) 125 confusum (Tribolium) 6, 26 conura (Tephritis) 6 convergens (Hippodamia) 118 cooleyi (Chermes) 169 corni (Lecanium) 65 cornutus (Echnocerus) 87, 89 costata (Elachiptera) 120 crataegi (Aporia) 95, 111, 114 Cryptocercus, 18 cunea (Hyhantria) 142 cuniculi (Spilopsyllus) 163,165 cuprea (Potosia) 19, 30, 91,92

Curculionidae, 86 Cybister sp., 180, 181 cytus basalis (Poecilo) 118

dauricus (Necrophorus) 160 decemlineata (Leptinotarsa)

$62,92,115,122,171,173$ decoloratus (Boophilus) 43, 44

decorum katmai (Simulium) 163,164

Demodex sp. 36 denticulata (Chaetocnema)

172

depressa (Lipoptena) 30 diadema (Sinea) 86 discalis (Chrysops) 163, 164,166

dispar (Lymantria [Porthetria ]) 14, 46, 59, 63, $64,65,66,67,87,95$, 104, 109, 111, 132, 136, $137,141,183,184,185$ domestica (Musca) 6, 7, 9, $15,17,22,29,33,34$, $36,37,38,39,63,80$, $90,97,98,118,119$, $129,132,138,139,147$, $154,155,157,158,159$, $160,174,175$

Dorcus, 20 dorsalis (Aldes) 163, 165 Drosophila, 21, 22, 118, 119, 120 ducens (Feltia) 71 duodecimpunctata (Diabrotica) 121, 172 dux (Tropidacris) 178, 179 Dystiscus sp., 180, 181

egyptium (Acridium) See: aegyptium (Acridium) elegans (Zonocerus) 178, 179 
ephemeraeformis (Thyridop-

teryx) 35, 103, 142, 147 ephilida (Phyllophaga) 78 erberi (Tabanus) 163 eridanis (Prodenia) 51 erythrocephala (Calliphora) 34,43

Euxoa spp. (Noctuidae) 71 evonymella (Hyponomenta)

$69,72,85$

fasciata (Stegomia) See: aegypti (Aedes)

fasciata (Urographus) 94 , 122,176

fasciatus (Glischrochielus)

118

fasciatus (Nosopsyllus

[Ceratophyllus ]) 160, 161 fasciatus (Oncopeltus) 5 , $127,128,132,134,142$ fasciatus var. fasciatus

(Conocephalus) 86, 115, 122,128

fasciatus var. fasciatus

(Neombius) 122, 124, 128, 135

felis (Ctenocephalides) 160

femoralis (Heliothrips) 168

femorata (Diapheromera) 101, 117

femur-rubrum (Melanoplus)

77, 113, 178, 179

flavicosta (Arcyptera). 178 flavidissimalis (Mimorista)

120

flavoguttatus (Tabanus) 163 flavosparsus (Orthotylus)

118

floricola (Cetonia) 96 funebris (Drosophila) 118 fusca (Lachnosterna) 55 fusca (Phyllophaga) 78 fusca var. subsericea

(Formica) 118

fusiceps (Phorbia) 120, 121 gallinae (Ceratophyllus) 160

Gamasidae, 163

gemminata (Solenopsis) 178 germanica (Blattella) 2l,

$31,33,35,123,124,142$, 154,155

gossypiella (Pectinophora)

74,99

gossypiella (Platyedra

[Gelechia]) 74, 100, 101, 110,112 graminum (Scaptomyza) 120 gregaria (Schistocera) 80, $132,133,134$ grissela (Achraca) 38 gryllotalpa (Gryllotalpa) 59,101

hamiltoni (Enochrus) 90, 91 heiseri (Tephritis) 11 hermsi (Ornithodoros) 163 Hippelates flies, 138, 139 histrionica (Murgantia) 8 humanus (Pediculus) 74 Hydrophilus sp., 180, 181 Hyponomenta sp., 148 hyrcanus (Anopheles) 163

imparis (Prenolepis) 118 imperialis (Eacles) 102, 150,176 incidens (Theobaldia) 27 , 163,165 iridipennis (Glyptotermes)

Calotermes 54, 117, 118 irritans (Haematobia) 43 irritans (Pulex) 160, 186

japonica (Popillia) 62, 78 junctoliniella (Olyca) 120

karybenthinus (Tabanus) 163 katmai, decorum (Simulium) 163,164

koyi (Poecilus) 180, 181 kthniella (Ephestia) 40, 87, 88, 89, 95, 99, 108, 111, 114,145 
Lachnosterna spp., 149, 150 laeviusculus (Neohaematopinus) 163,164

lahorensis (Ornithodoros) 163,165

lanestris (Eriogaster) 136 lapathi (Cryptorrhynchus)

$$
170
$$

lectularius (Cimex) 6, 22, 34, $36,43,45,68,70,86,113$, $145,153,155,163,166$ leporis-palustris (Haemaphysalis) 163, 164, 165

leprae (Chlorops [Musca]) 36 leucopterus (Blissus) 55, 147 Lice, 131,137

lineata (Deilephila) 55

Iineatum (Hypoderma) 19, 30 linnei (Tibicen) 15, 103, $106,142,1.50$

lipsia (Hylemyia) 118

litura (Prodenia) 74, 100,

110,112

livens (Hydromyza) 20

longicornis (Diabrotica) 172 Lucilia sp., 19, 21, 36, 158 lypusus (Dinopsyllus) 160 , 161

maculipennis (Anopheles) 186 malella (Nepticula) 19

mali (Empoasca) 118 mancus (Agriotes) 6, 28 maroccanus (Dociostaurus)

178

maroccanus (Stauronotus) 178, 179

megacephala (Chrysomyia)

$124,129,130,131,132$ melanogaster (Drosophilia) 118,119

mellifera (Apis) 39, 41, $43,45,46,48,49,51$, $54,57,60,68,70,72$, $73,77,85,90,92,95$, -97, 98, 106, 107, 123, $124,126,130,138,139$, $142,144,153,155,156$, 173 mellonella (Galleria) 18,

$33,34,38,80,86,91$,

$95,99,100,108,115$,

$127,132,133,135,145$,

$175,181,182,184$

melolontha (Melolontha) 59,

$66,67,83,89,104,137$,

149,184

mendicus (Cleonus) 51, 180, 181

mendicus (Conorrhynchus) 51 mendicus (Temnorrhinus) 51,

52

migratoria (Locusta) 79, 180 migratoroides (Pachytylus

[Locusta]) 178, 179 molitor (Tenebrio) 99, 101, $103,132,133$

monacha (Lymantria Liparis ) $41,45,46,50,52,63$, $69,70,83,85,87,89$, 105,148

Moneilema spp., 120

montanus (Diamanus) [Ceratophyllus acutus] 160, 161 mori. (Bombyx) 19, 47, 48, 53, $54,56,57,65,66,70,80$, $82,84,85,90,104,123$, $124,132,133,135,136,140$ $141,143,148,151,178,180$ 181

mori (Sericaria) 64 moubata (Ornithodoros) 6, 22, $68,70,86,143,144,154$, 155

muricatus (Tmetis) 178 musculi (Leptopsylia) 160, 161

museorum (Anthrenus) 43 nearcticus (A\&des) 163, 165 nemoralis (Neurotoma) 15,

$71,107,148,149$ Nepa sp., 180, 181 neustria (Malacosoma) 59, 183 niger var. americanus (Lasius) 118

nigrofaciatus (Oedalens) 178, 179 nigrovittatus (Tabanus) 43 
nigrum (Desmometopam) 18

nitida (Allorrhina [Cotinis]) 78,149

noctifer (Chrysops) 163, 164 Notonecta sp., 180, 181 novemnotata (Coccinella) 116, 124,150

nuba (Wohlfahrtia) 24 nubilalis (Pyrausta) 50, 58, $72,76,84,87,88,95,96$, 97, 99, 100, 102, 103, 108, $110,111,113,114,132$, $133,135,145,175,181$, 182,183

obesa (Volucella) 36, 37 occidentalis (Dermacentor)

$163,164,165,167$

ochracea (Gortyna) 58 ochrogaster (Euxoa) 71, 72 oleae (Dacus) 5, 10, 11, 18,

170,178

oleracea (Mamestra) 101, 102 oleracea (Polia) 41, 42 oregonensis (Melanotus) 118 orientalis (Anomala) 78 orientalis (Blatta [Periplaneta ]) 33, 49, 53, 124, $127,132,154,155,156$, $163,165,177,180,181$ orientalis (Ctenophthalmus)

163,165 ornata (Eurydema) 180, 181 ornithogallis (Prodenia) 71 orthogonia (Porosagrotis)

71

Osmoderma, 20

pallidefulva subsp. schau-

fussi var. incerta

(Formica) 118

pallinervis (Sarcophaga)

36,37

paranensis (Schistocerca)

178, 179

parkeri (Ornithodoros)

$163,165,166$ parumapertus [marginatus ]

(Dermacentor) 163, 164 peculiaris (Tabanus) 163 pellio (Attagenus) 43 pennsylvanica (Epicauta) 123,176 pennsylvanicus (Photuris) 127

Pentatomidae sp., 122 peregrina (Schistocerca)

178, 179

persicus (Argas) 6, 22, 23,

$27,43,44,68,70,86$,

$87,143,144,154,155$,

$157,160,161$

petroli (Psilopa) 6

phaeorrhea (Nygmia) 59

Phyllophaga [Lachnosterna ]

spp. , 149, 172

piceus (Attagenus) 118

Pieris spp., 76

piniperda (Trachea) 69

pipiens (Culex) 160

pityocampa (Cnethocampa)

109, 110, 143

plumosus (Chironomus) 17,

116

Polistes sp., 118

politus (Plagiognathus)

118

pollex (Ctenophthalmus)

163,165

polychlorus (Vanessa) 14,

45, 56, 109

pomi (Aphis) 118

pomonella (Carpocapsa) 118

pomonella (Rhagoletis) Il,

26,169

Potosia, 20

pratensis (Lygus) 86, 112 ,

118

prodenialis (Melitara) 120 prolixus (Rhodnius) 21, 22,

$31,68,70,86,154,155$ pronubana (Agrotia) 148, 149 Protoparce sp. 55

Ptinus, 43

pudibunda (Orgyia) 70, 89

pulicaria (Chaetocnema) 172 punctiventris (Bothynoderes) 
punctulatus (Crytocercus) 86 pyralis (Photinus) 173

quinquefasciatus (Culex) 12,16

quinquemaculata (Protoparce

[Phlegothontius]) 85

Ranatra sp., 180, 181 rapae (Pieris) 40, 101, 115, $122,123,151,154$ rapidus (Adelphocoris) 118 reflexus (Argas) 155 regina (Phormia) 24 relictus (Chrysons) 163 ricinus californicus

(Ixodes) 163, 165, 166 rubidus (Tabanus) 43 rugosa (Phyllophaga) $78^{\circ}$ rugulosus (scolytus) 118 rumicis (Aphis) 61, 62 rupestris (Tabanus) 163, 164

sabulosum (Opartum) 180, 181

salicis (Stilpnotia [Liparis]) $45,63,68,95,111,114$, 152

sanguineus (Rhipicephalus)

163,164

sanguinolenta (Chrysomela)

180,181

sayi (Psorophora [Janthinosoma ]) 43

scabei (Sarcoptes) 36 schaufussi var. incerta, pallidefulva (Formica) 118 schulzei (Rhipicephalus) 160, 161

segetum (Euxoa [Arrotis])

14, 40, 93, 94, 104, 107, 108, 109, 115, 122, 148, $149,153,173,185$ septentrionalis (Tabanus) 163,164 sericata (Lucilia) -6, 21, $24,63,118,119,157$, 158 serratus (Polyplax) 163,

164,166

sertifer (Diprion) 82, 83

sexdens (Atta) 178

sexta (Protoparce

[Phlegothontius]) 85

silantievi (Oropsylia

[Ceratophylius]) 160, 161 silvarum (Dermacentor) 160, $161,162,163,165$

simplex (Cediopsylla) 163,

165

smithi (Lachnosterna

[Phytalus]) 74, 75 sollicitans (Ä̈des) 12 solstitialis (Tabanus) 163 sordidus (Encoptolopus) 77 soror (Diabrotica) 118

stabulans (Muscina) 118, 158 stimulans (Akdes) 163, 165 strepens (Epacromia) 180, 181 striatus (Tabanus) 43 subspinosus (Macrodactylus) 78

sylvestris (Aldaes) 43

syringella (Gracilaria) 19

Tabanus sp. near nigrovittatus, 43

tarsalis (Culex) 163, 165 tenax (Eristalis) 174 Termites, 81, 82, 117 tesquorum (Ceratophyllus)

160,161

Tettigonidae sp., 144 Tipula sp., 56 trichodactyla (Hylemyia) 120

tristis (Anasa) 8, 55 trivittatus (Leptocoris) 55 turicata (Ornithodoros) 163, 165,166

turkestanica. (Chrysozona) 163

turkestanus (Tabanus) 163

unipuncta (Cirphis) 141, 142

urticae (Vanessa) 14, 45, 54, 
$57,59,63,64,65,66$, $69,83,87,95,104,109$, $111,114,136,137,152$, 183,184 utanus (Strategus) 149

vandinei (Lachnosterna)

Phyllophaga, 149 variabilis (Dermacentor)

163,165

variegata (Loxa) 122, 128 ventricosus (Haemodipsus)

$163,164,166$ verbasci (Campylomma) 118
Vespula sp. , 118 vexans (Aldes) 12, 163, 165

viridissima (Locusta) 154 vittata (Diabrotica) 121, 122

volgense (Hyalomma) 160, 162

vomitoria (Calliphora) 17, $18,26,174$

vomitoria (Chlorops) 36 vulgaris (Melolontha) 104, 180,181 vulpinus (Dermestes) 43, 44 


\section{INDEX TO BACTERIA}

A (Bacillus) Ledingham, 39

A (Bacillus) White, 5, 39 abortus (Brucella) 22, 158 Achromobacter, 92 acidificum (Flavobacterium)

115

acidiformans (Bacterium) 95 acridicida (Micrococcus) 144 acridicida (Staphylococcus)

144,154

acridiorum (Coccobacillus)

66, 77, 78, 79, 178, 179,

180

acridiorum "Souchi Cham"

(Coccobacillus) 179 acridiorum "Souchi Sidi"

(Coccobacillus) 179 adiposus, lymantricola

(Bacillus) 64

adiposus, lymantricola (Bac-

terium) 14, 104

aegyptius, (Bacillus) 40,

97, 159

aerifaciens (Bacillus) 40

Aerobacter, 122

aerogenes (Aerobacter) 17,

60,122

aerogenes, lactis (Bacillus)

122

aeruginosa (Pseudomonas) 7, 9,

$17,80,172$

agalactiae (Streptococcus)

138,139

agilis (Bacillus) 40, 60

agilis, pieris (Bacillus) 75

agrotidis typhoides (Bacil-

Ius) 40

alacer (Bacillus) 41

albolactis (Bacillus) 41

albus (Staphylococcus) 9, 22,

154,155

Alcaligenes, 176

alvei (Bacillus) 13, 26, 41,

$42,49,68,69,77,92$,

93,139

alveicola (Proteus) 97, 126

alvei, paratyphi (Bacillus) alveolaris (Bacillus) 43 ammoniagenes (Alcaligenes) 176

amylovora (Erwinia) 118, 119,144

amylovorus (Micrococcus)

119,144

anthracis (Bacillus) 7, 22, 43,44

apis (Streptococcus) 13,

$41,42,77,93,139,142$ apiseptious (Bacillus) 45 apium, coli (Bacterium)

97, 126

aroideae (Erwinia) 120

Ascobacterium, 178

aurantiaca (Sarcina) 153

aureus (Bacillus) 45

aureus (Staphylococcus) 9,

22, 25, 152, 154, 155,

156,157

B (Bacillus) Hofmann, 45, 69,105

B (Bacillus) White, 46

Bacillus, 39

Bacterium, 94

Bacterium sp., 94

barbitistes (Bacillus) 46

blattelae (Corynebacterium)

33

bombycis (Aerobacter) 95,

123,126

bombycis (Bacillus) Chatton, 47

bombycis (Bacillus)

Macchiate, 47

bombycis (Bacillus) Pasteur, 47

bombycis (Bacterium) 47, 95 bombycis (Diplococcus) 136 bombycis (Proteus) 123, 126 bombycis (Streptococcus)

$140,141,143,148$ bombycis non-liquefaciens

(Bacillus) 47

bombycivorum (Bacterium)

95,123 
bombysepticus (Bacillus) 48 botulinum Type C (Clostridium)

$$
\text { 90, } 91
$$

brandenburgiensis (Bacillus)

$$
48,60,61
$$

bronchisepticus (Alcaligenes)

$$
176
$$

Brucella, 158

buccalis (Leptotrichia) 33, 186 buccalis (Leptotrix) 33, 186 burri (Bacillus) 48, 60,61 butlerovii (Bacillus) 49 butschlii (Bacillus) 49

C (Micrococcus) White 5, 144 cacticida (Erwinia) 49, 120 cacticidus (Bacillus) 49, 120 cajae (Bacillus) 49, 52, 181 cajae (Coccobacillus) 49, 180,181

campestris (Bacillus) 50, 168 campestris (Phytomonas) 50, 168

canadensis (Bacillus) 50 canadensis (Bacterium) 50, 95

canus (Bacillus) 50 capsulata (Klebsiella) 125 carotovora (Erwinia) 9, 10, $50,120,121$ carotovorus (Bacillus) 50, 120,121 catarrhalis (Micrococcus) 144,157 catarrhalis (Neisseria) 22, 144, 157

cazaubon (Bacterium) 95, 96 cazaubon I (Bacterium) 96 cazaubon II (Bacterium) 96 cellulosum (Bacterium) 96 cellulosam fermentans

(Bacillus) 20, 50, 91, 92 cereus (Bacillus) 41, 51, 55 chersonesia (Micrococcus) 144 chlorum (Flavobacterium) 116 cholerae suis (Bacillus) 51, 130,131 cholerae suis (Salmonella) $51,130,131$ christiei (Bacterium) 96 Chromobacterium, 177 circulans (Bacillus) 51 citreus (Enterococcus) 185 citreus (Staphylococcus) 156

cleoni (Bacillus) 51, 52 cloacae (Aerobacter) 52, 123

cloacae (Bacillus) 52, 123 Clostridium, 90 Coccobacillus, 178 coeruleus (Bacillus) 52 coli (Bacillus) 21, 29, 52 coli (Bacterium) 97, 124 coli (Escherichia) 17, 21, $52,97,124$ coli apium (Bacterium) 97, 126

coli communis (Bacillus)

52,124

comma (Vibrio) 15, 174, 175 conglomeratus (Micrococcus)

145

conjunctivitidis (Bacterium) 40, 97

Corynebacterium, 33

Corynebacterium sp., 33 cubonianus (Bacillus) 53 cuenoti (Bacillus) 53 cuniculicida (Bacillus) 53, 159 cuniculicida (Pasteurella) 53, 159

curtissi (Micrococcus) 145 cyaneus (Bacterium) 5, 98

D (Bacterium) White, 98 Danysz bacillus, 184 decolor (Bacillus) 54 delendae-muscae (Bacterium) 98 delicatulum (Achromobacter) 92, 93 devorans (Flavobacterium) 116 diphtheriae (Corynebacterium) 33,34 Diplobacillus, 134 
Diplococcus, 136

disparis (Streptococcus) 141 dobelli (Bacillus) 54 dobelli (Flexilis) 54 duplex (Hemophilus) 97, 159 duttoni (Spirochaeta) 23 dysenteriae (Shigella) 7, 9, 131

E (Bacillus) 54

Eberthella, 128

elbvibrionen (Bacterium)

99

Ellenbachi (Bacillus) 51, 54,55

ellingeri (Coccobacillus)

$107,113,124,181,182$ ellingeri (Escherichia) 124, 181,182 enteritidis (Salmonella) 7,

9, 131,184

Enterobacillus, 185

Enterococcus, 185

entomotoxicon (Bacillus) 55 ephestiae No. I (Bacterium)

99

ephestiae No. 2 (Bacterium)

99

ephestriae (Micrococcus)

145,146

epidermidis (Micrococcus)

146

equidistans (Bacillus) 55

Erwinia, 118

Escherichia, 124

eurydice (Achromobacter) 13,

$41,42,77,92,93$

euryaice (Bacterium) 13, 41,

$42,77,92,93,139$

faecalis (Streptococcus) 5, 22, 142

fecalis (Streptococcus)

see faecalis

fermentans (Flavobacterium)

116,172

fermentans (Pseudomonas) 17,

116,172

fermentans, cellulosam (Bacil-

lus) $20,50,91,92$ ferrugenus (Bacillus) 56

ferrugineus (Bacillus) 56

flaccidifex (Gyrococcus) 146,185

flaccidifex danai (Micrococcus) 146

flava (Sarcina) 153

Flavobacterium, 115

flavus (Bacillus) 56

flavus (Micrococcus) 147

Flexilis, 54

flexilis (Bacillus) 56

fluorescens (Pseudomonas)

10, 17, 172, 173

fluorescens liquefaciens

(Bacillus) 79

fluorescens liquefaciens

(Pseudomonas) 172, 173

fluorescens, pieris

(Bacillus) 75, 79, 184

fluorescens septicus

(Bacillus) 56, 173

foetidus (Bacillus) 57, 89

freudenreichii (Micro-

coccus) 147

freundii (Escherichia) 125

fuchsina (Serratia) 57,

132

fuchsinus (Bacillus) 57, 132

Fusiformis, 117

Fusobacterium, 117

galleriae (Bacterium) 99, 100

galleriae No. 2 (Bacterium) 100

gastricus (Bacillus) 57 gaytoni (Bacillus) 57

gelechiae No. I (Bacterium) 100,101

gelechiae No. 2 (Bacterium) 100,101

gelechiae No. 5 (Bacterium) 101

gibsoni (Bacillus) 58, 182 gibsoni (Coccobacillus) 58, 182

gigas (Bacillus) 58

gortynae (Bacillus) 58 
graphitosis (Bacillus) 58 graphitosis, tracheitis sive

(Bacillus) 59, 89

gryllotalpae (Bacillus) 59 gryllotalpae (Bacterium) 101 Gyrococcus, 185

haemolyticus (streptococcus) 22, 142,144

hebetisiccus (Bacterium) 101 Hemophilus, 159

hemophosphoreum (Bacterium)

101

hilli (Fusiformis) 118 hoplosternus (Bacillus) 59 hyalinum (Achromobacter) 93 hyalinum (Acromobacter) 93 hyalinus (Bacillus) 93

immobilis (Bacillus) 60 imperiale (Bacterium) 102 incertum (Bacterium) 103 insecticola (Eberthella) 5, 128

insecticolens (Proteus) 127 insectiphilium (Bacterium)

103

insectorum (Bacillus) 60,

147,148

insectorum (Micrococcus)

$60,147,148$

insectorum (Staphylococcus)

156

insectorum var. malacosomae

(Coccobacillus) 183

insectorum, septicus

(Bacillus) 83, 149

intrinsectum (Bacterium) 102

italicum No. 2 (Bacterium)

102

Klebsiella, 125

knipowitchii (Bacterium)

103

lactis aerogenes (Bacillus) 60,122

lanceolatus (Bacillus) 60 lardarius (Micrococcus) 148 larvae (Achromobacter) 93, 185

larvae (Bacillus) 48, 60, 61,90

larvae (Entero-bacillus) 93, 185

lasiocampa (Bacillus) 61 lathyri (Bacillus) 61, 62, 121

lathyri (Erwinia) 61, 62, 121

lentimorbus (Bacillus) 62, 78

leonardi (Vibrio) 175

leprae (Mycobacterium) 36, 37

leptinotarse (Bacillus) 62 Leptotrichia, 33

Leptotrix, 33

lineatus (Bacillus) 57, 63 liparis (Bacillus) 15, 63 liparis (Diplococcus) 136 liquefaciens (Streptoccus) 139,142

liquefaciens, fluorescens

(Pseudomonas) 172, 173

Listerella, 103

Listeria, 103

lophyri, septicaemiae

(Bacillus) 82

luciliae (Clostridium) 91

luciliarum (Neisseria) 63,

157

lutea (Sarcina) 17, 153

luteum (Ascobacterium) 10, 170,178

luteum (Bacteridium) 178

luteum (Bacterium) 178

luteus (Micrococcus) 178

lutzae (Bacillus) 63, 152, 158

lymantriae (Bacillus) 64, $104,136,137,183$

lymantriae alpha (Bacillus) 64

lymantriae beta (Bacillus) 64

Iymantriae (Bacterium) 64, 104, 137, 183 
lymantriae (Coccobacillus)

$64,136,137,183$

lymantriae (Diplococcus)

$136,137,183$

lymantricola adiposus

(Bacillus) 64

lymantricola adiposus

(Bacterium) 14, 104

major (Micrococcus) 148

marcescens (Serratia) 7, 22,

$78,94,110,130,132,133$,

134,135

maris (Flavobacterium) 117

medicaginis var. phaseolicola

(Phytomonas) 168

megatherium (Bacillus) 65,

83, 95

megaterium bombycis (Bacillus)

65

melolonthae (Bacillus) 66

melolonthae (Diplobacillus)

137,184

melolonthae liquefaciens

alpha (Bacillus) 66, 67

melolonthae liquefaciens

beta (Bacillus) 66, 67 melolonthae liquefaciens gamma (Bacillus) 66, 67 melolonthae liquefaciens

(Bacterium) 104 melolonthae liquefaciens

alpha (Bacterium) 182 melolonthae liquefaciens gamma (Bacterium) 14, 104 melolonthae non-liquefaciens alpha (Bacillus) 67, 68 melolonthae non-liquefaciens

beta (Bacillus) 67 melolonthae non-liquefaciens gamma (Bacillus) 67 melolonthae non-liquefaciens delta (Bacillus) 68 melolonthae non-liquefaciens epsilon (Bacillus) 68 melophthora (Phytomonas) 25, 169 mesentericus (Bacillus) 22, $39,68,90,153$ Micrococcus, 144 millii (Bacillus) 68, 69

minimus (Bacillus) 69

minutiferula (Bacterium) 104 monachae (Bacillus) 69, 105

monachae (Bacterium) 45,

46, 69, 105

monocytogenes (Listerella)

103

muscae (Staphylococcus)

157

mutabile (Bacterium) 15, 106 Mycobacterium, 36

mycoides (Bacillus) 17, 22,

70,106

mycoides (Bacterium) 70, 106

Neisseria, 157

neopolitanum (Bacterium)

94,106

neurotomae (Bacillus) 71,

107

neurotomae (Bacterium) 15,

71,107

neurotomae (Micrococcus)

148

nigrofaciens (Micrococcus)

83, 149

nitrificans (Micrococcus)

150

noctuarii (Escherichia) 71 ,

125

noctuarum (Bacillus) 62, 71,

$85,107,125,127$

noctuarum (Bacterium) 107,

182

noctuarum (Proteus) 71, 127 nonfermentans (Micrococcus)

150

non-liquefaciens (Bacillus)

67,75

non-liquefaciens (Pseudomonas)

10

oblongus (Bacillus) 72

ochraceum (Bacillus) 72, 108 ochraceum (Bacterium) 72,

107, 108, 117

ochraceum (Flavobacterium)

108, 117

ochraceus (Micrococcus) 150 
ontarioni (Bacillus) 72, 108

ontarioni (Bacterium) 72, 97, 108

orpheus (Bacillus) 72 ovalis (Pseudomonas) 173 ovatus (Micrococcus) 151

Pasteurella, 159 paracoli (Bacterium) 108 paralvei (Bacillus) 72 paralytica (Klebsiella) 125, 126

paratyphi (Bacterium) 109, 131

paratyphi (Salmonella)

73, 109, 131 paratyphi alvei (Bacillus) 73, 131 parvula (Veillonella) 15i, 158

parvulus (Micrococcus) 151, 157

parvulus (Staphylococcus) 151, 157

pastorianus (Streptococcus) $140,141,143$ paurometabolum (Corynebacterium) 34, 35 pectinophorae (Bacillus) 74 pediculi (Bacillus) 74 pemphigocontagiosus (Diplococcus) 137

perflava (Neisseria) 158 periplantae var. americana

(Corynebacterium) 33, 35 pestis (Bacillus) 74, 75, 160

pestis (Pasteurella) 22,

$75,160,161,162$

photuris (Proteus) 127

Phytomonas, 168

pieridis (Micrococcus) 151

pieris (Diplococcus) 75, 138 piexis (Diplobacillus) 75, 184

pieris (Vibrio) 176 pieris agilis (Bacillus) 75 pieris fluorescens (Bacillus)

$75,79,184$ pieris liquefaciens alpha

(Bacillus) 75, 76 pieris liquefaciens beta

(Bacillus) 75, 76 pieris liquefaciens alpha

(Bacterium) 14, 15, 109 pieris non-liquefaciens

alpha (Bacillus) 75, 76 pieris non-liquefaciens

beta (Bacillus) 75, 76 pirenei (Bacillus) 76 pityocampae (Bacterium) 109, 142 pityocampae alpha (Streptococcus) 109, 142 pityocampae beta

(Streptococcus) 109, 142 pluton (Bacillus) 13, 41, 42, 77, 90, 92, 93, 138, 139 pluton (Diplococcus) 138 plymouthensis (Serratia) 135 Pneumococco, 186 pneumoniae (Diplococcus) 186 poncei (Bacillus) 77

popilliae (Bacillus) 78 prodeniae (Bacterium) 110 prodigiosum (Bacterium)

$110,133,134,135$ prodigiosus (Bacillus) 78 ,

$80,132,133,135$ prodigiosus (Bacterium)

110,134

proteidis (Bacillus) 75, 79

Proteus, 126

proteus (Bacillus) 79

pseudotsugae (Bacterium)

110,169

pseudotsugae (Phytomonas)

110,169

pseudoxerosis (Bacillus) 79

Pseudomonas, 172

punctatus (Bacillus) 79

pyocyaneus (Bacillus) 80, 172

pyogenes (Eberthella) 128 pyogenes (Staphylococcus) 154

pyogenes (Streptococcus) $142,143,144$

pyogenes aureus (Micrococcus) 152,155 
pyogenes aureus (Staphylococcus ) 155,157

pyrameis I (Bacillus) 81 pyrameis II (Bacillus) 81 pyraustae Nos. 1-7 (Bacterium)

110

pyrenei (Bacterium) 76, 111 pyrenei No. I (Bacterium)

111,112

pyrenei NNo. 2 (Bacterium)

111,112

pyrenei No. 3 (Bacterium)

111, 112

qualis (Bacterium) 112

recticolens (Proteus) 5, 127 rheni (Flavabacterium) 117 rickettsiformis (Bacillus) 81

rotans (Bacillus) 81,82 rubefaciens (Bacillus) 82 rubrum (Bacterium) 112 rushmori (Micrococcus) 63, 152

saliciperda (Phytomonas)

170,173

saliciperda (Pseudomonas)

170,173

Salmonella, 130

salutarius (Bacillus) 82 Sarcina, 153 savastanoi (Bacterium)

$112,170,171$ savastanoi (Phytomonas)

$10,112,170,171$ sch8ttmulleri var. alve1

(Salmonella) 73, 131 septica (Pseudomonas) 56,

173,174 septicaemiae lophyri

(Bacillus) 82 septicus, fluorescens

(Bacillus) 56, 173 septieus insectorum

(Bacillus) 83, 149 Serratia, 132 Shigella, 131 similis (Bacillus) 57, 83 solanacearum (Bacillus) 84,171

solanacearum (Phytomonas)

84,171

sotto (Bacillus) 84, 112

sotto (Bacterium) 84, 112 spermatozoides (Bacillus) 85 sphingidis (Bacillus) 62, 71,

$85,113,125,127$ sphingidis (Bacterium) 107,

113,182

sphingidis (Escherichia) 125

sphingidis (Proteus) 127

Staphylococcus, 154

stevensae (Alcaligenes) 6I, 176

stewarti (Phytomonas) 172

Streptococcus, 138

subflavus (Micrococcus) 152 subgastricus (Bacillus) 57,

85,86

subtilis (Bacillus) 17, 22,

70,86

superficiale (Achromobacter)

94

tegumenticola (Bacterium) 113 tenax (Bacillus) 87

termitidis (Fusiformis) 117, 118

termo (Bacterium) 113

tetani (Clostridium) 91

thuringiensis (Bacillus) 87, $88,95,99,114$

thuringiensis (Bacterium)

$88,89,114$

thuringiensis No. 1 (Bacterium) 88,114

thuringiensis No. 2 (Bacterium) 88,114

tingens (Bacillus) 89

tracheiphila (Erwinia) 89,

121

tracheiphilus (Bacillus)

89, 122

tracheitis sive graphitosis

(Bacillus) 59, 89

tuberculosis (Mycobacterium) 38 


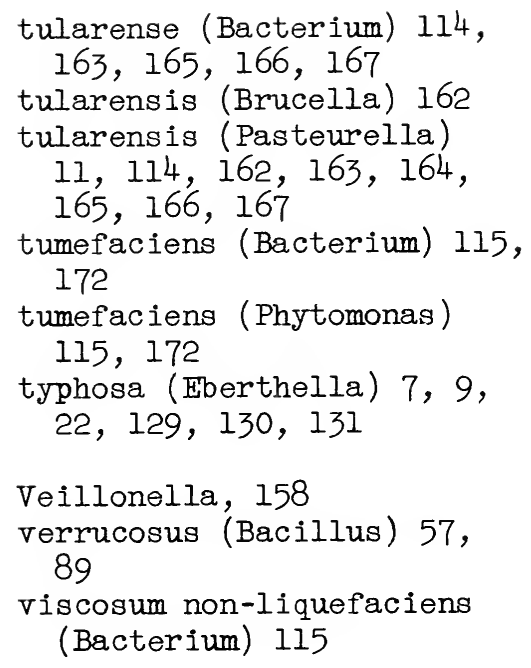

Vibrio, 174

violaceum (Chromobacterium) 90,177

violaceus (Bacillus) 90, 177

viridans (Bacillus) 90

vulgaris (Micrococcus) 152

vulgaris (Proteus) 79, 113, 127, 128

vulgatus (Bacillus) 22, 68, 90

welchii (Clostridium) 25 werneri (Clostridium) 50, 91

X (Bacillus) White, 61, 90

Y (Bacillus) White 90 


